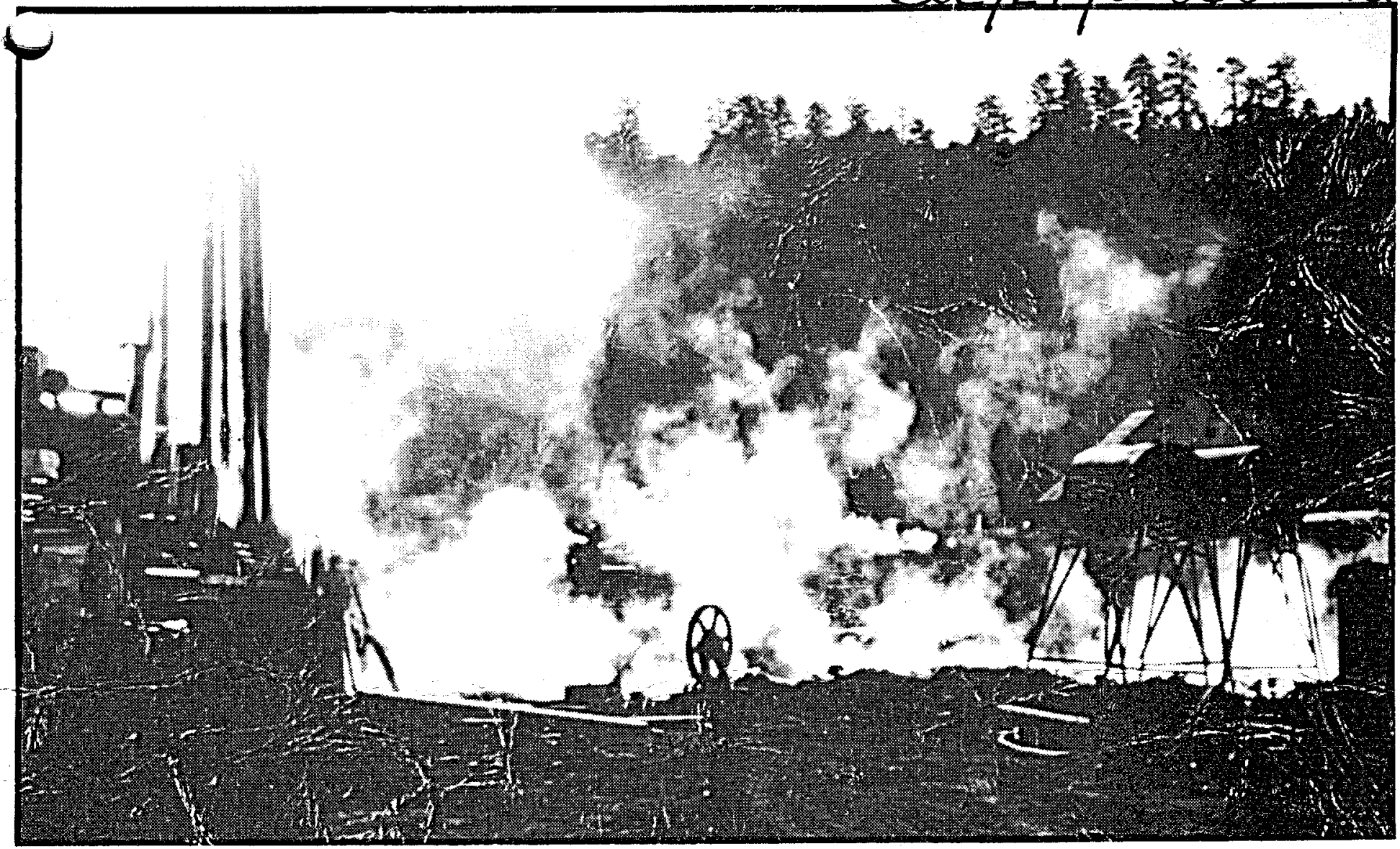

\title{
COLORADO'S HYDROTHERMAL RESOURCE BASE- AN ASSESSMENT
}

by Richard Howard Pearl

COLORADO GEOLOGICAL SURVEY DEPARTMENT OF NATURAL RESOURCES DENVER, COLORADO

\section{MASTER}

1979

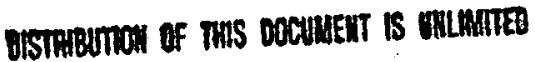




\section{DISCLAIMER}

This report was prepared as an account of work sponsored by an agency of the United States Government. Neither the United States Government nor any agency Thereof, nor any of their employees, makes any warranty, express or implied, or assumes any legal liability or responsibility for the accuracy, completeness, or usefulness of any information, apparatus, product, or process disclosed, or represents that its use would not infringe privately owned rights. Reference herein to any specific commercial product, process, or service by trade name, trademark, manufacturer, or otherwise does not necessarily constitute or imply its endorsement, recommendation, or favoring by the United States Government or any agency thereof. The views and opinions of authors expressed herein do not necessarily state or reflect those of the United States Government or any agency thereof. 


\section{DISCLAIMER}

Portions of this document may be illegible in electronic image products. Images are produced from the best available original document. 


\section{NOTICE}

This report was prepared to document work sponsored by the United States Government. Neither the United States nor its agent, the United States Department of Energy, nor any Federal employees, nor any of their contractors, subcontractors or their employees, makes any warranty, express or implied, or assumes any legal liability or responsibility for the accuracy, completeness, or usefulness of any information, apparatus, product or process disclosed, or represents that its use would not infringe privately owned rights.

\section{NOTICE}

Reference to a company or product name does not imply approval or recommendation of the product by the Colorado Geological Survey or the U.S. Department of Energy to the exclusion of others that may be suitable.

Cover: Photo taken during drilling of Pagosa Springs geothermal well, photo by Michael Galloway. 


$$
\text { DOE/ET/28365- T2 }
$$

\section{COLORADQ'S HYDROTHERMAL RESOURCE BASE AN ASSESSMENT by \\ RICHARD HOWARD PEARL}

$\mathrm{DOE} / \mathrm{ET} / 28365--\mathrm{T} 2$

DE83 006663

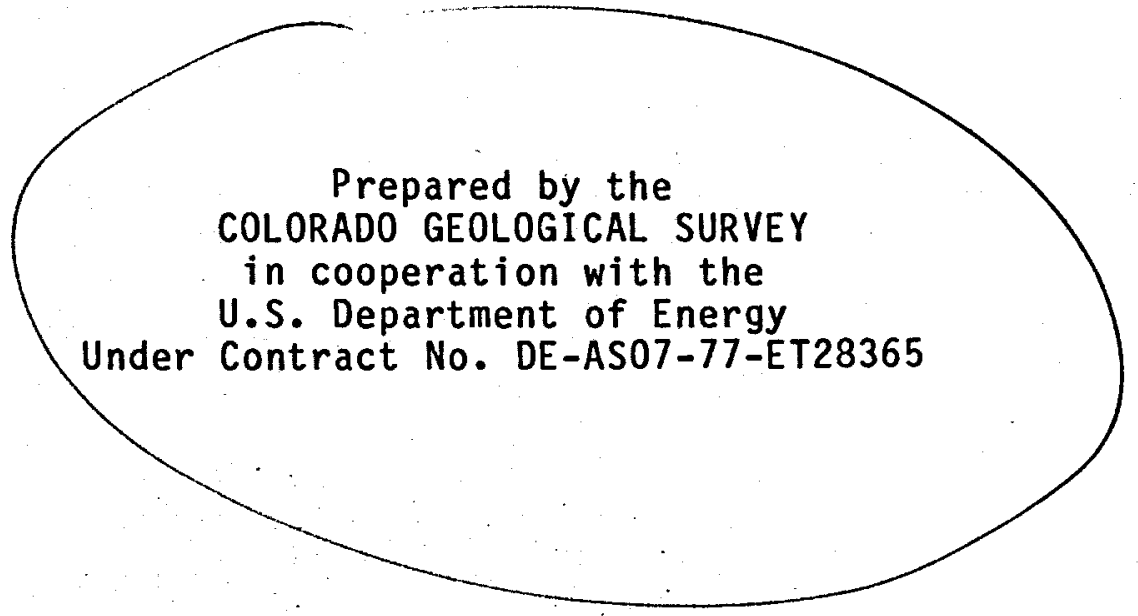

COLORADO GEOLOGICAL SURVEY

DEPARTMENT OF NATURAL RESOURCES

STATE OF COLORADO

Denver, Colorado

\section{9}

$\$ 6.00$

\section{NOTICE}

PORTIONS OF THIS REPORT ARE ILLEGIBLE. It

has been reproduced from the best available copy to permit the broadest possible availability. 


\section{CONTENTS}

PAGE

Abstract.......................................... 1

Introduction........................................

Geothermometer models theory and examples................... 2

Silica geothermometer models.......................... 4

Quartz-silica geothermometer.......................... 4

Amorphous silica, chalcedony, and cristobalite

si] ica geothermometers.............................

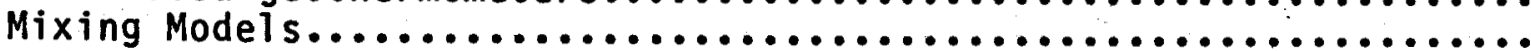

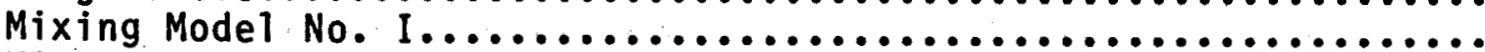

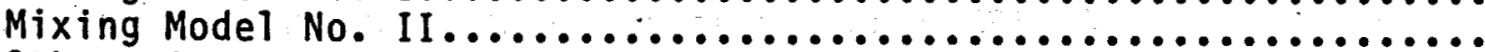

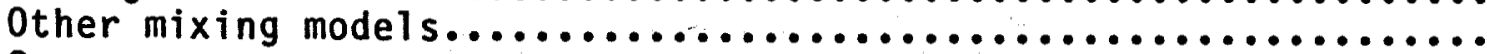

Summary.........................................

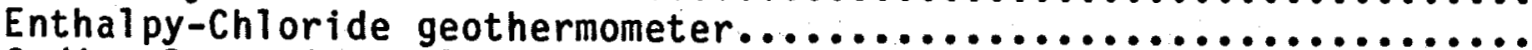

Sodium-Potassium-Calcium Geothermometer Model ...................

Sodium-Potassium Geothermometer Model ........................

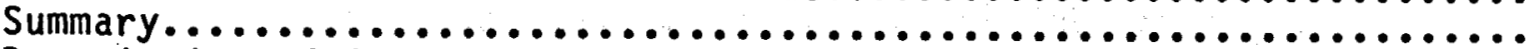

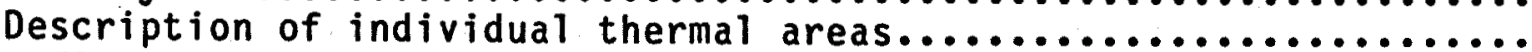

\#1 Juniper Hot Springs.................................

Location......................................

General ......................................

Geology and hydrology.............................

Geothermometer analyses............................

Resource assessment...............................

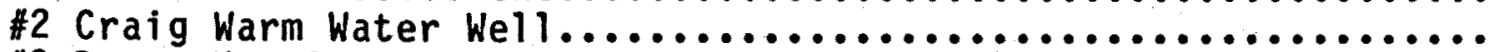

\#3 Routt Hot Springs..................................

\#4 Steamboat Springs................................

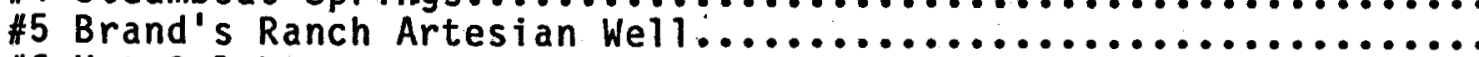

\#6 Hot Sulphur Springs..................................

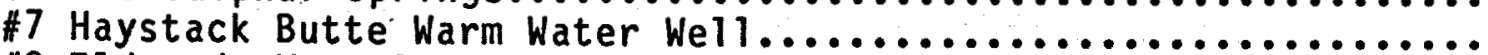

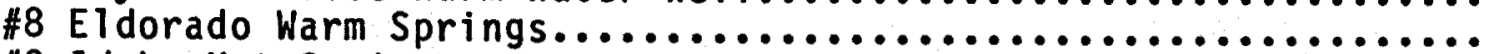

\#9 Idaho Hot Springs.................................

\#10 Dotsero Warm Springs................................

\#11 Glenwood Hot Springs.............................

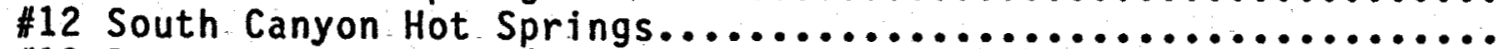

\#13 Penny Hot Springs (Avalanche Hot Springs) ..................

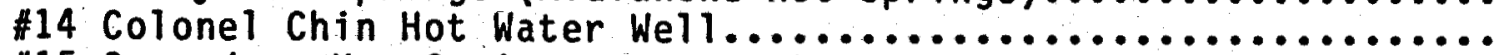

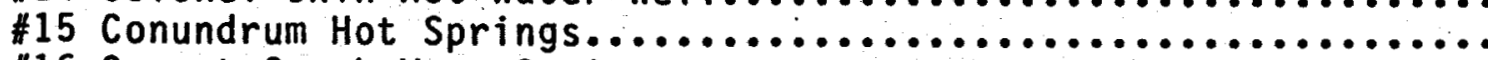

$\# 16$ Cement Creek Warm Spring............................

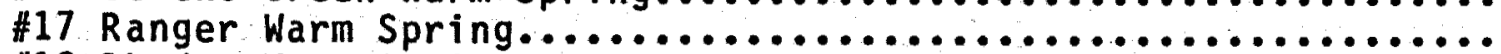

\#18 Rhodes Warm Spring...............................

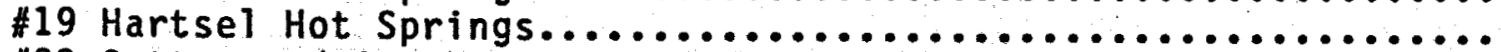

\#20 Cottonwood Creek

Cottonwood and Jump Steady Hot Springs................ 47

\#21 Chalk Creek Area................................... 49

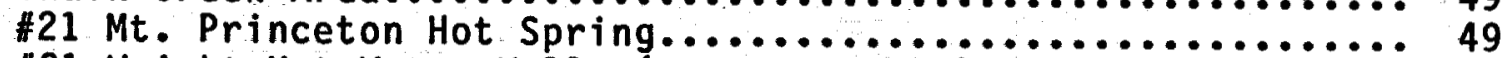

\#21 Wright Hot Water Wells (East and West) ...................... 49

\#21 Hortense Hot Spring and Well and Young Life

Hot Water Well................................

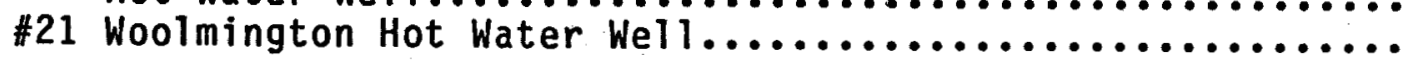


\#22 Brown's Canyon Thermal Area.......................... 53

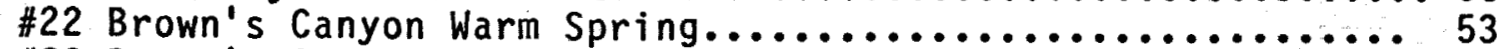

\#22 Brown's Grotto Warm Spring.......................... 53

\#22 Chimney Hill Warm Water Well..................... 53

\#23 Poncha Hot Springs................................ 55

\#24 Wellsville Warm Springs........................... 59

\#25 Swissvale Warm Springs.............................. 60

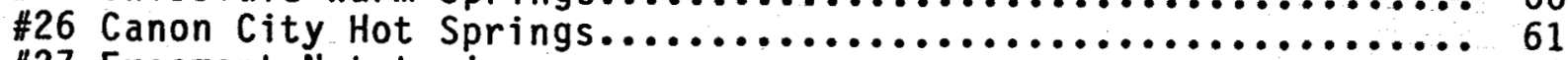

\#27 Freemont Natatorium............................ 63

\#28 Penrose Artesian Well (Florence Artesian Weii)...............65

\#29 Don $K$ Ranch Artesian Wel1.......................... 67

\#30 Clark Artesian Well(clark Spring Warm Water Weili).......... 69

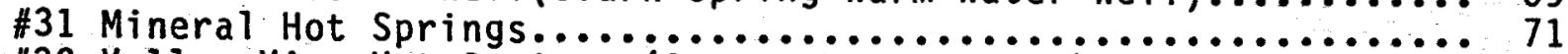

\#32 Valley View Hot Springs (Orient Hot Springs) .............. 74

\#33 Shaws Warm Spring.............................. 76

\#34 Sand Dunes Swimming Pool Hot Water Wel1 ............... 78

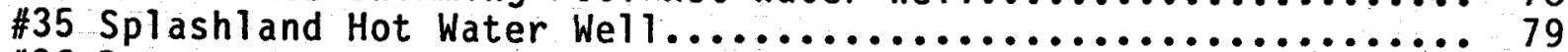

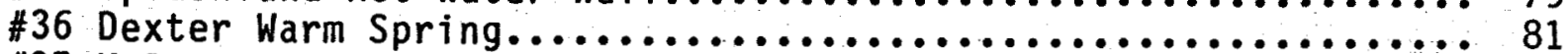

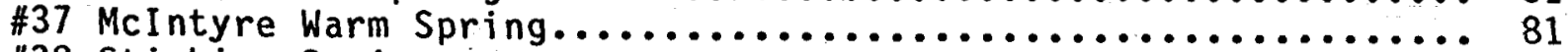

\#38 Stinking Springs................................. 83

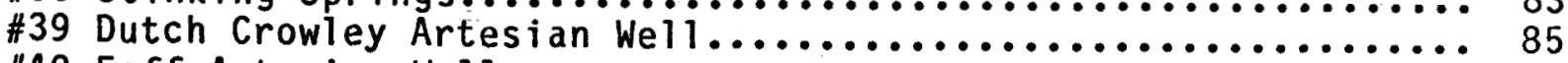

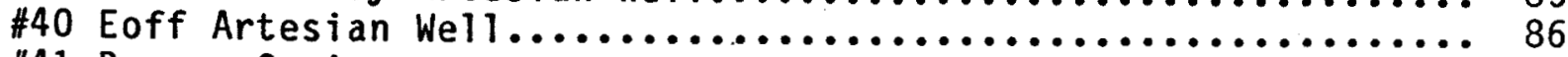

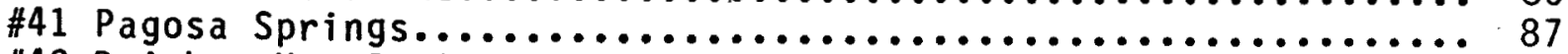

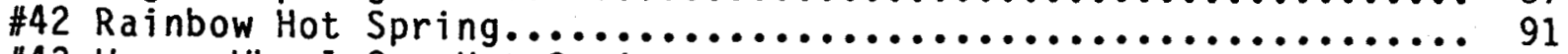

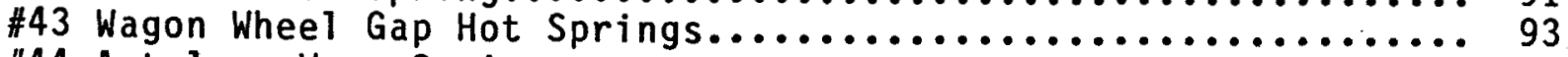

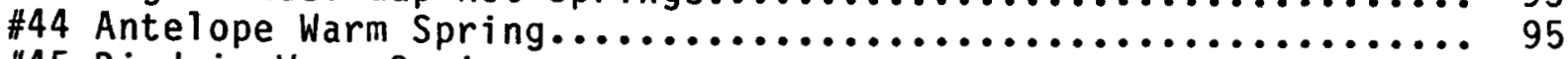

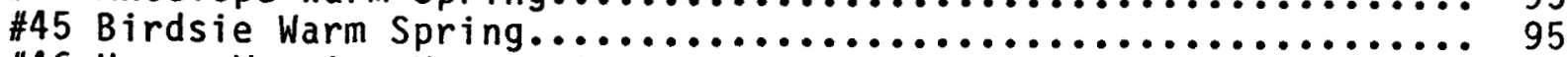

\#46 Upper Waunita Hot Springs .......................... 99

\#46 Lower Waunita Hot Springs........................... 99

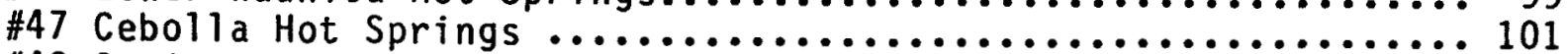

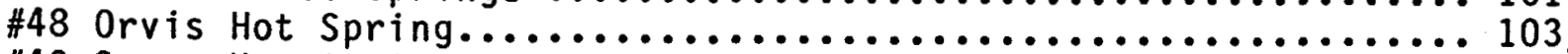

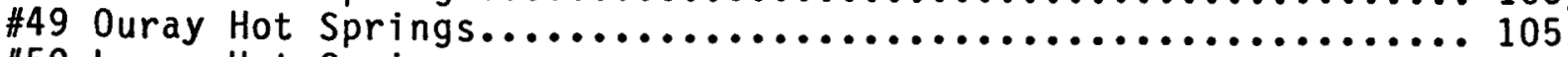

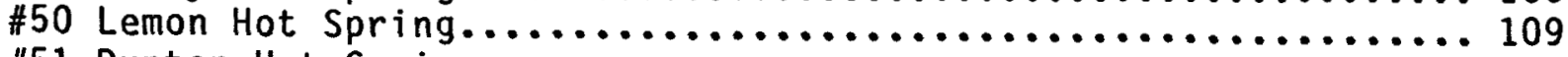

$\# 51$ Dunton Hot Spring $\ldots \ldots \ldots \ldots \ldots \ldots \ldots \ldots \ldots \ldots \ldots \ldots \ldots \ldots \ldots \ldots \ldots \ldots \ldots \ldots 10 \ldots \ldots$

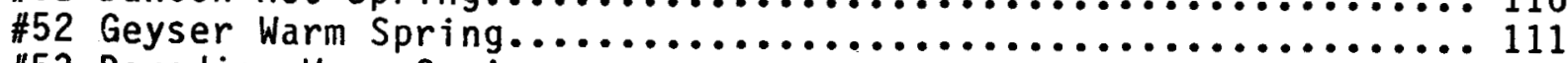

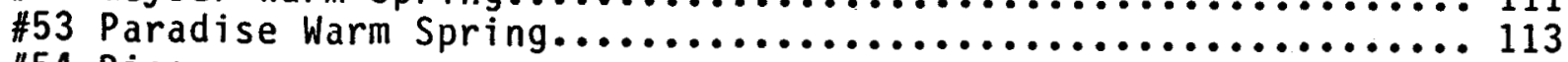

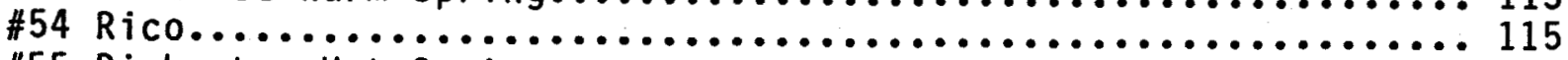

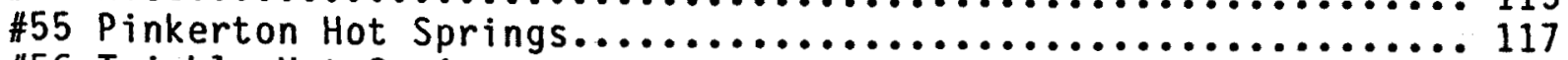

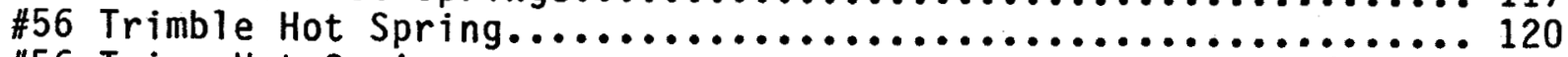

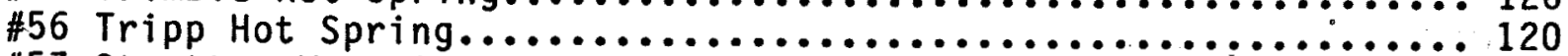

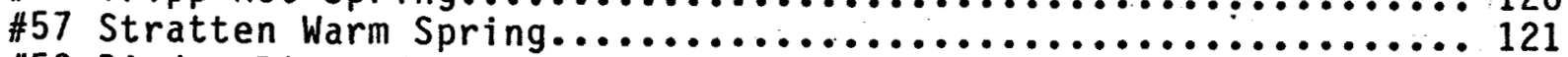

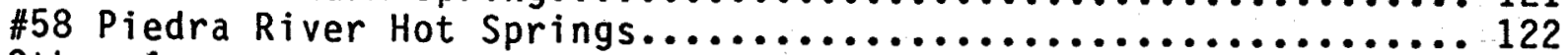

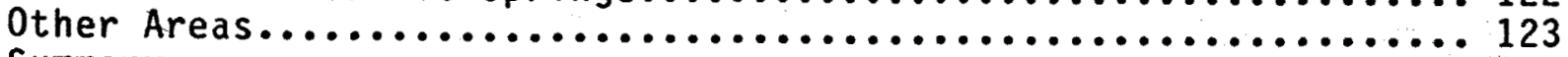

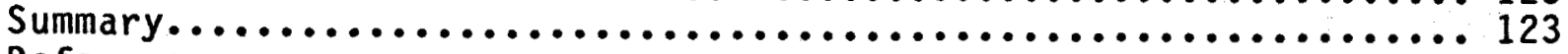

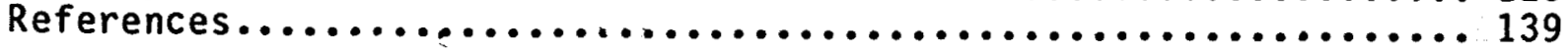




\section{FIGURES}

PAGE

1 Location of thermal springs and wells

in Colorado.................................... 3

2 Spring location numbering system used in colorado..........

3 Geologic map of Juniper Hot Springs area and areal

extent of assumed geothermal reservoir.................

Map showing geology surrounding Criag Warm Water Well

and areal extent of assumed geothermal reservoir...........

Geology of Routt and Steamboat Springs and extent of

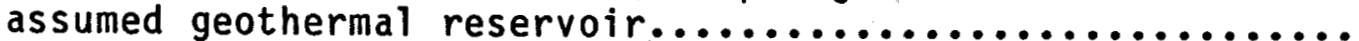

Geology of Brands Ranch Artesian Well and extent

of assumed geothermal reservoir......................

7 Map showing geologic conditions surrounding Hot Sulphur

Springs and assumed extent of geothermal reservoir........

Geology of Haystack Butte area and assumed areal

extent of the geothermal reservoir....................

9 Map showing the assumed areal extent of the geothermal

reservoir and the geologic conditions surrounding

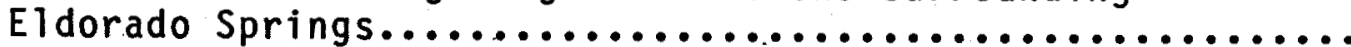

Geology surrounding Idaho Springs and assumed geothermal

11 Map showing assumed areal extent of the geothermal

reservoir and geologic conditions surrounding Dotsero

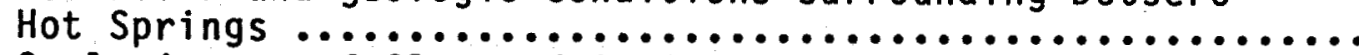

Geologic map of Glenwood Springs and surrounding region

and assumed areal extent of the geothermal reservoir.......

Map showing assumed extent of the South Canyon Hot Springs

geothermal reservoir and the surrounding geology...........

14 Penny Hot Springs, geology and assumed areal extent of

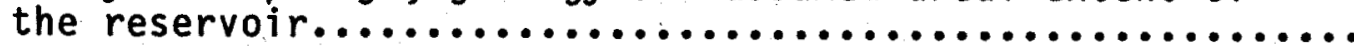

15 Map showing geologic conditions surrounding Colonel Chinn Water Well and assumed areal extent of the reservoir......

16 Map showing assumed areal extent of the Conundrum Hot Springs reservoir and surrounding geologic conditions.....

17 Map of Cement Creek and Ranger Warm Springs showing assumed areal extent of the geothermal reservoir...........

18 Rhodes Warm Spring, geology of surrounding area and assumed areal extent of the geothermal reservoir...........

19 Map showing assumed areal extent of the Hartsel Hot Springs geothermal reservoir and geology of surrounding

20 Geologic map of region surrounding cottonwood creek and Chalk Creek valleys and asumed areal extent of the

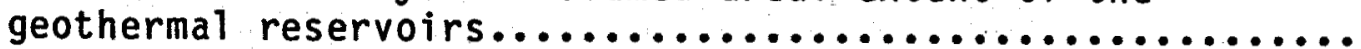

21 Map showing assumed areal extent of the Browns Canyon geothermal reservoir and geology of surrounding region..... Map showing geologic conditions surrounding Poncha Hot Springs and assumed areal extent of the geothermal springs. 


\section{FIGURES (Cont.)}

24 Geology of Canon City region and assumed areal extent

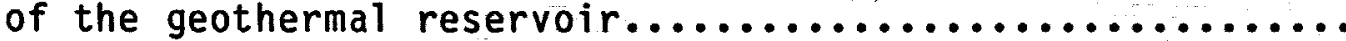
Map showing assumed areal extent of the Fremont Natatorium geothermal reservoir and surrounding geologic conditions... Geology of the Florence area and assumed areal extent of the Penrose Artesian well geothermal reservoir.............. Don K Ranch area, geology and assumed areal extent of

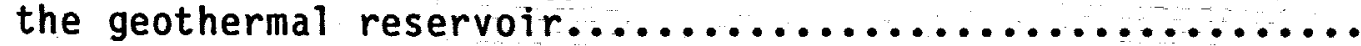

28 Map showing assumed areal extent of the Clark Artesian Well geothermal reservoir and surrounding geologic

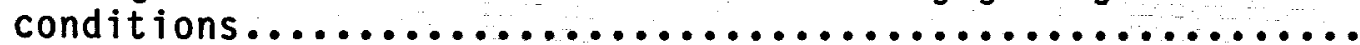
Map of geologic conditons surrounding Mineral Hot Springs and assumed areal extent of the geothermal reservoir....... Valley View Hot Springs area, geology and assumed areal

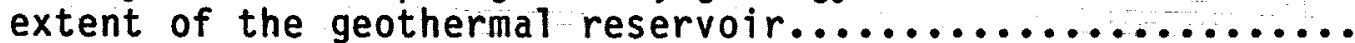
Geology and assumed areal extent of the geothermal

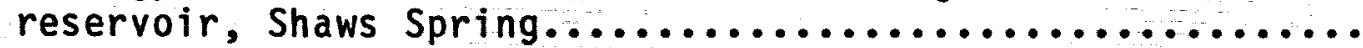
Map showing assumed areal extent of the Dexter and McIntyre Warm Springs geothermal reservoir and surrounding area...... Map of Stinking Springs and Dutch. Crowley Artestian Well region showing geology and assumed areal extent of the

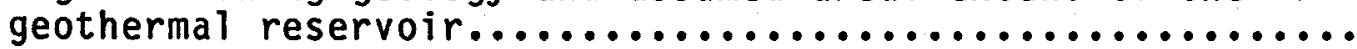

34 Pagosa Springs, geology and assumed areal extent of the

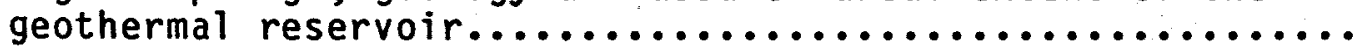

35 Rainbow Hot Springs, geology and assumed areal extent of the geothermal reservoir............................. Map of Wagon Wheel Gap Hot Springs region showing geology and assumed areal extent of the geothermal reservoir.......

37 Map of Antelope and Birdsie Warm Springs region showing geology and assumed areal extent of the geothermal reservoir. Map showing assumed areal extent of the Waunita Hot Springs geothermal reservoir and surrounding geologic conditions....

39 Geology surrounding Cebolla Hot Springs and assumed areal extent of the geothermal reservoir.................... 102

40 Orvis Hot Spring, geology and assumed areal extent of the geothermal reservoir............................... 104

41 Map of Ouray area showing geology and asssumed areal extent of the geothermal reservoir......................... 106

42 Map of Lemon Hot Springs area showing geology and assumed areal extent of the geothermal reservoir................. 108

43 Map of Dunton and Geyser Hot Springs area showing geology and assumed areal extent of the geothermal reservoir....... 112

44 Rico area, geology and assumed areal extent of the geothermal reservoir............................. 114

45 Pinkerton, Mound, Tripp and Trimble Hot Springs area, geology and assumed areal extent of the geothermal reservoir......................................... 118 


\section{TABLES}

$\underline{\text { PAGE }}$

1 Alphabetical list of thermal springs and wells in Colorado......................................... 124

2 Resource assessment of hydrothermal resources in Colorado........................................... 126

3 Estimated reservoir temperatures $\left({ }^{\circ} \mathrm{C}\right) \ldots \ldots \ldots \ldots \ldots \ldots \ldots . \ldots 129$

4 Reported but unconfirmed hot springs or wells.......... 136

5 Well in San Luis Valley having measured temperatures

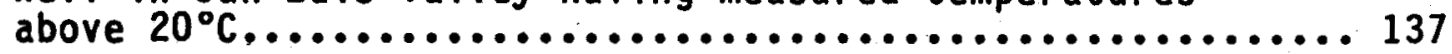

6 Newly located thermal wells in the Canon City area........ 138 


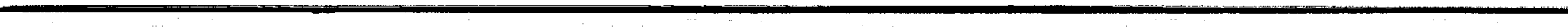

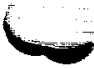

vili 


\section{ABSTRACT}

As part of its effort to more accurately describe the nations geothermal resource potential, the U.S. Department of Energy/Division of Geothermal Energy contracted with the Colorado Geological Survey to appraise the hydrothermal (hot water) geothermal resources of Colorado. Part of this effort required that the amount of energy that could possibly be contained in the various hydrothermal systems in Colorado be estimated.
This pubiication presents the findings of that assessment. To make these estimates the geothermometer reservoir temperatures estimated by Barrett and Pearl (1978) were used. In addition, the possible reservoir size and extent were estimated and used. This assessment shows that the total energy content of the thermal systems in Colorado could range from $4.872 \times 1015$ BTU's to $13.2386 \times 10^{15}$ BTU's.

\section{INTRODUCTION}

As part of its effort to more accurately describe the nations geothermal resource potential, the U.S. Dept. of Energy/Division of Geothermal Energy (DOE/DGE) has contracted with representives in each of the western states to appraise the low temperature $\left(1\right.$ ess than $200^{\circ} \mathrm{C}$ ) geothermal resources in their respective state. In July, 1977, under DOE/DGE contract No. EG-77-5-07-1678, the Colorado Geological Survey began a $21 / 2$ year assessment of the low temperature geothermal resource potential of Colorado and Feservoir confirmation program. This publication reports the findings of the resource assessment phase of the contract.

In most instances the thermal waters of Colorado are unused, although small amounts of thermal waters are used for recreation, space heating, domestic, and miscellaneous agricultural purposes. Although many energy companies have expressed interest in the geothermal resources of the state and have acquired leases to federal, state and private lands, no large scale development has occurred.

The geothermal resources of Colorado appear to be ideally suited for processes requiring low to moderate temperature hot water. In 1978 Barrett and Pearl calculated the estimated reservoir temperatures of all the thermal systems in Colorado. Their calculations showed that the reservoir temperatures range from a low of $20^{\circ} \mathrm{C}$ to over $200^{\circ} \mathrm{C}$, with most of the temperatures being in the range of $50^{\circ} \mathrm{C}$ to $150^{\circ} \mathrm{C}$.

Colorado's geothermal resource potential is expressed in the numerous thermal springs and wells found throughout the western one-half of the state (Fig. 1). These springs and wells, numbering over 120, have been described by numerous authors. The first and most comprehensive inventory of the thermal springs and wells was published in 1920 by R. D. George and others. Since then summaries have been published by Barrett and Pearl (1978), Lewis (1966), Mallory and Barnett (1973), Pearl (1972), and Waring (1965).

Various authors have attempted to define those thermal areas of Colorado that might have potential

$r$ containing geothermal resources or the amount heat contained in them. In 1971 Goodwin and others, published a comprehensive analys is of 1 ands in the western United States that might contain geothermal resources. Their report showed that there are approximately 32 areas in Colorado that have the potential for containing geothermal resources. Brook and others in 1979, Renner and others in 1975 and Sammel, 1979 made a tenative appraisal of Colorado's geothermal resource potential, and calculated the amount of heat contained in those reservoir having estimated reservoir temperatures above certain temperatures.

In 1978 Barrett and Pearl published a comprehensive appraisal of Colorado's geothermal resources. In addition to locating 127 thermal springs and wells having a temperature above $20^{\circ} \mathrm{C}$ $\left(68^{\circ} \mathrm{F}\right)$ and making such field measurements as discharge, $\mathrm{pH}$, conductivity, and temperature they made a general appraisal of the hydrogeological conditions, recharge areas, and reservoir temperatures surrounding each thermal area. A geothermometer determination of the estimated reservoir temperature was made for all the thermal areas in the State. The four major geothermometer models they used were: 1) Silica, 2) Mixing Models I and II, 3) Sodium-Potassium, and 4) Sodium-Potassium-Calcium. In order to clarify the use of these models, a detailed explanation of each was presented.

Barrett and Pearl (1978) determined the location of the spring or well to the nearest degree, minute and second of latitude and longitude by the use of either 7.5-minute or 15-minute U.S. Geological Survey topographic quadrangle maps. The land grid location was also determined if the township, range, and section had been determined and printed on the topographic map. To avoid confusion by the use of varying ambient air temperatures throughout western Colorado, Barrett and Pearl (1978) assumed an ambient air temperature of $60^{\circ} \mathrm{F}\left(15.6^{\circ} \mathrm{C}\right)$. A base thermal temperature of $20^{\circ} \mathrm{C}\left(68^{\circ} \mathrm{F}\right)$ was then used. Evaluation of their data shows that there are 56 distinct thermal areas within the State, consisting of one or more groups of springs or wells (Barrett and Pearl, 1978). More recent work has shown that there are at least 58 thermat areas in Colorado. 
This current investigation by the Colorado Geological Survey attempts to refine those earlier estimates of Colorado's geothermal resources. In making this effort the author, with the aid of $\mathrm{Mr}$. Jay Dick, drew heavily and freely upon conclusions and findings published in papers by Barrett and Pearl (1976 and 1978). Most of the text in this publication is an abridged version of Barrett's and Pearl's 1978 report. For a complete description of their findings and conclusions the reader is referred to their paper. The author, using geological maps published by Barrett and Pearl (1978) plus his knowledge of the geological-and hydrogeological conditions of each thermal area, attempted to draw boundaries around what he felt was the limits of the reservoir. It should be remembered that with the exception of very fe: sites no geological, hydrogeological, geophysical surveys have been done in or adjacent to these thermal areas. Therefore all est imates of the reservoir sizes, depths, and heat contained in them should be viewed with caution. unt il supported. or refuted with exploration data.

Figure 1 shows the location of the thermal springs or wells in Colorado. The numbers in the figure correspond to the order in which the springs and wells are discussed in the text.

Table 1 is an alphabetical listing of all the thermal springs and wells in Colorado.

\section{RESOURCE ASSESSMENT PROCEDURE}

With the exception of a few of the thermal systems in Colorado, most of the thermal systems' depth, size and hydrogeological conditions are unknown. Therefore, before calculating the energy contained in each system; it was necessary to estimate those parameters. It cannot be stressed strongly enough that these parameters are estimates and that until definitive test drilling or geophysical surveys which will more accurately portray the thermal systems are done, all conclusions should be viewed with these limitations in mind. The estimates are presented in Table 2.

In making this assessment the following procedure was followed.

1. The areal extent of the reservoir, based on an assessment of the regional geological conditions, was estimated. In several instances two estimates of the reservoir size were made, a conservative estimate and an optimistic estimate.

2. Reservoir thickness. Of all the estimates made this was the most difficult. The reservoir was first estimated to be a fractured or a stratigraphic reservoir. If the reservoir was estimated to to be a stratigraphic reservoir, it was then determined which formation would most logically be the reservoir. In some instances this was not possible, and a generalized approach was taken. After the reservoir type had been estimated the total thickness of the reservoir was estimated. If the reservoir was believed to be a fractured reservoir, an arbitrary thickness of $1,000 \mathrm{ft}$ was assigned. If the reservoir type was unknown, a thickness of $500 \mathrm{ft}$ was asssigned. Thickiness of the stratigraphic reservoir was based on the thickness of the assumed water bearing unit.

3. The usable reservoir temperature $(\Delta t)$ is the difference between the temperatures as presented by Barrett and Pearl (1978) and $20^{\circ} \mathrm{C}$.

4. The heat content in British Thermal Units (BTU's) in each system was calculated using the following formula. BTU's $=\frac{\left(\mathrm{mi}^{2} \times 2.59 \times 10^{10}\right)(\text { Thick } / \mathrm{ft} \times 30.48)(.6)(\Delta t)}{252}$

The heat content of a system is reported in Quad's (Q's) $(1,000,000,000,000,000$ or 1015 . Btu's). For example the heat content of Juniper Hot Springs is estimated to be $.10616 Q^{\prime} s$, this is $.10611 \times 1015$ BTU's.

5. For those systems where two different reservoir sizes had been estimated, two estimates of the total BTU's in the ground were calculated.

6. In many instances the amount of heat contained in each system will differ from those estimates made earlier by Brook and others others (1979) and Brook and others (1975) and Sammel (1979). This is due to the author attempting to define each system individually rather than assume set reservoir parameters. For a complete description of how Brook and others (1979), Renner and others (1975), and Sammel (1979) made their determinations the reader is referred to their papers.

\section{GEOTHERMOMETER MODELS-THEORY AND EXAMPLES}

Research by Fournier (1973, and 1977), Fournier and Rowe (1966), Fournier and Truesdeli $(1972,1973$, and 1974), Fournier and others (1974), Truesdel1 and Fournier (1975), and White (1972) on the relationship between the concentration of ions in thermal waters and reservoir temperatures has led to the development of a number of geothermometer models that can be used to estimate the subsurface reservoir temperature. The most frequently used geothermometers are related to th silica, sodium, potassium, and calcium content thermal waters. 


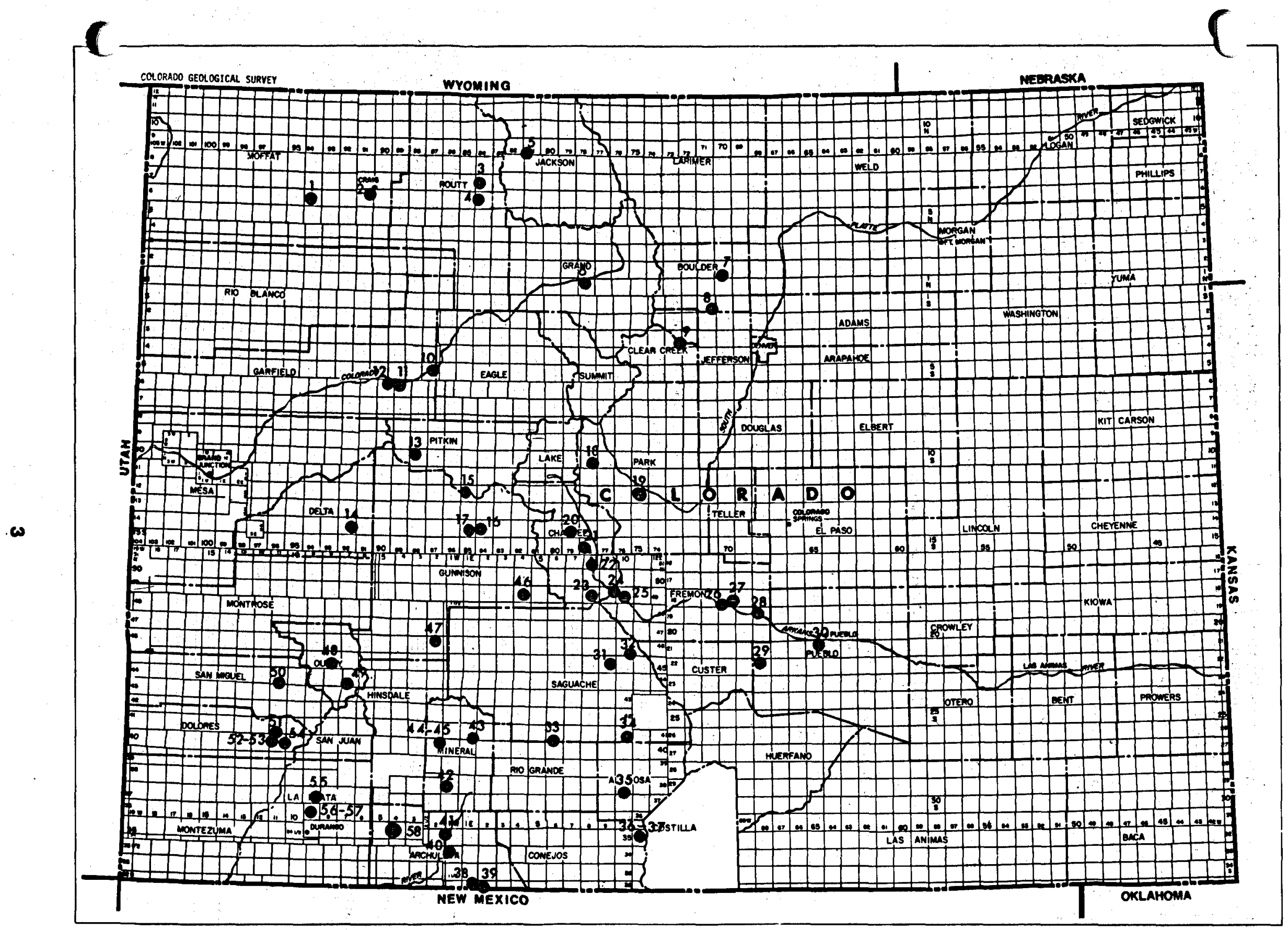

Figure 1.--Location of thermal springs and wells in Colorado. Numbers identify thermal areas. Thermal areas are discussed in numerical sequence beginning on page 9 . 
The following assumptions are inherent in all geothermometer model s (Fournier and others, 1974). Violation of any of these assumptions may cause erroneous subsurface temperature estimates:

1) Temperature-dependent reactions occur at depth.

2) A11 constituents involved in a temperature dependent reaction are sufficiently abundant (i.e., supply is not a limiting factor).

3) Water-rock equilibration occurs at the reservoir temperature.

4) Little or no re-equilibration or change in composition occurs at lower temperatures as the water flows from the reservoir to the surface.

5) The hot water coming from deep in the system does not mix with cooler shallow ground water.

Following is a brief discussion of each geothermometer model. For a complete description of the theory, application, and solution of these models the reader is referred to Barrett's and Pearl's paper or papers by Fournier (1973 and 1974), Fournier and Rowe (1966), Fournier and Truesdell (1972, 1973, and 1974), Fournter and others (1974), Truesde11 and Fournier (1975), or White (1972).

\section{SILICA GEOTHERMOMETER MODELS}

The silica geothermometer is derived from the experimentally determined relationship between silica-solubility, temperature and pressure (Fournier, 1973). Dissolved silica found in thermal waters may be supplied by temperature-dependent reactions between the thermal water and either quartz, chalcedony, amorphous silica or cristobalite.

Application of the various silica geothermometer models is restricted by four assumptions :

1) No mixing occurs between ascending thermal waters and shallow ground water.

2) Silica does not precipitate from the solution.

3) Steam does not separate from the thermal water during ascent to the surface.

4) The chemical activity of the thermal water is not greatly diminished.

\section{QUARTZ-SILICA GEOTHERMOMETER}

The quartz-silica geothermometer is based on temperature-dependent equilibration between quart $z$ and the thermal fluid. Quartz is the predominant source of silica above $150^{\circ} \mathrm{C}$. If the deep-seated geothermal waters were originally at temperatures above $225^{\circ} \mathrm{C}$, silica precipitation would likely occur during ascent to the surface. However, the rate of silica precipitation decreases rapidly below $180^{\circ} \mathrm{C}$. The quartz silica geothermometer is most reliable as a subsurface temperature indicator in moderately discharging (greater than $50 \mathrm{gpm}$ ) or high temperature (greater than $50^{\circ} \mathrm{C}$ ) hot springs with a silica content greater than $100 \mathrm{mg} / 1$ and subsurface temperatures between $150^{\circ} \mathrm{C}$ to $225^{\circ} \mathrm{C}$ (Fournier and Truesdel1, 1972 and 1974).

\section{AMORPHOUS SILICA, CHALCEDONY, AND CRISTOBALITE SILICA GEOTHERMOMETERS}

At water temperatures below $150^{\circ} \mathrm{C}$, amorphous silica, chalcedony, or cristobalite rather than quartz may control the dissolved silica content of the thermal water (Fourner, 1973). Approximate solubility of the various forms of silica may be calculated by formulas presented by Fournier (1973). Temperatures may be calculated by formulas developed by Reed (1975).

The amorphous silica, chalcedony and cristobalite silica geothermometers should be used as a check on the quartz geothermometer. When the solubility of amorphous silica, chalcedony or cristobalite at the spring's surface temperature approaches the silica content of the spring, the quartz silica geothermometer does not apply. In such cases, other silica geothermometers should be used to calculate the subsurface temperature.

\section{MIXING MODELS}

Assumption No. 1 of the silica geothermometer model states that the ascending thermal waters do not mix with the shallow ground waters. However, in many, if not most, geothermal systems mixing does occur between the thermal waters and ground water. To deal with this problem Fournier and Truesdeli (1974) developed two models, Mixing Model I and Mixing Model II, to estimate the subsurface temperature and compute the fraction of cold ground water in the hot spring.

These models are based upon the relationship between the enthalpy (heat content) and the silica content of the ascending thermal water, the cold ground water, and the resultant mixed thermal spring water. Depending upon the relative amount and the initial enthalpies of the hot and col water, the mixed surface spring temperatures may 
range from cool to boiling (Fournier and Truesdell, 774).

The use of mixing models involves four additional assumptions to those discussed for the silica geothermometers.

1) Initial silica content is controlled by temperature-dependent reactions between the deep thermal water and quartz.

2) Additional silica is not dissolved or deposited after mixing.

3) Enthalpy is not lost by conductive cooling or steam loss before mixing.

4) The temperature and silica content of cold springs are similar to the temperature and siliica content of the ground water that mixes with the ascending hot water.

Analysis of subsurface temperatures using the Mixing Model requires knowledge of the surface temperatures and silica contents of the thermal and nonthermal waters in the area. As many cold springs or wells as possible should be sampled in the vicinity of the hot spring to insure an adequate representation of the regional ground-water conditions. If no cold springs or wells exist in the area, the following assumptions can be made: The cold water can be assumed to have a silica content of $25 \mathrm{mg} / 1$, and the temperature of the cold water may be assumed to equal the mean annual air temperature of the region.

\section{MIXING MODE NO.I}

Subsurface reservoir temperatures may be estimated by Mixing. Model I either by graphical techniques or by use of a computer program (Truesdell and others, 1973).

Calculation of subsurface temperatures using the Mixing Model requires the knowledge of the surface temperatures and silica contents of the thermal and nonthermal waters in the area. If no cold springs or wells exist in the area, the above assumptions have to be made.

\section{MIXING MODE NO. \|}

For some thermal systems, it is not possible to calculate the temperature, or the calculated temperatures are unrealistically high. This may be caused by either loss of steam from the ascending hot water prior to mixing or by the solution of amoprhous silica. For those systems, fournier and Truesdell (1974) developed a geothermal model called the Mixing Model. II. This model is applicable to those thermal systems where steam vents or fumaroles are present at the surface and the solution of amorphous silica is not significant (Fournier and Truesde11,1974). If amorphous silica is supplying silica ions to the thermal water, then Mixing Model I provides excessive subsurface temperature estimates. If amorphous silica is not supplying any silica to the system, then steam separation separation is likely.

Mixing Model II should only be used when mixing model assumption 3 is violated, i.e, when steam is lost from the ascending hot water before mixing. In this case the enthalpy and silica content of the hot water at depth are greater than the enthalpy and silica content of the hot water after steam separation. The amount of steam fractionation and the resultant silica enrichment are estimated by assuming steam loss at atmospheric pressure for the hot springs elevation (Fournier and Truesdell, 1974).

\section{OTHER MIXING MODELS}

At temperatures below $150^{\circ} \mathrm{C}$ amorphous silica, chalcedony, or cristobalite rather than quartz may control the dissolved silica content of the hot spring (Fournier, 1973). Temperature-dependent equilibration between the thermal water and solid silica phases other than quartz will cause the mixing model estimates of subsurface temperature and cold water fraction to be too high (Assumption No. 1). If the silica concentration of the thermal water approaches the theoretical solubility of amorphous silica, chalcedony or cristobalite at the spring's surface temperature, then mixing models based on amorphous silica, chalcedony, or cristobalite should be used.

These models are identical to Mixing Model I in all respects except for the assumption that amorphous silica, chalcedony, or cristobalite rather than quartz is the source of silica in the thermal water.

\section{SUMMARY}

Mixing Models I and II yield maximum and minimum subsurface temperature estimates, respect ively (Fournier and Truesdel1, 1974). They are best suited for the analys is of moderately discharging (greater than $50 \mathrm{gpm}$ ) hot springs with silica concentrations above 75 to $100 \mathrm{mg} / 1$. These models should provide similar subsurface temperature estimates for multiple hot spring systems where each spring contains different proportions of cold water or for spring areas where mixing fluctuates seasonally. Even if the mixing model results should vary widely, the data obtained can be useful for evaluating the accuracy of the assumptions involved in geothermometer analysis.

\section{ENTHALPY_CHLORIDE GEOTHERMOMETER}

Mixing Mode1s I and II are useful for the ediction of subsurface temperature from mixed hot springs. However, neither geothermometer model commonly predicts temperatures in excess of $200^{\circ} \mathrm{C}$ even in thermal systems where higher temperatures have been substantiated by deep drilling (Truesdell 
and.Fournier, 1975 ).

To solve this problem, Truesdell and Fournier (1975) developed a mixing model in which chloride rather than silica ions are used in the calculation. This model, called enthalpy-chloride mixing model, was designed to calculate subsurface temperatures and hot water fractions for groups of mixed springs that issue at the boiling point. The derivation of this model is based upon the relationship between the enthalpies and chloride contents of the ascending hot water, the cold ground waters, and the resultant mixed warm spring waters.

The enthalpy-chloride geothermometer model is based on the following four assumptions (Truesdell and Fournier 1975):

1) An unmixed hot water sample is available.
2) Silica is not precipitated during ascent of the mixed water. Precipitation of silica after mixing will lower the enthalpy of the thermal solution, thus causing the estimated subsurface temperatures to be too $10 \mathrm{w}$.

3) No change in enthalpy occurs before or after mixing. Enthaply loss during ascent reduces the estimated subsurface temperature.

4) Quartz re-equilibration occurs after mixing. Hot water mixing with cold water usually creates a solution that is supersaturated in silica. If pre cipitation of silica does not occur, then the enthalpy of the solution will be too high. This resultis in an excessive subsurface temperature estimate.

\section{SODIUM-POTASSIUM-CALCIUM GEOTHERMOMETER MODEL}

The Na-K-Ca geothermometer model developed by Fournier and Truesdel1 (1973) is based on an empirical relationship between the molar concentrations of sodium, potassium and calcium ions and water temperature. This relationship is interpreted by Fournier and Truesdell (1973) as representing the temperature-dependent chemical equilibration between sodium, potassium, and calcium-bearing minerals and water.

Use of the $\mathrm{Na}-\mathrm{K}-\mathrm{Ca}$ geothermometer requires three assumptions:

1) No mixing occurs between the ascending thermal water and shallow ground water. If the calcium content of the undiluted thermal water is high (greather than 50 to $100 \mathrm{mg} / 1)$, then mixing with dilute ground water will cause the subsurface subsurface temperature estimate to be too low.
2) Sodium potassium and calcium concentrations in the thermal water are controlled by temperature dependent equilibration with albite, potassium feldspar and calcium-bearing minerals.

3) Little or no re-equilibration occurs during ascent.

Changes in the sodium-potassium-calcium ratios in thermal waters may be great or negligible depending upon the rate of ascent and the relative reactivity of the rocks and minerals along the flow path. Low calcium-content thermal waters generally yield low subsurface temperature reactions during ascent (increased aqueous calcium ion concentration). High calcium content waters, however, may yield excesstve geothermometer temperature estimates because of calcium carbonate deposition.

\section{SODIUM-POTASSIUM GEOTHERMOMETER MODEL}

The Na-K geothermometer model is based on a relationship between the molar concentrations of sodium and potassium and water temperature. This model is based on the same assumptions as the sodium-potassium-calcium geothermometer model.

\section{SUMMARY}

The $\mathrm{Na}-\mathrm{K}$ and $\mathrm{Na}-\mathrm{K}-\mathrm{Ca}$ geothermometer models should only be used for spring waters in which other evidence of high subsurface temperatures are present (i.e. springs with high surface temperatures and high silica content). Subsurface temperatures estimates greater then $100^{\circ} \mathrm{C}$ should be treated skeptically for moderately discharging springs (15 $\mathrm{gpm}$ ) unless the results are substantiated by other geothermometers. Both geothermometers are intended for the analysis of low magnesium (below $5 \mathrm{mg} / 1$ ) and of near-neutral and alkaline waters that do not deposit travertine. Travert ine and calcium carbonate-depositing springs yield excessive $\mathrm{Na}-\mathrm{K}$ and $\mathrm{Na}-\mathrm{K}-\mathrm{Ca}$ geothermometer subsurface temperature estimates. On the other hand, excessive solution of calcium carbonate w lower the $\mathrm{Na}-\mathrm{K}-\mathrm{Ca}$ geothermometer estimate (Fourn and Truesdell, 1973). 


\section{DESCRIPTION OF INDIVIDUAL THERMAL AREAS}

Following is a description of the individual thermal areas in Colorado. For this report, a thermal area is defined as an area consisting of one or more springs or groups of springs. For example, Orvis Hot Spring, consisting of only one spring, is considered a thermal area, while the Chalk Creek area on the south flank of Mount Princeton, which contains numerous hot springs and wells, is al so considered a thermal area.

Each thermal area is numbered on the index map (Fig. 1). For example, Area \#1, in the northwest corner of the map, is Juniper. Hot Springs. In the following discussion the thermal areas will be described in numerical, rather than alphabetical order so that all the thermal areas in the same region can be discussed together.

Each spring or group of springs is discussed in the following manner:

1. The location of the spring or springs is presented in several ways:

a) latitude and longitude.

b) township, range and section (Fig. 2).

c) county

d) the topographic quadrangle map in which the area is located.
2. Directions are given to the area from the nearest town or other prominent geographic feature. Any other pertinent facts about the area, where available, are given.

3. The hydrology and geological conditions of the area are discussed. Reported are such measured hydrological parameters as: temperature, $\mathrm{pH}$, concentration elemental ions if determined, the measured conductance values, and water type. For most thermal areas a geological map was prepared. In many instances, these maps were adopted from previously published geologic maps of the area by reconnaissance geologic mapping.

4. The subsurface temperature of each spring or spring area was determined utilizing the Silica, Mixing Model, Sodium-Potassium (Na-K), and Sodium-Potassium-Calcium (Na-K-Ca) geothermometer models. Before applying the silica and mixing model geothermometers it was determined from silica sol ubility and temperature rel ationships which form of silica was controlling the silica found in the waters.

5. Resource assessment. The estimated energy contained in each system was calculated using the method described earlier. 


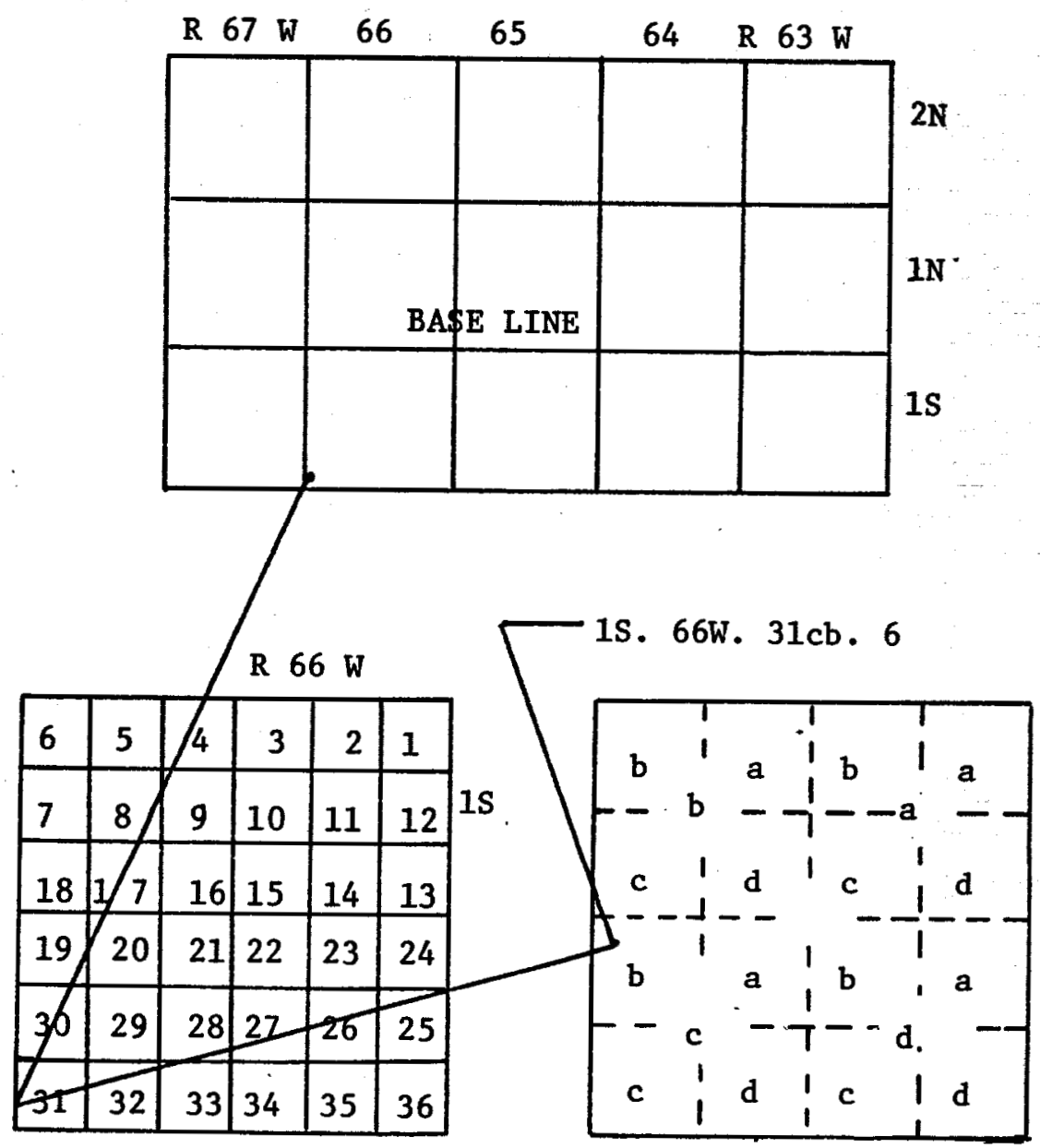

Figure 2: Spring Location numbering system used in Colorado

The well numbering system used in this report is based on the U.S. Bureau of Land Management system of land subdivision, and shows the location of the spring or well by township, range, section, and position within the section. In this report a 71 lands are referenced to the 6 th Principal Meridian or the New Mexico Principal Meridian. The first two segments of the number designate the township and range, the third number designates the section. The letters following the section number locate the feature within the section. The first letter denotes the quarter section, the second the quarter-quarter section. These letters are assigned within the section in a counter-clockwise direction beginning with "a" in the northeast quarter. Letters are assigned within each quarter section and within each quarter-quarter section in the same manner. In the example above the spring is located in the NW $1 / 4$, SW $1 / 4$, Sec. $31, T .1$ S., R. 66 W., 6th Principal Meridian. 


\section{\#I JUNIPER HOT' SPRINGS}

LOCATION: Latitude: $40^{\circ} 28^{\prime} 01^{\prime \prime N}$.; Longitude: $107^{\circ} 57^{1} 10^{\prime}$ W.; T. 6 N., R. 94 W., Sec. $16 \mathrm{~cd}, 6$ th P.M.; Moffat County; Juniper Hot Springs 7 1/2-minute topographic quadrangle map.

GENERAL: These springs are located on the south bank of the Yampa River in northwest Colorado, approximately 27 miles south and west of Craig, colorado. The waters from the springs are used in the swimming pool and for hot baths at the Juniper Hot Springs Lodge.

GEOLOGY AND HYDROLOGY: The springs emerge into the hot bath pools; therefore, it was not possible to obtain an accurate measurement of their temperature or discharge. Field measurements of these values throughout a year's time were: Temperature: $33^{\circ} \mathrm{C}$ to $38^{\circ} \mathrm{C}$; Discharge: 13 to $18 \mathrm{gpm}$; and total dissolved solids: $1,150 \mathrm{mg} / 1$. The waters are a sodium bicarbonate type.

Sears (1924) shows the Juniper Hot Springs occurring at a point of transition from the flanks of a southeasterly plunging syncline to the southeast flank of Juniper Mountain to the west. Sears has shown that the strike of the Cretaceous sedimentary formations change in the immediate vicinity of Juniper Springs from generally southeast to northeast. -Tweto (1975) states that a small section of undifferentiated Mesozoic sedimentary rocks is overlain by Cretaceous Mancos Shale at the site of the springs (Fig. 3). If this is the case, then a fault must 1 ie in the immediate vicinity of the springs. If present, this fault could be the conduit along which the waters move up from depth. - It is believed that the waters come from the Dakota Formation and migrate up faults associated with Juniper Mountain to the west.

GEOTHERMOMETER ANALYSES: Analysis shows that chalcedony may control the silica content of the hot springs (Barrett and Pearl, 1978). The chalcedony-silica geothermometer model gave an est imated subsurface temperature ranging from $47^{\circ} \mathrm{C}$ to $53^{\circ} \mathrm{C}$, based on varying silica content throughout the year's time. This estimate may be close to the actual temperature at depth because the theoretical chalcedony-induced silica solubility $(26 \mathrm{mg} / 1)$ at the surface temperature of the spring $\left(42^{\circ} \mathrm{C}\right)$ is near the silica content of the spring (29 to 33 $\mathrm{mg} / 1$ ).

Chalcedony mixing model analysis yields a subsurface temperature estimate of $73^{\circ} \mathrm{C}$ to $81^{\circ} \mathrm{C}$ with a cold water fraction of 55 to 61 percent of the spring flow (Table 3 ).

Calculations by Barrett and Pearl (1978), show that the $\mathrm{Na}-\mathrm{K}$ and $\mathrm{Na}-\mathrm{K}-\mathrm{C}$ geothermometers yield subsurface temperature estimates of $67^{\circ} \mathrm{C}$ to $75^{\circ} \mathrm{C}$ and $76^{\circ} \mathrm{C}$ to $80^{\circ} \mathrm{C}$, respectively (Table 3 ). The close agreement of these results with the other geothermometer estimates suggests they represent the actual temperature at depth.

Conclusion: Geothermometer models must be used with caution when applied to Juniper Hot Springs because samples of the thermal water were taken from large, quiescent pools. Such sampling situations may exaggerate the effects of the surface conditions on the thermal water, allowing evaporative concentration of the silica content and other re-equilibration reactions to occur.

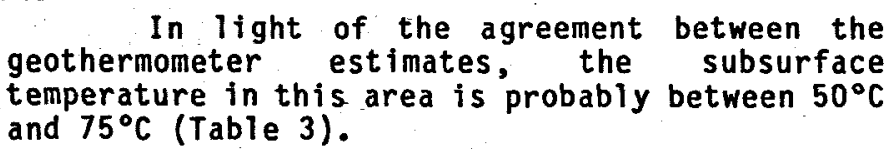

In light of the agreement between the geothermometer estimates, the subsurface temperature in this area is probably between $50^{\circ} \mathrm{C}$ and $75^{\circ} \mathrm{C}$ (Table 3 ).

RESOURCE ASSESSMENT: Barrett and Pearl (1978) conjectured that an unmapped fault might exist in the vicinity of this spring could be controlling its occurrence. In drawing the postulated boundaries of the system, the author attempted to draw the area big enough to include all of the supposed faulted area. It is therefore estimated that this area may encompass an area of $1.0 \mathrm{sq} \mathrm{mi}$, and contain .0163 Q's $\left(0.0163 \times 10^{15} \mathrm{~B} . T . U^{\prime} \mathrm{s}\right)$ of heat energy at an average temp. of $63^{\circ} \mathrm{C}$ (Table 2 ). 


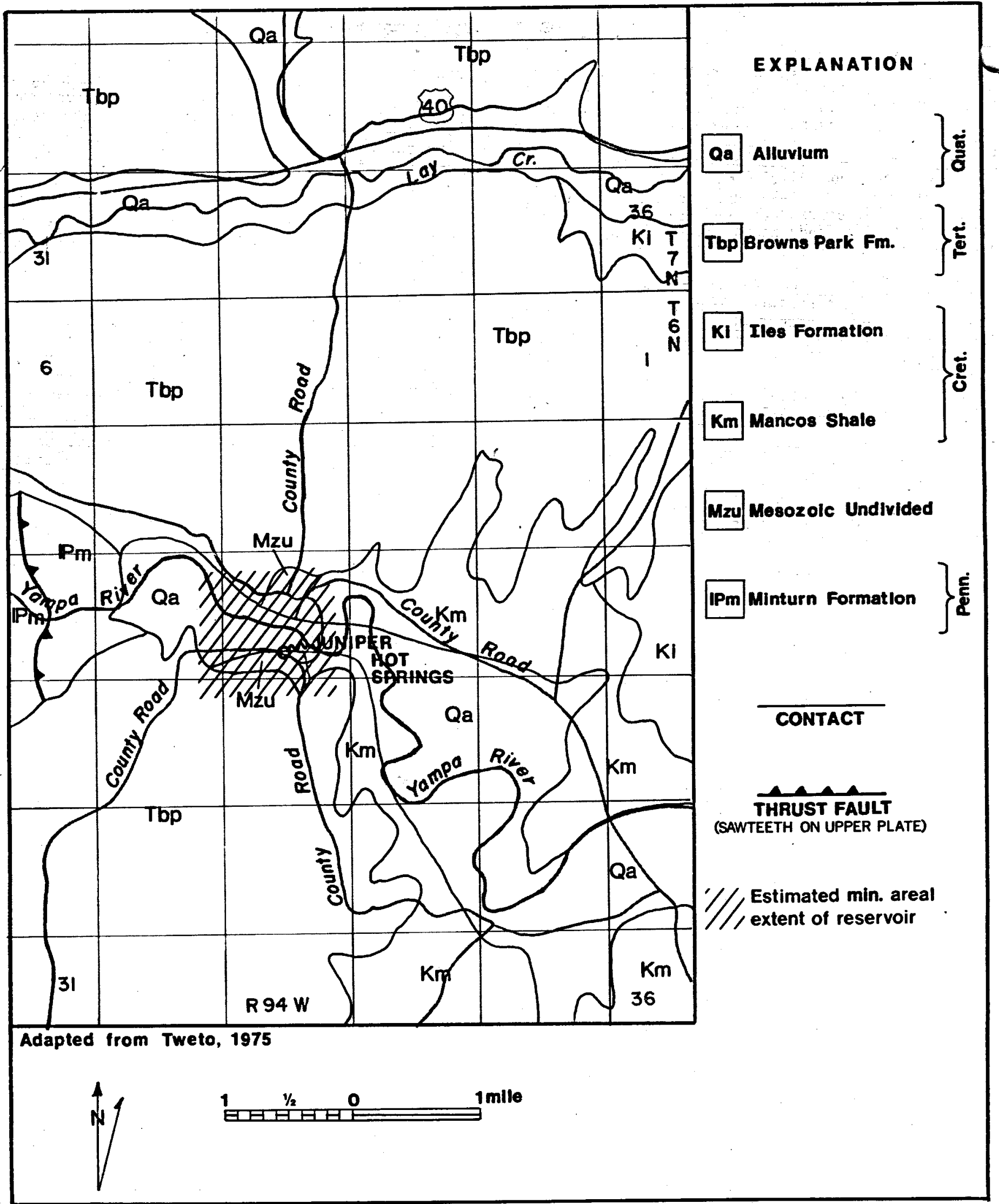

Figure 3.--Geologic map of Juniper Hot Springs area and extent of estimated geothermal reservoir. 


\section{\#2 CRAIG WARM WATER WELL}

LOCATION: Latitude: $40^{\circ} 30^{\prime} 06^{\mathrm{N}} \mathrm{N}$.; Longitude: $107^{\circ} 33^{1} 04^{~ W . ~}$.; T. 6 N., R. 91 W., Sec. 1 dcb, 6th P.M.; Moffat County; Craig 7 1/2-minute topographic quadrangle map.

GENERAL: The well, an oil test well, is reported to be $1,400 \mathrm{ft}$ deep. The well is located $0.75 \mathrm{mile}$ south of Craig near Col orado highways $13 / 789$. From these roads, one turns east on a dirt road, about $0.25 \mathrm{mile}$ north of the bridge over the Yampa River. The well is along the dirt road approximately 300 ft north of the farmhouse.

GEOLOGY AND HYDROLOGY: The surface temperature of this well is $39^{\circ} \mathrm{C}$ with a discharge of $24 \mathrm{gpm}$. The waters contain $896 \mathrm{mg} / 1$ of total dissolved solids (Barrett and Pearl, 1976). The bedrock of the area is the Lewis Shale of Late Cretaceous age. As shown on the geologic map (Fig. 4), al though no major structural features lie in the immediate vicinity of the well an east-west trending fault is located approximately 2 miles to the west.

Since the exact depth or construction of this well is not known, it is not possible to state with any degree of certainty from what formations the waters come from or their recharge area.

GEOTHERMOMETER ANALYSES:- Analysis shows that chalcedony or quartz may control the silica content of the artesian well (Barrett and Pearl, 1978). The quartz-silica geothermometer yields a subsurface temperature estimate of $58^{\circ} \mathrm{C}$ (Table 3 ). This appears to be the most reliable estimate. The chalcedony-silica geothermometer subsurface temperature estimate $\left(30^{\circ} \mathrm{C}\right)$, is below the surface temperature of the thermal water $\left(39^{\circ} \mathrm{C}\right)$.

Both quartz and chalcedony mixing models are applicable. The quartz mixing model yields a subsurface temperature estimate of $70^{\circ} \mathrm{C}$ with a cold water fraction of 50 percent. These estimates are probably excessive because the silica content and the flow rate of the artesian well are below the minimum conditions specified for the reliable application of this geothermometer.

The chalcedony mixing model yields a subsurface temperature estimate of $35^{\circ} \mathrm{C}$ with a cold water fraction of 20 percent of the total flow. Although the subsurface temperature estimate is below the surface temperature of the well $\left(39^{\circ} \mathrm{C}\right)$, it is within the expected margin of error.

The Na-K and Na-K-Ca geothermometers yield subsurface temperature estimates of $100^{\circ} \mathrm{C}$ and $104^{\circ} \mathrm{C}$, respectively (Table 3 ). Both of these estimates are too high because calcium carbonate is being deposited at the surface of the artesian well.

Conclusion: The subsurface temperature in this area is best represented by the chalcedony and quartz mixing models. Therefore, the temperature at depth is probably between $40^{\circ} \mathrm{C}$ and $60^{\circ} \mathrm{C}$ (Table $3)$.

RESOURCE ASSESSMENT: As seen on Fig. 4 , the well is located on the lower flank of an unnamed anticline. An outcrop of Tertiary age intrusive rocks is located approximately $31 / 2$ miles to the east. It is believed that the entire anticline should be considered as having potential for geothermal resources. The areal extent of the reservoir is estimated to either 1.3 or $12.0 \mathrm{sq} \mathrm{mi}$. Caiculations show that there may be between .0329 Q's (.0329 X $10^{15}$ B.T.U.'s) and .395 Q's (.395 $X$ 1015 B.T.U.' $s$ ) of energy contained in the system (Table 2). 


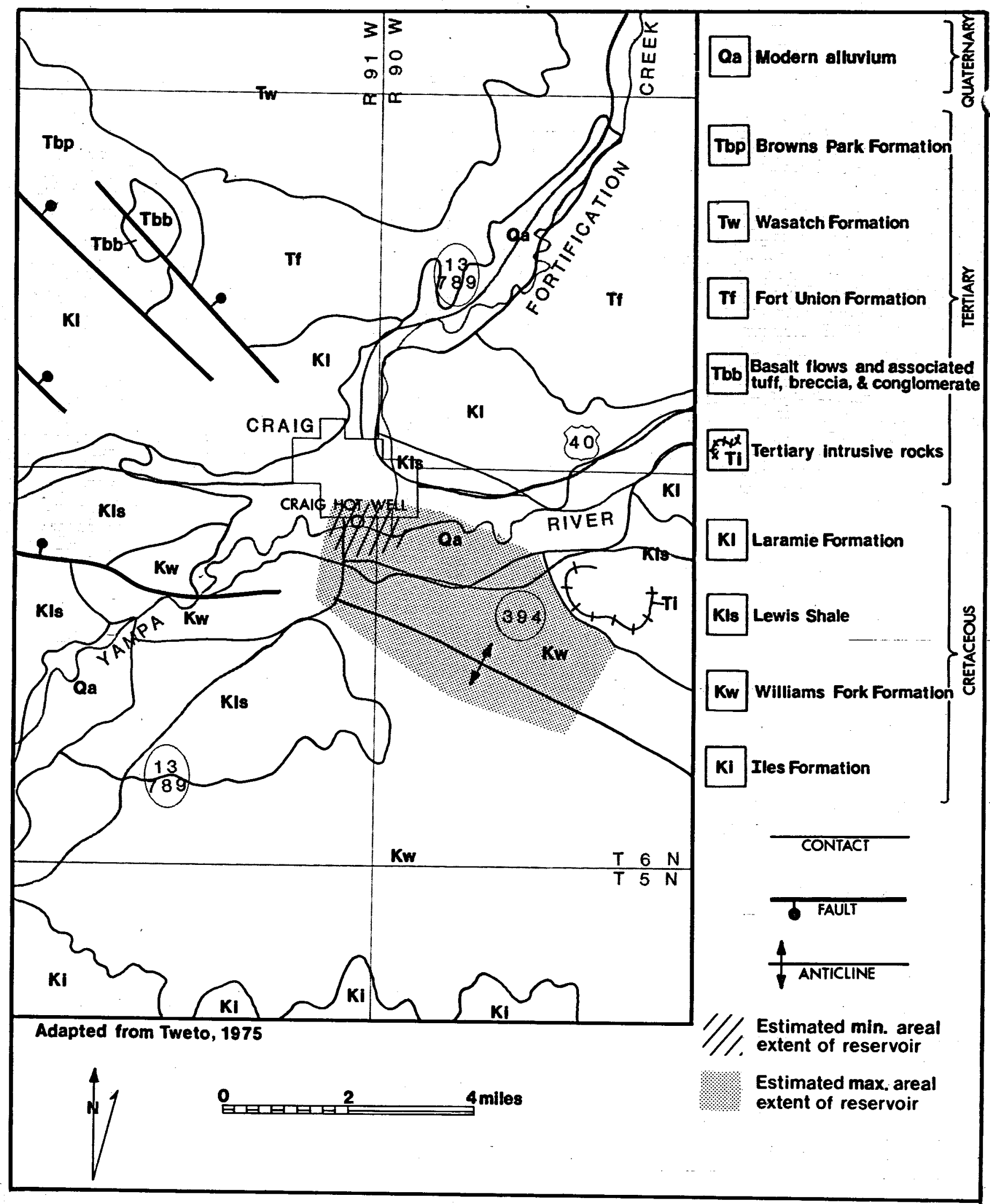

Figure 4.--Map showing geology surrounding Craig Warm Water Well and extent of estimated geothermal reservoir. 


\section{\#3 ROUTT HOT SPRINGS}

LOCATION: Latitude: $40^{\circ} 33^{\prime} 34^{\prime \prime N}$.; Longitude: $106^{\circ} 51^{\circ} 00$ "W.; T. 7 N., R. 84 W., Sec. $18 \mathrm{dc}, 6 \mathrm{th}$ P.M.; Routt County; Rocky Peak 7 1/2-minute topographic quadrangle map.

GENERAL: This group of 5 unused springs is located approximately 8 miles north of Steamboat Springs on Hot Spring Creek. Access is north on 7 th Street in Steamboat Springs past the hospital to Park Road, then north on this road to the springs.

GEOLOGY AND HYDROLOGY: The following springs were measured.

Spring A: Located approximately $100 \mathrm{ft}$ up the hillside on the south side of the creek; Temperature: $64^{\circ} \mathrm{C}$; Discharge: 25 to $50 \mathrm{gpm}$; Total Dissolved Solids: $518-552 \mathrm{mg} / 1$; Water Type: sodium chloride-bicarbonate.

Spring B:- Biggest spring on north bank of creek, approximately $5 \mathrm{ft}$ above the creek; Temperature: $62^{\circ} \mathrm{C}$; Discharge: $30 \mathrm{gpm}$; Total Dissolved Solids: $539 \mathrm{mg} / 1$; Water Type: sodium chloride-bicarbonate.

Spring C: Not sampled; Located $50 \mathrm{ft}$ east of Spring $A_{\text {; }}$ Temperature: $54^{\circ} \mathrm{C}$; Discharge: Est. $2 \mathrm{gpm}$; Conductance: 830 micromhos.

Spring D: Not sampled; Located approximately $40 \mathrm{ft}$ southeast of Spring $C$; Temperature: $51^{\circ} \mathrm{C}$; Discharge: Est. $2 \mathrm{gpm}$; Conductance: 830 micromhos.

No detailed geologic reports or maps have been prepared or published on this area. As shown by Tweto (1975), the springs issue from northwest-trending fracture zones within faulted Precambrian metamorphic rocks (Fig. 5).

Recharge of these springs may occur along the western edge of the Park Range to the east with deep circulation of the waters along fault zones in an area of above-normal heat flow.
GEOTHERMOMETER ANALYSIS: Calculations by Barrett and Pearl determined the following estimated subsurface temperatures: Quartz-silica geothermometer model yielded an estimated temperature of $125^{\circ} \mathrm{C}$ to $136^{\circ} \mathrm{C}$ (Table 3); Quartz mixing model yielded an estimated subsurface temperature of $192^{\circ} \mathrm{C} 231^{\circ} \mathrm{C}$ with a cold water fraction of 71 to 78 percent; the $\mathrm{Na}-\mathrm{K}$ and $\mathrm{Na}-\mathrm{K}-\mathrm{Ca}$ geothermometers yielded subsurface temperature estimates of $165^{\circ} \mathrm{C}$ to $170^{\circ} \mathrm{C}$ and $154^{\circ} \mathrm{C}$ to $159^{\circ} \mathrm{C}$, respectively (Table 3 ). The high surface temperature $\left(64^{\circ} \mathrm{C}\right)$, rapid flow (100 gpm) and close agreement with the mixing model results suggest that these are reasonable estimates.

Conclusion: The fluctuation of the various geothermometer estimates is within the range of values that could result from normal analytical error. The close agreement between the mixing model and the $\mathrm{Na}-\mathrm{K}-\mathrm{Ca}$ model estimates suggests that these geothermometers adequately reflect the temperature at depth. Therefore, these results and the precision of the geothermometers suggest temperatures at depth between $125^{\circ} \mathrm{C}$ and $175^{\circ} \mathrm{C}$ (Table 3).

RESOURCE ASSESSMENT: Due to the uncertainty of the reservoir size and extent, two estimates of reservoir extent were made. One estimate was based on the reservoir being restricted to the northwest trending fault zone (Fig. 5). This reservoir is estimated to have an areal extent of of $.5 \mathrm{sq} \mathrm{mi}$ and contained .1110 Q's of energy (Table 3 ).

During the summer of 1978, in an attempt to define this system, personnel from the U.S. Geological Survey ran several electrical geophysical surveys across the area. Preliminary analysis of the data shows that the thermal system is fault-controlled and restricted to an area of approximately $.50-.75 \mathrm{sq} \mathrm{mi}$ around the spring (Karen Christopherson, personal communication, 1978). This area could contain $.1663 \mathrm{Q}^{\prime}$ 's of heat energy at an average maximum temperature of $138^{\circ} \mathrm{C}$. (Table 2). 


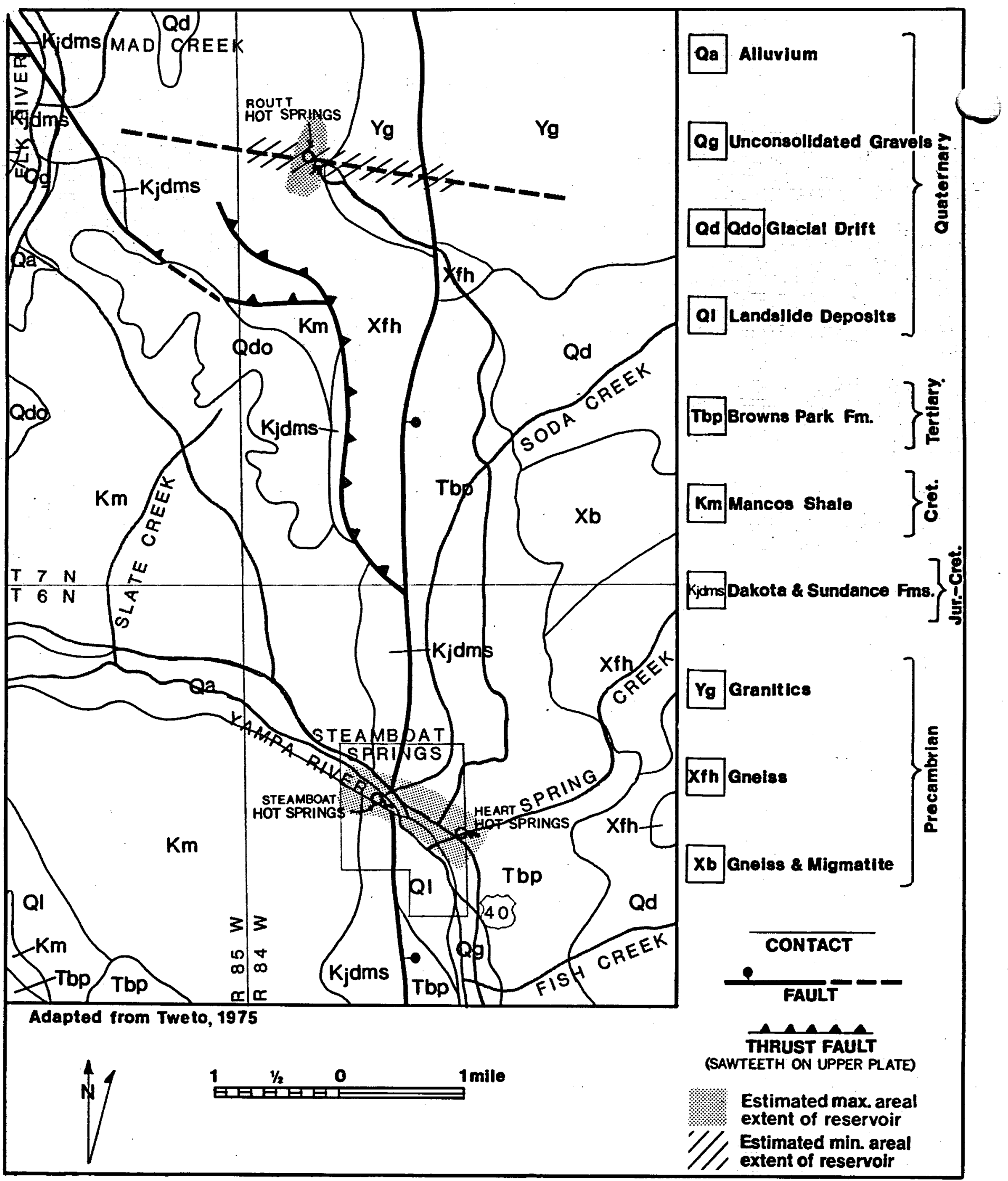

Figure 5.--Geology of Routt and Steamboat Springs and extent of estimated geothermal reservoir. 


\section{\#4 STEAMBOAT SPRINGS}

\section{LOCATION:}

(Heart Spring): Latitude: $40^{\circ} 28^{\prime} 58^{\prime \prime N . ; ~ L o n g i t u d e: ~}$ $106^{\circ} 49^{1} 37^{\prime \prime W}$.; T. 6 .N., R. 84 W.. Sec. 17 abd, 6th P.M.; Routt County; Steamboat Springs 7 1/2-minute topographic quadrangle map.

GENERAL: With the exception of the Heart Spring, which is located at the southeast end of the town, all the springs are unused at the present time. Waters from the Heart Spring are used in the large community swimming pool. The spring is located just to the northwest of the pool.

At the northwest end of town are several springs spread over a large area. Most of these springs are cold, but the original Steamboat Spring is warm. This spring is located on the west bank of the Yampa River along the railroad tracks, just to the west of the little City Park.

The other thermal spring, Sulphur Cave Spring, is located $1,100 \mathrm{ft}$ northwest of the rodeo grounds and approximately $80 \mathrm{ft}$ above the level of the river.

GEOLOGY AND HYDROLOGY: The Heart Spring has a temperature of $39^{\circ} \mathrm{C}$ with a discharge of $140 \mathrm{gpm}$. The total dissolved mineral matter in the waters is $903 \mathrm{mg} / 1$, and the waters are a sodium-chloride type with a strong concentration of sulfate.

Steamboat Spring has a temperature of $26^{\circ} \mathrm{C}$ with a discharge of $20 \mathrm{gpm}$. The waters are a sodium-bicarbonate type and contained $6,170 \mathrm{mg} / 1$ of dissolved mineral matter.

The waters of the Sulphur Cave Spring had a temperature of $20^{\circ} \mathrm{C}$ with a discharge of $10 \mathrm{gpm}$. The waters are a sodium chloride type and contain $4,530 \mathrm{mg} / 1$ of dissolved mineral matter.

As shown on Figure 5, these springs are situated on or just off of a major north-south trending fault paralleling the western front of the Park Range. This fault has brought sandstones of the Cretaceous Dakota Formation into contact with the Tertiary Brown's Park Formation. The Dakota Formation, primarily a sandstone unit, contains large amounts of sulfur-rich black shales. The Brown's Park Formation is a consolidated to semiconsolidated, coarse-grained sandstone that contains some shale and clay beds.

While no values of heat flow have been determined for this part of colorado, it is believed to be above normal. The occurrence of these thermal waters may be due to deep circulation of ground waters along some of the many faults found in the region.
GEOTHERMOMETER ANALYSES: Barrett and Pearl (1978) stated that the low surface temperature and flow of Steamboat and Sulphur Cave spring renders geothermometer analys is unrel iable; therefore, they only calculated the estimated reservoir temperatures for Heart Hot Spring.

The quartz-silica geothermometer model yields a maximum subsurface temperature est imate of $101^{\circ} \mathrm{C}$ (Table 3) (Barrett and Pearl, 1978). Quartz-silica mixing model analysis yields a subsurface temperature estimate of $179^{\circ} \mathrm{C}$ with a cold-water fraction of 81 percent of the spring flow. The low. silica content of this spring casts doubts upon the reliability of these estimates.

The $\mathrm{Na}-\mathrm{K}$ and $\mathrm{Na}-\mathrm{K}-\mathrm{Ca}$ geothermometer estimates of subsurface temperature are $148^{\circ} \mathrm{C}$ and $141^{\circ} \mathrm{C}$, respectively (Table 3 ). Although precipitation of calcium carbonate does not occur at the present time at this site, extensive travertine deposits exist in the western half of section $17, T, 6 \mathrm{~N}$., R.84 W. If these deposits represent current conditions at depth for Heart Hot Spring, then the $\mathrm{Na}-\mathrm{K}$ and $\mathrm{Na}-\mathrm{K}-\mathrm{Ca}$ geothermometer estimates are too high.

Conclusion: It is difficult to make a precise prediction of subsurface temperature for this area because of the wide range of geothermometer results and the unknown effects of the chemical additives on the water chemistry of the hot spring. However, the $\mathrm{Na}-\mathrm{K}$ and $\mathrm{Na}-\mathrm{K}-\mathrm{Ca}$ geothermometer est imates are substantiated by the analysis of the Routt Hot Spring group 5 miles northwest of this spring (see preceding section on Routt Hot Springs). The best est Imate of subsurface temperature for this area is between $125^{\circ} \mathrm{C}$ and $130^{\circ} \mathrm{C}$ (Table 3 ).

RESOURCE ASSESSMENT: A number of major faults have been been mapped in the vicinity of Steamboat Springs (Fig. 5). However, these springs appear to be located on the trace of an unmapped northwest trending fault (Karen Christopherson, personal communication, 1978). During the summer of 1978 , Ms. Christopherson, as part of the field work for her M.S. thes is requirements at the University of Colorado, ran several electrical geophysical surveys in the Routt-steamboat. Springs area. Because of cultural interference, she was not able to get as a complete definition of the reservoir at Steamboat Springs as at Routt Hot Springs. Analysis of her data shows that there is an unmapped fault trending northwest through the springs. Therefore, until proven otherwise, it will be assumed that the reservoir is fault controlled and extends only along the northwest fault. It is estimated that this reservoir has an areal extent of .52 $\mathrm{sq} \mathrm{mi}$ and contains .0487 $\mathrm{Q}^{\prime} \mathrm{s}$ of heat energy at an average maximum temperature of $70^{\circ} \mathrm{C}$ (Table 2). 


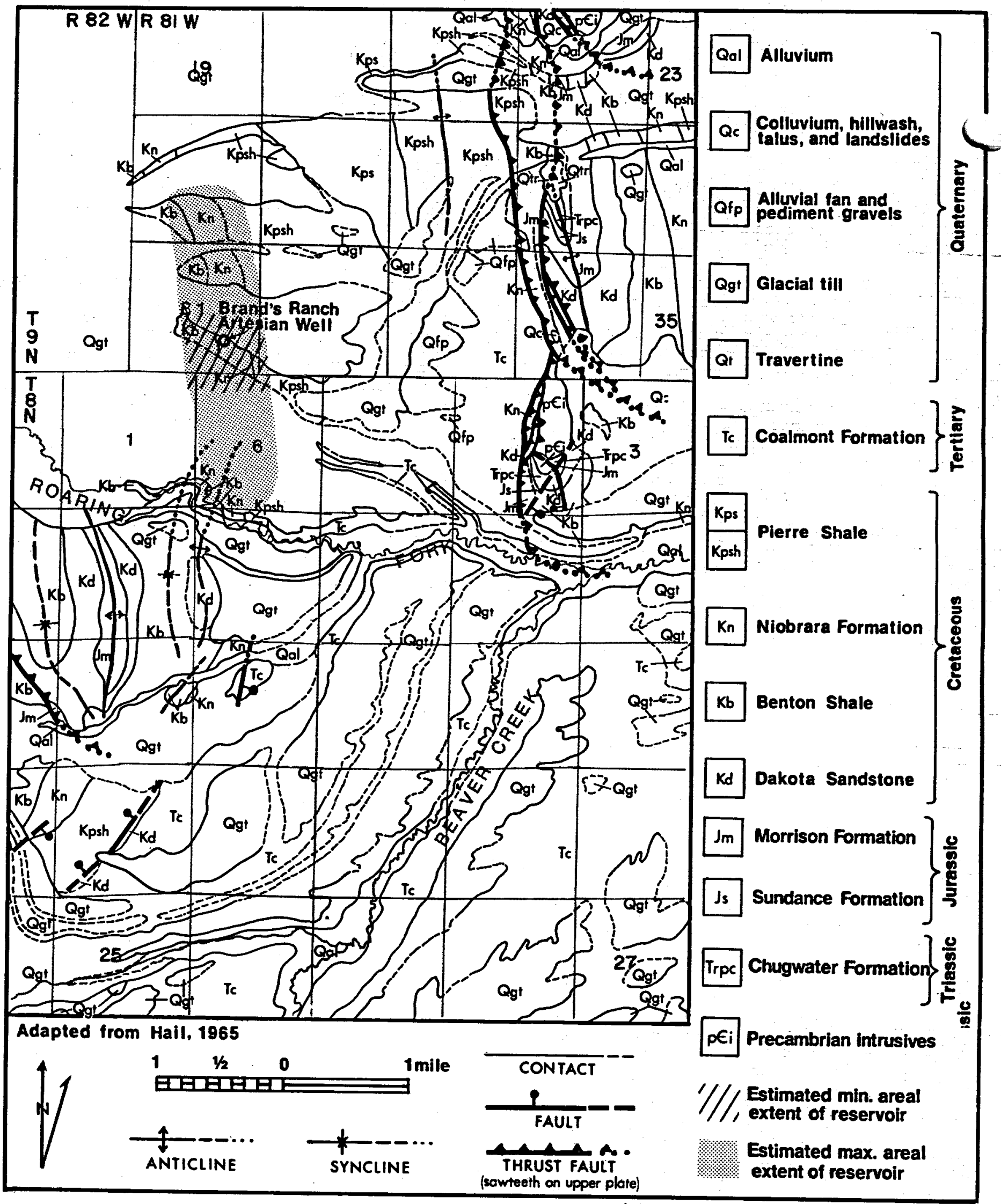

Figure 6.--Geology map of Brands Ranch Artesian Well and extent of estimated geothermal reservoir. 


\section{\#5 BRAND'S RANCH ARTESIAN WELL}

LOCATION: Latitude: $40^{\circ} 42^{\prime} 17^{\prime \prime}$ N.; Longitude: $106^{\circ} 32^{\prime} 05^{\prime \prime}$ W.;.T. 9 N., R. 81 W., Sec. 31 ded, 6 th. P.M.: Jackson County; Pitchpine Mountain 7 1/2-minute topographic quadrangle map.

GENERAL: This unused well is located west of Walden, Colorado, and may be reached by going 7.1 miles west of Walden on a paved county road to the North Platte River, cross the river and go 2.6 miles to an intersection. Turn right at the intersection and proceed 0.6 mile to an intersection near South Delaney Lake. Turn left on the dirt road and go west 3.8 miles to Brand's Ranch, a group of abandoned buildings. Go 0.2 miles west of the ranch and cross twin irrigation ditches. Turn right immediately west of the ditches and go 0.7 mile north on the dirt road along the west side. of the ditches. Park at the locked gate and walk $0.3 \mathrm{mile}$ east of the gate to a small foot bridge. The well is about $300 \mathrm{ft}$ south of the foot bridge in a swampy area in a pasture.

GEOLOGY AND HYDROLOGY: This artesian well, an old $0 i 1$ test well $800 \mathrm{ft}$ deep, has an estimated discharge of $80 \mathrm{gpm}$ at a temperature of $42^{\circ} \mathrm{C}$. The conductance of the water is 405 micromohs with a $\mathrm{pH}$ of 6.0

This well is located on the west side of North Park, a large intermontane basin in northwest Colorado. The geology of the area has been discussed in detail by Hail (1965). As shown on the geologic map (Fig. 6), the well is located on the outcrop of the Niobrara Formation, and no major faults have been mapped in the immediate vicinity of the wel1. It is postulated that the waters come from the Dakota, Sundance, or Chugwater Formations.

Recharge to the well probably occurs along the east flank of the Park Range to the west.

GEOTHERMOMETER ANALYSES: Analys is by Barrett and Peart (1978) of silica solubility and temperature relationships suggest that the chalcedony silica geothermometer should be used. The chalcedonysilica geothermometer subsurface temperature estimate is $42^{\circ} \mathrm{C}$ (Table 3 ), which is the same as the surface temperature of the hot wel1.

Chalcedony mixing model yields a subsurface temperature estimate of $43^{\circ} \mathrm{C}$ with a cold-water fraction of 1 percent of the total flow.
The Na-K and $\mathrm{Na}-\mathrm{K}-\mathrm{Ca}$ geothermometers yield subsurface temperature estimates of $199^{\circ} \mathrm{C}$ and $171^{\circ} \mathrm{C}$, respect ively. Al though no calcium carbonate deposits were noticed near the artesian well, 1 arge travertine deposits $(800 \mathrm{ft} \times 2000 \mathrm{ft} \times 25 \mathrm{ft}$ thick) occur in section $27, T .9$ N., R. 81 W. approximately 2.5 miles northeast of the artesian well (Fig. 6). Hail (1965) states that the spring waters responsible for this deposit ascend along a large reverse fault from unknown depth and surface at the junction of the fault and an an anticlinal axis. Field data for one of these springs follows (Barrett, unpublished field data):

$\begin{array}{ll}\text { Temperature } & 18^{\circ} \mathrm{C} \\ \text { Conductance } & 3500 \text { micromhos } \\ \text { pH } & 7.0 \\ \text { Discharge } & 1 \text { ess than } 2 \mathrm{gpm}\end{array}$

If the spring and thermal artesian well waters are of similar origin, then the travertine deposits around the springs may indicate similar conditions occurring at depth within the artesian well. If calcium carbonate is deposited within the artesian well, then the $\mathrm{Na}-\mathrm{K}$ and $\mathrm{Na}-\mathrm{K}-\mathrm{Ca}$ geothermometer estimates are too high $\left(199^{\circ} \mathrm{C}\right.$ and $171^{\circ} \mathrm{C}$, respectively).

Conclusion: The rapid flow of the well, the excellent agreement between the silica and mixing models with the temperature and silica content of the thermal water imply that the subsurface temperature is near the surface temperature of the artesian we11. The temperature at depth in this area, therefore, is probably $42^{\circ} \mathrm{C}$ to $55^{\circ} \mathrm{C}$ (Table 3).

RESOURCE ASSESSMENT: Two estimates of the reservoir's extent were made. One estimate showed that the reservoir may contain $0.36 \mathrm{sq} \mathrm{mi}$ and be restricted to an area just around the well. The other estimate showed that the reservoir may extend to the projected faults south and approximately 1.3 miles north of the well. This system may encompass an area of $1.5 \mathrm{sq} \mathrm{mi}$. The amount of energy est imated to be contained within this system varied from $.0039 Q^{\prime}$ 's to $.0164 Q^{\prime}$ 's at a temperature of $49^{\circ} \mathrm{C}$ (Table 2 ). 


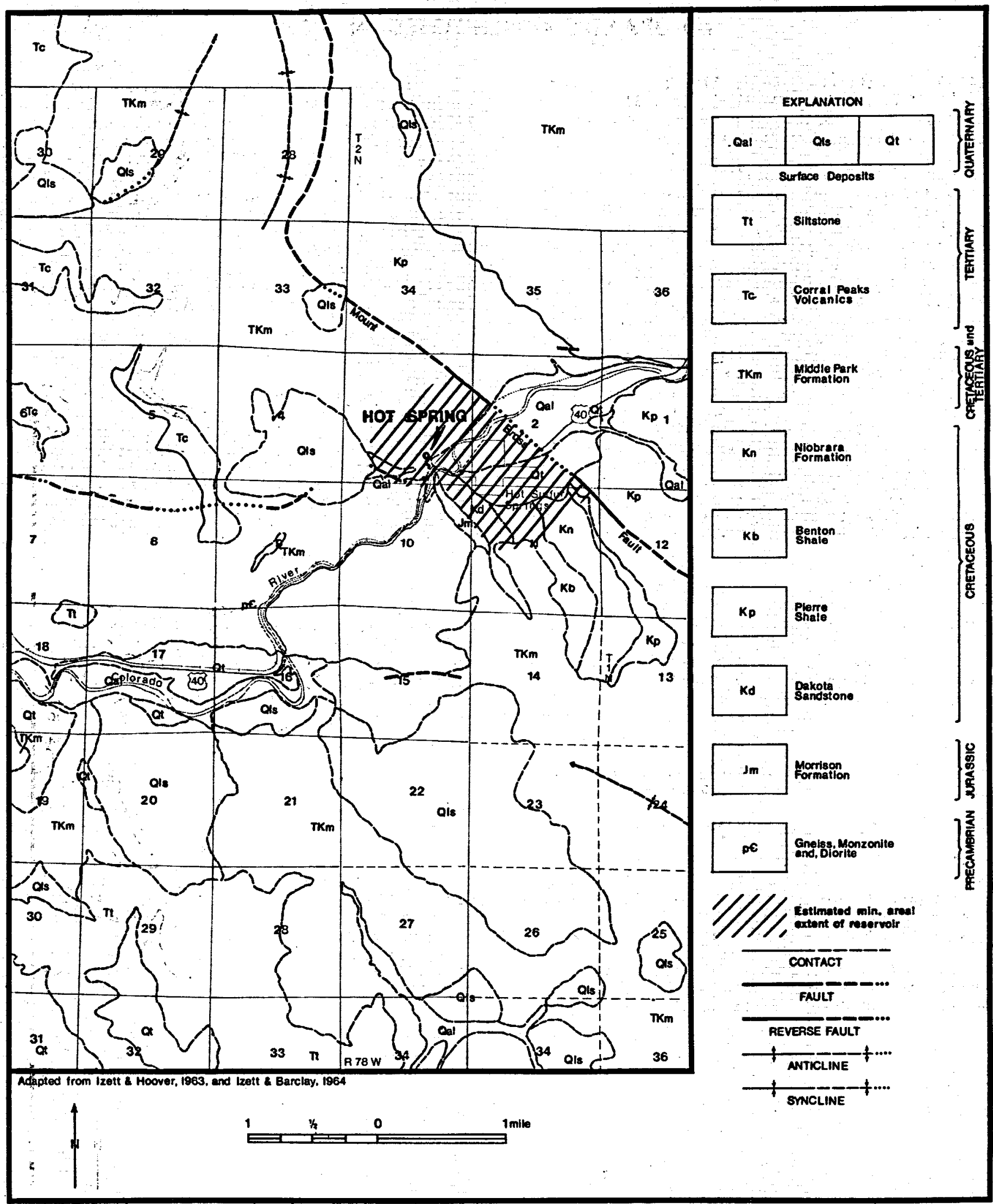

Figure 7.--Map showing geologic. conditions surrounding Hot Sulphur Springs and extent of estimated geothermal reservoir. 


\section{\#6 HOT SULPHUR SPRINGS}

LOCATION: Latitude: $40^{\circ} 04^{1} 33^{\mathrm{N} N}$; Longitude $106^{\circ} 06^{\circ} 43^{\prime \prime} W_{0} ;$ T. I N., R. 78 K., Sec. $3 \mathrm{dc}$, 6th P.M.; Grand County; Hot Sulphur Springs 15-minute topographic quadrangle map.

GENERAL: This group of springs is located immediately to the northwest of Hot Sul phur Springs on the north side of the Colorado River. Due to the modifications of the springs discharge points, it was not possible to accurately determine the number of springs; however, 5 to 10 springs appear to be present. Waters from the largest springs are piped to the various buildings on the property where the waters are used for swimming, steam baths, and laundry purposes.

GEOLOGY AND HYDROLOGY: The waters are a sodium bicarbonate type with a large concentration of sulfate. The total dissolved solids of the water is $1,200 \mathrm{mg} / 1$, and the temperature ranges from $40^{\circ} \mathrm{C}$ to $44^{\circ} \mathrm{C}$. While the discharge of the various springs ranges from 1 to $23^{*} \mathrm{gpm}$, the total discharge of all the springs is approximately 50 gpm. A large travertine deposit surrounds the spring. The waters come from the Dakota Sandstone, the underlying bedrock formation.

The geology of the surrounding area has been discussed in detafl by Izett (1968): The accompanying geologic map ( $F i g . ~ 7)$, taken from lzett and Hoover (1963) and Izett and Barclay (1964), shows that Precambrian igneous and metamorphic rocks are exposed less than one mile southwest of Hot Sulphur Springs in Byers Canyon. Uncomformably overlying these rocks and dipping to the northeast is a sequence, of sedimentary sandstones, siltstones, shales, and limestones, belonging in ascending order to the Morrrison, Dakota, Benton, Niobrara Formations and Pierre Shale. Overlying these formations is the Tertiary Middle Park Formation consisting of lava flows and associated rocks, siltstones and sandstones.

The Mount Brass Fau1t, a major northwest-trending thrust fault, occurs less than one half mile to the northeast of the springs. This fault may not control the occurrence of the springs since they are located on a small north trending normal fault. The thermal waters may be ascending along this fautt zone.

The occurrence of the thermal waters may be due to deep circulation of ground water along fault zones in an area having above normal geothermal gradients: Reiter (1975) has shown this area to have a heat flow of approximately 2.3 heat fiow units.

GEOTHERMOMETER ANALYSES: Most geothermometer techniques yield unreliable est imates when applied to Hot Sulphur Springs because many of the assumptions thicent in their use are violated (Barrett and Pearl, 1978)." The best geothermometer subsurface temperature estimate for this spring group is between $75^{\circ}$ and $150^{\circ} \mathrm{C}$ (Table 3 ).

RESOURCE ASSESSMENT: "For resource assessment purposes the reservoir is estimated to extend from the Mount Bross. Fault on the northwest to the small fault southwest of the springs. If this estimate of the reservolr extent (1.35 $\mathrm{sq} \mathrm{mi})$ is correct, it could contain .0698 Q's of energy at a temperature of $40^{\circ} \mathrm{C}$ (Table 2 ). 


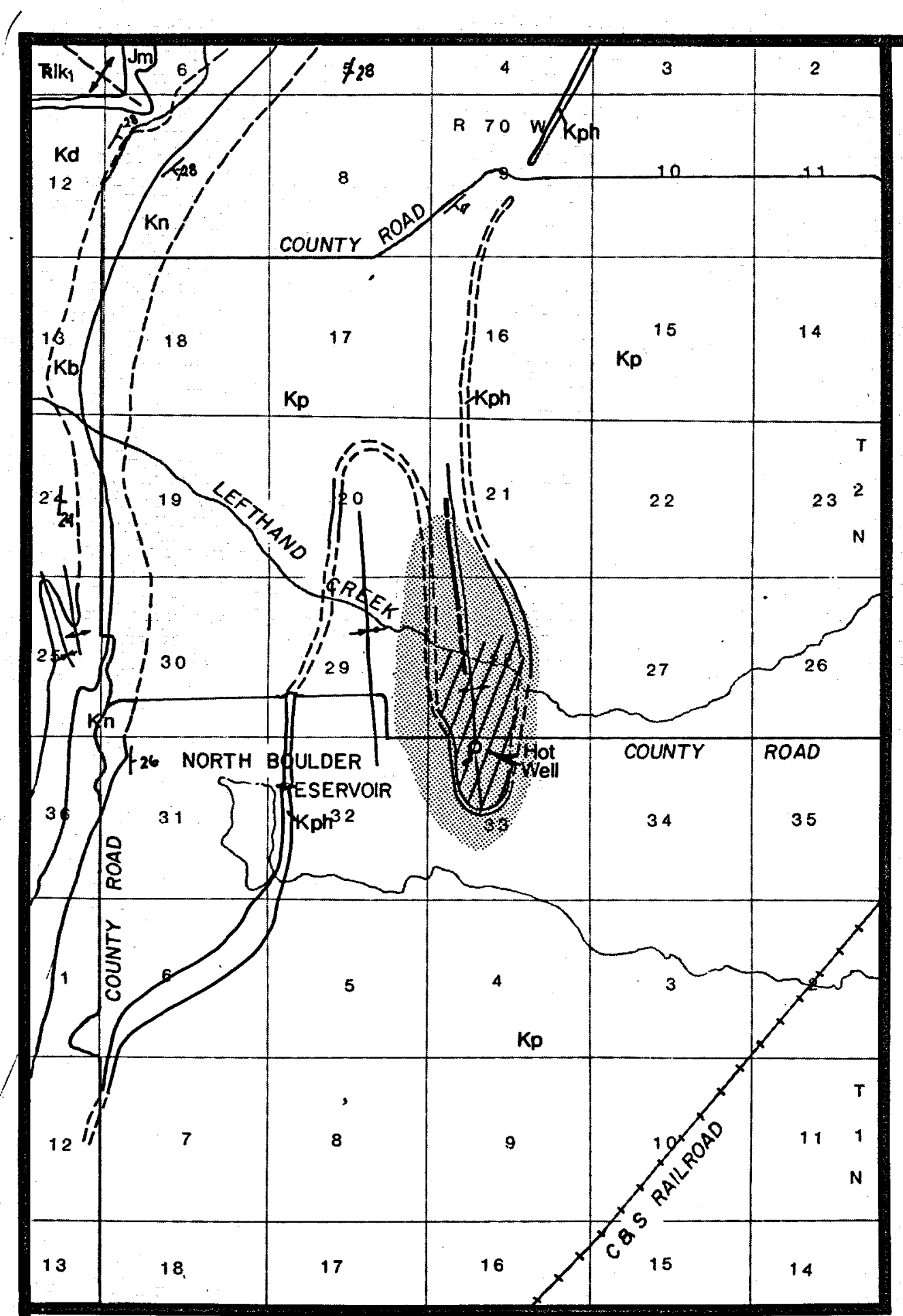

Adapted from Hunter, 1955

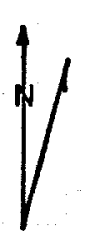

$1 \quad 1 / 2 \quad 0$

1 mile

$1 / / /$ Estimated min. areal $1 / / /$, extent of reservoir

Estimated max. areal extent of reservoir

Figure 8.--Geology of Haystack Butte area and estimated areal extent of the geothermal reservoir. 


\section{\#7 HAYSTACK BUTTE WARM WATER WELL}

LOCATION: Latitude: $40^{\circ} 05^{\prime} 48^{\prime \prime} \mathrm{N}$; Longitude: $105^{\circ} 14^{\prime} 16$ "W.; T. 2 N., R. 70 W., Sec. 33 ba, 6 th P.M.; Boulder County; Niwot 71/2-minute topographic quadrangle map.

GENERAL: This unused oil test hole is located approximately hal fway between Boulder and Longmont. Access is northeast from Boulder on State Highway 119. The well is $650 \mathrm{ft}$ south and $1,550 \mathrm{ft}$ east of the northwest corner of sec. 33 .

Another unused well was located in 1977. This well is located $1,100 \mathrm{ft}$ south and $1,850 \mathrm{ft}$ east of the northwest corner of sec. 33. The well has a temperature of $32^{\circ} \mathrm{C}$ with a discharge of approximately $5 \mathrm{gpm}$.

The Haystack Butte Warm Water well was drilled in 1920 to a total depth of $2,932 \mathrm{ft}$. The well was abandoned due to the large amount of water encountered.

GEOLOGY AND HYDROLOGY: The discharge of this well, which is just seeping around all the material that has been thrown in the well in attempt to plug it, is approximately $4 \mathrm{gpm}$. The waters have a temperature of $28^{\circ} \mathrm{C}$, with $1,200 \mathrm{mg} / 1$ of dissolved solids. The waters are a sodium-bicarbonate type.

As shown on Figure 8 , the well is located on the south end of a faulted anticline. While the fault does not extend as far south as the well, the well is on strike with the fault. The bedrock of the area is the Pierre Shale and with the reported depth of the well, 2,932 ft, it is believed that the waters come from the Dakota Formation, which outcrops a few miles to the west. Recharge probably occurs along the front of the mountains to the west. The source of the heat is unknown; however, a number of Tertiary igneous features dot the mountain front north from Golden (Ralson Butte, Valmont Dike, etc.). These rocks may be too old to supply the needed heat.

GEOTHERMOMETER ANALYSES: Most geothermometers are unreliable when applied to the Haystack Butte Warm Water Well because most of the assumptions inherent in their use are violated. The best estimate of the temperature at depth in this area is probably near $50^{\circ} \mathrm{C}$.

RESOURCE ASSESSMENT: Two estimates of the total energy contained in the reservoir were made. Two different sizes of the reservoir were assumed, one restricted to the crest of the anticline and one encompassing the total anticline (Fig. 8). The small area is estimated to be approximately $0.54 \mathrm{sq}$ $\mathrm{mi}$ in size and contain .0061 Q's of energy. The larger area is estimated to encompass most of the anticline. This area is estimated to encompass an area of $1.5 \mathrm{sq} \mathrm{mi}$ and contain .0169 $\mathrm{Q}^{\prime} \mathrm{s}$ of heat energy (Table 2 ). 


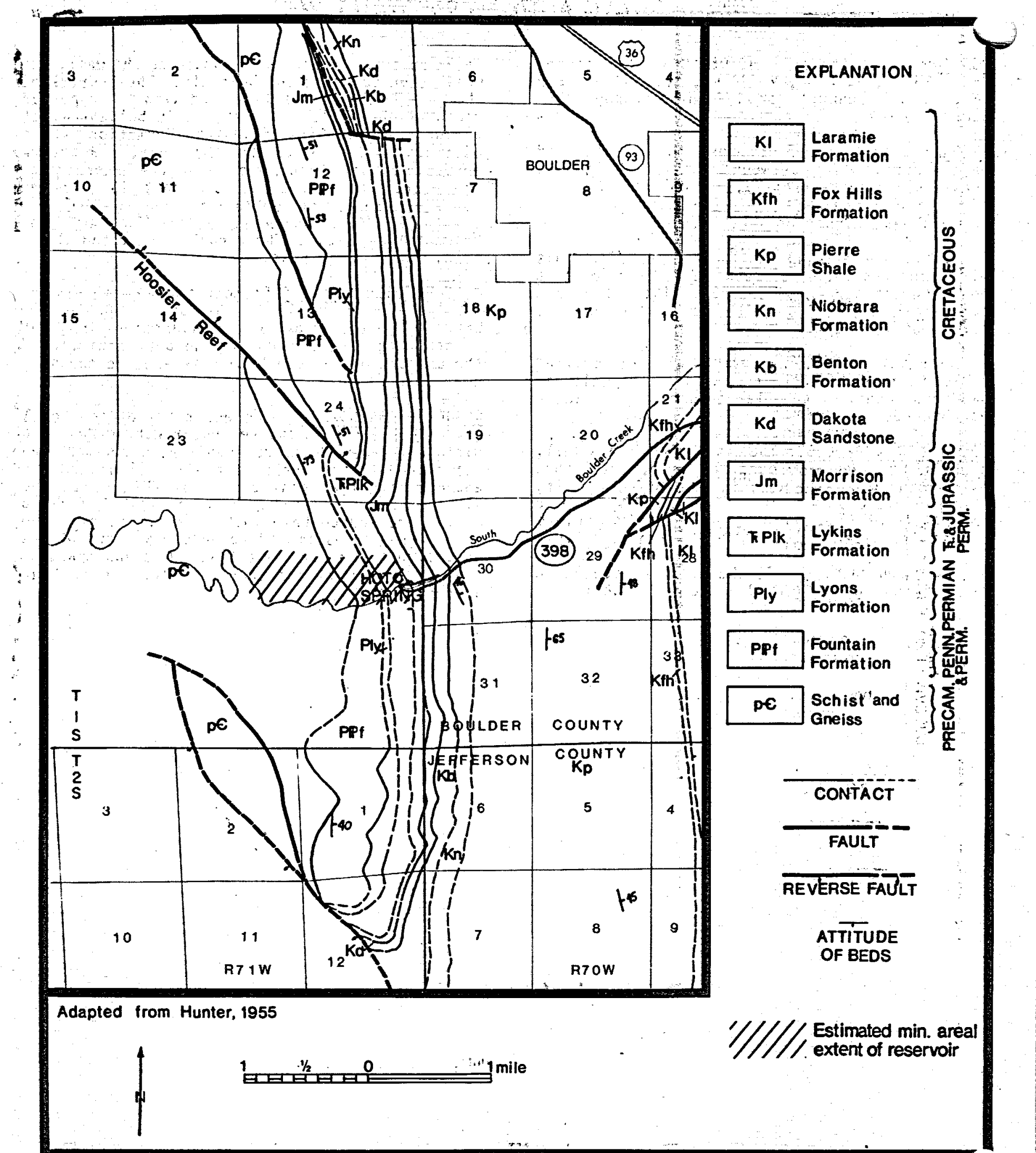

Figure 9.--Map showing the estimated areal extent of the geothermal reservoir and the geologic conditions surrounding Eldorado Springs. 


\section{\#8 ELDORADO WARM SPRINGS}

LOCATION: Latitude: $39^{\circ} 55^{\prime} 52^{\prime \prime}$ N.; Longitude: $105^{\circ} 16^{\prime} 46^{\prime \prime}$ W.: T. 1 S., R. 71 W., Sec 25 da, 6 th P.M.; Boulder County; Eldorado Springs 7 1/2-minute topographic quadrangle map'.

GENERAL: These springs are located approximately I0 miles south of Boulder at the eastern edge of the Front Range. The springs are reached by State Highway 93 from Boulder, then west on State Highway 398.

The springs, which are actually three wells and one spring, are located on both sides of South Boulder Creek. The spring is located in the basement of the large rock and cement building on the north side of the creek west of the swimming pool. The waters from these wells and spring are used in the swimming pool and are bottled and sold commercially.

GEOLOGY AND HYDROLOGY: Throughout the year's time, the temperature of the water ranged from $24^{\circ} \mathrm{C}$ to $26^{\circ} \mathrm{C}$, and the total dissolved solids ranged from 84 to $101 \mathrm{mg} / 1$. Due to the physical layout of the water collection system, it was not possible to measure the discharge of these wells and spring. The waters are a calcium sulfate type.

The waters emerge from South Boulder Creek alluvium, which overlies steeply easterly dipping sandstones of the Fountain and Lyons Formations (Fig. 9). While there are no major faults mapped in the region, it is belleved that the waters originated by deep circulation through fault and fracture zones in the underlying basement rocks of the mountains a few miles to the west.

GEOTHERMOMETER ANALYSES: Geothermometer analys is of the subsurface tempeatures by Barrett and Pearl (1978) determined the following: Chalcedony s 11 ica $21^{\circ} \mathrm{C}$ to $23^{\circ} \mathrm{C}$; Chalcedony mixing model, $26^{\circ} \mathrm{C}$ to $27^{\circ} \mathrm{C}$ with a cold water fraction of 1 to ig percent of the spring flow; $\mathrm{Na}-\mathrm{K}, 254^{\circ} \mathrm{C}$ to $320^{\circ} \mathrm{C}$; $\mathrm{Na}-\mathrm{K}-\mathrm{Ca}$, $43^{\circ} \mathrm{C}$ to $57^{\circ} \mathrm{C}(\mathrm{Tab} / \mathrm{e} 3)^{\circ}$. The $\mathrm{Na}-\mathrm{K}$ estimate is too high because one of the conditions of the model was violated.

The mixing model and silica geothermometer provide a minimum subsurface temperature estimate while the $\mathrm{Na}-\mathrm{K}-\mathrm{Ca}$ geothermometer estimate is probably a maximum val ue of subsurface temperature. Therefore, the subsurface temperature in this area is probabiy between $26^{\circ} \mathrm{C}$ and $40^{\circ} \mathrm{C}$ (Table 3 ).

RESOURCE ASSESSMENT: Based on the above assessment of the geologic conditions of the area, it is assumed that the reservoir extends to the west of the spring and encompasses an area of approximately. $.50 \mathrm{sq} m i$ and contained .0147 Q's of energy (Table 2). 


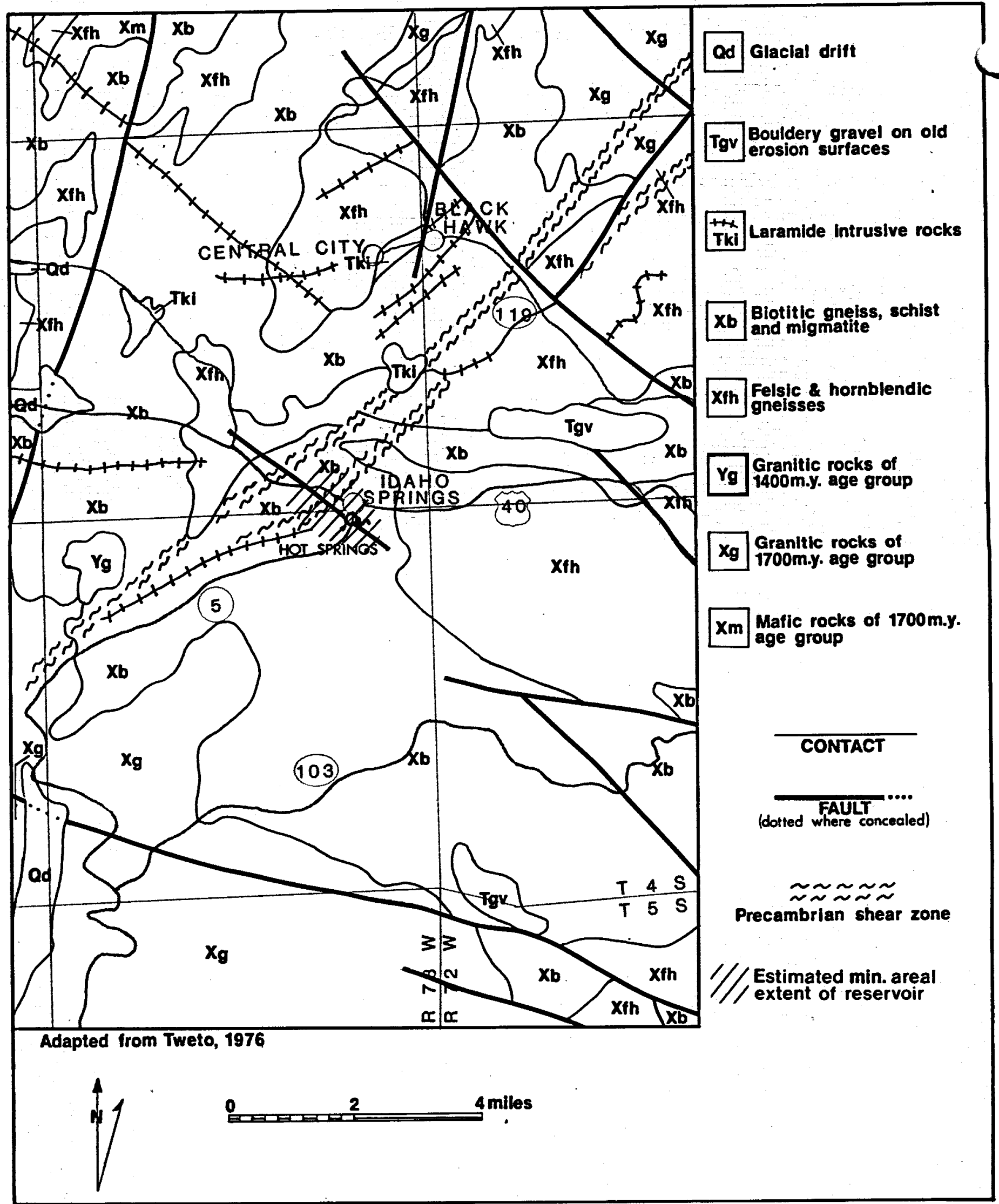

Figure 10.--Geology surrounding Idaho Springs and estimated geothermal reservoirs extent. 


\section{\#9 IDAHO HOT SPRINGS}

LOCATION: Latitude: $39^{\circ} 44^{\prime} 20^{\prime \prime} \mathrm{N}$.; Longitude: $105^{\circ} 30^{1} 43^{\prime W}$.; T. 4 S., R. 73 W., Sec 1 ba, 6 th P.M.; Clear Creek County; Idaho Springs 7 1/2-minute topograpnhic quadrangle map.

GENERAL: This group of three thermal springs and one well are located along Soda Creek at the Indian Springs Lodge on the south side of the town of Idaho Springs. The waters from the springs and well are used for baths and swimming purposes.

GEOLOGY AND HYDROLOGY: The temperatures of the waters range from a Tow of $20^{\circ} \mathrm{C}$ to a high of $46^{\circ} \mathrm{C}$. The discharge varies from $1 \mathrm{gpm}$ to $30 \mathrm{gpm}$.

Spring A: located in a tunnel $75 \mathrm{ft}$ south of the lodge, and east of the creek. During the year the temperature of the water ranged from $40^{\circ} \mathrm{C}$ to $45^{\circ} \mathrm{C}$. The spring had a discharge of $21 \mathrm{gpm}$ and total dissolved solids in the water varied from 1,940 to $2,110 \mathrm{mg} / 1$. The waters are a sodium-bicarbonate type.

Spring B: This spring is located $50 \mathrm{ft}$ east of the southeast corner of the lodge in a tunnel in the cliff face. The spring has a temperature of $24^{\circ} \mathrm{C}$, a discharge of less than one $\mathrm{gpm}$ and the total dissolved solids in the water is $1,070 \mathrm{mg} / 1$ of a sodium-bicarbonate type.

Spring C: This spring is located in a tunnel $100 \mathrm{ft}$ south of the lodge. When measured, the spring had a temperature of $20^{\circ} \mathrm{C}$, a discharge of one $\mathrm{gpm}$, and total dissolved mineral matter of $1,070 \mathrm{mg} / 1$ in waters of a sodium-bicarbonate type.

Lodge Hot Water We11: This well, located at the south end of the swimming pool at the north end of the lodge, has a temperature of $46^{\circ} \mathrm{C}$ and a discharge of $30 \mathrm{gpm}$. The water contains $2,070 \mathrm{mg} / 1$ of total dissolved solids and is a sodium-bicarbonate type.

The following brief description of the geological history of the Idaho Springs region is taken from Harrison and Wells (1959), Lovering and Goddard (1950), and Moench and Drake (1966).

The Idaho Hot Springs are located within the Colorado Mineral Belt. The Mineral Belt is a northeast-trending zone of intrusive rocks and hydrothermal veins of early Tertiary age. The bedrock of the area is composed largely of layered Precambrian gneissic rocks, the Idaho Springs Formation, and small bodies of granite and pegmatite.

Unfortunately, none of the various reports published on the Idaho Springs area describes in any detail the geological conditions surrounding the hot springs. As noted on Figure 10, the hot springs are located on the trace of a northwest-trending fault cutting Precambrian metamorphic rocks of the Idaho Springs Formation.

The origin of the hot springs is unclear, but they are believed to be due to deep circulation of ground waters through fracture and fault zones within the basement complex. Reiter (1975) has shown Idaho Springs to have a heat flow of 2.0 heat flow units.

\section{GEOTHERMOMETER ANALYSES}

Conclusion: Geothermometer models should be used with caution when applied to the Idaho Hot Springs because most of the assumptions inherent in their use are violated.

Due to the extensive modification of the natural springs for bathing purposes, the following geothermometer analys is will be based on data from the Lodge Hot Water Well. Cristobalite silica geothermometer yields a estimated temperature of $59^{\circ} \mathrm{C}$; Cristobalite Mixing Model yielded a temperature estimate of $81{ }^{\circ} \mathrm{C}$ with a cold-water fraction of 48 percent; and $\mathrm{Na}-\mathrm{K}$ and $\mathrm{Na}-\mathrm{K}-\mathrm{Ca}$ geothermometer yielded estimated temperatures of $231^{\circ} \mathrm{C}$ and $210^{\circ} \mathrm{C}$ respectively (Table 3 ) (Barrett and Pearl, 1978).

The estimation of subsurface temperature for this area is unreliable due to the ambiguous geochemistry of the thermal waters.

RESOURCE ASSESSMENT: Since Barrett and Pearl T1978) postulated that the springs were associated with fault and fracture zones the boundaries of the reservoir area were drawn to include those zones (Fig. 10). It is estimated that the areal extent of the reservoir includes $1.52 \mathrm{sq} \mathrm{mi}$. Calculations show that this system could contain .1714 Q's of energy at a maximum temp. of $80^{\circ} \mathrm{C}$ (Table 2$)$. 


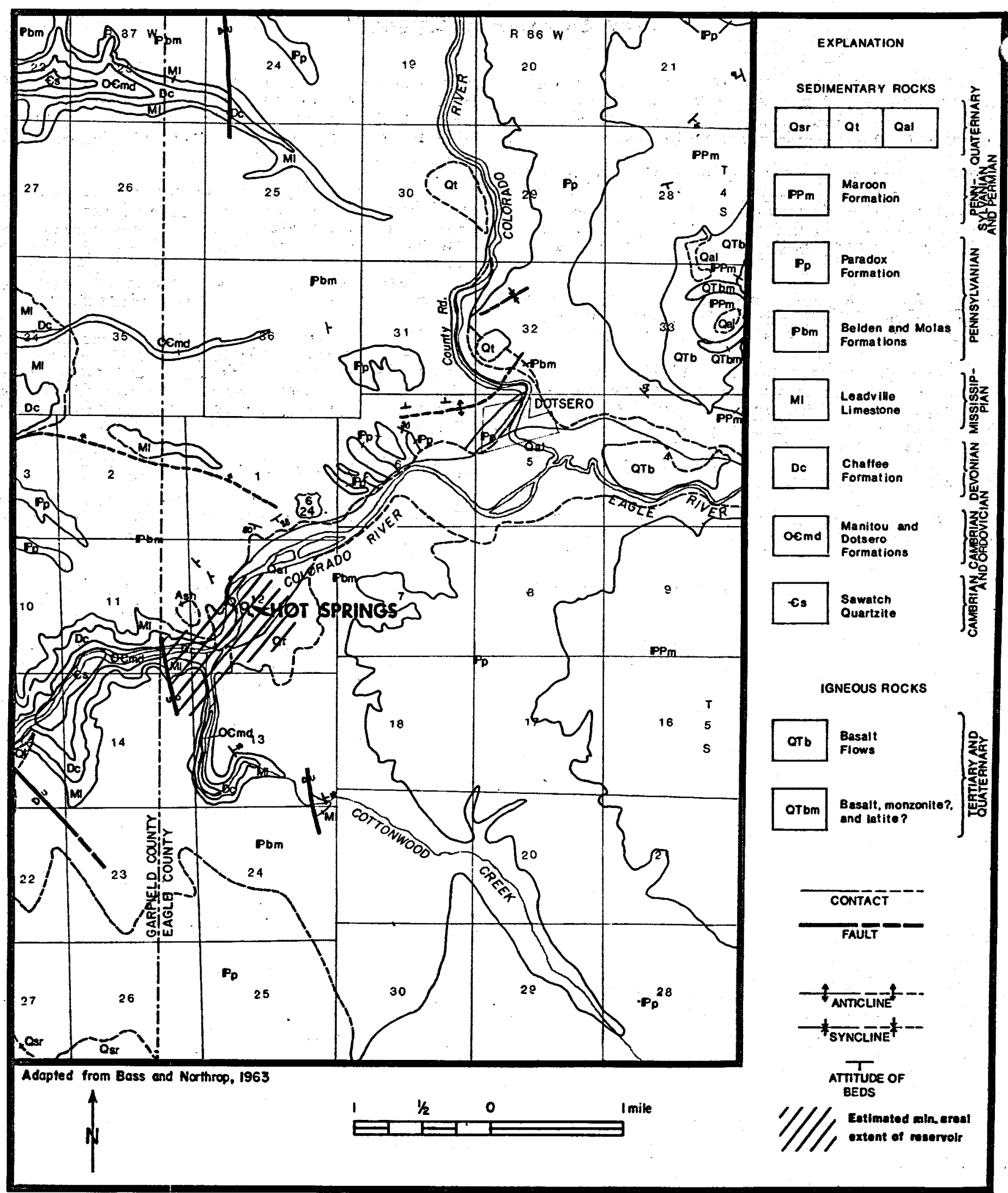

Figure 11.--Map showing estimated areal extent of the geothermal reservoir and geologic conditions surrounding Dotsero Hot Springs. 


\section{\#10 DOTSERO WARM SPRINGS}

LOCATION: Latitude: $39^{\circ} 37^{\prime} 39^{\prime \prime N}$.; Longitude: $107^{\circ} 06^{\prime 2} 21 "$; T. 5 S., R. 87 K., Sec. 12 bd, 6th P.M.; Eagle County; Glenwood Springs 15-minute topographic quadrangle map.

GENERAL: This group of unused springs is located on both sides and in the Colorado River approximately 0.5 mile upstream from where the river bends before entering Glenwood Canyon and approximately 3 miles downstream from the confluence of the Colorado and Eagle Rivers. The springs on the west side of the river are located approximately $150 \mathrm{yd}$ north of the house and flow out from under U.S. Highways 6 and 24 at the level of the Colorado River. About 5 springs comprise the group.

The springs on the south side of the river are located at the bend of the river. Access to these springs is either by a bridge a couple miles down the river or by a foot bridge several miles upriver.

GEOLOGY AND HYOROLOGY: Due to the spring's high flow, and the near submergence of the springs by the river, one cannot accurately measure the discharge of either groups of springs. Depending upon the time of year, the discharge of the springs on the west side varies between 500 and $800 \mathrm{gpm}$. The discharge of the springs on the southeast side of the river was estimated to be $1,000 \mathrm{gpm}$. Haters from both groups contained approximately 10,000 $\mathrm{mg} / 1$ of dissolved solids, and the waters are a sodium-chloride type. The temperature of both spring groups was $32^{\circ} \mathrm{C}$ (Barrett and Pearl, 1978).

While the springs emerge from the Colorado River alluvium, which overlies the Belden shale (Fig. 11), it is belfeved that the waters actually come from the nearby Leadville Limestone. These springs may be fault controlled, for just to the north of the springs there is an abrupt change in direction of dip from northeast to southwest. If the fault which occurs south of the spring were to be continuous in the subsurface to the north it would pass close to the spring and the area where the dips reverse.

Recharge probably occurs where the Leadville LImestone crops out to the north and west along the flanks of the White River Uplift. The source of heat is unknown but may be related to the volcanic rocks capping the White River Uplift. Thermal waters found around the White River Uplift at Glenwood Springs, Dotsero, Yampa (reported hot-water well), Steamboat Springs and. Routt Springs, leads one to postulate that a residual heat source remains in association with the White River Uplift. Volcanic rocks that were erupted approximately 4,000 years ago are found approximately one mile east of the confluence of the Colorado River and the Eagle River (Grose, 1974). Another possible source of the heat could be elevated geothermal gradients in the area (Barrett and Pearl, 1978).

GEOTHERMOMETER ANALYSES: Barrett and Pearl (1978) stated that analysis suggests that quartz or chalcedony may control the silica content of the warm springs. The chalcedony-silica geothermometer yields a subsurface temperature estimate of $16^{\circ} \mathrm{C}$, which is obviously incorrect because it is below the surface temperature of the warm springs $\left(31^{\circ} \mathrm{C}\right.$ to $32^{\circ} \mathrm{C}$ ) (Table 3 ). The quartz-silica geothermometer estimate of subsurface temperature is $45^{\circ} \mathrm{C}$ to $47^{\circ} \mathrm{C}$. The chalcedony mixing model yields a temperature estimate of $27^{\circ} \mathrm{C}-29^{\circ} \mathrm{C}$ with a cold-water fraction of 26 to 36 percent of the spring flow. The quartz mixing model yields a subsurface temperature estimate of $74^{\circ} \mathrm{C}$ to $76^{\circ} \mathrm{C}$ with a cold-water fraction of 65 to 67 percent of the spring flow. The reliability of both the quartz and chalcedony mixing models is questionable because the silica contents of the warm springs are well below the minimum conditions specified for the application of this geothermometer.

Calculations by Barrett and Pearl (1978) showed that the $\mathrm{Na}-\mathrm{K}$ and $\mathrm{Na}-\mathrm{K}-\mathrm{Ca}$ geothermometers yield subsurface temperature estimates of $102^{\circ} \mathrm{C}$ to $135^{\circ} \mathrm{C}$ and $109^{\circ} \mathrm{C}$ to $144^{\circ} \mathrm{C}$, respectively.

Conclusion: The extremely high flow (greater than $1,500 \mathrm{gpm}$ of this group suggests very little difference between the surface temperature of these springs and the temperature at depth. Therefore, the likely subsurface temperature in this area is between $32^{\circ} \mathrm{C}$ and $45^{\circ} \mathrm{C}$ (Table 3 ).

RESOURCE ASSESSMENT: The reservoir is estimated to extend from the small fault southwest of the spring and to the area of the projected fault to the north. This area encompasses approximately $0.5 \mathrm{sq}$ mi and may contain .0045 $Q^{\prime} s$ of heat energy at an average temperature of $39^{\circ} \mathrm{C}$ (Table 2 ). 


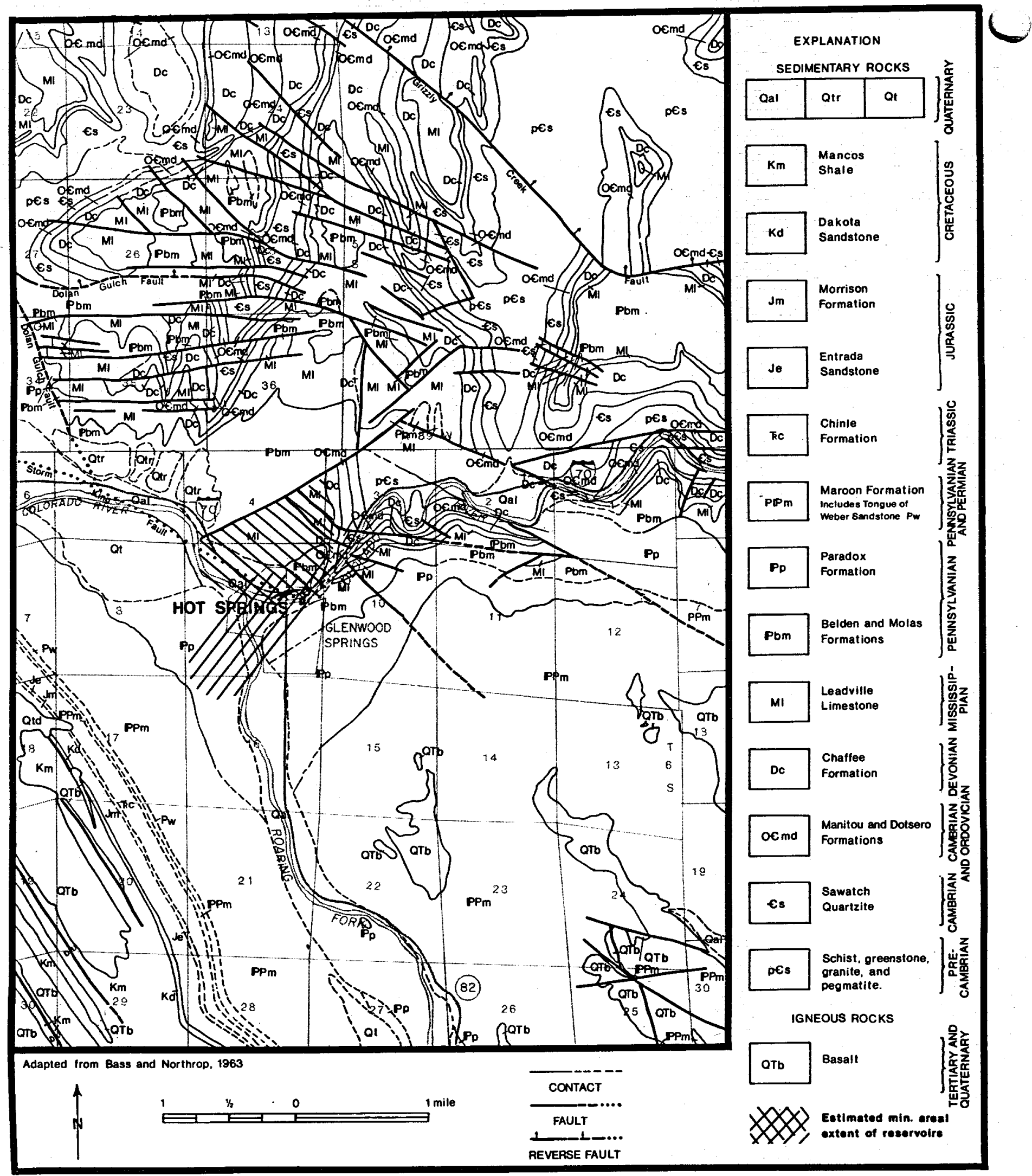

Figure 12.--Geologic map of Glenwood Springs and surrounding region and estimated areal extent of the geothermal reservoir. 


\section{\#11 GLENWOOD HOT SPRINGS}

LOCATION: Latitude: $39^{\circ} 32^{\prime} 59^{\prime \prime} \mathrm{N}$; Longitude: 107019'18"W.; T. 6 S., R. 89 W., Sec. 9 ad, 6 th P.M.; Garfield County; Glenwood Springs 7 1/2minute topographic quadrangle map.

GENERAL: The 12 to 15 springs collectively known as Glenwood Springs are located in and adjacent to the community of Glenwood Springs along the Colorado River on Interstate $H i$ ghway 70 in western Colorado. These springs are located along both banks of and in the Colorado River from a point approximately 0.5 to 0.75 mile east of the canyon mouth to the west edge of Glenwood Springs. The waters from the springs are used for swimming and medicinal purposes.

\section{South Side of River from East to West}

Railroad Spring: Located approximately 0.75 mile west of the westernmost tunnel on the railroad, approximately 0.5 to 0.75 mile east of the canyon mouth. The spring, which is located just at the water line of the river, has a discharge of $75 \mathrm{gpm}$, a temperature of $51^{\circ} \mathrm{C}$, and contains $18,400 \mathrm{mg} / 1$ of total dissolved solids.

Spring D: Located approximately $250 \mathrm{ft}$ east of the siphon pipes crossing the river below the cliffs. This spring has a discharge of $74 \mathrm{gpm}$, a temperature of $50^{\circ} \mathrm{C}$, and contains $18,000 \mathrm{mg} / 1$ of total dissolved solids.

Spring C: Located $170 \mathrm{ft}$ east of the siphon pipe. This spring has a discharge of 2 to $3 \mathrm{gpm}$, a temperature of $46^{\circ} \mathrm{C}$. The spring was not sampled for dissolved mineral matter.

Spring B: Located $27 \mathrm{ft}$ west of the siphon, this spring has a discharge ranging from 75 to 110 gpm with a temperature of $49^{\circ} \mathrm{C}$ and contains 17,700 to $18,400 \mathrm{mg} / \mathrm{l}$ of total dissolved solids.

Spring A: This spring is located $480 \mathrm{ft}$ west of siphon and has a discharge of 2 to $3 \mathrm{gpm}$ with a temperature of $44^{\circ} \mathrm{C}$ and contains $17,600 \mathrm{mg} / 1$ of total dissolved solids.

River Springs: Located about $50 \mathrm{ft}$ out into the Colorado River, directly north of Spring $A$, are two large boulders of Leadville Limestone. Hot Springs issue from these boulders with discharges of about $10 \mathrm{gpm}$ and $50 \mathrm{gpm}$. The temperature of the springs nearest to the shore were $50^{\circ} \mathrm{C}$. These springs were not sampled for dissolved mineral matter.

\section{North Side of River, from East to West}

The Vapor Caves Springs are located at the canyon mouth in the Vapor Caves building. The discharge of the spring in the men's side was estimated at $5 \mathrm{gpm}$, the temperature was $50^{\circ} \mathrm{C}$, and the total dissolved solids were $18,000 \mathrm{mg} / \mathrm{l}$. A fong sulfur dioxide gas content in the spring is pparent for it takes your breath away when you enter the tunnel.
Big Spring (also called Yampa Spring) is located approximately 75 yd to the east of the swimming pool. The waters from this spring are used in the swimming pool. The spring has a discharge of $2,263 \mathrm{gpm}$ with a temperature of $50^{\circ} \mathrm{C}$ and contains $20,200 \mathrm{mg} / \mathrm{l}$ of total dissolved solids.

Drinking Spring: located approximately $100 \mathrm{ft}$ east of the swimming pool. The spring has a discharge of 140 to $161 \mathrm{gpm}$ with a temperature of $50^{\circ} \mathrm{C}$ to $51^{\circ} \mathrm{C}$, and contains 18,800 to $20,500 \mathrm{mg} / \mathrm{l}$ of total dissolved solids.

Graves Spring is located at 0281164 Road in T. 6 S., R. 89 W., Sec. 9 bb, 6th P.M. south and west of the State Highway buildings. This spring is located under the front porch of Dr. Charles Graves' chiropractic office. The discharge of this spring is $5 \mathrm{gpm}$ with a temperature of $46^{\circ} \mathrm{C}$ and contains $21,500 \mathrm{mg} / 1$ of total dissolved solids. A number of other hot springs in the immediate vicinity were not sampled.

All of the above springs are a sodium-chloride type with a high concentration of sulfate:

While all the springs issue from alluvial deposits along the Colorado River, it is believed that the waters migrate up from depth through the underlying Leadville Limestone. The Leadville Limestone is very porous and permeable as evidenced by the large solution caves present at the canyon mouth on the south side.

Glenwood Springs are located at the west end of Glenwood Canyon and on the south flank of the White River Uplift. Rocks from Precambrian to Mississippian in age are exposed in the canyon just a few miles to the east. As shown on Fig. 12, the area to the north and east of the springs is cut by many faults.

One of the major faults that may control the occurrence of the hot springs is the northwest-trending Storm King Fault. Although it has not been proven that this fault actually extends as far east as the hot springs, Bass and Northrop (1963) have projected it to the spring area. While this fault may be the controlling factor for this thermal spring, Galloway (personal communication, 1978) has shown, based on evidence presented by Bass and Northrop (1963), that the ascending Leadvilie limestone intersects the surface at the site of the springs. According to Galloway's hypothesis, the springs result from deep circulation and up dip flow of heated waters in the Leadville limestone and that the recharge area is probabiy somewhere to the southwest.

One of the unexplained circumstances regarding this group of springs is the origin of the sulfate ions found in the water. The Leadville Limestone and underlying formations consist of limestones, sandstones, and some thin shale units. If the thermal waters moved only through these formations, no sulfate minerals would be dissolved since these 
units do not contain any large amounts of sulfate-bearing minerals. Overlying the Leadville Formation are the red beds of the Maroon Formation and its lateral equivalents, the Eagle Valley Evaporite. These units do contain large amounts of sulfate-bearing minerals. Therefore, from the mineralogy of the thermal waters, it appears that at some point they contact the Maroon Formation. The hydrology of this system appears to be quite complex and must be studied in further detail.

GEOTHERMOMETER ANALYSES: Silica solubility and temperature relationships suggest that temperature-dependent equilibration between the thermal water and chalcedony may control the silica content of the hot springs (Table 3 ) (Barrett and Pearl , 1978). The chalcedony-silica geothermometer estimate of subsurface temperature is $44^{\circ} \mathrm{C}$ to $51^{\circ} \mathrm{C}$, which is nearly identical to the surface temperature of the hot springs in this area $\left(46^{\circ} \mathrm{C}\right.$ to $51^{\circ} \mathrm{C}$ ). Chalcedony mixing model analysis yields a subsurface temperature estimate of $49^{\circ} \mathrm{C}$ to $77^{\circ} \mathrm{C}$, with a cold-water fraction of 0 to 46 percent of the spring flow.

Barrett and Pearl (1978) stated that the presence of extensive travertine deposits in the vicinity (T. 6 S., R. 89 W. Sections 3, 4, 5, 9, 10) and travertine-depositing springs (Springs $B$ and $D$, Railroad Hot Springs and others) suggest that the $\mathrm{Na}-\mathrm{K}$ and $\mathrm{Na}-\mathrm{K}-\mathrm{Ca}$ geothermometer estimates $\left(129^{\circ} \mathrm{C}\right.$ to $168^{\circ} \mathrm{C}$ and $143^{\circ} \mathrm{C}$ to $186^{\circ} \mathrm{C}$, respectively) are too high. In addition, the extremely high sodium, chloride, calcium, magnesium, and sulfate contents of the hot springs suggest that the ascending thermal water encounters the Eagle Valley
Evaporite at depth (Bass and Northrop, 1963) further raising the geothermometer estimates.

Conclusion: The extremely high flow ( $3000 \mathrm{gpm}$ ), and excellent agreement between the chalcedony-silica and the mixing models with the silica content and surface temperature of the hot springs suggest that the temperature at depth is probably not much higher than the surface temperature of the hot springs. However, the geochenistry of these thermal waters is too complex for accurate prediction of subsurface temperature.

RESOURCE ASSESSMENT:

Ga110way

(personal communication, 1978) has shown that the spurce of the heat may be due to deep circulation within the Leadvilie Limestone. Bass and Northrop (1963) have shown that the Leadville Limestone dips steeply to the southwest and reaches a depth in excess of $20,000 \mathrm{ft}$ within 4 miles of Glenwood Springs. If this is the case, then the spring's occurrence is due to up dip flow of hot water in the Leadville Limestone and reaches the surface at its present location. Faulting may be a secondary controlling factor.

As there is a possibility that the waters could be coming from one of two directions, two estimates of the reservoirlextent were made. One estimate considered that the waters could be related to the faulting north of town and the other estimate that the waters are moving up dip from the south-southwest. The northern reservoir has an estimated aeral extent of $1.32 \mathrm{sq}$ mi and contains $.0279 Q^{\prime}$ s of energy. The southern reservoir has an estimated areal extent of approximately $0.50 \mathrm{sq} \mathrm{mi}$ and contains .0106 Q's of energy (Table 2). 


\section{\#12 SOUTH CANYON HOT SPRINGS}

LOCATION: Latitude: $39^{\circ} 33^{\prime} 16^{\prime \prime}$.; Longitude: $107^{\circ} 23^{\prime} 53^{\prime \prime W}$.; T. 6 S., R. 90 W., Sec. $2 \mathrm{~cd}, 6$ th P.M.; Garfield County; Storm King Mountain 7 1/2-minute topographic quadrangle map.

GENERAL: This small group of unused springs is Tocated 0.5 mile south of Interstate Highway 70 in South Canyon west of Glenwood Springs.

There are three distinct springs or seeps in this group. Spring A, which is the largest, is actually the discharge of three small springs that flow together. Spring B lies approximately $75 \mathrm{ft}$ east of $A$, and Spring $C$ is located $5 \mathrm{ft}$ upstream from the footbridge crossing the creek. Waters from $A$ and $B$ are piped to the pool for bathing purposes. Waters from Spring $C$ are unused.

\section{GEOLOGY AND HYDROLOGY:}

Spring A: Temperature: $48^{\circ} \mathrm{C}$; Discharge 7 to 17 gpm; Total dissolved solids: 772-800 mgl; Water type: sodium-bicarbonate.

Spring B: Temperature: $48^{\circ} \mathrm{C}$; Discharge est.: 1 gpm; Total dissolved sol ids: $757 \mathrm{mg} / 1$; Water type: sodium-bicarbonate.
Spring C: Temperature: $49^{\circ} \mathrm{C}$; Discharge: $6 \mathrm{gpm}$.

These waters dischare from the Dakota Formation along the Grand Hogback. As shown on the geologic map (Fig. 13). The occurrence of these thermal springs is peculiar because there are no nearby faults or folds. The springs probably represent deep circulation through the Dakota Formation in an area of high geothermal gradient.

GEOTHERMOMETER ANALYSES: Geothermometer model analysis yields the following subsurface temperatures: Chalcedony silica $60^{\circ} \mathrm{C}$ to $67^{\circ} \mathrm{C}$; Mixing model $103^{\circ} \mathrm{C}$ to $127^{\circ} \mathrm{C}$ with a cold water fraction of 60 to 80 percent; and $\mathrm{Na}-\mathrm{K}$, and $\mathrm{Na}-\mathrm{K}-\mathrm{Ca}$ model $137^{\circ} \mathrm{C}$ to $140^{\circ} \mathrm{C}$ and $135^{\circ} \mathrm{C}$ to $137^{\circ} \mathrm{C}$, respectively (Table 3 ) (Barrett and Pearl, 1978).

Considering the precision of the geothermometer models suggests that reservoir temperatures in this area are between $100^{\circ} \mathrm{C}$ and $130^{\circ} \mathrm{C}$.

RESOURCE ASSESSMENT: The areal extent of the reservoir is estimated to be 0.1 sq mi (Fig. 13). A reservoir of this size could contain .0021 Q's of heat energy at an average maximum temperature of $75^{\circ} \mathrm{C}$ (Tabie 2). 


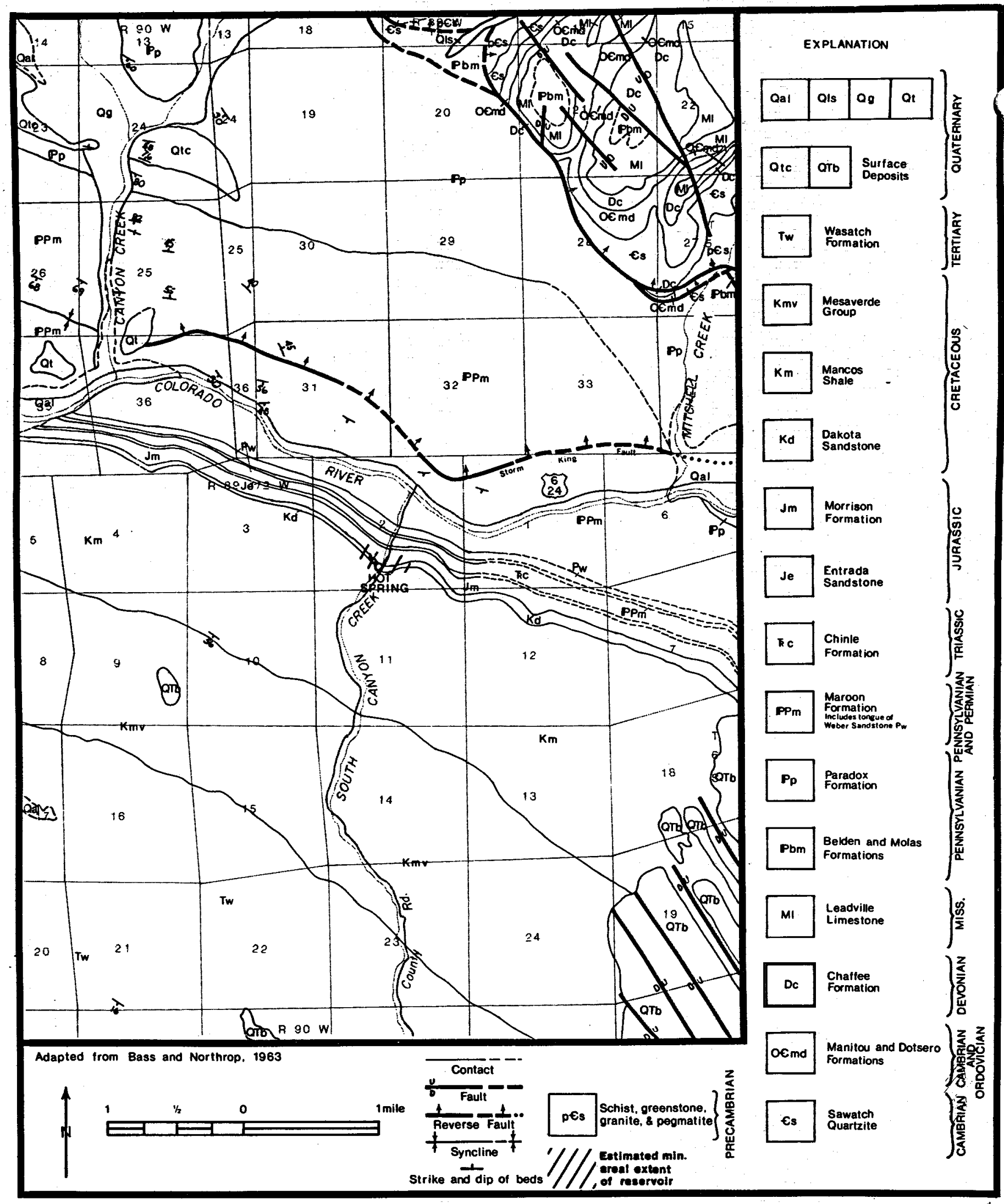

Figure 13.--Map showing estimated extent of the South Canyon Hot Springs geothermal reservoir and the surrounding geologic conditions. 


\title{
\#13 PENNY HOT SPRINGS
}

\author{
(AVALANCHE HOT SPRINGS)
}

LOCATION: Latitude: $39^{\circ} 13^{\prime} 33^{\prime \prime} \mathrm{N}_{\text {; }}$ L Longitude: $107^{\circ} 1328$ "W.; T. 10 S., R. 88 W., Sec. 4 ba, 6 th P.M.; Pitkin County; Redstone 7 1/2-minute topographic quadrangle map.

GENERAL: This large group of hot springs extends for over 0.5 mile along both banks of the Crystal River approximately 3 miles north of Redstone and 13.5 miles south of Carbondale on State Highway 133. With the exception of one small spring, which is used in a small greenhouse, the thermal waters are unused.

GEOLOGY AND HYDROLOGY: Only two springs, the Penny and the Granges Springs, were sampled and measured. The temperature of Penny Hot Springs, which is located on the south side of the river, varied from $40^{\circ} \mathrm{C}$ to $46^{\circ} \mathrm{C}$ throughout a year's time, while its discharge remained constant at $10 \mathrm{gpm}$. The waters contained 2,750 to $2,820 \mathrm{mg} / 1$ of dissolved solids and are a mixed calcium-sodium sulfate type.

Granges Spring, located on the north side of the river, has a discharge of $12 \mathrm{gpm}$, a temperature of $56^{\circ} \mathrm{C}$, total dissolved solids of $2,960 \mathrm{mg} / 1$, and the waters are a calcium-sodium sulfate type. This spring was sampled during a period of low river flow, and the samples were collected from the edge of the spring pool. The Penny Spring sampling point is $50 \mathrm{ft}$ south of a wooden fence-like structure in the field.

The geologic map (Fig. 14) of the Penny Hot Springs area shows that the waters ascend through Crystal River alluvium overlying the Pennsylvanian Maroon Formation. While the upper springs are associated with the Maroon Formation, the lower springs may be associated with a large Tertiary intrusive. It is believed that waters from all springs are associated with the intrusive body. While no faults are shown on the geologic map, the intrusive body is cut by numerous faults and fractures. These features do not continue into the overlying sedimentary formations. It ts believed that the waters ascend from depth along these faults and fractures. Recharge probably occurs in the high area to the northwest with the waters moving downdip in the sedimentary formations and then up the fractures in the intrusive.

GEOTHERMOMETER ANALYSES: When applied to Penny Hot Springs, most of the assumptions inherent in the use of the geothermometer models are violated. Therefore, they must be used with caution. Amorphous silica geothermometer yields an est imated reservoir temperature of $3^{\circ} \mathrm{C}$ to $39^{\circ} \mathrm{C}$; the Amorphous Silica Mixing Model yields a temperature estimate of $35^{\circ} \mathrm{C}$ to $45^{\circ} \mathrm{C}$ with a cold water fraction of 2 to 50 percent. The $\mathrm{Na}-\mathrm{K}$ and $\mathrm{Na}-\mathrm{K}-\mathrm{Ca}$ geothermometers yield subsurface temperatures of $197^{\circ} \mathrm{C}$ and $202^{\circ} \mathrm{C}$ and $89^{\circ} \mathrm{C}$ to $93^{\circ} \mathrm{C}$, respectively (Table 3) (Barrett and Pearl, 1978).

The Na-K-Ca geothermometer and the Amorphous Silica Mixing Model provide maximum and minimum estimated subsurface temperatures, respectively. The reservoir temperature in this area is probably between $60^{\circ} \mathrm{C}$ and $90^{\circ} \mathrm{C}$ (Table 3$)$.

RESOURCE ASSESSMENT: The areal extent of the reservoir was estimated to include all of the intrusive rock body plus some of the adjoining rocks. Since there is another intrusive rock body approximately $1 \mathrm{mile}$ to the northwest (Fig. 14) the reservoir boundaries were drawn to include this area also. : The Penny Hot Spring fractured reservoir is estimated to contain between .1664 Q's and .486 Q's. 


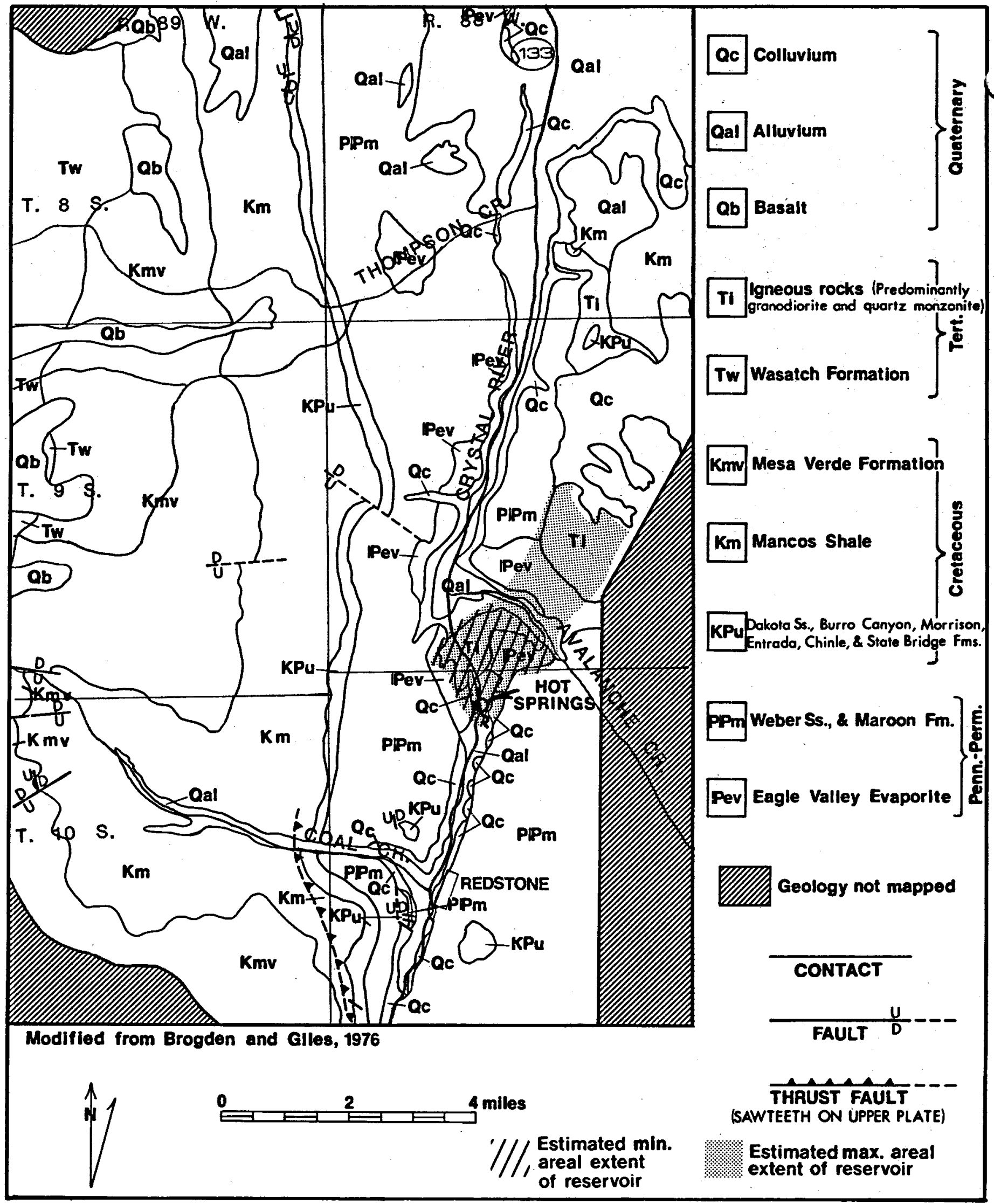

Figure 14.--Penny Hot Springs, geology and estimated areal extent of the reservoir. 


\section{\#14 COLONEL CHINN HOT WATER WEL}

LOCATION: Latitude: $38^{\circ} 52^{\prime} 23^{\prime \prime} \mathrm{N}$.; Longitude: $107^{\circ} 38^{\prime} 04^{\prime \prime W . ;}$ T. 14 S., R. 92 W., Sec. 14 add, 6 th P.M.; Delta County; Paonia 7 1/2-minute topographic quadrangle map.

GENERAL: This well is located southwest of Paonia, Colorado, on Stewart's Mesa.. The well is approximately 2.25 miles from Paonia on a paved county road and 0.25 mile south of the curve in the road where the road tops the mesa and heads due south.

GEOLOGY AND HYOROLOGY: The well is reported to be $4,499 \mathrm{ft}$ deep, and the waters have a surface temperature of $42^{\circ} \mathrm{C}$. While the total dissolved solids were not determined, the conductance was 3,560 micromhos.

As noted on Figure 15 the geological conditions of the area appear very simple. Stewart's Mesa is an erosional geomorphic feature capped with alluvial sand and gravel deposits. The bedrock of the area is the black shale of the Mancos Formation. The thermal waters may come from the Dakota Formation which underlies the Mancos shale. Hall (1972) mapped the Dakota Sandstone as having uniform north dip from the outcrop area approximately 9 miles south of the well. It is believed that the waters found in this well are being recharged at the outcrop area along the Smith Fork and then migrate downdip to the north. Their elevated temperatures probably arise from high geothermal gradients in the area due to a Tertiary intrusive located 5 miles to the Southeast.
GEOTHERMOMETER ANALYSES: Calculation of the silica solubility and temperature relationships shows that the chalcedony-silica geothermometer is applicable (Barrett and Pearl, 1978). This model yields a subsurface temperature estimate of $41^{\circ} \mathrm{C}$. Chalcedony mixing model analysis yields a subsurface temperature estimate of $43^{\circ} \mathrm{C}$ with a cold water fraction of 1 percent of the total flow (Table 3 ).

The Na-R and Na-K-Ca geothermometers yield subsurface temperature estimates of $183^{\circ} \mathrm{C}$ and $170^{\circ} \mathrm{C}$, respectively. These results are unreliable due to the low discharge (5 gpm) and low temperature $\left(42^{\circ} \mathrm{C}\right)$ of the artesian wel1. Moreover, the high magnesium content of the thermal waters further reduces the reliability of these models (Barrett and Pearl, 1978).

Conclusion: The mixing model and the silica geothermometers imply that the temperature at depth is near the surface temperature of the artesian wel1. However, the ambiguous nature of the geochemistry of these waters is such that no reliable subsurface temperature estimates are possible.

RESOURCE ASSESSMENT: In light of the uncertainty regarding the areal extent of the reservolr it was estimated to be restricted to an area of $7.55 \mathrm{sq} \mathrm{mi}$ around the well. If this estimate ts correct, the reservoir could contain .01810 s of heat energy with an average temperature of $51^{\circ} \mathrm{C}$ (Tabie 2). 


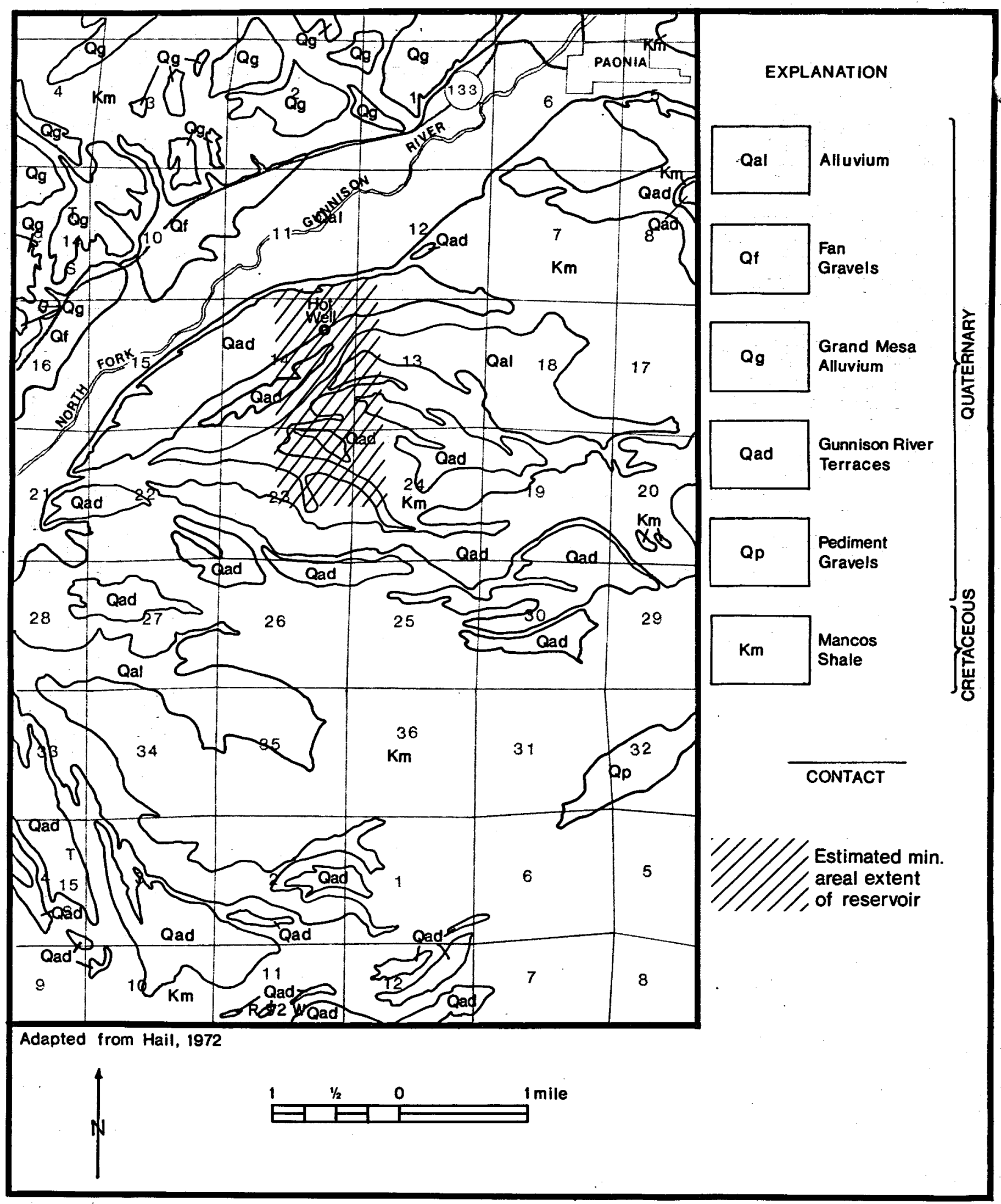

Figure 15.--Map showing geologic conditions surrounding Colonel Chinn Water Well and estimated areal extent of reservoir. 


\section{\#15 CONUNDRUM HOT SPRINGS}

LOCATION: Latitude: $39^{\circ} 00^{\prime} 44 \mathrm{~N} \mathrm{~N}$; Longitude: $106^{\circ} 5^{\prime} 26^{\prime \prime}$ W.; T. 12 S., R. 85 W., Sec. 16, 6th P.M.; Pitkin County; Maroon. Bells 7 1/2-minute topographic quadrangle map.

GENERAL: This group of two unused springs is Tocated at an elevation of $11,200 \mathrm{ft}$ in the Maroon Bells-Snowmass Wilderness area. Access is from Aspen, up Castle Creek along the county road for 6.0 miles to Conundrum Creek, along the jeep trail up Conundrum Creek until it ends, and then al ong the hiking trail to the springs. The springs are approximately $15.5 \mathrm{miles}$ south of Aspen.

GEOLOGY AND HYDROLOGY: The upper spring Tapproximately $100 \mathrm{ft}$ south of the lower spring) has a discharge of approximately $10 \mathrm{gpm}$, with a temperature of $32^{\circ} \mathrm{C}$. The lower spring has an estimated discharge of $50 \mathrm{gpm}$ with a temperature of $38^{\circ} \mathrm{C}$. The calcium sulfate waters of the spring contain $1,910 \mathrm{mg} / 1$ of dissolved solids.

The springs issue from the Pennsylvanian Maroon Formation (Fig. 16). The origin and occurrence of this spring is very anomalous. The springs are near the top of the drainage divide between the Roaring Fork and Gunnison Rivers in a sedimentary sequence that dips to the northeast.
While no faults are mapped in the immediate vicinity, several normal faults are located approximately $0.25 \mathrm{mile}$ to the west. As shown on the geologic map (Fig. 16), the sedimentary formations of the area have been intruded by Tertiary granodiorite. The author bel leves that the waters enter the Maroon Formation on the outcrop area to the south of the divide. As they migrate downdip, they become heated.

GEOTHERMOMETER ANALYSES: Barrett and Pearl (1978) have shown that the moderate flow rate $(50 \mathrm{gpm})$ and the excellent agreement between the theoretical cristobalite-induced silica solubility and the silica content of the springs suggest the subsurface temperature is not much greater than the surface temperature of the hot springs. Therefore, the temperature at depth in this area is probably between $40^{\circ} \mathrm{C}$ and $50^{\circ} \mathrm{C}$ ( Table 3 ).

RESOURCE ASSESSMENT: If Barrett's and Pearl's (1978) theory of the origin of these waters is correct, and assuming the nearby by faulting plays some part in their occurrence, the areal extent of the reservoir could be as much as $0.45 \mathrm{sq} \mathrm{mi}$. A reservoir of this size with an average temperature of $45^{\circ} \mathrm{C}$ could contain $.0042 Q^{\prime} s$ of heat energy (Table 2). 


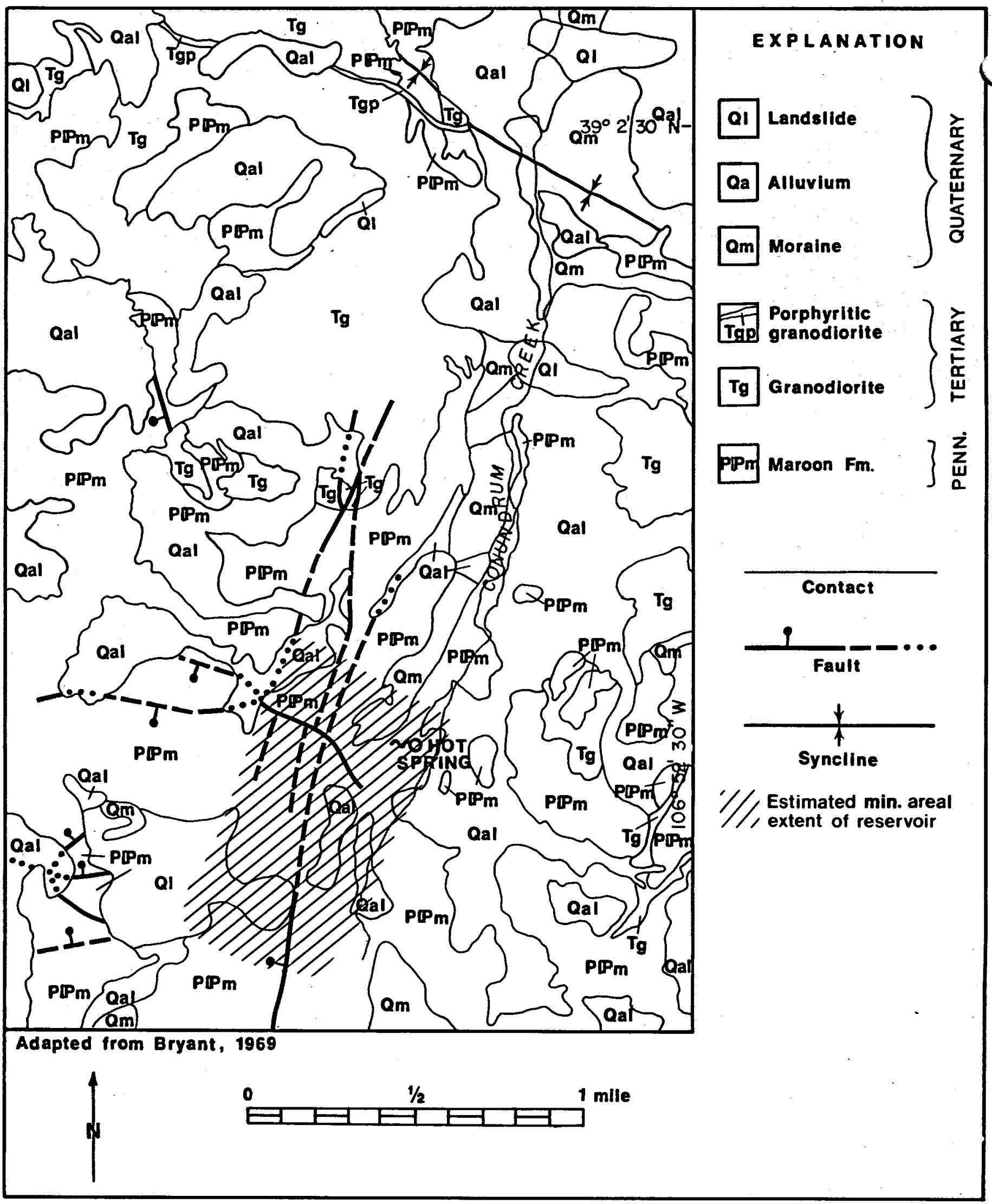

Figure 16.--Map showing estimated areal extent of the Conundrum Hot Springs reservoir and surrounding geologic conditions. 


\section{\#16 CEMENT CREEK WARM SPRING}

LOCATION: Latitude: $38^{\circ} 50^{\prime} 06^{\prime \prime N}$ : : Longitude: $106^{\circ} 49^{\prime} 34^{\prime \prime W . ; ~ T . ~} 14$ S.; R. 84 W.; Sec. $18 \mathrm{cac} ., 6$ th P.M.; Gunnison County; Cement Mtn. 7 1/2-minute topographic quadrangle map.

GENERAL: This small spring is located approximately 11.5 miles southeast of Crested Butte, Colorado, on Cement Creek. The spring is used for swimming and for the domestic water supply at the Cement Creek Ranch.

GEOLOGY AND HYDROLOGY: The spring emerges from colluvium at the base of the hill across the road from the ranch buildings. The ranch buildings are located on a large travertine mound approximately 15 to $20 \mathrm{ft}$ high and several hundred $\mathrm{ft}$ in diameter.

The spring has a discharge that varied throughout the year's time from 60 to $80 \mathrm{gpm}$ with a temperature of $25^{\circ} \mathrm{C}$. The waters are a calcium-carbonate type with total dissolved solids of approximately $390 \mathrm{mg} / 1$.

The geology of the Cement Creek Valley and surrounding area has been described in detail by McFarlan (1961). As shown on the accompanying geologic map (Fig. 17), the thermal waters come from und ifferentiated Precambrian granitic rocks.
While no fault zones are shown on the map, the waters come from fracture zones within these rocks.

GEOTHERMOMETER ANALYSES: Barrett and Pearl (1978) reported that the chalcedony-silica geothermometer model yielded an estimated subsurface temperature of $25^{\circ} \mathrm{C}$ to $30^{\circ} \mathrm{C}$. They noted that chalcedony mixing model analysis yields a subsurface temperature estimate of $27^{\circ} \mathrm{C}$ to $53^{\circ} \mathrm{C}$ with a cold-water fraction of 0 to 61 percent of the spring flow. The $\mathrm{Na}-\mathrm{K}$ geothermometer model gave a very high estimate $\left(225^{\circ} \mathrm{C}\right.$ to $\left.238^{\circ} \mathrm{C}\right)$ while the $\mathrm{Na}-\mathrm{K}-\mathrm{Ca}$ geothermometer model gave an estimated temperature of $45^{\circ} \mathrm{C}$ to $49^{\circ} \mathrm{C}$.

Conclusion: The good agreement between the mixing model and the silica and $\mathrm{Na}-\mathrm{K}-\mathrm{Ca}$ geothermometers suggests a subsurface temperature between $30^{\circ} \mathrm{C}$ and $60^{\circ} \mathrm{C}$ (Table 3 ).

RESOURCE ASSESSMENT: Since there is a possibility that these waters could be associated with the large fault approximately 0.75 miles to the west, two estimates of reservoir extent were made (Fig. 17). The more conservative estimate contained approximately $0.28 \mathrm{sq} \mathrm{mi}$ around the spring. The second showed the area to extend from the fault to just east of the spring, this area was estimated to contain $1.40 \mathrm{sq} \mathrm{mi}$. The amount of heat estimated to be contained within this system at an average temp. of $45^{\circ} \mathrm{C}$ ranges from $.0132 \mathrm{Q}^{\prime} \mathrm{s}$ to $.0658 \mathrm{Q}^{\prime} \mathrm{s}$ (Table 2). 


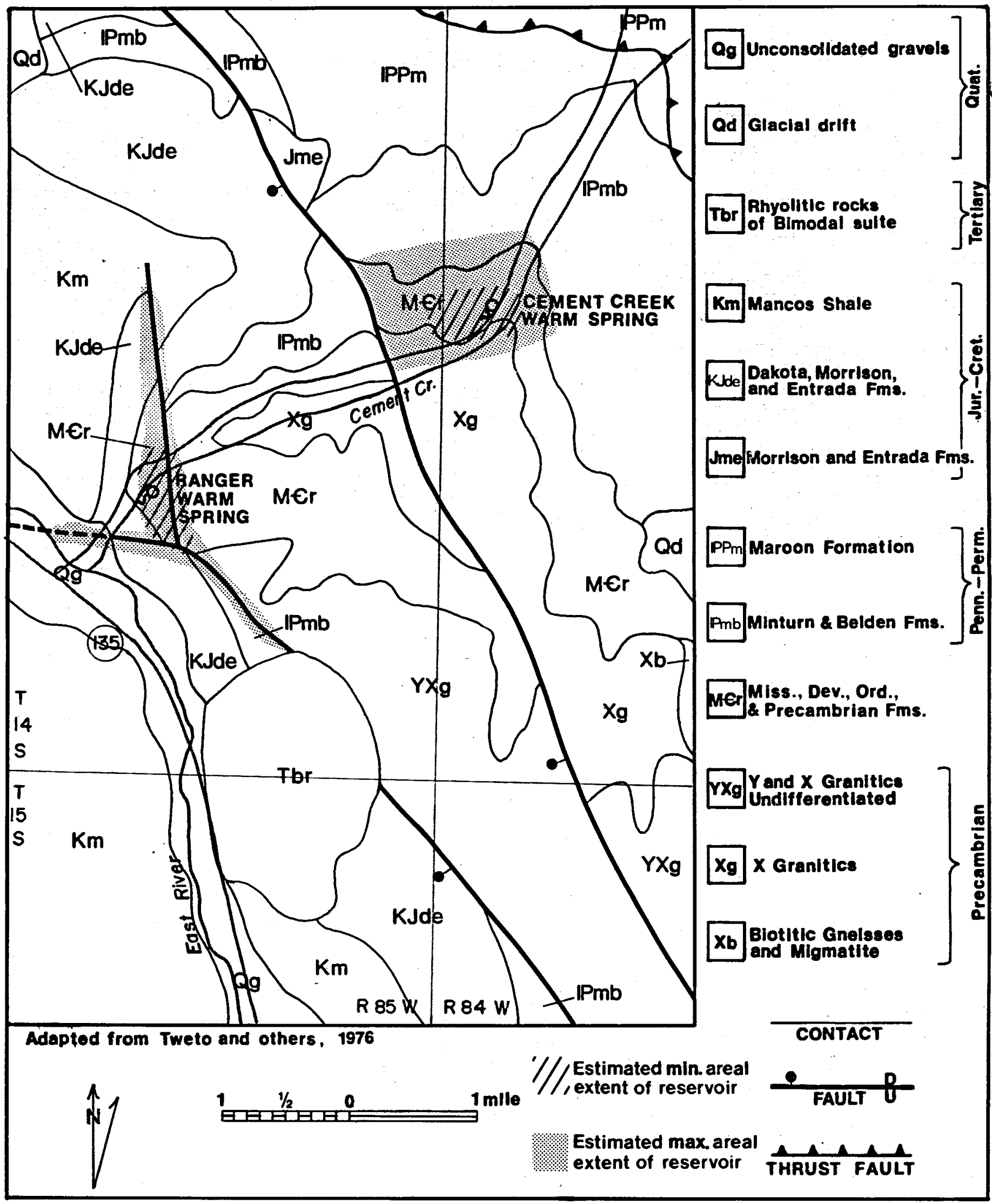

Figure 17.--Map of Cement Creek and Ranger Warm Springs showing estimated areal extent of the reservoir and surrounding geologic conditions. 


\section{\#17 RANGER WARM SPRING}

LOCATION: Latitude: $38^{\circ} 48^{\prime} 57^{\prime \prime N}$; Longitude: $106^{\circ} 52^{\prime 2} 28^{\prime \prime W}$; T. 14 S., R. 85 W., Sec. 22 dc., 6th P.M.; Gunnison County; Cement Mtn. 7 1/2-minute topographic quadrangle map.

GENERAL: The spring is on the south side of Cement Creek, 7 miles from Crested Butte. Waters from the spring are unused.

GEOLOGY AND HYDROLOGY: The temperature of the spring remained fairly constant throughout the year's time at 26 to $27^{\circ} \mathrm{C}$. The discharge varied from 132 to an estimated $250 \mathrm{gpm}$. The waters contain approximately $465 \mathrm{mg} / 1$ of dissolved sol ids and are a sodium-bicarbonate type.

As noted on Figure 17 the springs emerge from undifferentiated sedimentary rocks of Cambrian-Mississippian age. These formations are an alternating sequence of sandstones and limestones with some thin shale units. Due to the scale of the geologic map, it was not possible to show all the fault zones. McFarlan (1961) has projected an east-west fault passing very near or through this spring along the valley floor. Tweto and others (1976), show one major north-south trending fault in the vicinity. While the thermal waters may be moving along fault zones, for resource assessment it was assumed that the reservoir is a stratigraphic reservoir $150^{\prime}$ thick. No appraisal was made of which stratigraphic unit the waters may be coming from.

GEOTHERMOMETER ANALYSES: The chalcedony-silica geothermometer model is the most applicable to estimate the subsurface temperature (Barrett and
Pearl, 1978). This model yields an estimate of $28^{\circ} \mathrm{C}$ to $32^{\circ} \mathrm{C}$ (Table 3 ). The chalcedony mixing model yields an estimated reservoir temperature ranging from $29^{\circ} \mathrm{C}$ to $67^{\circ} \mathrm{C}$ with a cold-water fraction of 1 to 71 percent of the spring flow (Table 3). The $\mathrm{Na}-\mathrm{K}$ and $\mathrm{Na}-\mathrm{K}-\mathrm{Ca}$ geothermometer models yield estimated reservoir temperatures ranging from $56^{\circ} \mathrm{C}$ to $218^{\circ} \mathrm{C}$ (Table 3), depending upon the time of year the sample was taken. Since travertine deposits surrounds the spring and if calcium carbonate deposition still occurs, both the $\mathrm{Na}-\mathrm{K}$ and $\mathrm{Na}-\mathrm{K}-\mathrm{Ca}$ geothermometer estimates will be too high (Barrett and Pearl, 1978).

Conclusion: The good agreement between the mixing model and the silica and $\mathrm{Na}-\mathrm{K}-\mathrm{Ca}$ geothermometers suggests subsurface temperatures between $30^{\circ} \mathrm{C}$ and $60^{\circ} \mathrm{C}$ (Table 3 ).

RESOURCE ASSESSMENT: As shown on Fig. 17, the stratigraphic units in the vicinity of the springs are Precambrian-Mississippian undivided. With the exception of the Precambrian age rock, all the others are predominately carbonates, normally good aquifers.

Due to the occurrence of major faults in the area, two estimates were made of the areal extent of the reservoir (Fig. 17). The more conservative estimate contains $0.30^{\circ} \mathrm{sq} \mathrm{mi}$, and the other which was drawn to include more of the faulting, is estimated to contain approximately $0.88 \mathrm{sq} \mathrm{mi}$. The amount of energy estimated to be contained in this system at an average temperature of $45^{\circ} \mathrm{C}$ ranges. from .0021 Q's to .0062 $Q^{\prime}$ (Table 2). 


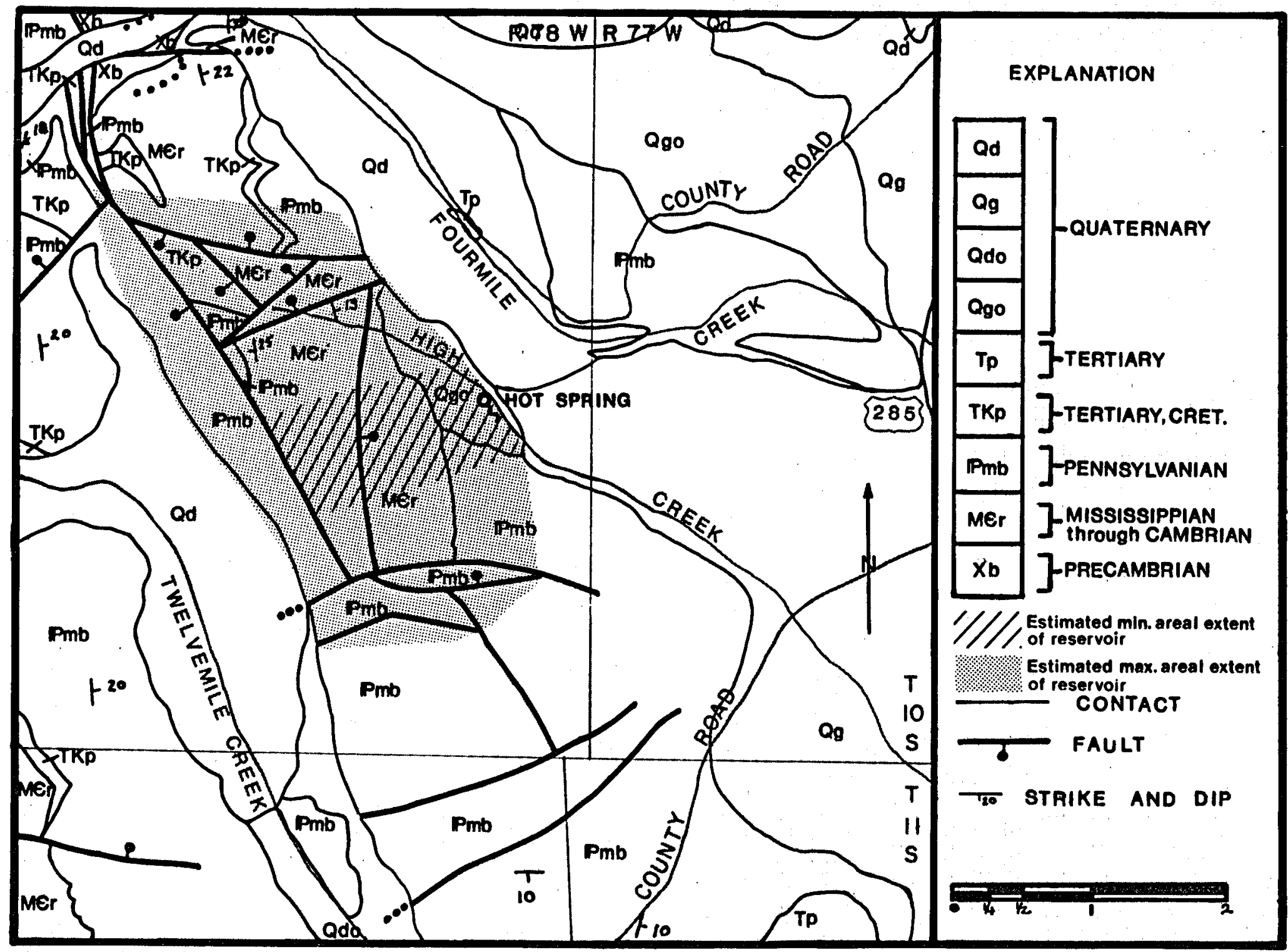

Adapted from Tweto and others, 1976

Figure 18.--Rhodes Warm Spring, geology of surrounding area and estimated areal extent of the geothermal reservoir. 


\section{\#18 RHODES WARM SPRING}

LOCATION: Latitude: $30^{\circ} 09^{\prime} 49^{\prime \prime} \mathrm{N} . ; \quad$ Longitude: $106^{\circ} 03^{1} 53^{\mathrm{WW}}$.; T. $10 \mathrm{~S}$., R. $78 \mathrm{H}$., Sec. $24 \mathrm{~cd}, 6$ th P.M.; Park County; Fairplay West 7 1/2-minute topographic quadrangle map.

GENERAL: This unused spring is reached by going south on U.S. 285 from Fairplay for approximately 4.0 miles, or 0.3 mile south of the bridge over Fourmile creek and then west on a dirt trail for approximately 3.75 miles.

GEOLOGY AND HYDROLOGY: The spring has a Eemperature of $24^{\circ} \mathrm{C}$ and a discharge of $200 \mathrm{gpm}$. The waters contain approximately $190 \mathrm{mg} / 1$ of dissolved solids and are a calcium bicarbonate type.

Rhodes Warm Spring is located on the west side of South Park, a large intermontain basin. Very little has been written on the geology of this part of South Park. DeVoto (1971) described in general the Cenozoic history of South Park. Knepper and Grose (1976) have described South Park as a complexiy faulted Laramide structural basin that was excavated in late Cenozoic time. Chronic (1964) has described the stratigraphy along the west side of the basin.

As shown on Figure 18, the area around the warm springs is cut by numerous fautts. While the waters are shown as issuing from Quaternary gravels and colluvial deposits overlying the. Pennsyivanian
Maroon Formation, it is believed that they are fault controlled. Recharge probably occurs along the Tenmile Range to the west. Reiter (1975) indicates that this area has a heat flow of 2.5 heat flow units.

GEOTHERMOMETER ANALYSES: While the estimated subsurface temperatures may be calculated by use of the various geothermometer models, these models should be used with caution when applied to Rhodes Warm Spring because many of the assumptions inherent in their use do not apply (Barrett and Pearl, 1978). The high flow rate (approximately 200 $\mathrm{gpm}$ ) and low surface temperature of this spring $\left(25^{\circ} \mathrm{C}\right)$ suggest that the subsurface temperature is not much greater than the surface temperature of the warm water. Therefore, the subsurface temperature in this area is probably between $25^{\circ} \mathrm{C}$ and $35^{\circ} \mathrm{C}$ (Table 3 ).

RESOURCE ASSESSMENT: Since Barrett and Pearl (1978) estimated that the occurrence of this spring to be fault controlled, two estimates of the reservoirs areal extent were made (Fig. 18). One estimate extends the reservoir from the springs to the west to the fault zone. This reservoir is estimated to contain .0432 Q's of heat energy. The other estimate of reservoir extent is much more optimistic. It contains 7.1 sq mi and encompassed practicaliy all of the faults in the immediate area. This reservoir is est imated to contain .2003 $Q^{\prime}$ 's of heat energy (Table 2 ). 


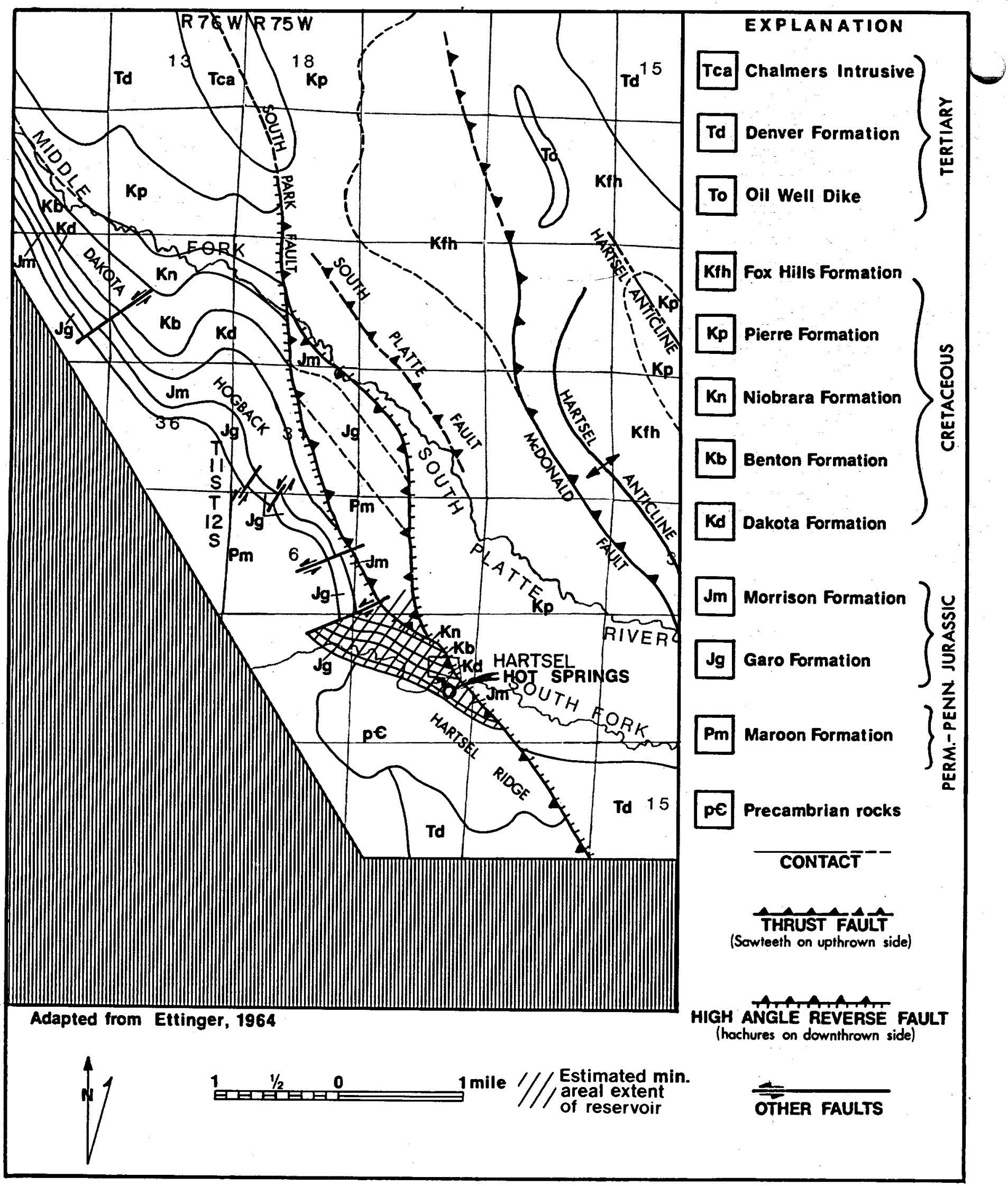

Figure 19.--Map showing estimated areal extent of the Hartsel Hot Springs geothermal reservoir and geology of surrounding area. 


\section{\#19 HARTSEL HOT SPRING}

LOCATION: Latitude: $\quad 39^{\circ} 01^{\prime} 05^{\prime \prime N}$; Longitude: $105^{\circ} 47^{\prime} 40^{\prime}$ W.; T. 12 S., R. 75 W. , Sec. 8 da, 6 th P.M.; Park County; Hartsel 7 1/2-minute topographic quadrangle map.

GENERAL: The Hartsel Hot Springs are located in South Park on U. S. Highway 24 just south of the town of Hartse1. Both springs are presently unused.

GEOLOGY AND HYDROLOGY: These springs have a combined discharge of $107 \mathrm{gpm}$. The western spring has a discharge of approximately $57 \mathrm{gpm}$ and the eastern spring a discharge of $50 \mathrm{gpm}$. Water of both springs are a sodium-chloride type. Throughout a year's time the temperature of the springs ranged from $45^{\circ} \mathrm{C}$ to $52^{\circ} \mathrm{C}$, with the total dissolved solids content varying from $2,140 \mathrm{mg} / 1$ to $2,330 \mathrm{mg} / 1$ (Barrett and Pearl, 1978).

These springs are located in the south-central part of South Park, a large intermontane basin bounded by the Mosquito Mountains on the west, the Continental Divide on the north, and the Front Range on the east. Several large north-south faults traverse the basin. One of these, the South Park Fault, is within 0.5 mile of the Hot Springs (Fig. 19). The springs emerge from the Morrison Formation, which overlies a large outcrop of Precambrian granitic rocks. Not shown on the geologic map (Fig. 19) are, to the south and east, the extensive outcrops of Tertiary volcanic rocks. The distribution, age, and mode of occurrence of these volcanic rocks have been discussed in detail by Epis and Chapin (1968).
The origin of these hot springs has not been determined, but they may be related to the South Park Fault and the volcanic rocks to the south and east. Reiter (1975) states that this area has a heat flow of 2.4 heat flow units.

GEOTHERMOMETER ANALYSES: Barrett and Pearl (1978), in describing geothermometer analys is of Hartsel Hot Spring, showed that the chalcedony-silica geothermometer model yields a subsurface temperature estimate of $55^{\circ} \mathrm{C}$ to $63^{\circ} \mathrm{C}$. Chalcedony mixing model analysis yields a subsurface estimate of $73^{\circ} \mathrm{C}$ to $87^{\circ} \mathrm{C}$ with a cold water fraction of 33 to 53 percent of the spring flow, and the $\mathrm{Na}-\mathrm{K}$ and $\mathrm{Na}-\mathrm{K}-\mathrm{Ca}$ geothermometers estimated subsurface temperatures of $163^{\circ} \mathrm{C}$ and $153^{\circ} \mathrm{C}$ respectively (Table 3).

Conclusion: The insignificant variation in flow, mineral content, surface temperature and geothermometer temperature estimates of these hot springs suggests that they are not materially affected by seasonal metereological conditions. Moreover, the fluctuation of the various geothermometer temperature estimates is well within the range of values that could result from normal analytical error. The geochemistry of these waters is such that no reliable subsurface temperature estimate is possible (Barrett and Pearl, 1978).

RESOURCE ASSESSMENT: The areal extent of the reservoir was drawn to include all the faulting in the area plus some of the Precambrian age rocks. The reservoir extent is estimated to be $1.00 \mathrm{sq} \mathrm{mi}$ and contain .0470 Q's of heat energy at an average temp. of $70^{\circ} \mathrm{C}$ (Table 2 ). 


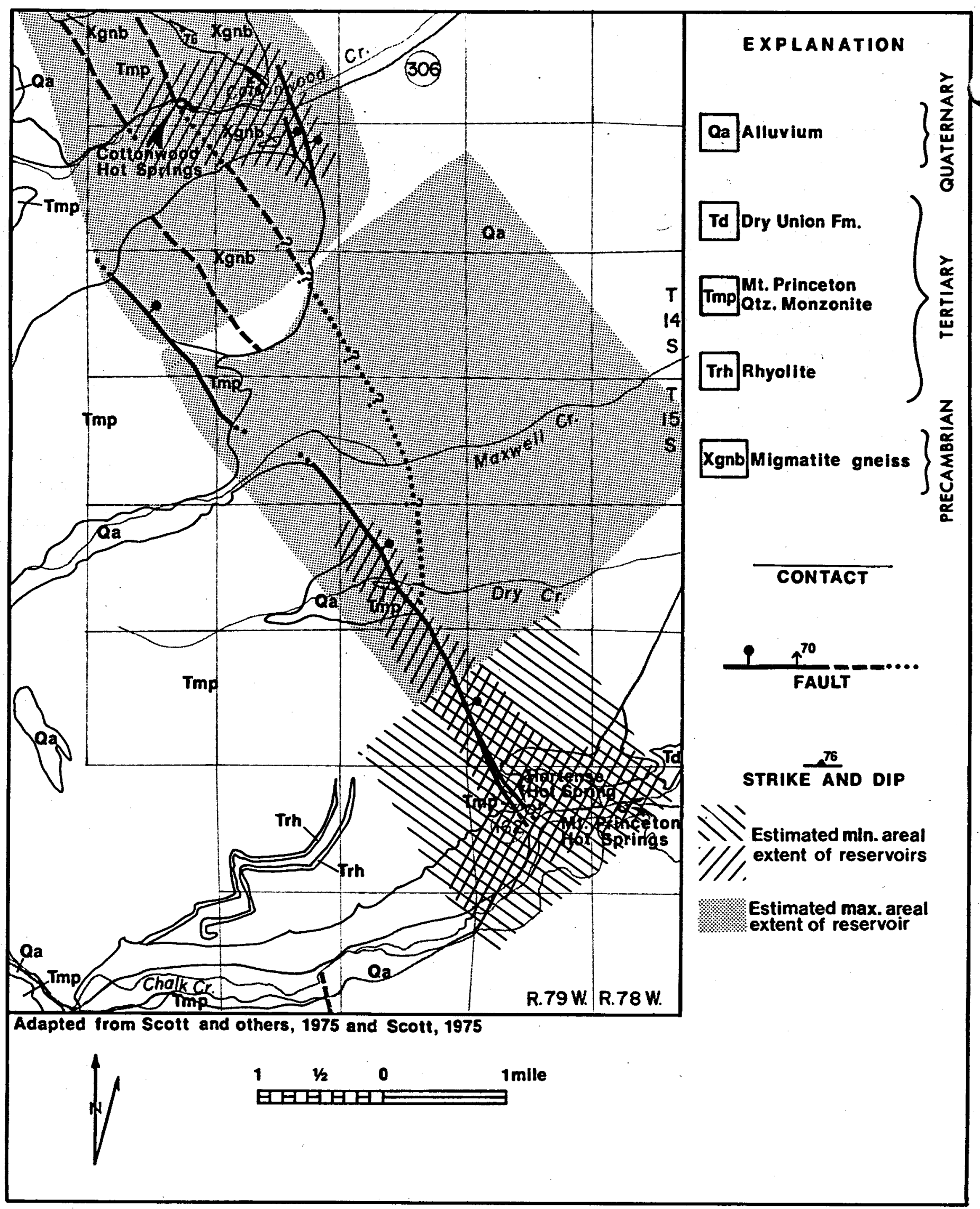

Figure 20.--Geologic map of region surrounding Cottonwood Creek and Chalk Creek Valleys and estimated areal extent of the geothermal reservoirs. 


\section{\#20 COTTONWOOD CREEK}

\section{(COTTONWOOD AND JUMP-STEAD HOT SPRINGS)}

LOCATION: Latitude: $38^{\circ} 48^{\prime} 48^{\prime \prime}$.: Longitude: $106^{\circ} 13^{\top} 21$ "W.; T. 14 S., R. 79 W., Sec. 21 dca and ddb, 6th P.M.; Chaffee County; Buena Vista 15-minute topographic quadranglè map.

GENERAL: The Cottonwood Hot Springs are located approximately 5.6 miles west of Buena Vista along Colorado Highway 306 on the banks of Cottonwood Creek on the north side of Mt. Princeton. Modifications of the topography by the highway and the users of the springs make it impossible to accurately determine the number of springs in this group. The Jump-Steady resort, 0.5 mile east of the springs, uses the waters from another spring a short distance east of the Cottonwood Hot Springs for space heating and domestic purposes.

Mr. and Mrs. Merrifield, who i ive approximately 0.75 mile south of Cottonwood Creek, have a 115-ft-deep-hot-water well. The waters from this well are used in their greenhouse and swimming pool, and for space heating.

GEOLOGY AND HYDROLOGY: The temperatures of these springs and one well range from a low of $46^{\circ} \mathrm{C}$ to a high of $58^{\circ} \mathrm{C}$. The waters are a sodium-bicarbonate type and contain between 300 and $370 \mathrm{mg} / 1$ of dissolved solids.

Although the waters issue from alluvium and coluvium covering the Mount Princeton quartz monzonite, they are related to the faulting and fracturing of that rock body. The accompanying geologic map (Fig. 20) shows that the Cottonwood Hot Springs are located on a major northwest-trending fault bordering the east side of Mount Princeton. In addition to this fault, other factors may control the occurrence of these springs because the rock types change from Precambrian migmatitic gneiss on the south side of Cottonwood Creek to the Mt. Princeton Quartz Monzonite on the north side of Cottonwood Creek. Scott (1975) did not map any faults in this area; however, some workers have postulated that a fault does follow cottonwood Creek (Robert Kirkham, 1977, oral communication).

One possible recharge area for these springs is the Arkansas River to the east, where the waters enter the thick valley-fill sequence (Zohdy and others, 1971), move to the west, and then up the fault zones. The other possible source is the high country along the Continental Divide just to the west where the waters enter and migrate downward along fault zones, and then up the faults to the Cottonwood Hot Springs.

Romero and Fawcett (1978), in attempting to relate the geothermal resources of the upper Arkansas and San Luis Valleys to the ground-water resources of those areas, had detafled electrical

hysical surveys ran of the area from just south Aineral Hot Springs in the San Luis Valley to a point approximately 4 miles north of Cottonwood Hot Springs in the upper Arkansas Valley. These surveys determined that a series of resistivity lows and highs exist from Mineral Hot Springs to Cottonwood Hot Springs: The lows clearly define the shape and extent of the Rio Grande Rift.

GEOTHERMOMETER ANALYSES: Barrett and Pear1 (1978) pointed out that because these springs lie within the boundaries of the Mt. Princeton quartz monzonite batholith (Scott, 1975), quartz, not cristobalite, is probably the most abundant solid silica phase. The quartz silica geothermometer estimate of subsurface temperature is $105^{\circ} \mathrm{C}$ to $182^{\circ} \mathrm{C}$ (Table 3 ). Mixing model analysis of Cottonwood and Jump-Steady Hot Springs yields a subsurface temperature estimate of $174^{\circ} \mathrm{C}$ to $182^{\circ} \mathrm{C}$ with a cold water fraction of 70 to 74 percent of the spring flow.

The $\mathrm{Na}-\mathrm{K}$ and $\mathrm{Na}-\mathrm{K}-\mathrm{Ca}$ geothermometers est imates of subsurface temperature are $131^{\circ} \mathrm{C}$ to $135^{\circ} \mathrm{C}$ and $79^{\circ} \mathrm{C}$ to $85^{\circ} \mathrm{C}$ respectively. The $\mathrm{Na}-\mathrm{K}$ geothermometer estimates appear reasonable for both springs. They are substantiated by the silica geothermometer and mixing model results, but the Na-K-Ca geothermometer estimates are too iow. This may be caused by temperature-dependent equilibration between the thermal water and the relatively potassium-deficient quartz monzonite.

Conclusion: The most realistic geothermometer estimates of subsurface temperature range from $105^{\circ} \mathrm{C}$ to $182^{\circ} \mathrm{C}$ (Table 3 ).

RESOURCE ASSESSMENT: To fully appraise the resource potential of this area, two estimates of the faulted reservoirs areal extent were made. One est imate showed the maximum possible extent of the reservoir. The boundaries of this area were drawn to include an area that would encompass most of the faulting found along the mountain front plus some of the faulted area to the east. This area was estimated to contain approximateiy $4.14 \mathrm{sq} \mathrm{mi}$ and contain 1.1672 Q's of heat energy.

The other area, less extensive in size, includes only the area around the spring plus the immediate mountain front. This area is approximately $1.38 \mathrm{sq} \mathrm{mi}$ in extent and is estimated to contain . $3894 \mathrm{Q}^{\prime}$ s of energy at a temp. of $170^{\circ} \mathrm{C}$. (Table 2).

In the vicinity of Cottonwood Hot Springs, Romero and Fawcett (1978) determined that a resistivity low exists east of the mountain front and extends from Cottonwood Creek south almost all the way to Chalk Creek. This low-encompasses an area of approximately $6 \mathrm{sq} \mathrm{mi}$. Using the following criteria, Romero and Fawcett (1978) calculated that the system contained $15.48 \mathrm{Q}$ 's of energy: depth to top of reservolr, $2,500 \mathrm{ft}$; depth to base of 
reservoir, 1.86 miles; areal extent of the reservoir, $8.5 \mathrm{sq} \mathrm{mi}$; average maximum temperature, $129^{\circ} \mathrm{C}$. Because the parameters they used were different, the amount of heat calculated is considerably higher than that calculated by author (1.1682 Q's). 


\section{\#21 CHALK CREEK AREA}

The following thermal springs and wells are located in the Chalk Creek Valley on the south flank of Mount Princeton: Mount Princeton Hot Springs, Hortense Hot Spring and Well, Woolmington Hot Water Well, Wright Hot Water Wells, and Young Life Hot Water Well.

These springs are located on the south side of Mount Princeton southwest of Buena Vista in the Chalk Creek Valley within 1 or 2 miles of each other along Colorado Rt. 162 approximately 4.5 miles west of U.S. Highway 285 (Fig. 20).

GEOLOGY: The geological conditions surrounding the thermal springs and wells in the Chalk Creek Valley are nearly identical. The springs lie on the south side of Mount Princetion on the west side of the Upper Arkansas Valley graben. Southwest of Buena $V$ ista the graben is asymetrical with the east side downdropped more than the west side. Geophysical work by Zohdy and others (1971) has revealed as much as $4,600 \mathrm{ft}$ of valley-fill sediments near Buena Vista. All the thermal waters are associated with faults and fractures within the Mount Princeton Quartz Monzonite batholith. The accompanying geological map (Fig. 20) does not show the numerous faults and fractures in the Chalk Cliffs. The whole Upper Arkansas Valley is cut by numerous faults; however, Scott and others (1975) show only one major northwest trending fault in the southern Mount Princeton area. This fault lies along the east face of Mount Princeton and terminates at the Hortense Hot Spring. Other workers have postulated that a major fault trends northeast along the Chalk Creek Valley (Robert Kirkham, 1977, oral communication).

The possible recharge areas are either the Arkansas River to the east or the high country to the west.

As explained earlier (see Cottonwood Hot Springs), Romero and Fawcett (1978) did a geophysical appraisal of the geothermal conditions in the upper Arkansas Valley. Their work showed that no clear cut resistivity low exists in the immediate vicinity of the Mount Princeton Hot Springs. They did show the presence of a reisistivity low northeast of the springs.

\section{\#21 MOUNT PRINCETON HOT SPRING}

LOCATION: Latitude: $38^{\circ} 43^{\prime} 58^{\prime \prime} N$.; Longitude: $106^{\circ} 09^{\circ} 40^{\prime}$ W.; T. 15 S., R. 78 W., Sec. 19 bCa, 6th P.M.; Chaffee County; Poncha Springs 15-minute topographic quadrangle.

GENERAL: The Mount Princeton Hot Springs are the Targest group of springs in the Chalk Creek Valley. The springs are located in and along the north bank of Chalk Creek extending from immediately west of the big wooden building by the swimming pool to just east of the swimming pool. Some of the waters are piped uphill and used to heat the swimming pool and cabins north of Colorado 162.

HYDROLOGY: All of the springs in this group have temperatures ranging between $44^{\circ} \mathrm{C}$ and $56^{\circ} \mathrm{C}$. The waters contain approximately $250 \mathrm{mg} / 1$ of dissolved solids and are a mixed sodium sulfate-bicarbonate type. The combined flow of all the springs, as measured by a Parshall Flume, was $175 \mathrm{gpm}$. This value may be low due to any pumping of thermal waters that might have been occurring.

\section{\#21 WRIGHT HOT WATER WELLS (EAST AND WEST)}

LOCATION: East We11: Latitude: $38^{\circ} 44^{\prime} 00^{\prime \prime}$. ; Longitude: $106^{\circ} 10^{\prime} 00^{\prime \prime W}$; T. 15 S., R. 79 W.; Sec. 24 ca, 6th P.M.; Chaffee County; Poncha Springs 15-minute topographic quadrangle map.

West We11: Latitude: $38^{\circ} 43^{\prime} 58^{\prime N_{\text {. }} ;}$ Longitude: $106^{\circ} 10^{\top} 25$ "W.; T. 15 S., R. 79 W.; Sec. 24 ac, 6th P.M.; Chaffee County; Poncha Springs 15-minute topographic quadrangle map.

GENERAL: Approximately one mile west of the Mount Princeton Hot Springs are two thermal wells owned by William Wright. Waters from these two wells are used to heat greenhouses. In addition, waters from the east well are used for heating two houses immediately to the south. The east well is located in the greenhouse situated just south of Highway 162. The west well is located in the greenhouse located approximately $0.5 \mathrm{mile}$ west and $0.25 \mathrm{mile}$ north of the east greenhouse.

HYDROLOGY: The east well is $40 \mathrm{ft}$ deep, and the waters have a temperature of $67^{\circ} \mathrm{C}$ with $234 \mathrm{mg} / \mathrm{l}$ of dissolved solids. The waters are a mixed sodium sulfate-bicarbonate type. Waters from the west well have a temperature of $72^{\circ} \mathrm{C}$ with $313 \mathrm{mg} / 1$ of dissolved solids. Unlike the waters from the east well, these waters are a sodium-bicarbonate type. 


\section{\#21 HORTENSE HOT SPRING AND WEL, AND YOUNG LIFE HOT WATER WEI}

LOCATION: Hortense Hot Spring: Latitude: $38^{\circ} 43^{\prime} 59^{\prime \prime} N_{\text {. ; }}$ Longitude: $106^{\circ} 10^{\prime} 26^{\prime \prime}$. ; T. 15 S.; R. 79 W.; Sec. 24 bd, 6th P.M.; Chaffee County; Poncha Springs 15-minute topographic quadrangle map.

Hortense Hot Water Well: Latitude: $38^{\circ} 43^{\prime} 58^{\prime \prime N}$.; Congitude: $106^{\circ} 10^{\prime} 27^{\prime \prime W}$; T. 15 S., R. 79 W., Sec. 24 bd; Chaffee County; Poncha Springs 15-minute topographic quadrangle map.

Young Life Hot Water Well: Latitude: $38^{\circ} 43^{\prime} 57^{\prime \prime N . ; ~}$ Longitude: $106^{\circ} 10^{\prime} 27^{\prime \prime} W_{0}$; T. 15 S., R. 79 W.; Sec. 4b; Chaffee County; Poncha Springs 15-minute topographic quadrangle map.

GENERAL: Just to the north and to the west of the West Wright Hot Water Well are two wells and one spring. The Hortense Hot Spring is located approximately from this spring, which are the hottest in the State, are piped to the Young Life Camps and used for recreational purposes. The Hortense Hot Water Well is located to the west of the Wright Greenhouse. Waters from this well, approximately $180 \mathrm{ft}$. deep, are also used in the Young Life Camp for domestic purposes. The Young Life Hot Water Well is located approximately 200 yd to the west of the Hortense Hot Water Well. Waters from this, well are also piped to the Young Life Camp.

HYDROLOGY: Both the Hortense Hot Water Well and Spring have temperatures of $82^{\circ} \mathrm{C}$. The discharge of the spring is $18 \mathrm{gpm}$. The total dissolved solids content of the spring is approximately $340 \mathrm{mg} / 1$, and the well was $318 \mathrm{mg} / 1$. The Young Life Well has a dissolved mineral content of $259 \mathrm{mg} / 1$. Waters from all three are a mixed sodium sulfate-bicarbonate type.

\section{\#21 WOOLMINGTON HOT WATER WELL}

LOCATION: Latitude: $38^{\circ} 43^{\prime} 24^{\prime \prime N}$; Longitude: $106^{\circ} 10^{\top} 38^{\prime \prime W . ; ~ T . ~} 15$ S., R. 79 W.; Sec. 24 db, 6th P.M.; Chaffee County; Poncha Springs 15-minute topographic quadrangle map.

GENERAL: This well, which is the westernmost thermal water found in the Chalk Creek Valley, is located approximately 0.75 mile west of the Young Life Camp and 100 yd south of the highway. At the

GEOTHERMOMETER ANAL YSES OF CHALK CREEK AREA: While analysis of silica solubility and temperature relationships suggest that temperature-dependent equilibration between the thermal water and chalcedony controls the silica content of the hot springs and wells chalcedony is not likely to be abundant because this thermal area is located well within the boundaries of the Mount Princeton Batholith (Scott and others, 1975 and Barrett and Pearl, 1978). The most abundant solid silica phase in this area is probably quartz suggesting that the quartz-silica geothermometer and the quartz mixing models are applicable.

The quartz-silica geothermometer estimate of subsurface temperature is $105^{\circ} \mathrm{C}$ to $127^{\circ} \mathrm{C}$ for Mount Princeton Hot Springs and $116^{\circ} \mathrm{C}$ to $129^{\circ} \mathrm{C}$ for Hortense Hot Springs (Barrett and Pearl, 1978). Sharp (1970) noted that boulders near. Hortense Hot Spring are coated with a mixture of calcite, opal and phillipsite. If deposition of silica occurs at depth, then the silica geothermometer and mixing model estimates are too low.

Mixing model analysis yields a subsurface temperature estimate of $186^{\circ} \mathrm{C}$ to $236^{\circ} \mathrm{C}$ with a cold-water fraction of 77 to 81 percent for Mount time Barrett and Pearl (1978) visited the well (Fall, 1975), the waters were unused.

HYDROLOGY: The temperature of the waters is $39^{\circ} \mathrm{C}$ and the total dissolved solids content is $143 \mathrm{mg} / 1$. The waters are a sodium-bicarbonate type. The waters come from the alluvial and colluvial deposits north of Chalk Creek.

Princeton Hot Springs and a subsurface temperature estimate of $156^{\circ} \mathrm{C}$ to $186^{\circ} \mathrm{C}$ with a cold-water fraction of 54 to 61 percent for Hortense Hot Spring (Table 3). These estimates may be too high, however, because steam fumeroles occur near Hortense Hot Spring (Jay Dick, 1976, personal communication).

Since steam vents are associated with these waters, Mixing Model II may be applied. This model yields a subsurface temperature estimate of $131^{\circ} \mathrm{C}$ to $150^{\circ} \mathrm{C}$ with a hot water fraction of $43 \%$ to $52 \%$ for Mount Princeton Hot Springs and a subsurface temperature estimate of $120^{\circ} \mathrm{C}$ to $131^{\circ} \mathrm{C}$ with a hot-water fraction of 9 to 12 percent for Hortense Hot Spring. These estimates may be too low, with the actual subsurface temperature probably lying between the Mixing Model I and Mixing Model II estimates.

The enthalpy-chloride geothermometer can be applied to this thermal area because the surface temperature of Hortense Hot Spring $\left(83^{\circ} \mathrm{C}\right)$ is near the boiling point for the elevation. This geothermometer yields a subsurface temperaturo estimate of $160^{\circ} \mathrm{C}$. A plot of the field d\& (temperature and silica content) of the hot springs 
superimposed on the quartz silica geothermometer felds $153^{\circ} \mathrm{C}$.

The Na-K and $\mathrm{Na}-\mathrm{K}-\mathrm{Ca}$ geothermometers yield subsurface temperature estimates of $148^{\circ} \mathrm{C}$ to $151^{\circ} \mathrm{C}$ and $51^{\circ} \mathrm{C}$ to $59^{\circ} \mathrm{C}$, respectively, for Mount Princeton Hot Springs and $141^{\circ} \mathrm{C}$ to $146^{\circ} \mathrm{C}$ and $93^{\circ} \mathrm{C}$ to $97{ }^{\circ} \mathrm{C}$. respectively, for Hortense Hot Spring (Table 3 ). The $\mathrm{Na}-\mathrm{K}$ geothermometer est imates for both springs groups appear reasonable, and they are substantiated by the silica geothermometer and mixing model results. On the other hand, the $\mathrm{Na}-\mathrm{K}-\mathrm{Ca}$ geothermometer estimates seem to be too low.

The low Na-K-Ca geothermometer estimates may be caused by temperature-dependent equilibration between the ascending thermal water and the relatively potassium-deficient quartz monzonite. In addition, the hot spring waters are supersaturated with respect to albite, calcite, 1 aumontite, and quartz (Limbach, 1975). Supersaturation of the thermal waters with respect to calcite would cause the $\mathrm{Na}-\mathrm{K}-\mathrm{Ca}$ geothermometer estimates to be too low.

Conclusion: The most realistic geothermometer estimates of subsurface temperature range from $150^{\circ} \mathrm{C}$ to $200^{\circ} \mathrm{C}$ (Table 3 ). These results are in close agreement with the formation temperature of laumontite (hydrated leonhardite) $145^{\circ} \mathrm{C}$ to $220^{\circ} \mathrm{C}$, reported by Combs (Sharp, 1970).
RESOURCE ASSESSMENT: Based on geological and geophysical surveys, three estimates of this systems areal extent were made. Romero and Fawcett (1978) have shown that a geophysical anomaly exists along the front of Mt. Princeton. Therefore, the boundaries of one of the estimates were drawn to include this large area. This area was estimated to cover $10.0 \mathrm{sq} \mathrm{mi}$ and contain $2.6314 \mathrm{Q}$ 's of energy at an average temperature of $160^{\circ} \mathrm{C}$ (Table $2)$. The boundaries of the intermediate size area (4.0 $\mathrm{sq} \mathrm{mi}$ ) were drawn on the assumption that the reservoir was restricted to an area immediately around the spring. The boundaries of the most conservative case were drawn to cover an area following closely the major NW-SE trending fault along the mountain front (Fig. 20). This area was estimated to be $3.14 \mathrm{sq} \mathrm{mi}$ in extent and contain $1.0623 \mathrm{Q}^{\prime} \mathrm{s}$ of energy at a temperature of $200^{\circ} \mathrm{C}$ (Table 2).

Romero and Fawcett (1978) in attempting to evaluate the heat content of this system calculated that it would contain as much as $53.17 \mathrm{Q}^{\prime} \mathrm{s}$ an estimate much greater than that presented above. The reason for the greater values is the reservoir parameters used: reservoir thickness, 7,321 ft; areal extent of the reservoir, $27 \mathrm{sq} \mathrm{mi}$; and average maximum temperature of $139^{\circ} \mathrm{C}$. The total amount of heat contained in the cottonwood-Mount Princeton system was estimated by Romero and Fawcett (1978) to be $68.6 \mathrm{Q}$ 's, while the author estimated that the system could contain a maximum of $3.81 Q^{\prime} s$. 


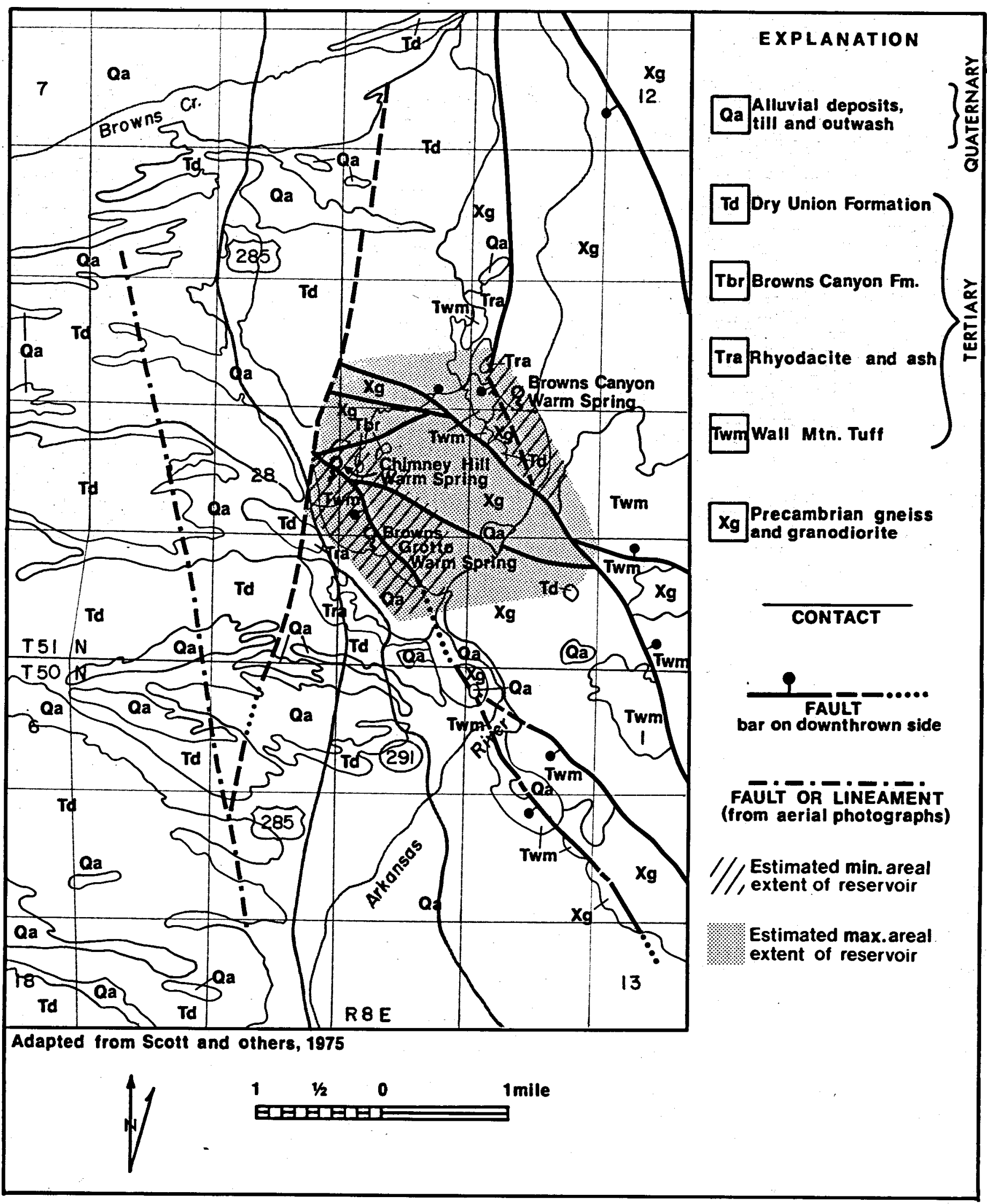

Figure 21.--Map showing estimated areal extent of the Browns Canyon geothermal reservoir and geology of surrounding area. 


\section{\#22 BROWNS CANYON THERMAL AREA}

Located in Browns Canyon, approximately 12 miles north and west of Salida, Colorado, are two unused springs and one unused well.

GEOLOGY OF BROWN'S CANYON: As shown on Figure 21, the springs and wells in Brown's Canyon are situated in a geologically complex region. Brown's Canyon is located on the east side of the Upper Arkansas Valley, a structural extension of the Rio Grande Rift zone. The bedrock of the area consists of Precambrian granitic and metamorphic rocks that make up the Arkansas Hills, on the east side of valley. In fault contact with these rocks is a middle Tertiary age complex assemblage of lava flows, ash beds, sandstones and shales of the Dry Union Formation, and alluvial deposits.

All the thermal waters in the region appear to be fault controlled, especially Brown's Grotto Warm Spring and Chimney Hill Warm Water Well. Reiter (1975) has shown that this area has a heat flow in excess of 2.5 heat flow units. The thermal waters probably represent deep circulation of ground water through fault zones in an area of high heat flow.

\section{\#22 BROWNS CANYON WARM SPRING}

LOCATION: Latitude: $38^{\circ} 39^{\prime} 13^{\prime \prime} \mathrm{N}_{\text {; }}$ : Longitude: $106^{\circ} 03^{\prime} 11$ W.; T. 51 N., R. 8 E., Sec. $23 \mathrm{cdb}$, N.M.P.M.; Chaffee County; Poncha Springs 15 minute topographic quadrangle map.

GENERAL: This unused spring may be located by going northwest from Saljda on State Highway 291 to U.S. 285. One half mile north of this intersection turn east on county road 194 and proceed northeast for approximately 2.4 miles to an old stone cabin. The spring is in an open area approximately $550 \mathrm{ft}$ north of the cabin.

HYDROLOGY: The spring has a discharge estimated at $1 \mathrm{gpm}$ with a temperature of $25^{\circ} \mathrm{C}$. The waters of the spring were not sampled for determination of dissolved mineral matter. Field measurement of specific conductance is 7,877 micromhos, and the $\mathrm{pH}$ is 8.0 .

\section{\#22 BROWNS GROTTO WARM SPRING}

LOCATION: Latitude: $38^{\circ} 38^{\prime} 13^{\prime \prime} \mathrm{N}$; Longitude: $106^{\circ} 04^{\prime} 26^{\prime \prime} W_{. ;}$T. 51 N., R. 8 E., Sec. 27 ccd, N.M.P.M.; Chaffee County; Poncha Springs 15 minute topographic quadrangle map.

GENERAL: This unused spring may be reached by turning off U.S. 285 on Chaffee County 194. After going 0.2 mile turn south and drive approximately
0.5 mile to the spring. The spring is on the east side of the small gulch.

HYDROLOGY: When sampled, this spring had an estimated discharge of $5 \mathrm{gpm}$ with a temperature of $23^{\circ} \mathrm{C}$. The waters contain $494 \mathrm{mg} / 1$ of dissolved mineral matter and are a mixed sodium sulfate-bicarbonate type.

\section{\#22 CHIMNEY HILL WARM WATER WELL}

LOCATION: Latitude: $38^{\circ} 38^{\prime} 40^{\prime \prime N}$.; Longitude: 1060441 "W.; T. 51 N., R. 9 E., Sec. 28 add, N.M.P.M.; Chaffee County; Poncha Springs 15-minute topographic map.

GENERAL: This well was located by J.D. Dick (1976) in 1975. This well is approximately $0.25 \mathrm{mile}$ north from the junction of U.S. 285 and Chaffee County 194. The depth of the well is unknown, and the waters are unused. Dick believes that the well

GEOTHERMOMETER - ANALYSES OF BROWN'S CANYON: Cristobalite appears to be controlling the silica content of Brown's Grotto Warm Springs (Barrett and (1, 1978). This geothermometer yields an simated temperature of $49^{\circ} \mathrm{C}$ (Table 3 ). However, may be used for drainage purposes at the abandoned Chimney Hill Mine. The well is capped but may be sampled by opening a valve on top of the casing.

HYDROLOGY: According to Dick (1976), the waters have a temperature of $27^{\circ} \mathrm{C}$. The discharge of the well was not measured. Dick (1976) determined that the waters contain $170 \mathrm{mg} / 1$ of sodium, $2.7 \mathrm{mg} / 1$ of potassium, $7 \mathrm{mg} / 1$ of calcium and $47 \mathrm{mg} / 1$ of silica.

this estimate may be too high because the theoretical cristobal ite-induced silica content ( 24 $\mathrm{mg} / 1)$ at the springs surface temperature $\left(22^{\circ} \mathrm{C}\right)$ is well below the silica content of the warm spring $(47 \mathrm{mg} / 1$ ). 
The cristobalite mixing model analysis yields a subsurface temperature estimate of $129^{\circ} \mathrm{C}$ with a cold water fraction of 87 percent for Brown's Grotto Warm Spring and an estimated temperature of $95^{\circ} \mathrm{C}$. with a cold-water fraction of 86 percent for the spring in fluorspar mine.

These estimates should be treated skeptically because the flow rate and silica contents of these springs are well below the minimum conditions specified for reliable mixing model results and, in addition, associated minerals complicate the mixing model analysis (Barrett and Pearl, 1978).

Chimney Hill Warm Water Well has a calculated reservoir temperature of $287^{\circ} \mathrm{C}$ with a cold water fraction of 95 percent (Dick, 1976).

The $\mathrm{Na}-\mathrm{K}$ and $\mathrm{Na}-\mathrm{K}-\mathrm{Ca}$ geothermometers yield subsurface temperature est imates of $123^{\circ} \mathrm{C}$ and $89^{\circ} \mathrm{C}$, respectively, for Brown's Grotto Warm Spring (Table 3 ), and $142^{\circ} \mathrm{C}$ and $131^{\circ} \mathrm{C}$ for the spring within the fluorspar mine. It should be noted that the $\mathrm{Na}-\mathrm{K}$ geothermometer estimates for both of these springs are too high since because the conditions of the model are violated (Barrett and Pearl, 1978). Dick (1976) calculated the Chimney Hill Warm Water Well subsurface temperature with this model to be $85^{\circ} \mathrm{C}$.

Conclusion: Geothermometer models should be used with caution when applied to Brown's Grotto Warm
Spring since most of the assumptions inherent in their use are violated.

Opal deposits at depth within the nearby fluorspar mine (Van A1stine and Cox, 1969) suggests temperatures at depth below, $100^{\circ} \mathrm{C}$. However, the extensive fluorspar deposits indicate subsurface temperatures between $119^{\circ} \mathrm{C}$ and $168^{\circ} \mathrm{C}$. At any rate, these considerations probably pertain to historical rather than present-day subsurface conditions. The best estimated temperature possible for this area ranges from $50^{\circ} \mathrm{C}$ to $100^{\circ} \mathrm{C}$ (Table 3 ).

RESOURCE ASSESSMENT OF BROWN'S CANYON: As shown on Figure 21, two of the three springs are associated with faults. Barrett and Pearl (1978) stated that they believe all three springs are fault controlled; therefore, the boundaries of this area were drawn to include most of the faulting in the area. As drawn, the area encompasses approximately $3.23 \mathrm{sq} \mathrm{mi}$ and contains approximately $.4856 \mathrm{Q} ! \mathrm{s}$ of energy at a maximum average temperature of $100^{\circ} \mathrm{C}$ (Table 2). If these springs are part of one large system, the reservoir may be too deep to be reached economically; therefore, estimates were made based on the assumption that each area would be developed separately. This analysis was based on the assumption that the individual reservoirs had an areal extent of $0.50 \mathrm{sq} \mathrm{mi}$ each and contained .2256 $Q$ 's of thermal energy at a maximum average temperature of $100^{\circ} \mathrm{C}$. 


\section{\#23 PONCHA HOT SPRINGS}

Located several hundred ft above the Arkansas River at the southern end of the Upper Arkansas River Valley is a large group of hot springs known as Poncha Hot Springs.

LOCATION: Five springs were located by Barrett \& Pearl (1978) during the course of their investigation at or near: Latitude: $38^{\circ} 29^{\prime} 49^{\prime \prime} \mathrm{N}$.; Longitude: $106^{\circ} 04^{\prime} 37^{\prime \prime}$ W.; T. 49 N., R. 8 E., Sec. 15 cb, N.M.P.M.; Chaffee County; Bonanza 15-minute topographic quadrangle map.

GENERAL: This large group of springs is located approximately one mile south of the town of Poncha Springs and just east of U.S. Highway 285. Access is via a dirt road from U.S. $285,1,000 \mathrm{ft}$ south of the bridge crossing the South Arkansas River.

The springs are contained in two distinct groups. The south group, Springs A \& B, just uphill from a group of buildings, is the main spring area. Another group of three unused springs lies over the ridge line and down in a small valley north of the main spring area. The main spring area is characterized by a large travertine apron extending over the entire hillside. At one time up to 40 springs issued on this hillside, but at the present time no thermal waters flow to the surface because of collection by buried pipelines. Most of the waters are piped approximately 5 miles to Salida where they are used in the municipal swimming pool. During the summer some of the waters are used in a swimming pool at the hot springs area. Some of the waters are also used to heat the caretaker's house at the hot springs. In the main spring area only two spring were found that could be sampled, Springs A and B. Both of these "springs" flow from buried pipelines leading into concrete-1 ined junction boxes where the waters are collected and piped to Salida.

Springs $C, D$, and $E$ are located in a separate area approximately $500^{\circ} \mathrm{ft}$ northeast of the main spring area. These three springs are small and unused.

\section{GEOLOGY AND HYDROLOGY:}

Spring A: Temperature: $50^{\circ} \mathrm{C}-71^{\circ} \mathrm{C}$; Discharge: 200 gpm; Total Dissolved Solids: 654 to $697 \mathrm{mg} / 1$; Water Type: sodium bicarbonate-sulfate. Spring $A$, which is a concrete-1ined junction box, is located approximately half the way uphill and on the south side of the travertine apron.

Spring B: Temperature: $66^{\circ} \mathrm{C}$; Discharge: Estimated $30 \mathrm{gpm}$; Total Dissolved Solids: $655 \mathrm{mg} / 1$; Water Type: sodium bicarbonate-sulfate. Spring $B$ is located approximately $140 \mathrm{ft}$ northeast of $A$ and approximately $50 \mathrm{ft}$ higher uphill.

Spring C: Temperature: $62^{\circ} \mathrm{C}$; Discharge: 2 to 4 $\mathrm{m}$; Tota 1 Dissolved Sol ids: 655 to $685 \mathrm{mg} / 1$; Water e: sodium sulfate-bicarbonate type. Spring $C$ is tire easternmost spring.
Spring D: Temperature: $56^{\circ} \mathrm{C}$; Discharge: $2 \mathrm{gpm}$ est.; Conductance: 1,000 micromhos. Spring $D$ is located approximately $40 \mathrm{ft}$ northwest of $C$.

Spring E: Temperature: $60^{\circ} \mathrm{C}$; Discharge: $2 \mathrm{gpm}$ est.; Conductance: 950 micromhos. Spring $E$ is located approximately $20 \mathrm{ft}$ southwest of Spring $D$.

The Poncha Hot Springs, which issue from colluvial deposits overlying the Dry Union Formation, are located at the southern end of the Upper Arkansas River Valley and on the northwest side of the Sangre de Cristo Horst (Knepper, 1976). The geology of the region has been described in detail by a number of authors. Chapin (1971), Knepper (1976), and Van Alstine (1970 and 1974) have all presented excellent summaries of the geology in the immediate vicinity. Chapin (1971) presents a general discussion of the structural development of the Rio Grande Rift Zone. Knepper (1976) presents a detailed discussion of the structural development of the Upper San Luis Valley and the Upper Arkansas River Valley. Knepper (1976) states that the hot springs are located on the northwest end of the Sangre de Cristo Horst, a structurally high area between the two valleys. Van Alstine (1970) states that this part of the horst consists of, in part, blocks of allochthonous Paleozoic rocks that originated to the west in the Sawatch Range. Chapin (1971), Knepper (1976), and Van Alstine (1970) all state that the area around the hot springs is structually complex (Fig. 22). In describing the geologic history of the region, Van Alstine (1970) states that in Late Tertiary time the Upper Arkansas Val ley was connected to the San Luis Valley by a trough along the west edge of the Sangre de Cristo Horst. Chapin (1971) and Knepper (1976) state that faulting began in the region sometime after the close of oligocene time, for 0ligocene rocks along the margins of the valleys have been offset at least $5,000 \mathrm{ft}$ by faulting.

Romero and Fawcett (1978) showed the presence of a resistivity low extending from the Salida area to about 5 miles west of Ponch Springs. This low extends in a north-south direction north over 6 miles from the spring area.

Due to the complexity of the structure in this region, it is difficult to ascertain the origin of the hot springs. The springs are probably fault controlled. Although the area of recharge is not known, the Arkansas River may be the source of the waters. Recharge may also be occurring along the Collegiate and Sawatch Ranges to the west.

GEOTHERMOMETER ANALYSIS: Calculations by Barrett and Pearl (1978) determined that the quartz-silica geothermometer model yields an est imated subsurface temperature of $119^{\circ} \mathrm{C}$ to $137^{\circ} \mathrm{C}$. The quartz mixing model yields an estimated subsurface temperature of $157^{\circ} \mathrm{C}$ to $209^{\circ} \mathrm{C}$ with a cold water fraction of 60 to 73 percent of the spring flow (Table 3 ). 


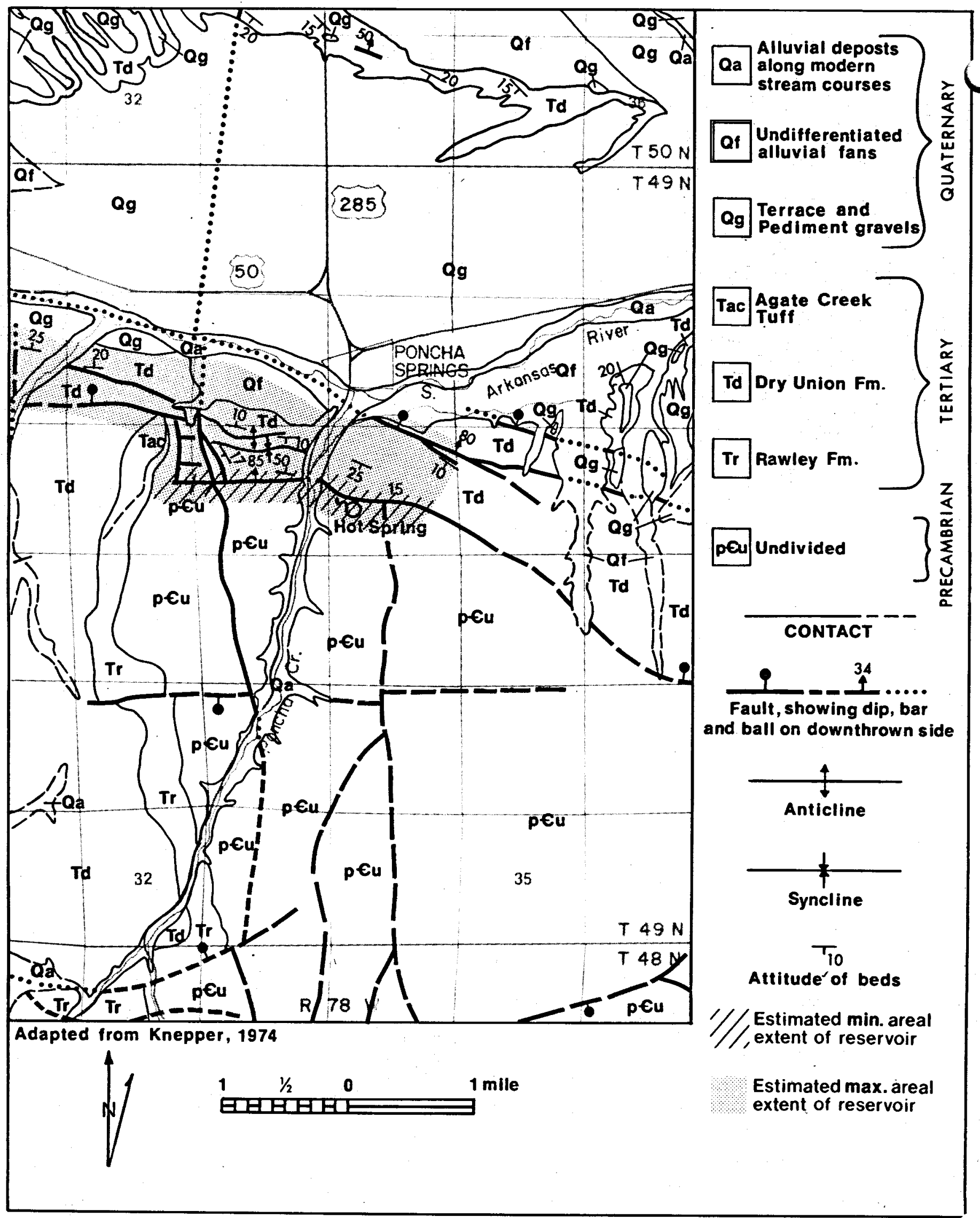

Figure 22.--Map showing geologic conditions surrounding Poncha Hot Springs and estimated extent of the geothermal reservoir. 
Barrett and Pearl (1978), also determined that $\mathrm{Na}-\mathrm{K}$ and $\mathrm{Na}-\mathrm{K}-\mathrm{Ca}$ geothermometers yield surface temperature estimates of $154^{\circ} \mathrm{C}$ to $159^{\circ} \mathrm{C}$ and $96^{\circ} \mathrm{C}$ to $145^{\circ} \mathrm{C}$, respectively. It was noted that extensive travertine deposits occur in the vicinity of these hot springs, and Spring $A$ is currently depositing calcium carbonate within the collection box. Therefore, Barrett and Pearl (1978) felt that the $\mathrm{Na}-\mathrm{K}$ and $\mathrm{Na}-\mathrm{K}-\mathrm{Ca}$ geothermometer estimates were too high.

Conclusion: The best approximation of subsurface temperature is provided by the cristobalite mixing model, and the Na-K-Ca geothermometer which yields a maximum estimate of temperature. Therefore, the temperature at depth in this area is probably within the range of $115^{\circ} \mathrm{C}$ to $145^{\circ} \mathrm{C}$ (Table 3 ).

RESOURCE ASSESSMENT: Due to the complexity of this region and that the reservoir could extend some distance to the west, two estimates of the reservoirs extent were made. The conservative estimate included not only the area around the spring but extended as far west at the fault block. area. Included in this area are some reported warm mud pots west of Poncha Creek. This area is approximately $0.6 \mathrm{sq} \mathrm{mi}$ in extent and may contain .1410 Q's of energy at an average maximum temperature of $145^{\circ} \mathrm{C}$ in a faulted reservoir (Table 2).

The second area includes all of the first area plus an additional $4.47 \mathrm{sq} \mathrm{mi}$. This area extends the reservoir boundaries up the South Fork of the Arkansas River to the west. It is estimated that this reservoir contains 1.1911:Q's of energy at a maximum average temperature of $145^{\circ} \mathrm{C}$.

Romero and Fawcett (1978) estimated that this system could contain as much as $38.10 Q^{\prime}$ 's of heat energy, considerably more than here estimated. This is because their estimates were based on different parameters than those used by the author. 


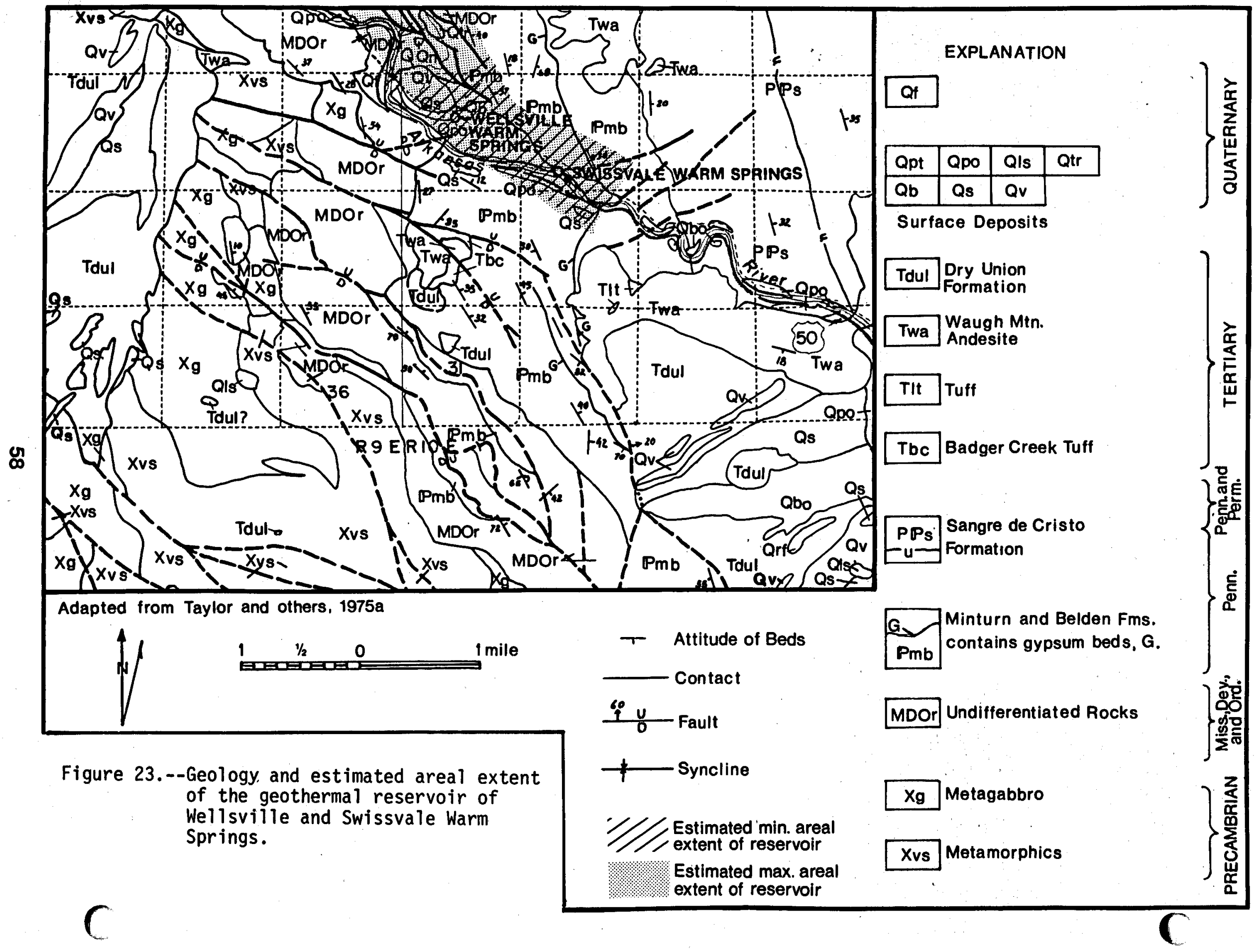




\section{\#24 WELLSVILLE WARM SPRING}

LOCATION: Latitude: $38^{\circ} 29^{\prime} 07^{\prime \prime N}$; Longitude: $105^{\circ} 54^{\prime} 36$ "W.; T. 49 N., R. 10 E., Sec. 18 -, N.M.P.M.; Chaffee County; Howard, 15-minute topographic quadrangle map.

GENERAL: Barrett and Pearl (1978), stated that this large warm spring is located on the north bank of the Arkansas River approximately 6 miles east of Salida. Waters from the spring are used in tropical fish-rearing ponds. Algae and tropical plants are also grown commercially in some of the ponds.

GEOLOGY AND HYOROLOGY: The temperature of the waters ranged from $28^{\circ} \mathrm{C}$ to $33^{\circ} \mathrm{C}$ in a year's time. The discharge varied from 160 to $200 \mathrm{gpm}$. The total dissolved solids content range from $470 \mathrm{mg} / 1$ to $484 \mathrm{mg} / 1$. The waters are a calcium bicarbonate type.

As shown on the accompanying geologic map (Fig. 23), the Wellsville Warm Spring is located on a small northeast-trending fault. While the bedrock has been mapped as undivided Mississippian, Devonian, and Ordovician sedimentary formations, the waters come from the Leadville Limestone. Due to the erosional history of the Arkansas River and faulting, only a small remnant of Leadville Limestone is present.

No attempt was made to decipher the hydrogeological cond it ions surround ing this spring, but the waters may be recharged from the high ground either to the north or to the south. The springs are located on the extreme edge of the Rio Grande rift zone. Reiter (1975), states that the area has a heat flow of just below $2.0 \mathrm{H} . \mathrm{F} . \mathrm{U}$. The origin of the heat is unknown.:

GEOTHERMOMETER ANALYSES: Calculations determined that cristobalite controls the silica content of the warm spring (Barrett and Pearl, 1978). The cristobalite-silica geothermometer model yields a temperature of $30^{\circ} \mathrm{C}$ to $31^{\circ} \mathrm{C}$ (Table 3 ) which is the same as the surface temperature of the warm spring. Analys is suggests that this geothermometer estimate is close to the actual temperature at depth (Barrett and Pearl, 1978).

Cristobalite mixing model analysis yields a subsurface temperature estimate of $33^{\circ} \mathrm{C}$ with a cold water fraction of 2 to 15 percent of the spring flow.

The $\mathrm{Na}-\mathrm{K}$ and $\mathrm{Na}-\mathrm{K}-\mathrm{Ca}$ geothermometers yield subsurface temperature estimates of $213^{\circ} \mathrm{C}$ to $216^{\circ} \mathrm{C}$ and $48^{\circ} \mathrm{C}$ to $50^{\circ} \mathrm{C}$, respectively (Table 3 ) which are probably high.

Conclusion: The high flow, and excellent agreement between the silica geothermometer and mixing models with the silica content and temperature of the warm spring suggest that the temperature at depth is near the surface temperature of the warm spring. Therefore, the subsurface temperature is near $35^{\circ} \mathrm{C}$ and certainly between $35^{\circ} \mathrm{C}$ to $50^{\circ} \mathrm{C}$ (Table 3 ).

RESOURCE ASSESSMENT: See Resource Assessment of Swissavle Warm Springs. 


\section{\#25 SWISSVALE WARM SPRINGS}

LOCATION: Latitude: $38^{\circ} 28^{\prime} 49^{\prime \prime N}$.; Longitude: $105^{\circ} 53^{\prime} 25^{\prime \prime W}$; T. 49 N., R. 10 E., Sec. 20 cda, N.M.P.M.; Fremont County; Howard 15-minute topographic quadrangle map.

GENERAL: This group of nine unused springs is Tocated along the north bank of the Arkansas River approximately 6.5 miles east of Salida. Field measurements were made at the two largest springs in the group: Spring $A$, the largest and easternmost spring, is located $30 \mathrm{ft}$ south of a U.S. Bureau of Land Management cadastral survey marker. Spring $F$ is located approximately $350 \mathrm{ft}$ west of Spring $A$ and about $20 \mathrm{ft}$ above the river bank.

GEOLOGY AND HYDROLOGY: Spring A has a temperature of $28^{\circ} \mathrm{C}$, a discharge of $125 \mathrm{gpm}$ with a conductance of 880 micromhos. Spring $F$ has a temperature of $20^{\circ} \mathrm{C}$, a discharge estimated at 20 gallons per minute, and a specific conductance of 775 micromhos. Total discharge of all springs is approximately $200 \mathrm{gpm}$.

As shown on Figure 23, the waters come from the Pennsylvanian Maroon and Belden Formations. These formations dip to the northeast and are cut by a north-northeast trending fault less than 1 mile to the east. Taylor and others (1976) mapped numerous major southeast-trending faults to the south, southwest, and northwest of the spring. None were projected into the spring area; however, one north-trending fault was mapped less than 1 mile east of the springs. The thermal waters may migrate up one of these faults into the fracture zones within the Maroon Formation.

GEOTHERMOMETER ANALYSES: The cristobalite-silica geothermometer model yields a subsurface temperature estimate of $32^{\circ} \mathrm{C}$, which is near the surface temperature of the warm springs $\left(28^{\circ} \mathrm{C}\right)$. The cristobalite mixing model yields a subsurface temperature estimate of $35^{\circ} \mathrm{C}$ to $47^{\circ} \mathrm{C}$ with a cold-water fraction of 22 percent to 69 percent of the spring flow (Table 3 ).

$\mathrm{Na}-\mathrm{K}$ and $\mathrm{Na}-\mathrm{K}-\mathrm{Ca}$ Geothermometers: The $\mathrm{Na}-\mathrm{K}$ and $\mathrm{Na-K}-\mathrm{Ca}$ geothermometers yield subsurface temperature estimates of $214^{\circ} \mathrm{C}$ and $44^{\circ} \mathrm{C}$ to $48^{\circ} \mathrm{C}$, respectively (Table 3 ).

Conclusion: The high flow and the excellent agreement between the silica geothermometer and mixing model estimates suggest that the temperature at depth is near the surface temperature of the warm springs. Therefore, the subsurface temperature in this area is probably near $35^{\circ} \mathrm{C}$ and certainly between $35^{\circ} \mathrm{C}$ and $50^{\circ} \mathrm{C}$ (Table 3 ).

RESOURCE ASSESSMENT OF WELLSVILLE-SWISSVALE WARM SPRINGS: Since the geologic conditions surrounding the Wellsville and Swissvale Springs are nearly identical, they are here considered as one reservoir unit for resource assessment purposes. Upon appraising the regional geologic conditions of the area, it appears that the areal extent of the reservoir could include $0.94 \mathrm{sq} \mathrm{mi}$. The faulted area to the west of Wellsville (Fig. 23) might have some controlling influence on the occurrence of the springs. If this area is included in the areal extent of the reservoir it would include $1.66 \mathrm{sq} \mathrm{mi}$. The reservoir is estimated to be within sedimentary rocks, with the waters probably associated with the Leadville Limestone or one of the older carbonate rocks. The energy content of the system is estimated to range from $.0085 Q^{\prime} s$ to $.0150 Q^{\prime} s$ at an average maximum temperature of $40^{\circ} \mathrm{C}$ (Table 2 ). 


\section{\#26 CANON CITY HOT SPRINGS}

LOCATION: Latitude: $38^{\circ} 25^{\prime} 57^{\prime N}$.: Longitude: $105^{\circ} 15^{\prime} 46^{\prime \prime W}$.; T. 18S., R.70 W., Sec. 31 d, 6th P.M.; Fremont County; Royal Gorge 7 1/2-minute topographic quadrangle map.

GENERAL: The spring is located in the front yard of the house at 1400 Riverside Drive in Canon City. The spring, located at the southeast corner of the abandoned swimming pool, is cased wih a 6-in. diameter pipe to a depth of $50 \mathrm{ft}$.

In the summer of 1979 two other artesian thermal wells were located in the Canon City area. Other than measuring the water temperature no effort was made at that time to sample the waters for contained mineral matter or measure the discharge accurately. These thermal wells are described in Table 6 at the end of the paper.

GEOLOGY AND HYDROLOGY: This unused spring has a discharge estimated to be $5 \mathrm{gpm}$ with a temperature of $40^{\circ} \mathrm{C}$. The total dissolved solids content of the water is $1,230 \mathrm{mg} / 1$.

The spring is located at the contact between the Leadville Limestone and the overlying Fountain Formation (Fig. 24). No faults have been mapped in the vicinity of the spring, and none are apparent on the surface. Therefore, the waters must ascend through the Leadville Limestone. The recharge area for this spring is probabiy to the north and east along the northern flanks of the Canon City Embayment.

GEOTHERMOMETER ANALYSES: Geothermometer model $s$ are not reliable when applied to the Canon City Hot
Springs because many of the assumptions inherent in their use are violated. Barrett and Pearl (1978) did however, calculate the subsurface temperatures. The chalcedony-silica geothermometer yielded a subsurface temperature estimate. of $34^{\circ} \mathrm{C}$ to $35^{\circ} \mathrm{C}$, which is below the surface temperature of the thermal spring $\left(40^{\circ} \mathrm{C}\right)$. This low temperature estimate may be caused by mixing of the ascending thermal water and dilute ground water.

The, chalcedony mixing model yields a subsurface temperature estimate of $38^{\circ} \mathrm{C}$ to $40^{\circ} \mathrm{C}$ with a cold-water fraction of 3 to 12 percent of the total flow (Barrett and Pearl, 1978). These estimates are well within the range of values that could result from normal analytical error.

The $\mathrm{Na}-\mathrm{K}$ ar.d $\mathrm{Na}-\mathrm{K}-\mathrm{Ca}$ geothermometers estimates are $187^{\circ} \mathrm{C}$ and $68^{\circ} \mathrm{C}$ to $72^{\circ} \mathrm{C}$, respectively. These estimates are too high because calcium carbonate is deposited on the well casing.

Barrett and Pearl (1978) noted that upon analysis of the data it appears that no reliable estimate of the subsurface temperature is possible.

RESOURCE ASSESSMENT: It is estimated that this sedimentary reservoir is restricted to an area of approximately $.50 \mathrm{sq} \mathrm{mi,} \mathrm{primarily} \mathrm{to} \mathrm{the} \mathrm{east} \mathrm{of}$ the spring. Calculations based on a reservoir of this size with an average maximum temperature of $50^{\circ} \mathrm{C}$ shows that there maybe $.0028 Q^{\prime} \mathrm{s}$ of heat energy contained in the system (Table 2 ). 


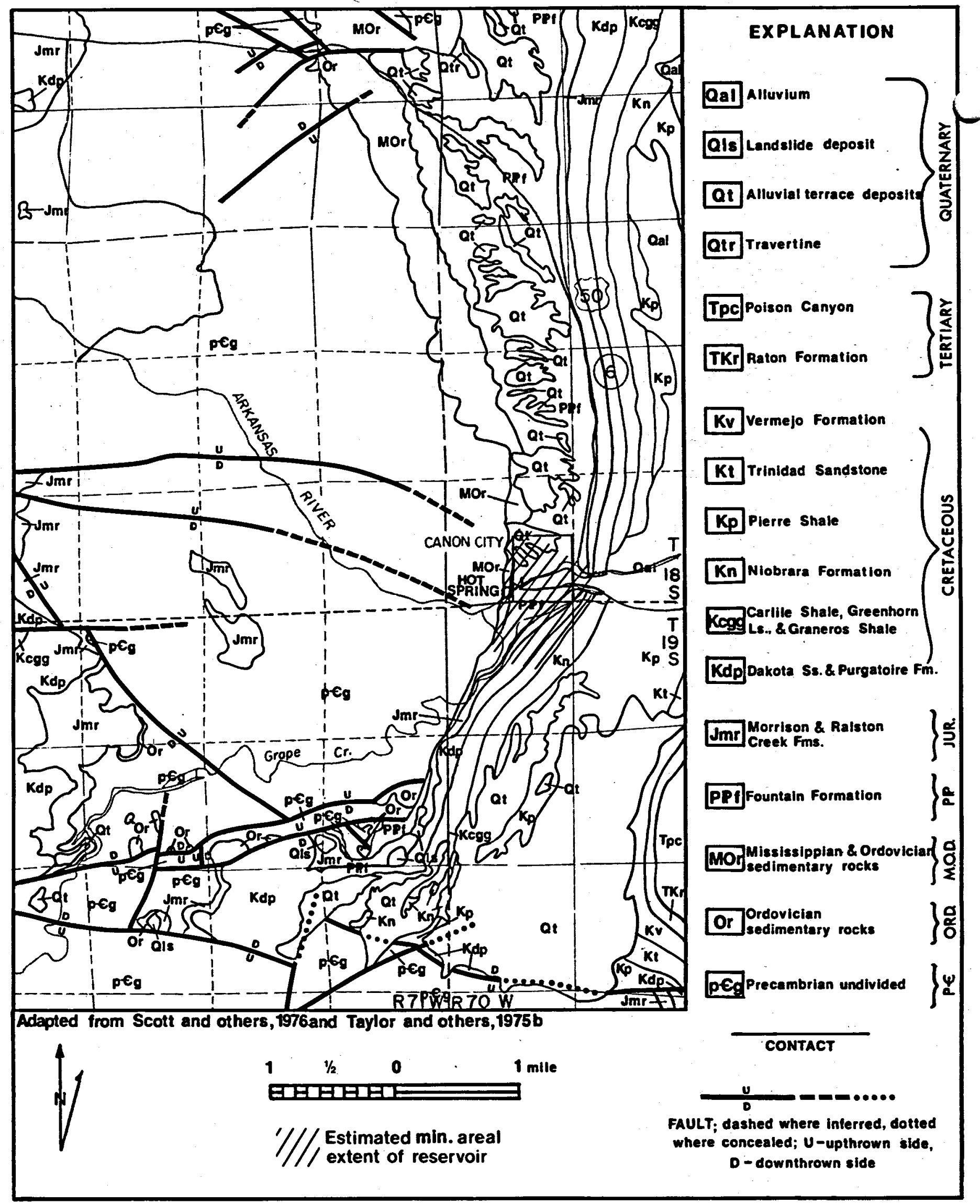

Figure 24.--Geology of Canon City region and estimated areal extent of the geothermal reservoir. 


\section{\#27 FREEMONT NATATORIUM WELL}

LOCATION: Latitude: $38^{\circ} 27^{\prime} 38^{\prime N} \mathrm{~N}$; Longitude: $105^{\circ} 11^{1} 46$ "W.; T. 18 S., R. 70 W., Sec, 26 bbb, 6th P.M.: Fremont County; Canon City 7 1/2-minute topographic quadrangle map.

GENERAL: This 1,800-ft-deep artesian well is located at 3095 Central Avenue in northeast Canon City (Barrett and Pearl, 1978). The well, which supplied waters to the pool at the natatorium, is just behind the unused swimming pool north of the bend in the road.

As noted earlier several other existing wells in the Canon City area were located in the Canon City area during the summer of 1979. For a description of these wells see table 6 .

GEOLOGY AND HYDROLOGY: Barrett and Pearl (1978) noted that the temperature of the waters is $35^{\circ} \mathrm{C}$ with a discharge of $20 \mathrm{gpm}$. The total dissolved solids content varied from $1,300 \mathrm{mg} / 1$ to a high of $1,370 \mathrm{mg} / 1$ throughout a year's time.

This well is located on the west side of the Canon City Embayment and the bedrock of the area is the Cretaceous Pierre Shale. As noted on the geologic map (Fig. 25), no faults or folds occur in the immediate vicinity of this well.

The depth of the well suggests that the waters come from the Dakota Formation, which is the principal aquifer in the Canon City Embayment. Recharge probably occurs to the north around the flanks of the embayment with the heating of the waters caused by decay of radioactive minerals. The Dakota Formation in western portions of the
Canon City Embayment contains above-normal concentrations of radioactive minerals (Richard Gamewel1, 1975, oral communication, and Vinickier, 1978).

GEOTHERMOMETER ANALYSES: Calculations by Barrett and Pearl (1978) determined the following subsurface temperatures: Quartz-silica, $50^{\circ} \mathrm{C}$, Chalcedony-silica, $23^{\circ} \mathrm{C}$, Quartz mixing model, $78^{\circ} \mathrm{C}$ to $88^{\circ} \mathrm{C}$ with a cold water fraction of 63 to 69 percent. These estimates are probably too high because both the silica content and the flow rate of the artesian well are below the minimum conditions specified for the reliable application of this geothermometer. 0ther geothermometer estimates of the subsurface temperature are: Chalcedony mixing model, $32^{\circ} \mathrm{C}$ with a cold water fraction of 23 percent of the total flow, and $\mathrm{Na}-\mathrm{K}$ and $\mathrm{Na}-\mathrm{K}-\mathrm{Ca}, 174^{\circ} \mathrm{C}$ and $73^{\circ} \mathrm{C}$, respectively. Both of these estimates are too high because calcium carbonate is being deposited around the well.

The subsurface temperature in this area is probably between the surface temperature of the artesian well and the quartz silica geothermometer estimate, namely $35^{\circ} \mathrm{C}$ to $50^{\circ} \mathrm{C}$ (Table 3 ).

RESOURCE ASSESSMENT: Due to the uncertainty of the geologic control of these thermal waters it was assumed that the waters are coming from the Dakota Formation and are restricted to an area of approximately $1.0 \mathrm{sq} \mathrm{mi}$ around the well. The calculated amount of heat energy contained in this system is $.0095 Q^{\prime}$ s at an average maximum temperature of $43^{\circ} \mathrm{C}$ (Table 2$)$. 


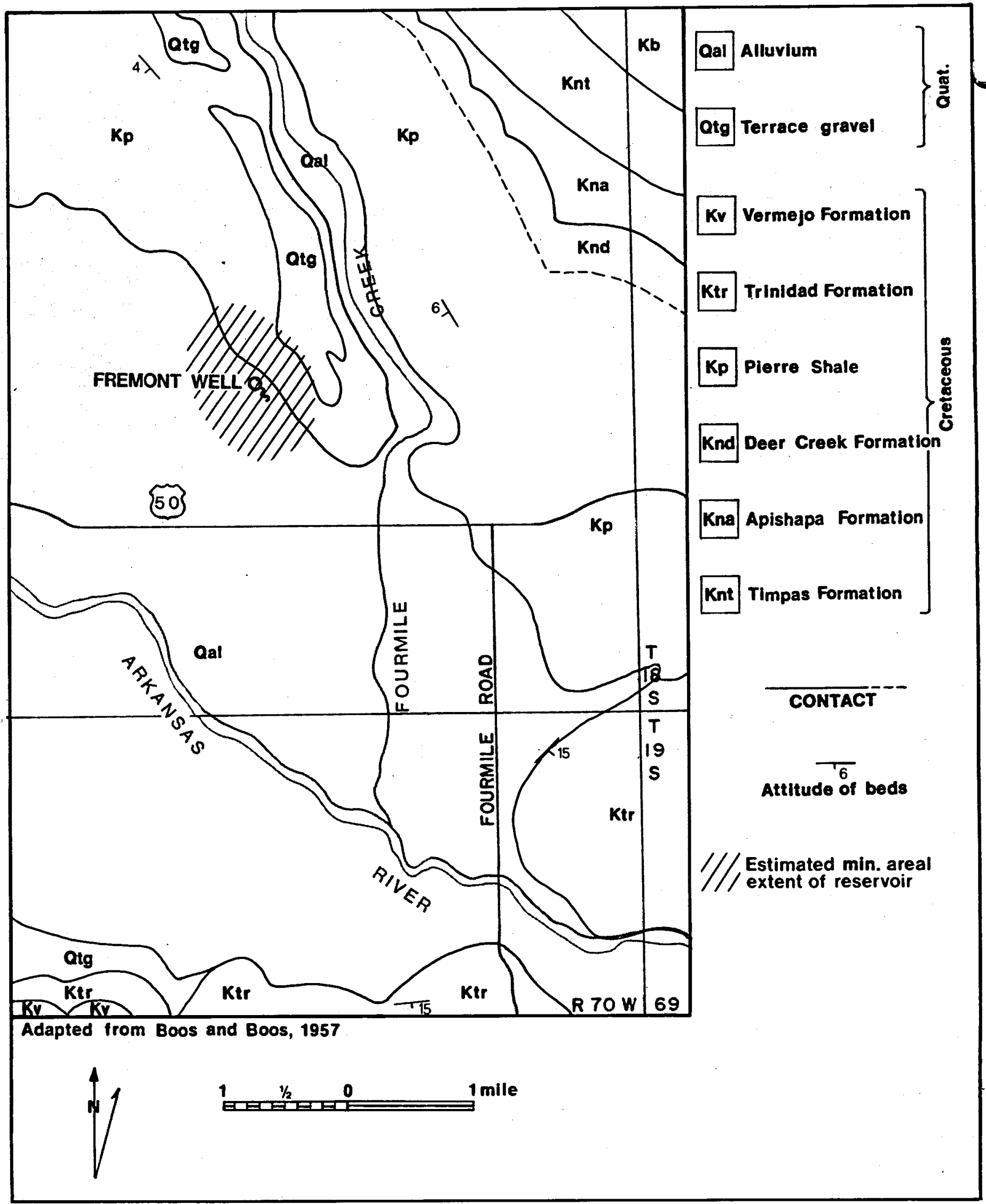

Figure 25.--Map showing estimated areal extent of the Fremont Natatorium geothermal reservoir and surrounding geologic conditions. 


\title{
\# 28 PENROSE ARTESIAN WELL
}

\author{
(FORMERLY FLORENCE ARTESIAN WELL)
}

LOCATION: Latitude: $38^{\circ} 24^{\prime} 53^{\prime \prime N}$.; Longitude: $105^{\circ} 0243^{\prime \prime W}$; T. 19 S., R. 68 W., Sec. 7 bac; 6 th P.M.; Fremont County; Florence 7 1/2-minute topographic quadrangle map.

GENERAL: Barrett and Pearl (1978) mislocated and misnamed this well in their report. To correct that error the well is here renamed the Penrose Artesian Well. This unused well of unknown depth is located approximately $1,800 \mathrm{ft}$ southwest of the junction of U.S. 50 and Colorado 115 south of Penrose. The well is located on the east side of Colorado 115 and southwest of an abandoned farm building.

During the summer of 1979 two other artesian thermal wells were located in the Penrose area and one in the Florence area. No attempt was made at that time to either accurately measure the discharge of the wells or have the waters analyzed for contained mineral matter. These wells are described in Table 6 at the end of the paper.

GEOLOGY AND HYOROLOGY: The waters have a surface temperature of $28^{\circ} \mathrm{C}$, with a discharge of $130 \mathrm{gpm}$. The waters contain $1,480 \mathrm{mg} / 1$ of dissolved solids, and the waters are a sodium-bicarbonate type (Barrett and Pearl, 1978).

This:well is located in the Canyon City Embayment. The bedrock of the area is the Niobrara Fm., and no major structural features are present in the area (Fig. 26). The depth of the well is unknown, but the waters probably come from the Dakota Formation, which is the main aquifer in the Canyon City Embayment. The origin of the heat is unknown but may be related to decay of radioactive minerals in the Dakota Formation (see Clark Artesian Well discussion).
GEOTHERMOMETER ANALYSES: Calculations show that chalcedony controls the silica content of the artesian well. The chalcedony-silica geothermometer model gave an estimated subsurface temperature of $34^{\circ} \mathrm{C}$.

Chalcedony mixing model analysis yields a subsurface temperature estimate of $41^{\circ} \mathrm{C}$ with a cold water fraction of 40 percent of the total flow (Barrett and Pearl, 1978).

The $\mathrm{Na}-\mathrm{K}$ and $\mathrm{Na}-\mathrm{K}-\mathrm{Ca}$ geothermometers yield subsurface temperature estimates of $212^{\circ} \mathrm{C}$ and $178^{\circ} \mathrm{C}$, respectively. The $\mathrm{Na}-\mathrm{K}$ geothermometer estimate is too high because the conditions of the model are violated. Moroever, the high magnesium content $(78 \mathrm{mg} / 1)$ of the waters makes geothermometers unreliable.

Most geothermometers are not reliable when applied to Florence Artesian Well because many of the assumptions inherent in their use are violated. Therefore, the most likely subsurface temperature in this area is between $34^{\circ} \mathrm{C}$ and $50^{\circ} \mathrm{C}$ (Table 3 ).

RESOURCE ASSESSMENT: Vinckier (1978) has shown the occurrence of faulting in the vicinity of this we11. Therefore, even though it is estimated that the reservoir is a stratigraphic reservoir two estimates of the reservoirs areal extent were made based on the occurrence of the faults. One was a conservative estimate of $1.0 \mathrm{sq} \mathrm{mi}$ and included only the area around the spring. The other estimate, of $5.2 \mathrm{sq} \mathrm{mi}$ in extent, was drawn to try to include some of the faulting. Calculated heat energy contained in this system varied from .0083 $Q$ 's to $.0430 Q^{\prime}$ 's at an average maximum temperature of $43^{\circ} \mathrm{C}$ (Table 2$)$. 


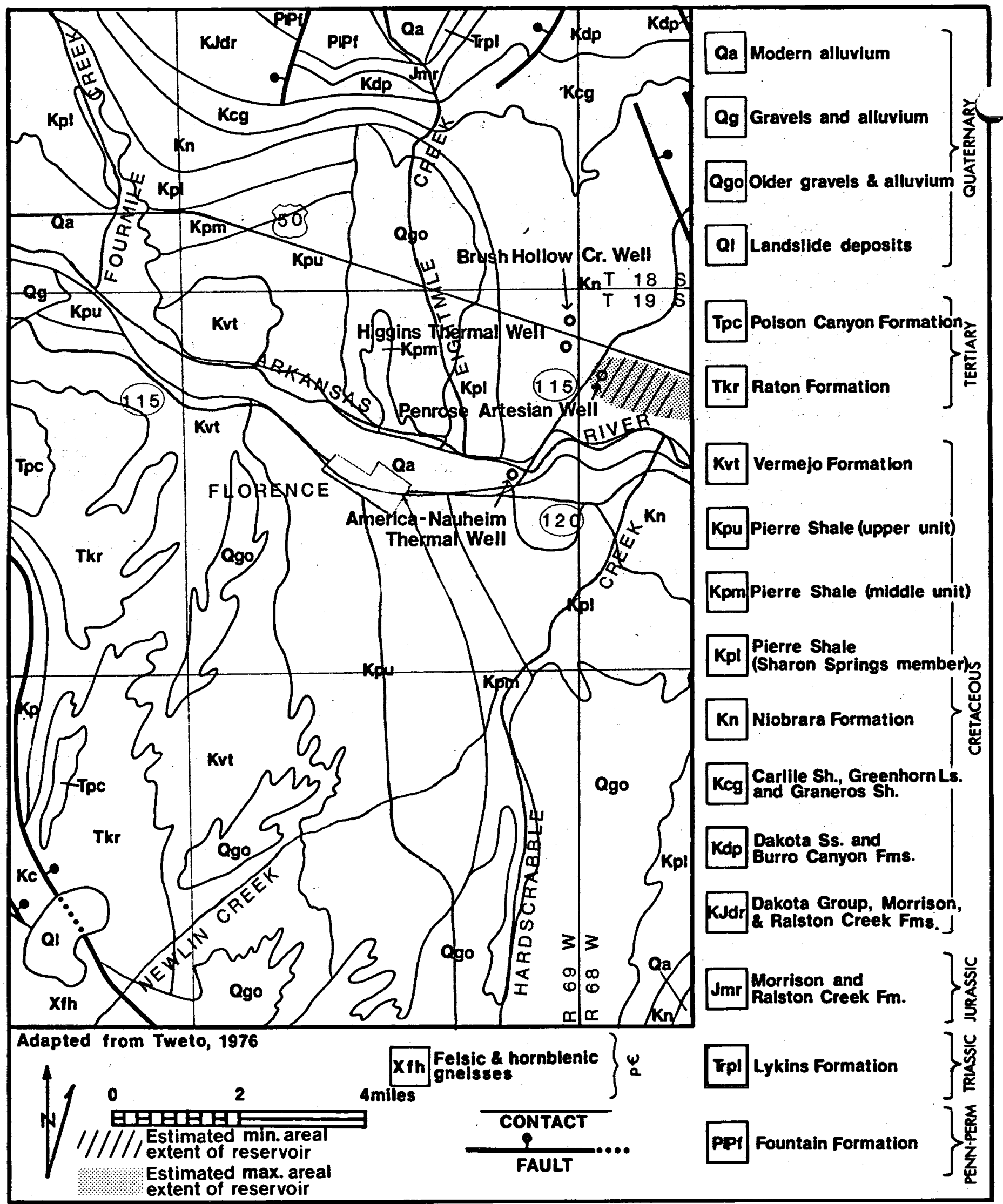

Figure 26.--Geology of the Florence area and estimated areal extent of the Penrose Artesian Well geothermal reservoir. 


\section{\#29 DON K RANCH ARTESIAN WELL}

LOCATION: Latitude: $38^{\prime} 10^{\circ} 20^{\prime N}$.; Longitude: $105^{\circ} 00^{\prime} 32$ "W.; T. 22 S., R. 68 W., Sec. 5 a, 6 th P.M.; Fremont County; Wetmore 7 1/2-minute topographic quadrangle map.

GENERAL: This unused well, of unknown depth, may be reached by going west from Pueblo for approximately $19.5 \mathrm{miles}$ on State Highway 96 to the community of Siloam. At Siloam turn left on a dirt road, called Siloam Road, and go approximately 4.75 miles to the turnoff to the Don K. Ranch. Follow this road for approximately one mile to the ranch house.

GEOLOGY AND HYDROLOGY: The waters of this well have a surface temperature of $28^{\circ} \mathrm{C}$ and a discharge of $25 \mathrm{gpm}$. The total dissolved solids of the waters are $1,710 \mathrm{mg} / 1$, and the waters are a sodium bicarbonate type.

The well is located down on the northeast flank of the Red Anticline (Fig. 27). The bedrock of the area is the Pennsylvanian Fountain Formation. Taylor and Scott (1973) mapped no faults in the area. On the crest of the anticline, approximately one mile to the southwest, Precambrian biotite gneiss crops out. No attempt was made to determine the origin of the thermal waters or the heat source; however, a cursory appraisal suggests that heat lensing occurs within the Precambrian metamorphic rocks. Dr. Trobe Grose (1977, oral communication) states that "heat lensing" can occur when a granitic or metamorphic rock body is overlain by a sedimentary sequence. Because sedimentary rocks have lower specific heat content than the granitic or metamorphic rocks, the heat is drawn to and concentrated in the metamorphic and granitic rocks.

GEOTHERMOMETER ANALYSES: The sil ica content of this artesian well does not approach the solubility of amorphous silica, chalcedony, cristobalite or quartz; therefore, application of any of these silica geothermometers yields questionable results (Barrett and Pearl, 1978).
The cristobalite-silica geothermometer model yielded an estimated subsurface temperature of $42^{\circ} \mathrm{C}$. However, this estimate is probably too high because the theoretical cristobal ite solubility (29 $\mathrm{mg} / 1$ ) at the surface temperature of the we11 $\left(28^{\circ} \mathrm{C}\right.$ ) is below the silica content of the thermal water $(40 \mathrm{mg} / 1)$.

Mixing model analysis is unreliable when applied to the thermal waters in this well because the temperature and flow of well are below the minimum conditions specified for the reliable use of this model. The amorphous silica mixing model yields a subsurface temperature estimate of $23^{\circ} \mathrm{C}$ with a cold-water fraction of 47 percent of the artesian flow. The cristobalite mixing model yields a subsurface temperature estimate of $63^{\circ} \mathrm{C}$ with a cold water content of 61 percent.

The $\mathrm{Na}-\mathrm{K}$ and $\mathrm{Na}-\mathrm{K}-\mathrm{Ca}$ geothermometers yield subsurface temperature estimates of $219^{\circ} \mathrm{C}$ and $190^{\circ} \mathrm{C}$, respectively. Both of these estimates are too high because calcium bicarbonate is deposited on the well casing.

Conclusion: Geothermometer analys is for this area is not reliable because most of the assumptions do not apply.

RESOURCE ASSESSMENT: The occurrence of this thermal water is not fully understood and should probably be classified as unkown. However, to try to estimate the areal extent of the reservoir, it was hypothesized that faulting to the west may play some part in the occurrence of the thermal waters. Therefore, it was assumed that the waters are moving up from depth along the fault then down dip in some sedimentary formation. Thus, the reservoir was estimated to extend east from the fault for a distance of over 2 miles and encompassed an area of approximately $1.5 \mathrm{sq} \mathrm{mi}$ ( $\mathrm{Fig}$. 27). If this estimate is correct, the reservoir could contain $.0353 \mathrm{Q}$ 's of energy at an average maximum temperature of $40^{\circ} \mathrm{C}$ (Table 2$)$. 


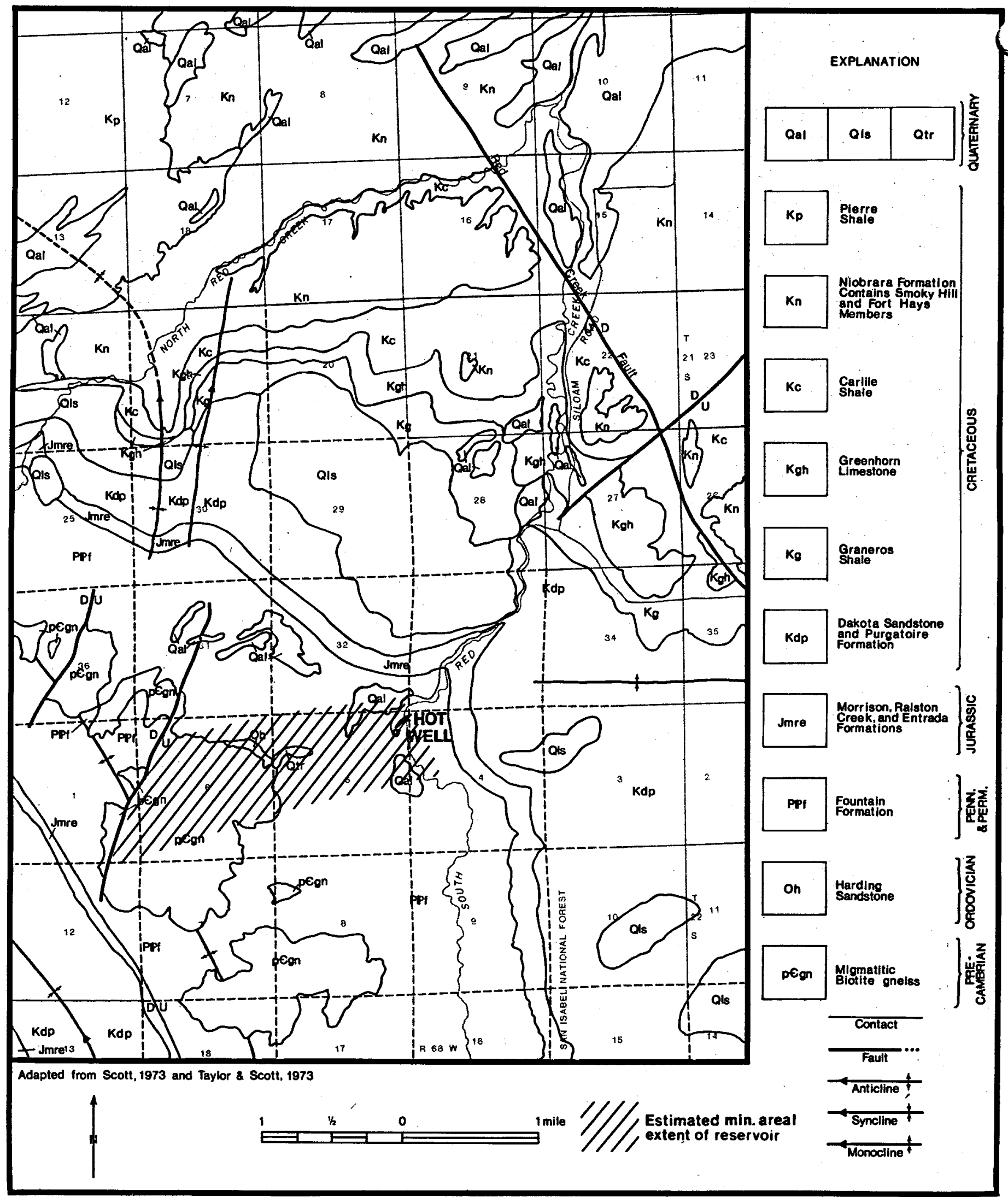

Figure 27.--Don K Ranch area, geology and estimated areal extent of the geothermal reservoir. 


\section{\#30 CLARK ARTESIAN WELL}

\section{(CLARK SPRING WARM WATER WEL)}

LOCATION: Latitude: $38^{\circ} 15^{\prime} 29^{\prime \prime} \mathrm{N}_{\text {.; }}$ : Longitude: $104^{\circ} 36^{\top} 35^{\prime \prime} W_{\text {.; }}$ T. 21 S., R. 65 W.; Sec. 1 aab, 6th P.M.; Pueblo County; NE Pueblo 7 1/2-minute topographic quadrangle map.

GENERAL: This well is located inside the Clark Spring Water Company building on the north corner of Clark and B Streets in Pueblo, Colorado. The waters are bottled and sold commercially by the Clark Spring Water Company.

GEOLOGY AND HYDROLOGY: This well is $1,412 \mathrm{ft}$ deep. The waters, which issue at the surface with a temperature of $25^{\circ} \mathrm{C}$, contain $1,210 \mathrm{mg} / 1$ of dissolved mineral matter and are a sodium sulfate type.

As shown on Figure 28 , the well is located on the southwest flank of an unnamed syncline. The origin of the thermal waters is unknown but may be caused by decay of radioactive minerals in the Dakota Formation. Richard Gamewell (1977, oral communication), a radiological specialist for the Colorado Department of Health, and Vinickier (1978) have reported elevated levels of radioactivity in the Pueblo area associated with ground waters from the Dakota and other Cretaceous formations.

Recharge to the Dakota Formation occurs primarily along the flanks of the Canon City Embayment to the west of Pueblo.

GEOTHERMOMETER ANALYSES: Barrett and Pearl (1978) noted that most geothermometer models are not reliable for estimating the Clark Artesian Well reservoir temperature because many of the assumptions inherent in their use are violated. The quartz-silica geothermometer model yielded a subsurface temperature of $40^{\circ} \mathrm{C}$.

The quartz mixing model yielded a subsurface temperature estimate of $61^{\circ} \mathrm{C}$ with a cold water fraction of 65 percent of the total flow. Any estimates of subsurface temperatures with this model are unreliable because the silica content (11 $\mathrm{mg} / \mathrm{l}$ ) and the flow of this well are below the minimum conditions specified for the reliable application of this geothermometer (Barrett and Pearl, 1978).

The Na-K and Na-K-Ca geothermometers yield subsurface temperature estimates of $280^{\circ} \mathrm{C}$ and $159^{\circ} \mathrm{C}$, respectively. The high magnesium content (45 mg/1), low surface temperature and flow of this well and the lack of substantiation of such high subsurface temperatures by the other geothermometers render these est imates unreliable.

Conclusion: From analysis of all the data, it appears that the most likely subsurface temperature in this area is between $25^{\circ} \mathrm{C}$ and $50^{\circ} \mathrm{C}$ (Table 3 ).

RESOURCE ASSESSMENT: Because of the uncertainty concerning the origin and geological controls of this hot water, the boundries of the reservoir were drawn to include only a small area around the well. As drawn the reservoir encompasses some $1.1 \mathrm{sq} \mathrm{mi}$ and contains .0083 Q's of heat energy at an average temperature of $40^{\circ} \mathrm{C}$ (Table 3 ). 


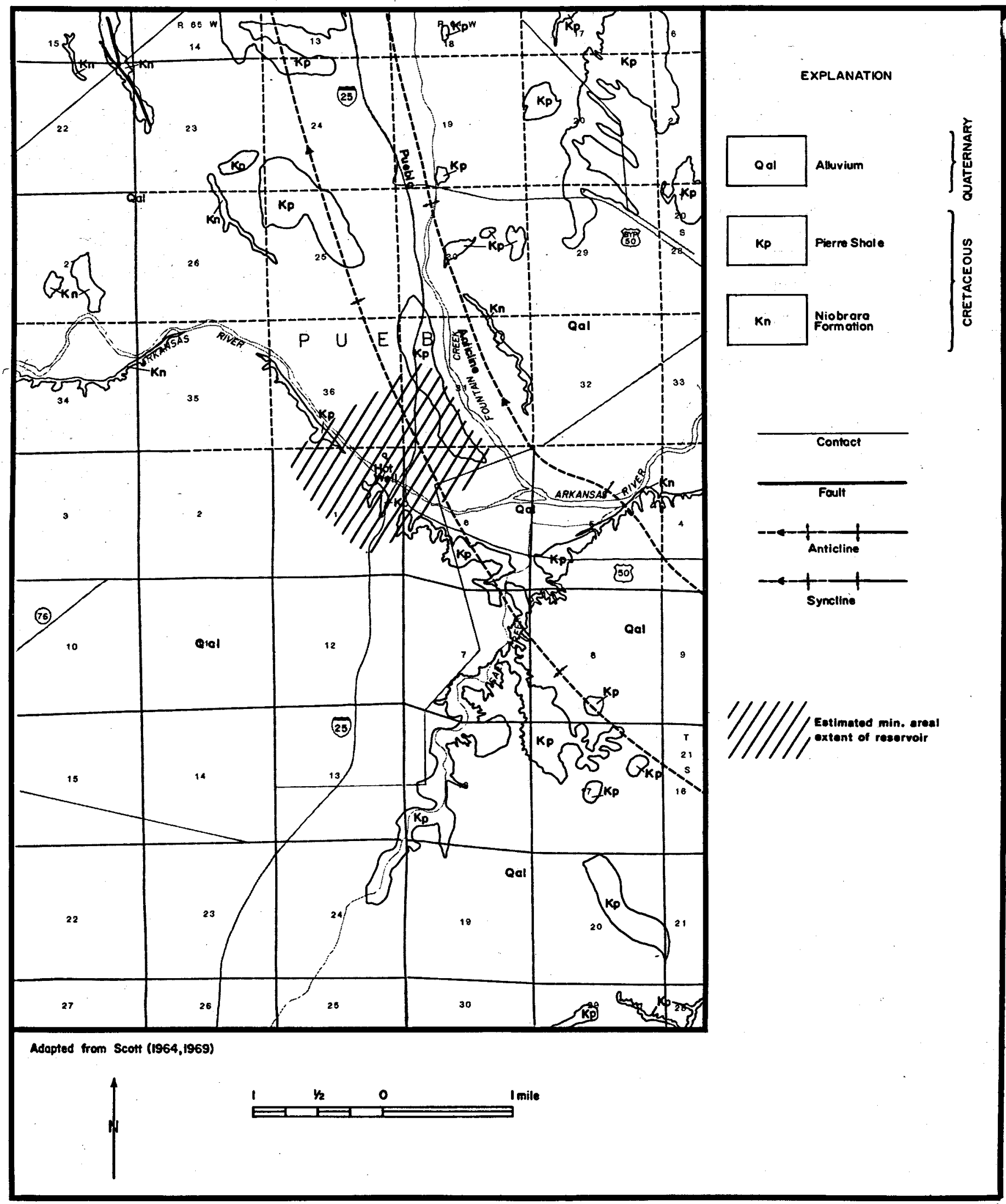

Figure 28.--Map showing estimated areal extent of the Clark Artesian Well geothermal reservoir and surrounding geologic conditions. 


\section{\#31 MINERAL HOT HOT SPRINGS}

LOCATION: Latitude: $38^{\circ} 10^{\prime} 08^{\prime \prime} \mathrm{N}_{.} ;$Longitude: 105०55.05"W.; T. 45 N., R. 9 E., Sec. 12 ad, N.M.P.M.; Saguache County; Villa Grove 7 1/2-minute topographic quadrangle map.

GENERAL: The Mineral Hot Springs consists of a number of unused springs scattered over approximately 80 acres just east of Colorado 17 , 6.5 miles south of Villa Grove in the northern San Luis Valley.

These unused springs are located in three groups--an eastern group of two springs and one well, a central group of one spring, and one seep in a western group. Development of the area has reduced the many springs around the travertine mound to just one seep and the main spring, which flows into a concrete-lined cistern (Barrett and Pearl, 1978).

GEOLOGY AND HYDROLOGY: The waters of all the springs are quite similar. The temperature of the springs is $60^{\circ} \mathrm{C}$, and the total dissolved solids content is approximately $650 \mathrm{mg} / 1$ (varies slightly throughout the year's time). The waters are a sodium bicarbonate type.

Spring $A$, which is actually a well, has the largest discharge of all the springs: Its discharge ranges between 70 and $167 \mathrm{gpm}$ throughout the year. Spring A comprises almost all of the discharge of the easternmost group of three springs. The other two are seeps having a discharge of 1 to $2 \mathrm{gpm}$. Spring $D$, which is the large spring flowing into the concrete-lined cistern in the center group, has an estimated discharge of $5 \mathrm{gpm}$.

The Mineral Hot Springs are located in the. northern end of the San Luis Valley, a part of the Rio Grande rift zone. There are no surface expressions of any fault systems crossing this area: However, several authors have projected one and possibly two faults in the vicinity of the springs (Fig. 29). It has been postulated that a northwest-trending fault extends from the Bonanza area as far east as the Mineral Hot Springs area. This theory was confirmed by students from the Department of Geophysical Engineering, Colorado School of Mines, who conducted a geophysical investigation in this area during the suminer of 1977. Their work showed that the springs are located at the intersection of two fault zones (Dr. George Keller, 1977 , oral communication). During the course of their investigation a small-diameter hole, located almost due west of Spring $A$ and due north of Spring D, was drilled to a depth of 320 ft. This well encountered ground waters under artesian conditions. The flow of the well established at 2 to $5 \mathrm{gpm}$, and the waters had a temperature of $38^{\circ} \mathrm{C}$. The thermal waters appear to no narrowly restricted because less than $1 / 2$ mile ) the east of the Spring $A$ there is a cold ground-water well.
The area is underlain by thick valley-fill alluvium. Dr. George Keller (1977, oral communication) reported that the 1977 geophysical investigations showed up to $5,000 \mathrm{ft}$ of alluvium just a few hundred $\mathrm{ft}$ north of the springs. At Spring $D$ the bedrock is very close to the surface, thus implying a rapid southwest elevation of the bedrock surface or a large normal fault.

In addition to the geophysical investigations by the Colorado School of Mines in 1977, the Colorado Division of Water Resources did extensive geophysical and test drilling in the vicinity of Mineral and Valley View Hot Springs during the winter and summer of 1976 (Romero and Fawcett, 1978). This investigation showed that the valley floor is approximately $5,000 \mathrm{ft}$ deep in the vicinity of Mineral and Valley View Hot Springs and is cut by numerous high angle normal faults.

It is believed that the Mineral Hot Springs represent deep circulation of ground waters through fault zones in a region of above-normal heat flow (Reiter, 1975). Another possible explanation for this thermal spring is the upward welling of ground waters along a fault zone that blocks the normal south-southeast flow in a region of above-normal heat flow.

GEOTHERMOMETER ANALYSES: Chalcedony-silica geothermometer yielded a temperature estimate of $67^{\circ} \mathrm{C}$ to $72^{\circ} \mathrm{C}$ (Barrett and Pearl, 1978). Chalcedony mixing model analysis yields a subsurface temperature estimate of $79^{\circ} \mathrm{C}$ to $93^{\circ} \mathrm{C}$ with a cold water fraction of 30 to 43 percent of the total flow. The cold-water data used in this calculation (T: $11^{\circ} \mathrm{C}, \mathrm{SiO}_{2}: 19 \mathrm{mg} / 1$ ) may not reflect the actual ground water conditions at depth. Klein (1976) states that ground water in the San Luis Valley area has an exceedingly high silica content. If this is true and the assumed silica in the ground water is below the actual concentration, then the subsurface temperature and cold-water-fraction estimates are too high. The $\mathrm{Na}-\mathrm{K}$ and $\mathrm{Na}-\mathrm{K}-\mathrm{Ca}$ geothermometers yield subsurface temperature estimates of $195^{\circ} \mathrm{C}$ to $206^{\circ} \mathrm{C}$ and $87^{\circ} \mathrm{C}$ to $92^{\circ} \mathrm{C}$, respectively. The $\mathrm{Na}-\mathrm{K}$ geothermometer estimate is too high because one of the assumptions of the model were violated. Large travertine mounds and calcium carbonate-depositing springs suggest that both the $\mathrm{Na}-\mathrm{K}$ and $\mathrm{Na}-\mathrm{K}-\mathrm{Ca}$ geothermometer estimates are too high.

Conclusion: The mixing model and the silica and Na-K-Ca geothermometers predict that the temperature at depth in this area is between $70^{\circ} \mathrm{C}$ and $90^{\circ} \mathrm{C}(\mathrm{Table} 3)$.

RESOURCE ASSESSMENT: Romero \& Fawcett (1978) have shown the presence of a resistivity low extending northwest up the valley from the general area of Mineral Hot Springs. They have also shown that the valley floor northwest' of the hot spring has been cut by numerous faults. 


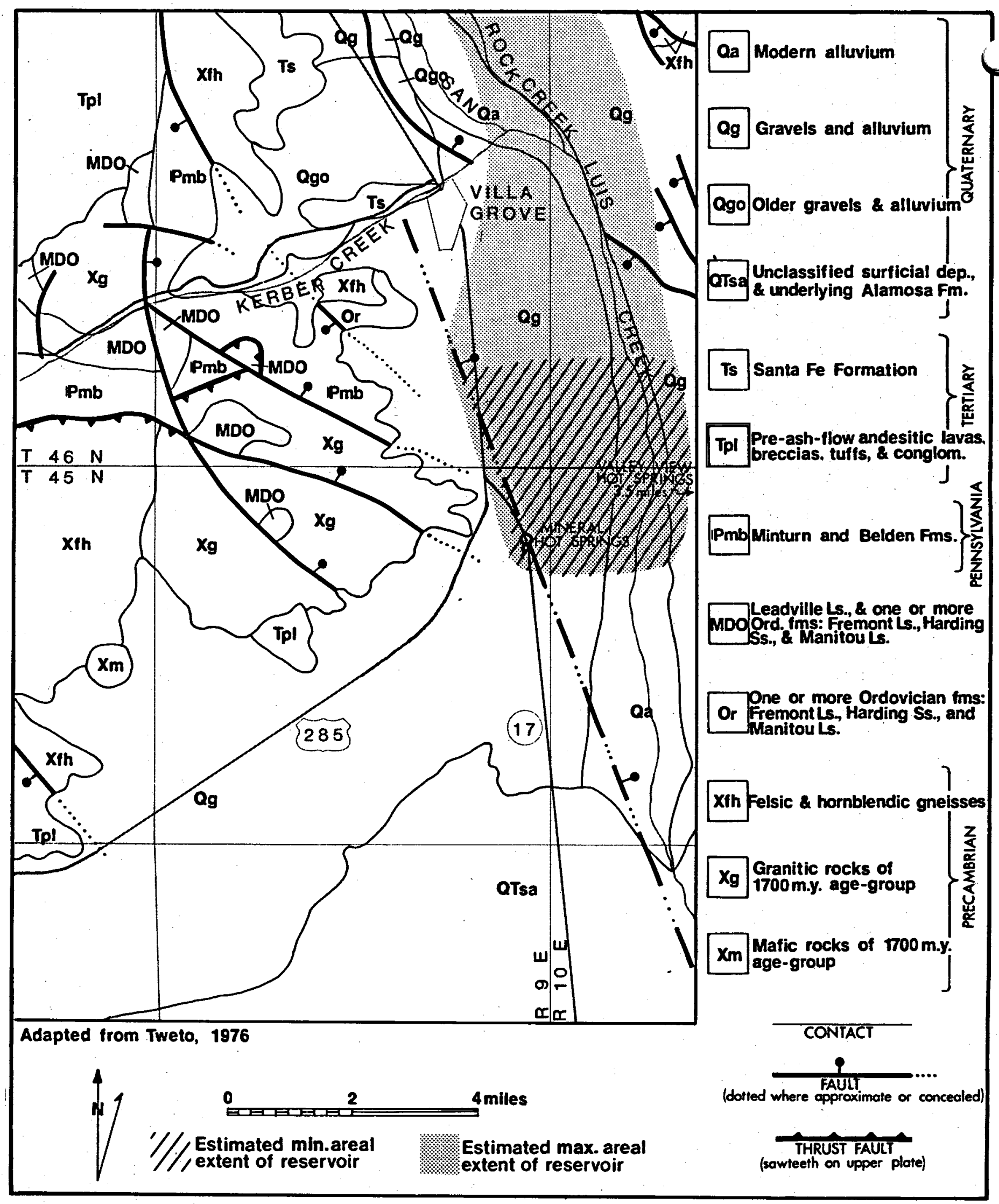

Figure 29.--Map of geologic conditions surrounding Mineral Hot Springs and estimated areal extent of the geothermal reservoir. 
In making this assessment, using Romero \& cetts (1978) data, the author made two estimates the heat contained in the system. The more conservative estimate restricted the reservoir to an area of approximately $10.1 \mathrm{sq} \mathrm{mi}$ north of the spring. This area was calculated to contain .9492 $Q$ 's of energy at an average maximum temperature of $70^{\circ} \mathrm{C}$. The other estimate extended the reservoir up the valley for a distance of $32 \mathrm{sq} \mathrm{mi}$, encompassing the resistivity low of Romero \& Fawcett (1978). This area was calculated to contain 3.007 Q's of energy (Table 2). The difference in temperature estimates can be explained by the methods presented by the estimates of Romero \& Fawcett (1978) and this report. Romero \& Fawcett (1978), in calculating the temperature of the reservoir, used the average of all four geothermal temperatures $\left(155^{\circ} \mathrm{C}\right.$ ) presented by Barrett \& Pearl. Barrett \& Pearl (1978) stated that the most likely temperature of this reservoir is $70-90^{\circ} \mathrm{C}$. The author in his calculation used a reservoir temperature of $70^{\circ} \mathrm{C}$. Whereas, Romero \& Fawcett (1978) assumed that the reservoir had a thickness of $6,821 \mathrm{ft}$, the author assumed that the reservoir only had a thickness of $1,000 \mathrm{ft}$. 


\title{
\#32 VALLEY VIEW HOT SPRINGS
}

\author{
(ORIENT HOT SPRINGS)
}

LOCATION: Latitude: $38^{\circ} 11^{\prime} 32^{\prime \prime N}$.; Longitude: $105^{\circ} 48^{1} 49^{\prime} \mathrm{W} ;$ T. 46 N., R. $10 \mathrm{E}$ Sec. $36 \mathrm{db}$, N.M.P.M.; Saguache County; Valley View Hot Springs 7. 1/2-minute topographic quadrangle map.

GENERAL: The Valley View Hot Springs, also known as the Orient Hot Springs, are located on the east side of the San Luis Valley approximately $12 \mathrm{miles}$ southeast of Villa Grove. The area around these thermal springs is relatively undeveloped, with the waters being used for bathing purposes by those camping in the area.

The springs are found in two groups-a lower group consisting of three springs, and an upper group of one spring. Waters from the largest spring in the lower group were once piped to a large swimming pool. After this pool collapsed in 1974 or 1975, a crude dirt-embankment swimming pool was constructed over Spring A, Spring B, in the lower group and located approximately 50 yd south of $A$, is a small rock-ringed pool. Spring $C$ is located several yards south of $B$ on a hillside.

Spring $D$, the upper spring, is several hundred $f t$ in elevation above Spring $A$ and is reached by a 0.5-mile walk along a well-marked trail leading southeast from Spring $A$.

\section{GEOLOGY AND HYDROLOGY:}

Spring A: Temperature of this spring varied throughout the year's time from $35^{\circ} \mathrm{C}$ to $37^{\circ} \mathrm{C}$. The discharge of the spring was estimated at $60 \mathrm{gpm}$. The total dissolved solids in the water are 234 $\mathrm{mg} / 1$ to $252 \mathrm{mg} / \mathrm{l}$. The waters are a calcium bicarbonate-sulfate type.

Spring $\mathrm{B}$ : This spring has a temperature of $32^{\circ} \mathrm{C}$ and the discharge was not determined. The total dissolved solids in the water are $234 \mathrm{mg} / 1$, and the waters are a calcium bicarbonate type.

Spring C: Not sampled.

Spring D: The temperature of this spring varied throughout the year from $34^{\circ} \mathrm{C}$ to $36^{\circ} \mathrm{C}$. The discharge also varied from 75 to $120 \mathrm{gpm}$. The total dissolved solids in the water varied from 223 $\mathrm{mg} / 1$ to $247 \mathrm{mg} / 1$. The waters are a calcium-bicarbonate type.

The waters are assocjated with the Valley View Fault zone which traverses the east side of the valley in this location (Fig. 30). The bedrock of the area is the Pennsylvanian Minturn and Belden Formations. As shown on Figure 30, these formations are truncated at the Valley View Springs by the Valley View Fault zone along the west side of the Sangre de Cristo Range.

Recent work by Romero and Fawcett (1978) has showed that the bedrock floor of the valley here is extensively cut by high-angle normal faults, one of which is the Valley View Fault. Reiter (1975) showed the San Luis Valley to have a heat flow in excess of 2.0 heat flow units. Recharge to these springs is probably normal ground waters of the valley that enter the fault zone and then circulate deeply.

GEOTHERMOMETER ANALYSES: Analys is showed that chalcedony controls the silica content of the hot springs. The chalcedony-silica geothermometer gave an estimated subsurface temperature of $25^{\circ} \mathrm{C}$ to $34^{\circ} \mathrm{C}$ (Barrett and Pearl, 1978) (Table 3). Although this estimate is below the surface temperature of the springs $\left(34^{\circ} \mathrm{C}-37^{\circ} \mathrm{C}\right)$ it is within the margin of error inherent in the geothermometer technique. Chalcedony mixing model analysis yields a subsurface temperature estimate of $29^{\circ} \mathrm{C}$ to $37^{\circ} \mathrm{C}$, with a cold water fraction of 4 to 33 percent of the spring flow (Table 3 ). The cold-water data used in these calculations (Temp.: $6^{\circ} \mathrm{C} ; \mathrm{SiO}_{2}: 15$ $\mathrm{mg} / 1$ may not reflect the actual ground water conditions at depth. Klein (1976) states that ground waters in the San Luis Valley area have exceedingly high silica content. If the assumed silica content of the cold ground waters is below the actual concentration, then the subsurface temperature and cold water-fraction estimates will be too high.

The $\mathrm{Na}-\mathrm{K}$ and $\mathrm{Na}-\mathrm{K}-\mathrm{Ca}$ geothermometers yield subsurface temperature estimates of $338^{\circ} \mathrm{C}$ to $389^{\circ} \mathrm{C}$ and $10^{\circ} \mathrm{C}$ to $16^{\circ} \mathrm{C}$, respectively. The $\mathrm{Na}-\mathrm{K}-\mathrm{Ca}$ geothermometer estimate is obviously incorrect since it is below the surface temperature of the warm springs. This result may be due to the excessive solution of calcium carbonate by the thermal waters during ascent through numerous caliche zones recently discovered by Romero and Fawcett, 1978).

Conclusion: The high flow rate $(250 \mathrm{gpm})$ and the excellent agreement between the theoretical chalcedony-induced solubility and the silica content of the springs suggest that the temperature at depth in this area is not much greater than the surface temperature. Therefore, the temperature at depth in this area is probably between $40^{\circ} \mathrm{C}$ and $50^{\circ} \mathrm{C}$ (Table 3 ).

RESOURCE ASSESSMENT: In assessing the possible areal extent of this reservoir, the author felt that it was restricted to the Valley View Fault zone (Fig. 30) and only had an areal extent of approximately $1 \mathrm{sq} \mathrm{mi}$. It was estimated that this reservoir is $1,000 \mathrm{ft}$ thick, has a maximum temperature of $50^{\circ} \mathrm{C}$, and contains $.0564 \mathrm{Q}^{\prime} \mathrm{s}$ of heat energy.

Romero and Fawcett (1978), using the same criteria as they used for Mineral. Hot Sprinc calculated that this area contains 265.5 Q's heat energy. 


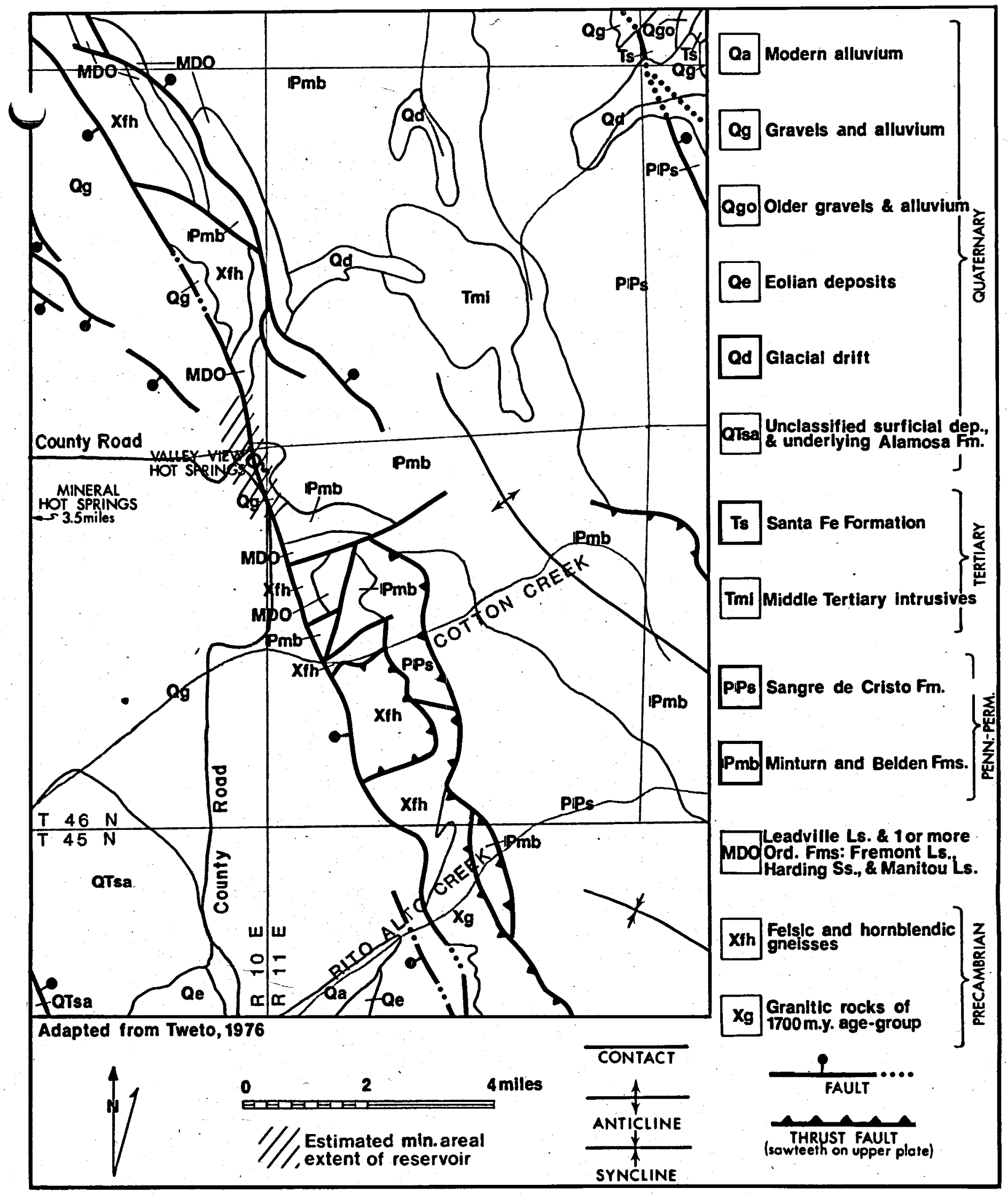

Figure 30.--Valley View Hot Springs area, geology and estimated extent of the geothermal reservoir. 


\section{\#33 SHAWS WARM SPRING}

LOCATION: Latitude: $37^{\circ} 45^{\prime} 01^{\prime N}$.; Longitude: $106^{\circ} 19^{\prime} 01$ "W.; T. 41 N., R. 6 E., Sec. $33 \mathrm{dd}$, N.M.P.M.; Saguache County; Twins Mnts. SE 7 1/2-minute topographic quadrangle map.

GENERAL: This spring is located approximately 6 miles north of Del Norte. The waters are used in a private swimming pool.

GEOLOGY AND HYDROLOGY: Temperature: $30^{\circ} \mathrm{C}$; Discharge: 34 to $50 \mathrm{gpm}$; Total dissolved solids range from 398 to $424 \mathrm{mg} / 1$; Water is a sodium-bicarbonate type.

This spring is located on the west side of the San Luis Valley and the Rio Grande Rift zone. As shown on the accompanying geologic map (Fig. 31), the bedrock of the area is a complex assemblage of volcanic rocks related to the Summer Coon Volcano and other centers of volcanic activity in the area. All the rocks erupted from the Summer Coon Volcano have been included in the Conejos Formation by Lipman and others (1970).

The geology of the region has been described in detail by Lipman (1968) and Mertzman (1971). As described by these two authors, the spring is located well down on the lower southeast flank of the Summer Coon Volcano.

The bedrock of the area is an assemblage of volcanic rocks, tuffaceous sandstones, and conglomerates (Fig. 31). Mertzman (1971) noted that the Summer Coon Volcano was active 31.1 to 34.7 million years ago (late $\mathrm{Paleocene}$ ) and that the volcano became extinct by the time the Rio Grande depression began in early Miocene time.

One fault exists approximately $0.5 \mathrm{mile}$ to the northeast of the spring site, but probably has not affected the occurrence of the spring. It is believed that the waters move down dip through permeable interflow units until they emerge at this site. Recharge probably occurs in the higher ground to the west, and the heat source is probably residual Tertiary volcanic activity in the area.

GEOTHERMOMETER ANALYSES: Barrett and Pearl (1978) showed that amorphous silica may control the silica content of the warm spring. The amorphous silica geothermometer subsurface temperature estimate is $2^{\circ} \mathrm{C}$ to $17^{\circ} \mathrm{C}$, which is well below the surface temperature of the warm spring $\left(30^{\circ} \mathrm{C}\right)$. This low temperature estimate may be caused by mixing of ascending thermal water and dilute ground water or silica precipitation at depth.

Amorphous silica mixing model analysis yields a subsurface temperature estimate of $26^{\circ} \mathrm{C}$ to $28^{\circ} \mathrm{C}$ with a cold-water fraction of 19 to 32 percent of the spring flow (Table 3 ).

The $\mathrm{Na}-\mathrm{K}$ and $\mathrm{Na}-\mathrm{K}-\mathrm{Ca}$ geothermometers yield subsurface temperature estimates of $98^{\circ} \mathrm{C}$ to $101^{\circ} \mathrm{C}$ and $83^{\circ} \mathrm{C}$ to $104^{\circ} \mathrm{C}$, respectively. These results are unreliable because the low discharge (45 gpm) and surface temperature $\left(30^{\circ} \mathrm{C}\right)$ of this spring are well below the minimum conditions specified for the application of these geothermometers.

Conclusion: Geothermometers should be used with caution when applied to Shaw's Warm Spring because most of the assumptions inherent in their use are violated. From review of all data it is believed that the most likely subsurface temperature in this area is between $30^{\circ} \mathrm{C}$ and $60^{\circ} \mathrm{C}$ (Table 3 ).

RESOURCE ASSESSMENT: Barrett \& Pearl (1978) postulated that the occurrence of this spring was due to a down dip flow of waters through permeable inter-volcanic units. The thickness of these units is unknown; therefore, a thickness of $500 \mathrm{ft}$ was assigned. It was estimated that the reservoir is a sedimentary reservoir and encompasses an area of approximately $0.63 \mathrm{sq} \mathrm{mi}$ and has an average maximum temperature of $45^{\circ} \mathrm{C}$. Calculations show that a reservoir of this size could contain $0.0148 Q^{\prime} s$ of heat energy (Table 2). 


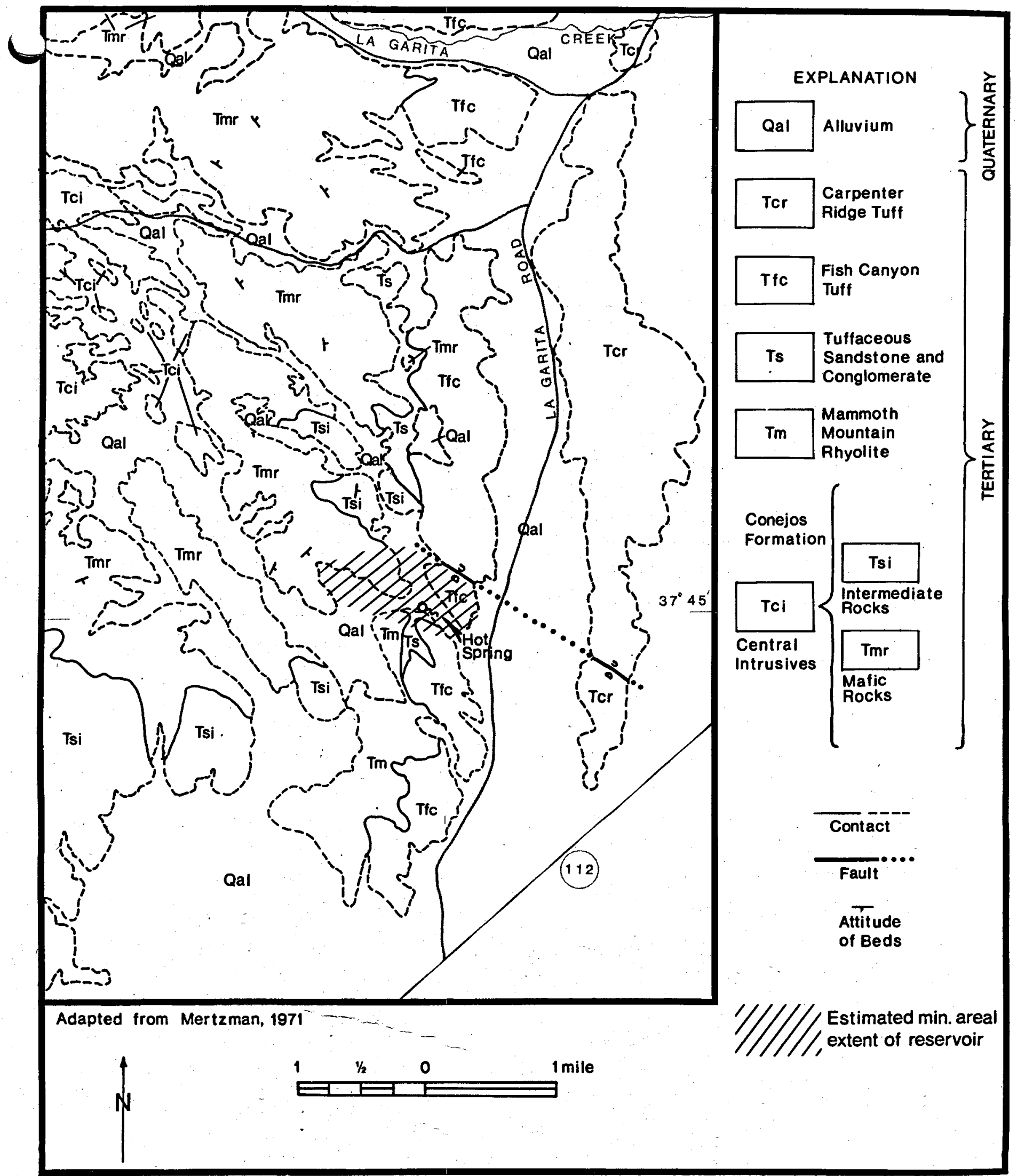

Figure 3i.--Geology and estimated areal extent of the geothermal reservoir, Shaws Warm Spring. 


\section{\#34 SAND DUNES SWIMMING POOL HOT WATER WELl}

LOCATION: Latitude: $37^{\circ} 46^{\prime} 42^{\prime \prime N}$.; Longitude: $105^{\circ} 51^{\prime} 20$ "W.; T. 41 N., R. 10 E., Sec. 27 aa, N.M.P.M.; Al amosa County; Deadman Camp 7 1/2-minute topographic quadrangle map.

GENERAL: This 4,400-ft-deep well is located 3 miles northeast of Hooper in the San Luis Valley. of the two wells present, the north well is hot and the south well is cold. The hot well was sampled at the discharge pipe by the pump.

GEOLOGY AND HYDROLOGY: The temperature of the thermal waters was $44^{\circ} \mathrm{C}$, with a total dissolved solids of $334 \mathrm{mg} / 1$. The waters are a sodium bicarbonate type with a high silica content.

Chapin (1971), Emery (1971), Emery and others (1971), and Stoughton.(1977) have presented detailed discussions of the geology and hydrology of the San Luis Valley and the Rio Grande Rift zone. As shown by Gacia and Karig (1966) and Stoughton (1977) this well is approximately located over the deepest part of the San Luis Valley. Gacia and Karig (1966) showed that the deepest part of the basin contained up to $30,000 \mathrm{ft}$ of valley-fill sediments. Later work by Stoughton (1977) has revised this figure to a maximum of approximately $20,000 \mathrm{ft}$ of valley fill sediments. A deep oil well test was drilled in 1974 in T. 40 N., R. 12 E., Sec. 32 , bd, N.M.P.M. by Mapco and Amoco. This well was drilied to a depth of 9,480 $\mathrm{ft}$ and had a bottom-hole temperature of $128^{\circ} \mathrm{C}$. The geothermal gradient in the well was $38.8^{\circ} \mathrm{C} / \mathrm{km}$ $\left(3.1^{\circ} \mathrm{F} / 100 \mathrm{ft}\right)$. Reiter $(1975)$ has determined that this part of the San Luis Valley has a heat flow of 2.4 heat flow units.

From analysis of all published data it is believed that these thermal waters occur as a result of normal movement of ground water from west to east in the San Luis Valley in an area of above-normal heat flow. While no faults have been mapped in the vicinity, it is believed that the waters are fault controlled.

GEOTHERMOMETER ANALYSES: When analyzing the estimated subsurface temperatures of this system, Barrett and Pearl (1978) noted that the geothermometer models yield questionable results because most of the assumptions inherent in their use are violated. However, they did calculate the subsurface temperatures. Their results were: Amorphous-silica, $26^{\circ} \mathrm{C}$.: Amorphous-silica mixing model, $39^{\circ} \mathrm{C}$ with a cold-water fraction of 19 percent; $\mathrm{Na}-\mathrm{K}$ and $\mathrm{Na}-\mathrm{K}-\mathrm{Ca}, 205^{\circ} \mathrm{C}$ and $187^{\circ} \mathrm{C}$, respectively (Table 3 ).

Conclusion: The complex geochemistry of this well does not allow an accurate estimation of the subsurface temperature (Barrett and Pearl, 1978).

RESOURCE ASSESSMENT: Al though there is uncertainty regarding the occurrence of this reservoir, the author estimated that it this is a sedimentary reservoir that encompasses an area of $1.5 \mathrm{sq} \mathrm{mi}$ around the well. With a maximum temperature of $75^{\circ} \mathrm{C}$ it could contain 0.1551 Q's of heat energy (Table 2). 


\section{\#35 SPLASHLAND HOT WATER WELL}

LOCATION: Latitude: $37^{\circ} 29^{\prime} 19^{\prime \prime} \mathrm{N} . ;$ Longitude: $105^{\circ} 51^{\prime} 27$ "W.; T. 38 N., R. 10 E., Sec. $34 \mathrm{dd}$, N.M.P.M.; Al amosa County; $A 1$ amosa East 7 1/2-minute topographic quadrangle map.

GENERAL: This 2,000-ft-deep well is located approximately 200 yds southwest of the Splashland Swimming Pool, 1 mile north of Alamosa on State Highway 17. The waters are used for recreational purposes in the swimming pool.

GEOLOGY AND HYOROLOGY: The waters have a temperature of $40^{\circ} \mathrm{C}$ and contain $311 \mathrm{mg} / 1$ of dissolved elemental mineral matter. The waters are a sodium bicarbonate type. The waters are associated with the valley-fill sediments of the San Luis Valley. Recharge occurs along the west side of the valley with the waters migrating to the east in the subsurface in an area of above-normal geothermal gradients (Reiter, 1975).

GEOTHERMOMETER ANALYSES: Barrett and Pearl (1978) determined that geothermometer analys is yielded questionable results when applied to this thermal well because most of the assumptions inherent in their use are violated. They did, however, solve the various geothermometer models. The amorphous-silica geothermometer model yielded a subsurface temperature estimate of $22^{\circ} \mathrm{C}$ (Table 3 ). The Amorphous Silica Mixing Model analys is yields a subsurface temperature estimate of $35^{\circ} \mathrm{C}$ with a cold water fraction of 23 percent of the spring flow (Table 3). The cold water data used in these calculations ( $\mathrm{T}: 6^{\circ} \mathrm{C}, \mathrm{SiO}_{2}: 25 \mathrm{mg} / 1$ ) may not reflect the actual ground-water conditions at depth. Klein (1976) states that ground water in the San Luis Valley has an exceedingly high silica content. If the assumed silica content of the cold ground water is below the actual concentration, then the subsurface temperature and cold water-fraction estimates are too high. The Na-K and $\mathrm{Na}-\mathrm{K}-\mathrm{Ca}$ geothermometers yield subsurface temperature estimates of $221^{\circ} \mathrm{C}$ and $197^{\circ} \mathrm{C}$, respectively (Table 3 ).

Conclusion: Geothermometer models yield questionable results when applied to this thermal well because most of the assumptions inherent in their use are violated. From review of all data it appears that the subsurface temperature in this area is probably between $40^{\circ} \mathrm{C}$ and $100^{\circ} \mathrm{C}$ (Table 3 ).

RESOURCE ASSESSMENT: These thermal waters are thought to be contained in the valley fill sediments (Barrett \& Pearl, 1978). As the subsurface geologic conditions are unknown, for assessment of the resource it was assumed that the reservoir could encompass an area of $1.5 \mathrm{sq} \mathrm{mi}$. Calculations show that it could contain 0.1551 Q's of heat energy (Table 2). 


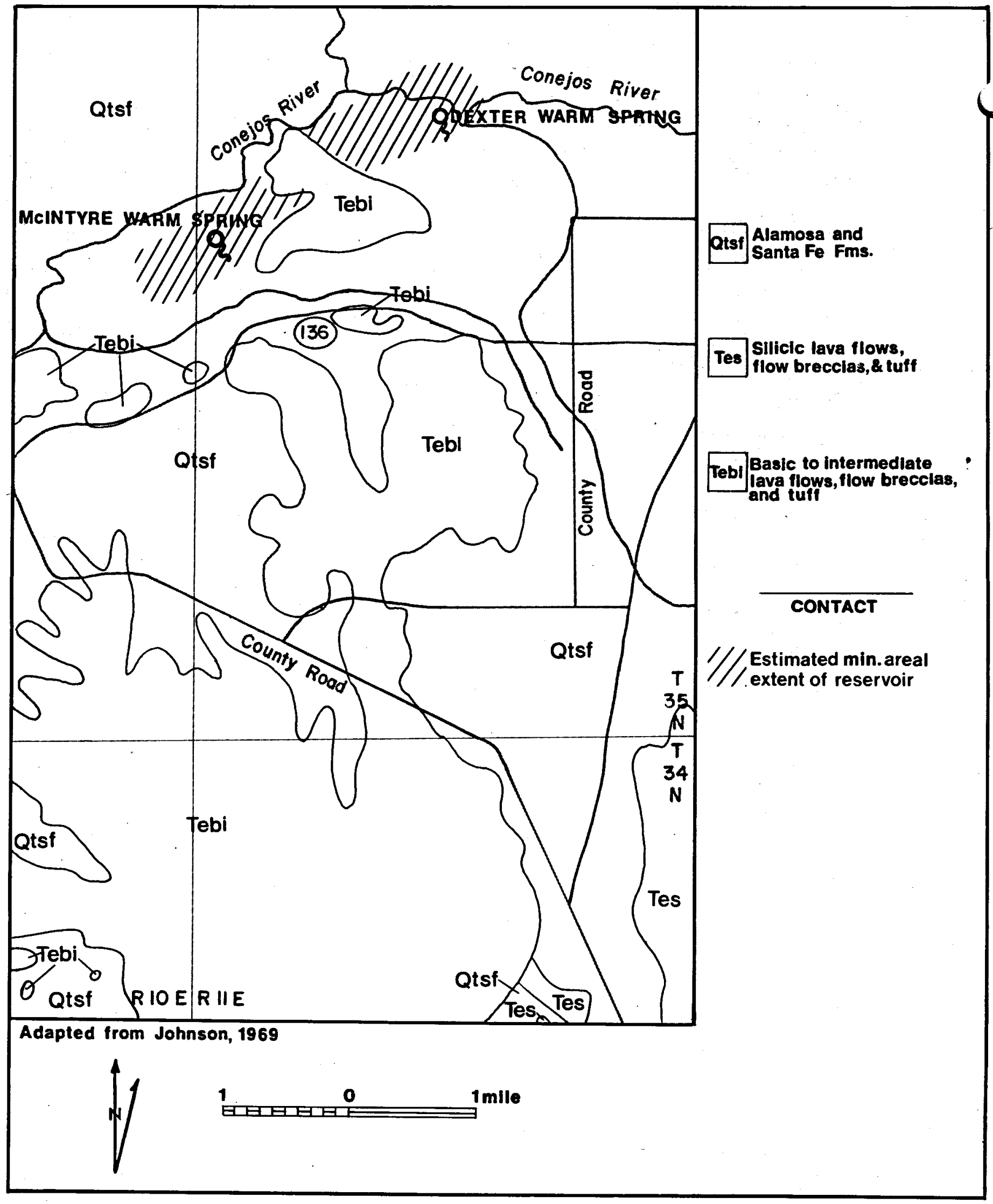

Figure 32.--Map showing estimated areal extent of the Dexter and McIntyre Warm Springs geothermal reservoir and surrounding geologic conditions. 


\section{DEXTER AND MCINTYRE WARM SPRINGS}

Located on the north side of the San Luis Hills in the southern end of the San Luis Valley are two springs, Dexter and McIntytre, whose occurrence and characteristics are nearly identical. As these springs appear so nearly identical, they will be discussed together.

\section{\#36 DEXTER WARM SPRING}

Location: Latitude: $37^{\circ} 17^{\prime} 41^{\mathrm{N}} \mathrm{N} . ;$; Longitude: $105^{\circ} 47^{\circ} 05^{\prime \prime}$. $_{\text {; }}$ T. 35 N., R. 11 E., Sec. 8 ada; Conejos County; Pikes Stockade 7 1/2-minute topographic quadrangle map.

GENERAL: This group of several unused springs and seeps is located in a marshy area on the north side of the San Luis Hills and on the south side of the
Conejos River. The springs are reached by going east from Sanford on Colorado Highway 142 for 7.1 miles to a dirt road. Turn north on this road and go approximately 1.75 miles to the springs.

The springs have a temperature of $20^{\circ} \mathrm{C}$ with a combined discharge of just over $5 \mathrm{gpm}$. The waters contain $195 \mathrm{mg} / 1$ of dissolved solids and are a sodium-bicarbonate type.

\section{\#37 MdNTYRE WARM SPRING}

LOCATION: Latitude: $\quad 37^{\circ} 16^{\prime} 48^{\prime \prime N}$.; Longitude: 105049 $07^{\circ}$ W.; T. 35 N., R. 11 E., Sec. 18 bcb, N.M.P.M.; Conejos County; P.ikes Stockade 7 1/2-minute topographic quadrangle map.

GENERAL: These 10 to 15 unused springs are located on the south bank of the Conejos River south of Alamosa in the San Luis Valley. Access is via a paved county road for 5.3 miles east from Sanford, Colorado, then north and east on a dirt trail for approximately 1 mile.
While the temperature of these springs (10 to $14^{\circ} \mathrm{C}$ ) is below the minimum temperature used during this investigation, these springs were sampled and measured because of their association with the nearby Dexter Warm Springs. Due to the amount of surface water flowing through the area, it was not possible to measure the discharge of the springs, but it appears to be large. The waters contain 165 $\mathrm{mg} / \mathrm{l}$ of dissolved solids and are a calcium-bicarbonate type.
GEOLOGY AND HYDROLOGY OF DEXTER AND MCINTYRE WARM SPRINGS: As the geological and hydrogeological conditions surrounding each spring are nearly identical, they will be discussed together. The springs are located on the north side of the San Luis Hills and emerge from sediments of the Santa Fe Group (Fig. 32). The San Luis Hills consist of a series of middle to late Tertiary lava flows that rise prominently above the flat surface of the San Luis Valley. The geology of this area has been described in detail by Burroughs (1971). While no faults are shown on the geologic map (Fig. 32), it appears from Burroughs' description that the springs are probably associated with faulting on the north side of the hills.

The origin of the heat for the thermal waters is in doubt but appears to be related to the Pliocene volcanic activity that took place in this area (Burroughs, 1971). Reiter (1975) has mapped the San Luis Valley as having heat flow above 2.5 heat flow units. The origin of the springs is probably due to deep circulation of ground waters in the San Luis Valley ascending through fault - res in an area of above-normal geothermal dients.
GEOTHERMOMETER ANALYSES FOR DEXTER AND MCINTYRE WARM SPRINGS: The silica content of these springs does not approach the solubilities of amorphous silica, chalcedony, cristobalite or quartz. Therefore, application of any of these silica geothermometers will yield unreliable results. The amorphous-silica mixing model yields subsurface temperature estimates of $15^{\circ} \mathrm{C}$ to $19^{\circ} \mathrm{C}$, with cold water fractions of 33 to 36 percent of the spring flow. The $\mathrm{Na}-\mathrm{K}$ and $\mathrm{Na}-\mathrm{K}-\mathrm{Ca}$ geothermometers yield subsurface temperature estimates of $278^{\circ} \mathrm{C}$ to $333^{\circ} \mathrm{C}$ and $50^{\circ} \mathrm{C}$ to $91^{\circ} \mathrm{C}$, respectively. The $\mathrm{Na}-\mathrm{K}$ geothermometer results are too high because one of the assumptions of the model is violated. The low surface temperature of the warm springs and the lack of substantiation of such high temperatures at depth by the other geothermometers suggest that both the $\mathrm{Na}-\mathrm{K}$ and $\mathrm{Na}-\mathrm{K}-\mathrm{Ca}$ results are unreliable.

Conclusion: Geothermometer models must be used with caution when appliad to McIntyre and Dexter warm springs because most of the assumptions inherent in their use are violated. Any geothermometer est imate for this area is unreliable at best. However, it appears that the temperature at depth is probably between $20^{\circ} \mathrm{C}$ and $50^{\circ} \mathrm{C}$ (Table 3). 
RESOURCE ASSESSMENT: No definitive work has been published on the subsurface geologic conditions of the reservoir (Barrett \& Pearl, 1978). Therefore, the reservoir's areal extent was estimated to extended in a NE-SW direction along the front of the San Luis Hills and encompassed an area of 1 sq mi. Estimates show that the reservoir contaih .0339 Q's of heat energy at an maximum temperature of $35^{\circ} \mathrm{C}$ (Table 2). 


\section{\#38 STINKING SPRINGS}

LOCATION: Latitude: $37^{\circ} 02^{\prime} 05^{\prime \prime N}$.; Longitude: $106^{\circ} 48^{\prime} 25$ "W.; T. 32 N., R. 1 E., Sec. 2 dd, N.M.P.M.; Archuleta County; Chromo 15-minute topographic quadrangle map.

GENERAL: These unused springs are located approximately 2 miles east of Chromo. Although marshy areas exist near these springs, only one with any distinct flow was located approximately $100 \mathrm{yd}$ south of the road.

GEOLOGY AND HYDROLOGY: The spring had a temperature of $27^{\circ} \mathrm{C}$ with a discharge of $24 \mathrm{gpm}$. The total dissolved mineral matter solids contained in the waters are $899 \mathrm{mg} / 1$, and the waters area a calcium-sulfate type.

As shown on Figure 33 , the springs are located on the crest of the Chromo Anticline on the trace of a small northwest trending fault. The bedrock of the area, Mancos Shale, dips to the southwest off of the Continental Divide, which bounds the basin on the east side. It is believed that recharge to this spring occurs along the eastern flank of the San Juan Basin where the waters move downdip until they intersect a fault. They then migrate upward along the fault to the surface. Heating of the waters occurs because this area has above normal heat flow (Reiter, 1975).

GEOTHERMOMETER ANALYSES: Using the following geothermometer models the following subsurface temperatures were calculated (Barrett and Pearl, 1978): Chalcedony-silica geothermometer, $39^{\circ} \mathrm{C}$, Chalcedony silica mixing model $59^{\circ} \mathrm{C}$ with a cold water fraction of 61 percent, Na-K geothermometer, $39^{\circ} \mathrm{C}$, and the $\mathrm{Na}-\mathrm{K}-\mathrm{Ca}$ geothermometer, $41^{\circ} \mathrm{C}$. The $\mathrm{Na}-\mathrm{K}$ estimate is too high because one of the requirements of the model was violated (Barrett and Pear1, 1978).
Conclusion: Geothermometer models must be used with caution when applied to Stinking Springs because most of the assumptions inherent in their use are violated. Moreover, samples of the thermal water had to be taken from a large, quiescent pool where evaporative concentration of silica and other re-equilibration reactions may have occurred.

In light of the excellent agreement between the mixing model and the silica and $\mathrm{Na}-\mathrm{K}-\mathrm{Ca}$ geothermometers the subsurface temperature in this area is probably between $40^{\circ} \mathrm{C}$ and $60^{\circ} \mathrm{C}$ (Table 3 ).

RESOURCE ASSESSMENT OF STINKING SPRINGS AND DUTCH CROWLEY ARTESIAN WELL: Even though Barrett \& PearT (1978) described the origin of Stinking Springs as due to faulting for resource assessment purposes, the author considers the reservoir to be a sedimentary reservoir. This is due to the fact that there are no faults mapped in the vicinity of this spring (Fig. 33). This does not preclude the possibility that the waters could be moving up a fault and into a sedimentary formation. For the same reason it was assumed that the Dutch Crowley Artesian well is drawing its water from a sedimentary reservoir.

Two estimates of the reservoir areal extent were made. In one case it was assumed that the reservoir encompassed some $3.66 \mathrm{sq} \mathrm{mi}$ along the crest of the anticline and included both thermal water orifices. In the other case it was assumed that the reservoir was restricted to a net area of $1.52 \mathrm{sq} \mathrm{mi}$ around both thermal water orifices ( $\mathrm{Fig}$. 33).

The amount of energy estimated to be contained in the system ranges from .0257 to $.0620 . Q^{\prime} s$ at an average maximum temperature of $65^{\circ} \mathrm{C}$ (Table 2). 


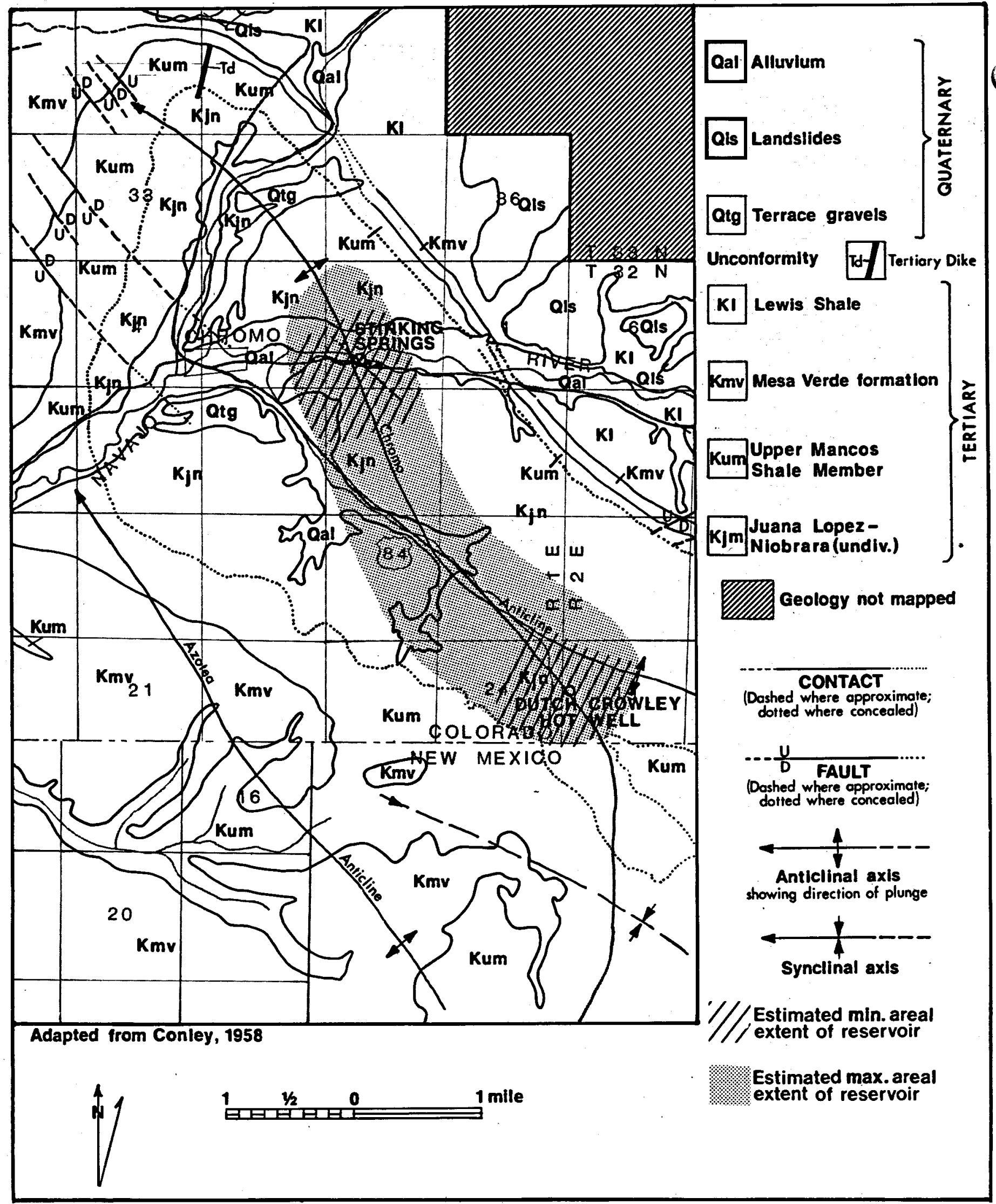

Figure 33.--Map of Stinking Springs and Dutch Crowley Artesian Well region showing geology and estimated areal extent of the geothermal reservoirs. 


\section{\#39 DUTCH CROWLEY ARTESIAN WELL}

LOCATION: Latitude: $37^{\circ} 00^{\prime} 01^{\prime \prime N} . ; \quad$ Longitude: $106^{\circ} 47^{\circ} 03^{\prime \prime W}$.; T. 32 N.; R. 2 E., Sec. $18 \mathrm{bbb}$, N.M.P.M.; Archuleta County; Chromo 15-minute topographic quadrangle map.

GENERAL: This artesian well, which is an old oil well test hole $1,725 \mathrm{ft}$ deep, is located south of Chromo, Colorado, on the Colorado-New Mexico border. Access is via U.S. 84 south from Pagosa Springs to two miles south of Chromo where a dirt trail leads to the east. Turn left on this trail and proceed approximately 1.3 miles until the trail turns south. The well is 0.2 mile south of this turn and approximately $1,000 \mathrm{ft}$ east of the road. The well is used for irrigation purposes.

GEOLOGY AND HYDROLOGY: The waters that flow from the well with a temperature of $70^{\circ} \mathrm{C}$ are a sodium bicarbonate type and contain $101 \mathrm{mg} / 1$ of dissolved solids.

As shown of Figure 33 , the well is located on the lower northeast side of the Chromo Anticline. The bedrock of the area is the Juana Lopez Member of the Mancos Shale, and other than minor faulting mapped less than one mile east of the well, no other major structural features have been mapped in the vicinity.

The general dip of the formations in this part of the San Juan basin is to the southwest off the Continental Divide, which bounds the basin on the east. Due to the depth of the wel1, 1,725 ft, it is believed that the waters come from the underlying Dakota Sandstone. Recharge occurs along the flanks of the Continental. Divide where the waters move down dip to the southwest in an area where the heat flow is between 2.0 and $2.5 \mathrm{H} . \mathrm{F} . \mathrm{U}$. (Reiter, 1975).

GEOTHERMOMETER ANALYSES: Silica solubility and temperature relationships suggest that temperature-dependent equilibration between the thermal water and chalcedony may control the silica content of the artesian well. Therefore, the chalcedony-silica geothermometer yields the most reliable temperature estimate.

The chalcedony-silica geothermometer estimate of subsurface temperature is $63^{\circ} \mathrm{C}$ (Table 3 ). Although this estimate is below the surface temperature of the artesian water $\left(70^{\circ} \mathrm{C}\right)$, it is within the margin of error inherent in the geothermometer technique.

Since temperature-dependent equilibration between the thermal water and chalcedony apparently controls the silica content of the artesian well, the chalcedony mixing model is applicable. Mixing model analysis yields a subsurface temperature estimate of $65^{\circ} \mathrm{C}$ with a cold water fraction of 7 percent of the artesian flow (Table 3 ).

The mixing model should predict a cold-water fraction of 0 percent because of very little opportunity for shallow ground water perculation into a $1,741 \mathrm{ft}$ deep cased well. In addition, the subsurface temperature estimate should equal or exceed the surface temperature of the artesian water $\left(70^{\circ} \mathrm{C}\right)$.

Based on the expected analytical precision, the silica content of this artesian well (41 $\mathrm{mg} / 1)$ should vary from 36.9 to $45.1 \mathrm{mg} / 1$ (Table 3 ). If the maximum value of silica $(45.1 \mathrm{mg} / 1)$ is inserted into the mixing model calculation, the results are $70^{\circ} \mathrm{C}$ and 0 percent. Therefore, the apparent discrepancy between the expected and actual mixing model results is probabiy due to analytical error in determining the silica content of the thermal water.

The $\mathrm{Na}-\mathrm{K}$ and $\mathrm{Na}-\mathrm{K}-\mathrm{Ca}$ geothermometers yield questionable results. The $\mathrm{Na-K}$ geothermometer esimate of $271^{\circ} \mathrm{C}$ is too high because one of the basic requirements of the modle is violated. The $\mathrm{Na}-\mathrm{K}-\mathrm{Ca}$ geothermometer estimate of $16^{\circ} \mathrm{C}$ is obviously wrong since it is below the surface temperature of the artesian well. This result may be due to the excessive solution of calcium carbonate by the thermal water during ascent through the anhydrite deposits of the Todilto Limestone.

Conclusion: The rapid flow rate $(75 \mathrm{gpm})$ and the excellent-agreement between the mixing model and silica geothermometer suggests that the subsurface temperature is near the surface temperature of the artesian we11. Therefore, the temperature at depth in this area is probably between $70^{\circ} \mathrm{C}$ and $80^{\circ} \mathrm{C}$ (Table 3).

RESOURCE ASSESSMENT: See Stinking Springs Resource Assessment 


\section{\#40 EOFF ARTESIAN WELL}

LOCATION: Latitude: $37^{\circ} 11^{\prime} 26^{\prime \prime N}$; Longitude: $106^{\circ} 59^{\top} 36^{\prime \prime}$ W.; T. 34 N., R. 1 W.; Sec. 7 cdc, N.M.P.M.; Archuleta County; Chromo 15-minute topographic quadrangle map.

GENERAL: This unused, 2,998-ft-deep oil-well test hole is located south of. Pagosa Springs. Access is viaU.S. Highway 84 south from Pagosa Springs for $5.8 \mathrm{miles}$, then west on a gravel road for $0.5 \mathrm{mile}$ to a farmhouse. The well is $3.5 \mathrm{miles}$ west of the house along Squaw Canyon.

GEOLOGY AND HYDROLOGY: The waters from this well have a temperature of $39^{\circ} \mathrm{C}$ and an estimated discharge of $50 \mathrm{gpm}$. The waters were not sampled for complete analys is of contained mineral matter, but the field measurement of the conductance was 2,500 micromohs, with a $\mathrm{pH}$ of 7.0

This well is located on the east side of the San Juan Basin. The Colorado portion of the basin is bounded on the north and east by the San Juan Mountains and on the south by the Colorado-New Mexico state line. While the central portion of the basin consists of sedimentary formations dipping into the basin, the San Juan Mountains consist of a complex assemblage of varying volcanic rock types. Very little has been published on the geology of the eastern portion of the San Juan Basin. However, while not directly referring to the geologic history or conditions of the San Juan Basin, Lipman (1975) and Steven and Ratte (1960) have discussed in detail the geologic history, especially the volcanic history, of the southeastern San Juan Mountains.

Because this well is approximately $3,000 \mathrm{ft}$ deep, a surface geologic map would not accurately portray the factors controling the occurrence of the thermal waters. Therefore, no geologic map was prepared for this area.
The bedrock of the area is the Cretaceous Mancos Shale. Formations underlying the Mancos Shale from which the thermal waters could possibly come are, in descending order: Dakota Sandstone, Burro Canyon Formation and the Morrison Formation. It is believed that these thermal waters just represent circulation of ground waters in either the Burro Canyon or some of the sandstone units in the Morrison Formation in an area having above-normal geothermal gradients. Reiter (1975) has shown this area to have a heat flow of between 2.0 and 2.5 heat flow units.

GEOTHERMOMETER ANALYSES: Cristobalite-silica geothermometer model yielded a subsurface temperature estimate of $47^{\circ} \mathrm{C}$ (Barrett and Pearl, 1978). Cristobalite mixing model analys is yields a subsurface temperature estimate of $59^{\circ} \mathrm{C}$. with a cold water fraction of 38 percent of the total flow. Barrett and Pearl (1978) determined that the $\mathrm{Na}-\mathrm{K}$ and $\mathrm{Na}-\mathrm{K}-\mathrm{Ca}$ geothermometers yield subsurface temperature estimates of $221^{\circ} \mathrm{C}$ and $56^{\circ} \mathrm{C}$, respectively. The $\mathrm{Na}-\mathrm{K}$ geothermometer est imate is too high because the basic requirement of the model is violated (Fournier and Turesdell, 1973). The $\mathrm{Na}-\mathrm{K}-\mathrm{Ca}$ geothermometer estimate is in good agreement with the mixing model results.

Conclusion: The rapid discharge of this well suggests that the temperature at depth is not much higher than the surface temperature of the thermal water $\left(39^{\circ} \mathrm{C}\right)$. However, the mixing model and the $\mathrm{Na}-\mathrm{K}-\mathrm{Ca}$ geothermometer suggest a temperature of about $60^{\circ} \mathrm{C}$. Therefore, the subsurface temperature in this area is probably between $40^{\circ} \mathrm{C}$ and $60^{\circ} \mathrm{C}$ (Table 3).

RESOURCE ASSESSMENT: As noted above, no geologic map was prepared for this area. It was estimated that the reservoir could have an areal extent of approximately $1.5 \mathrm{sq} \mathrm{mi}$ and contain .0169 Q's of heat energy (Table 2 ). 


\section{\#41 PAGOSA SPRINGS}

LOCATION: Latitude: $37^{\circ} 15^{\prime} 52^{\prime \prime N}$.; Longitude: $.107^{\circ} 00^{\prime} 37^{\prime \prime} W_{\text {. }}$ T. 35 N., R. 2 W.; Sec. $13 \mathrm{~cd}$, N.M.P.M.; Archuleta County; Pagosa Springs 7 1/2-minute topographic quadrangle map.

GENERAL: This group of several springs and wells, collectively known as Pagosa Springs, are located throughout the downtown area of the town by the same name on U.S Highway 160 and 84 , in the southwest part of Colorado. The major spring, Big Spring (Fig. 34), is located across from the downtown area on the south bank of the San Juan River by the Spring Inn Motel. This spring is the second largest spring in the State of Colorado.

At the present time at least five producing wells and several abandoned wells are located throughout the downtown area. Thermal waters are used throughout the city for the following: recreational purposes in the swimming pool at the Spa Mote1; space heating of the courthouse building, the Spring Inn Motel, the Methodist Church, the Texaco and Standard $0 i l$ gas stations west of the courthouse; and for partial space heating of the Rexal.1 Drug store on Main Street, and the Adobe Inn.

GEOLOGY AND HYDROLOGY: Waters from the Big Spring and two wells were sampled and analyzed. Samples were collected from the edge of the Big Spring. This spring had a temperature that ranged throughout the year's time from $54^{\circ} \mathrm{C}$ to $58^{\circ} \mathrm{C}$. The discharge varied from a low of $226 \mathrm{gpm}$ to a high of $265 \mathrm{gpm}$. Due to the diversion of some of the spring water, it was necessary to measure the discharge at several points and then combine them. The main. flow was measured in a ditch approximately $200 \mathrm{ft}$ south of the spring, while other flows were measured down along the river below the motel. The waters contain between 3,040 to $3,310 \mathrm{mg} / 1$ of dissolved mineral matter and are a sodium-sulfate type.

Waters from the Spa Motel's 500-ft-deep well, which were sampled at the wellhead, have a temperature of $53^{\circ} \mathrm{C}$ and contain $3,320 \mathrm{mg} / 1$ of dissolved solids. These waters are a sodium-sulfate type.

The Courthouse well, located behind the courthouse, was sampled at the point of outfall from the building. This well has a discharge of 30 gpm, with a temperature of $56^{\circ} \mathrm{C}$. The waters contain $3,300 \mathrm{mg} / 1$ of dissolved solids and are a sodium-suifate type.

As shown on Fjgure 34 , the bedrock of the area is the Mancos Shale. Although a major fault lies approximately 1.5 mile southwest of the spring, no obvious controlling structural feature for the occurrence of this spring can be seen. Precipitation of the minerals from the waters has fnrmed a large travertine mound around the Big jing. The mineral matter found in the thermal waters is derived from the Mancos Shale. Based on conversations with various well owners, plus interperation of the geologic conditions of the area, it appears that the thermal waters are coming from the Dakota Formation.

GEOTHERMOMETER ANALYSIS: The chalcedony-silica geothermometer yielded an estimated reservoir temperature of $76^{\circ} \mathrm{C}$ to $81^{\circ} \mathrm{C}$ (Barrett and Pearl, 1978). The chalcedony mixing model yields a subsurface temperature estimate of $113^{\circ} \mathrm{C}$ to $134^{\circ} \mathrm{C}$ with a cold water fraction of 54 to 66 percent of the spring flow.

The seasonal fluctuation of the subsurface temperature estimates suggests that the assumed cold-water analys is and percent-mixing est imates do not adequately represent the hydrological conditions at depth. However, no certain conclusions can be made from these estimates because they are within the range of values that could result from normal analytical error.

The $\mathrm{Na}-\mathrm{K}$ and $\mathrm{Na}-\mathrm{K}-\mathrm{Ca}$ geothermometers yield subsurface temperature estimates of $207^{\circ} \mathrm{C}$ to $211^{\circ} \mathrm{C}$ and $191^{\circ} \mathrm{C}$ to $195^{\circ} \mathrm{C}$, respectively (Barrett and Pearl, 1978) (Table 3). Extensive travertine deposits occur throughout this area, and the Big Spring currently deposits travertine along the south bank of the San Juan River. The presence of these deposits indicates that the $\mathrm{Na}-\mathrm{K}$ and the Na-K-Ca geothermometers are too high.

Conclusion: The insignificant variation in surface temperature, mineral content, and geothermometer estimates of these hot springs suggests that they are not substantially affected by seasonal meteorological conditions. The fluctuations of the various geothermometer estimates are well within the range of values that could result from normal analytical error. Consideration of the various geothermometer estimates (Table 3) and the precision of the geothermometers suggests a temperature at depth between $80^{\circ} \mathrm{C}$ and $150^{\circ} \mathrm{C}$ (Table 3).

RESOURCE ASSESSMENT: As noted above, Barrett \& Pearl (1978) stated that no controlling structural feature for this spring could be seen. During the summer of 1978 the Colorado Geological Survey drilled two wells behind the courthouse across the San Juan River from the spring. The first well.was drilled to a depth of 780 .ft before the hole was abandoned because of caving. The second well was drilled to a depth of $1,483 \mathrm{ft}$ and bottomed in Precambrian (?) granite and metamorphic rocks.

In both of these wells, hot waters $\left(56^{\circ} \mathrm{C}\right)$ were encountered in the Mancos Shaie and the Dakota Formation. Below the Dakota aquifer the temperature of the water dropped to $45^{\circ} \mathrm{C}$. While all. the rock units encountered carried at least some water, the hottest waters were restricted to the Dakota and Mancos Formations. The author believes that the Mancos is really a secondary aquifer and that the primary shallow aquifer in 


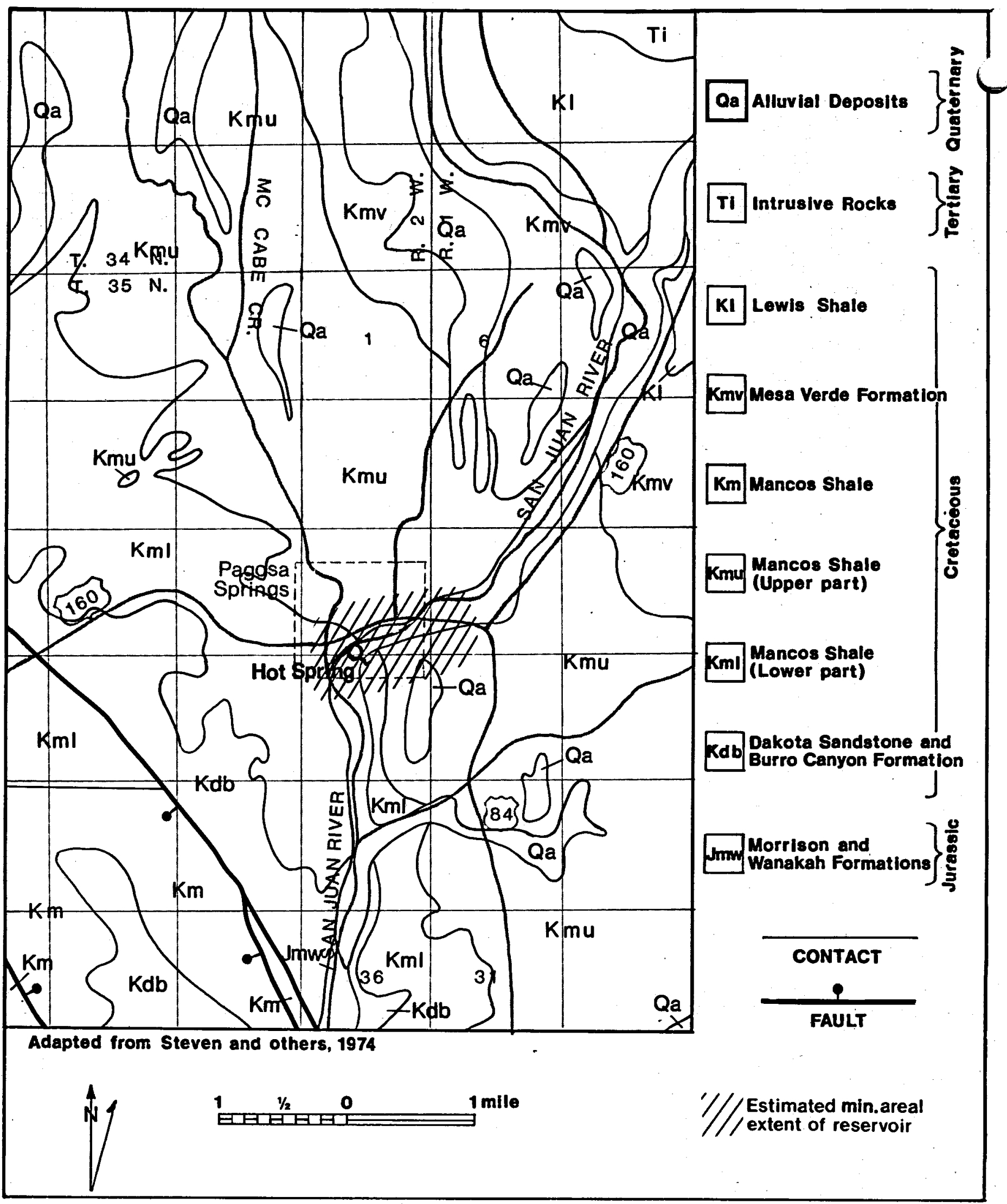

Figure 34.--Pagosa Springs, geology and estimated areal extent of the geothermal reservoir. 
is area is the Dakota Formation. All the units fountered were highly fractured but did not appear to be faulted. Therefore, it is postulated that the waters are moving up from depths along fracture zones and into the Dakota Formation. For - a complete description of the Pagosa Springs project the reader is referred to Galloway, 1979
For resource assessment purposes it was assumed that the Dakota reservoir has an areal extent of $1.0 \mathrm{sq} \mathrm{mi}$ and contains $.0226 \mathrm{Q}$ 's of energy (Table 2). It is possible that the primary reservoir is fractured Precambrian age rocks. As the size of this reservoir is not known at the present no estimate of its heat content were here made. 


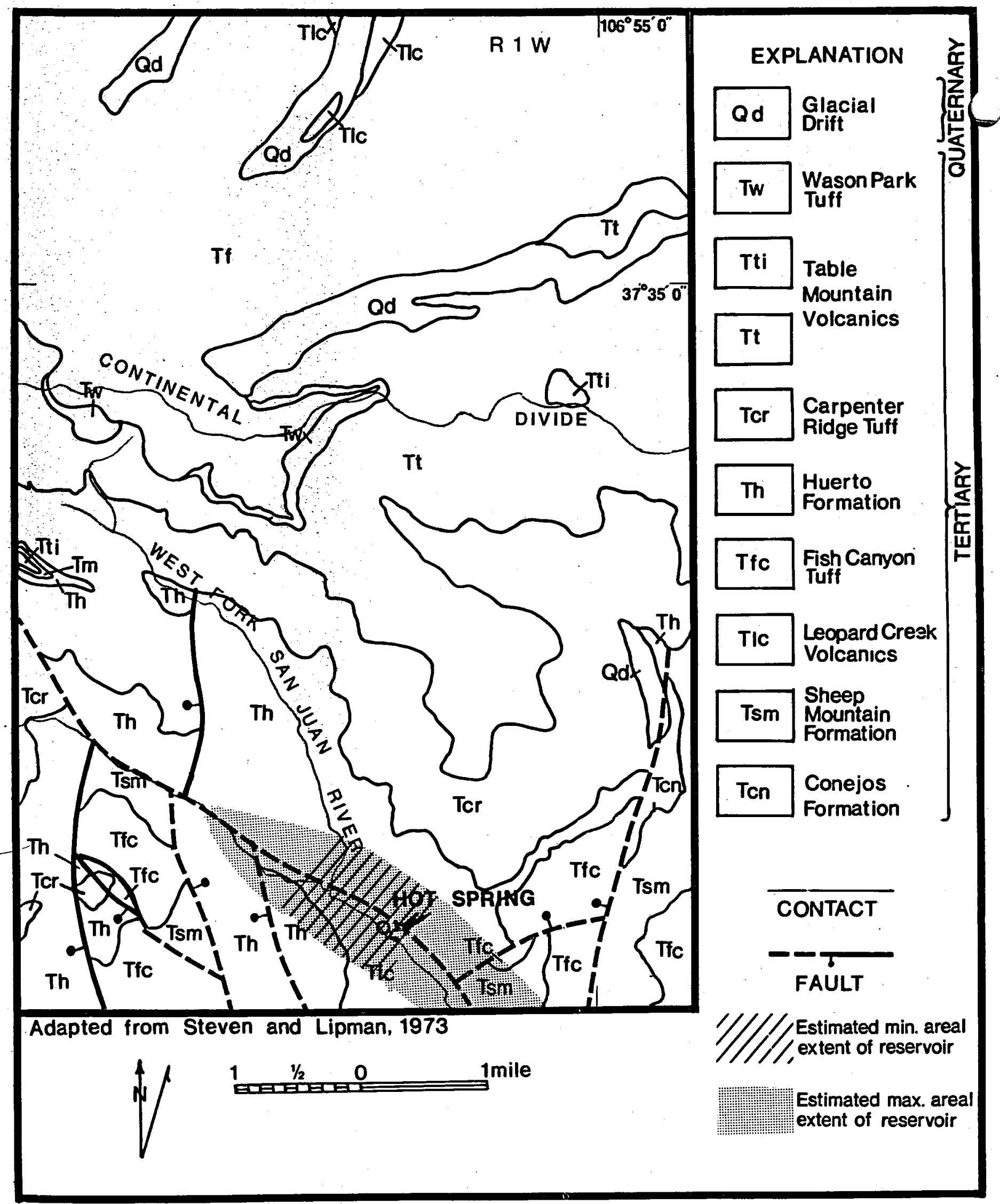

Figure 35.--Rainbow Hot Springs, geology and estimated areal extent of the geothermal reservoir. 


\section{\#42 RAINBOW HOT SPRING}

LOCATION: Latitude: $37^{\circ} 30^{\prime} 34^{\prime \prime} \mathrm{N}_{\text {.; }}$ Longitude: $106^{\circ} 56^{1} 52$ "W.; T. 38 N., R. 1 W., Sec. 9, N.M.P.M.; Mineral County; Spar City 15-minute topographic quadrangle map.

GENERAL: This unused spring is reached by walking approximately 6 miles up the West Fork of the San Juan River. Access is via a dirt road at the base of Wolf Creek Pass that turns from U.S. 160 to the West Fork Campground. Continue past the campground to the end of the road at the Borns Lake cabin area. Near this cabin area a marked foot trail leads to the spring.

GEOLOGY AND HYDROLOGY: When sampled in September, 1975 , the spring had a temperature of $40^{\circ} \mathrm{C}$, a discharge of $45 \mathrm{gpm}$, contained $161 \mathrm{mg} / \mathrm{l}$ of dissolved mineral matter, and was a sodium-bicarbonate type.

As mapped by Steven and Lipman (1973) (Fig. 35), the thermal waters emerge along a southeast-trending normal fault that closely follows the valley of Cimarron Creek and the West Fork of the San Juan River. It is believed that recharge to the spring is via deep circulation along fault zones in an area of above-normal geothermal gradients that are probably related to the oligocene volcanic activity that occurred in this region.

GEOTHERMOMETER ANALYSES: The cristobalite-silica geothermometer yielded an estimated subsurface temperature of $41^{\circ} \mathrm{C}$, which is very close to the surface temperature of the hot spring $\left(40^{\circ} \mathrm{C}\right)$ (Barrett and Pearl, 1978). Cristobalite mixing model analysis yielded a subsurface temperature estimate of $41^{\circ} \mathrm{C}$ with no shallow, cold ground water contained within the hot spring flow (Table 3 ). According to Barrett and Pearl (1978), the $\mathrm{Na}-\mathrm{K}$ and
Na-K-Ca geothermometers yield subsurface temperature estimates of $68^{\circ} \mathrm{C}$ and $22^{\circ} \mathrm{C}$, respectively (Table 3 ). The $\mathrm{Na-K}$ geothermometer estimate is too high because the basic assumption of the model was violated (Fournier and Truesdell, 1973). The Na-K-Ca geothermometer estimate is obviously incorrect because it is below the surface temperature of the hot spring. This low estimate may be due to temperature-dependent equilibration between the ascending thermal fluid and the potassium-deficient. Fish Canyon Tuff, a quartz-latitic ash fow tuff.

Conclusion: The rapid flow rate and close agreement between the silica geothermometer and mixing model results suggest that the subsurface temperature is not much higher than the surface temperature in this area. Therefore, the subsurface temperature in this area is probably between $40^{\circ} \mathrm{C}$ and $50^{\circ} \mathrm{C}(\mathrm{Tab}$ Te 3$)$.

RESOURCE ASSESSMENT: The occurrence of this spring is associated with the major faults in the area (Fig. 35). In assessing the extent of the reservoir, two estimates of its extent were made. As shown on Figure 35, the smaller area extending mainly to the west of the spring encompasses an area of approximately $1 \mathrm{sq} \mathrm{mi}$. The other area is much larger, $2.0 \mathrm{sq} \mathrm{mi}$, and extends along the fault zone from a point approximately 1.75 miles west of the spring to a point southeast of the spring. This area also encompasses the intersection of another major fault with the fault Rainbow Springs is located on.

It is estimated that this fault controlled reservoir contains between $.0470 Q^{\prime}$ s and .0940 Q's of heat energy, at an average maximum temperature of $45^{\circ} \mathrm{C}$ ( Table 2 ). 


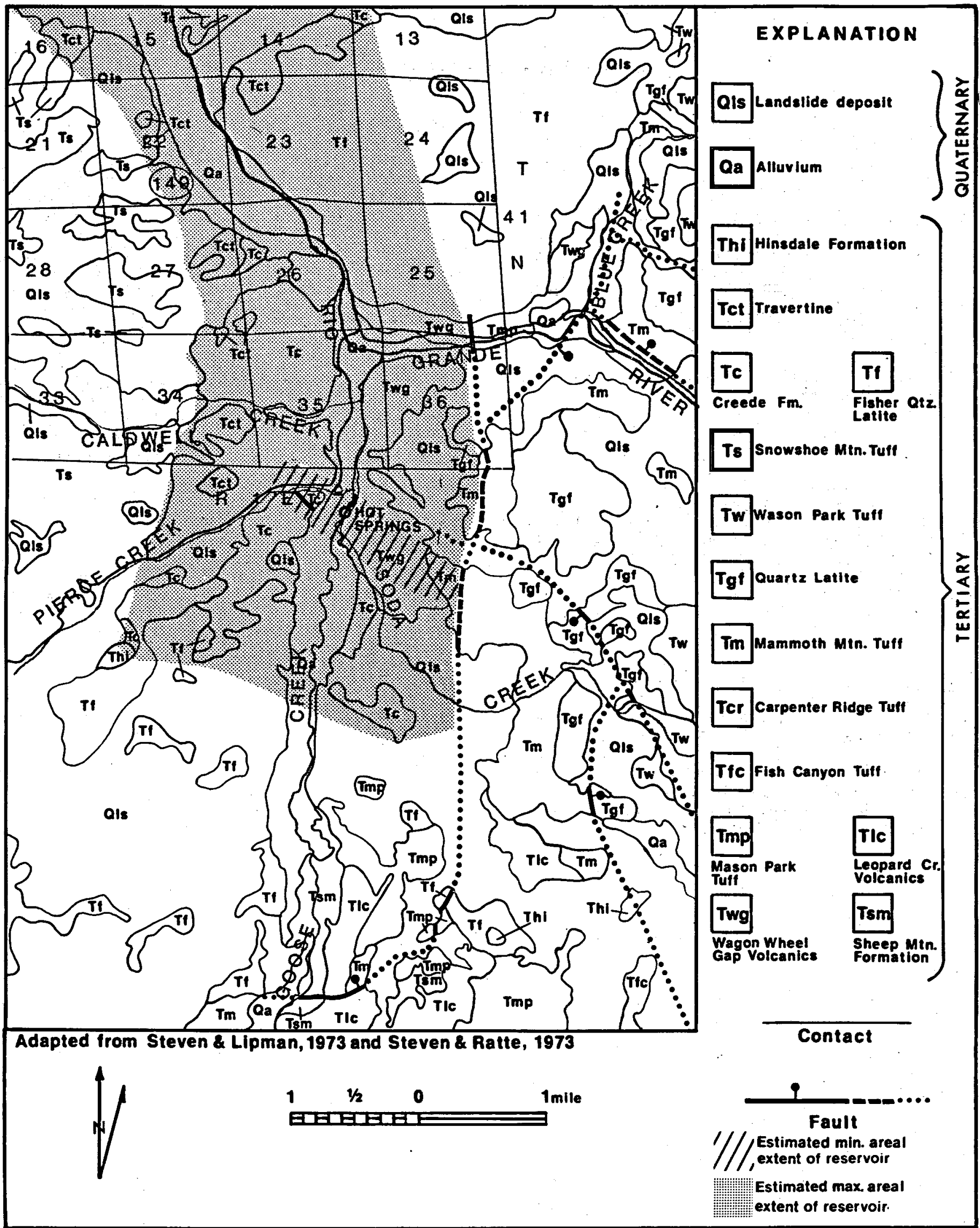

Figure 36.--Map of Wagon Wheel Gap Hot Springs region showing geology and estimated areal extent of the geothermal reservoir. 


\section{\#43 WAGON WHEEL GAP. HOT SPRINGS}

LOCATION: Latitude: $37^{\circ} 41^{\prime} 06^{\prime \prime}$.; Longitude: 106.49'47"W.; T. 41 N., R. 1 E.; Sec. 35 dd, N.M.P.M.; Mineral County; Spar City $71 / 2$-minute topographic quadrangle map.

GENERAL: This group of two springs is located approximately 10 miles southeast of Creede. Access is via a dirt road from State Highway 149 approximately $0.5 \mathrm{mile}$ west of the community of Wagon Wheel Gap and along the west side of Goose Creek.

Although these two springs are named for the community of Wagon Wheel Gap, they actually lie over $1 \mathrm{mile}$ south of town along both sides of Goose Creek. . One spring, the 4UR, is located on the 4UR Ranch, which is called the Wagon Wheel Gap Ranch on the topographic map. The other spring, here named the CFI Spring, is located on the east bank of Goose Creek approximately 200 yd south of the 4UR Spring. This unused spring is just south of the CFI Mine.

The spring on the 4UR Ranch is located at the south end of the compound and west-southwest of the old bathhouse building. The spring emerges into a large concrete-lined pool. Several springs flow into the pool, although the exact number is indeterminable. Since all of these springs are mixed, it was not possible to sample them individually. The waters are used in a new outdoor swimming pool and in a sauna bath.

\section{GEOLOGY AND HYDROLOGY:}

4UR Spring: The temperature of the spring varied from $55^{\circ} \mathrm{C}$ to $57^{\circ} \mathrm{C}$ throughout the year. The discharge of the spring was an estimated $30 \mathrm{gpm}$. The total dissolved mineral matter in the water also varied from $1,550 \mathrm{mg} / 1$ to $1,620 \mathrm{mg} / 1$. The water is a sodium-bicarbonate type.

CFI Spring: The temperature of the spring varied from $48^{\circ} \mathrm{C}$ to $51^{\circ} \mathrm{C}$ throughout the year. The discharge also varied from a low of $-48 \mathrm{gpm}$ to 51 gpm. The dissolved elemental mineral matter varied throughout the years time from $1,470 \mathrm{mg} / 1$ to 1,540 $\mathrm{mg} / 1$. The waters are a sodium-bicarbonate type.

The Wagon Wheel Gap Hot Springs are located on the southeast side of the central part of the Creede Caldera in the San Juan volcanic field. The geology of the Creede Caldera has been discussed in detail by Steven and Ratte (1973), Steven and Lipman (1973), and others. The authors have shown that this area was the center of extensive volcanic activity in 01 igocene time and has had a long and varied geologic history.

Barrett and Pearl (1978) made no attempt to describe the hydrogeological conditions of the area in detail. They believed that the springs are rerharged in the immediate vicinity where the * jrs move down through fault zones. The waters ina be stored in some of the more permeable intervolcanic beds.
At one time the Creede Caldera may have been quite thermally active. Steven and Ratte (1973) mapped extensive travertine deposits extending from the 4UR Spring northward to the Rio Grande River, west up the river to the vicinity of Creede, then southwest to the edge of the Creede quadrangle (Fig. 36). None of these deposits were mapped in the Spar City quadrangle; however, it is believed that from the nature of their occurrence in the Creede quadrangle that they may also extend into the Spar City quadrangle. Steven (1969b) described these deposits to be of cold-water origin. White (1967) on the other hand believes that they were formed by thermal waters:

As shown on the accompanying geologic map (Fig. 36), the waters of both springs emerge through alluvial deposits overlying the Creede Formation which consists of stream, lake, and pyroclastic deposits (Steven and Lipman, 1973). As shown on the geologic map, no faults were mapped in the vicinity of the CFI spring; however, one of the few faults in the area lies within a few hundred yards of the 4UR spring.

GEOTHERMOMETER ANALYSES: Emmons and Larson (1913) reported siliceous sinter and opaline silica east of the hot springs (Barrett and Pearl, 1978). If silica deposition still occurs at depth, then both the silica geothermometers and mixing model results are too low. The opaline silica suggests subsurface temperatures below $100^{\circ} \mathrm{C}$. However, the extensive fluorspar deposits indicate temperatures at depth between $119^{\circ} \mathrm{C}$ and $168^{\circ} \mathrm{C}$. If deposition of these minerals still occurs, then the subsurface temperature is probably between $100^{\circ} \mathrm{C}$ and $168^{\circ} \mathrm{C}$. At any rate, the geochemistry of these springs is too complex for a reliable subsurface temperature estimate.

As the silica content of these springs does not approach the solubility of amorphous silica, chalcedony, cristobalite, or quartz, the application of the silica geothermometers will yield questionable results. However, the amorphous silica geothermometer yields a maximum subsurface temperature estimate of $12^{\circ} \mathrm{C}$, which is well below the surface temperature of the warm springs $148^{\circ} \mathrm{C}$ to $\left.51^{\circ} \mathrm{C}\right)$. The cristobalite-silica geothermometer subsurface temperature estimate is $66^{\circ} \mathrm{C}$ to $81^{\circ} \mathrm{C}$ (Table 3 ). However, this estimate is probably too high because the theoretical cristobalite solubility $(50 \mathrm{mg} / 1)$ at the spring's surface temperature is well below the silica content of the thermal water $(67 \mathrm{mg} / 1$ to $90 \mathrm{mg} / 1$ ) (Barrett and Pearl, 1978).

According to Barrett and Pearl (1978), Amorphous Mixing Model yielded a subsurface temperature estimate of $43^{\circ} \mathrm{C}$ with a cold-water fraction of 40 percent. This temperature estimate is also below the surface temperature of the spring, suggesting that amorphous silica probably does not control the silica content of the thermal water. 
The cristobalite mixing model yields a subsurface temperature estimate that ranges from $99^{\circ} \mathrm{C}$ to $157^{\circ} \mathrm{C}$ with a cold-water fraction of 56 percent to 76 percent of the spring flow. For the same reason given above, the estimates are probably too high (Barrett and Pearl, 1978).

The $\mathrm{Na}-\mathrm{K}$ and $\mathrm{Na}-\mathrm{K}-\mathrm{Ca}$ geothermometers yield subsurface temperature estimates of $200^{\circ} \mathrm{C}$ to $206^{\circ} \mathrm{C}$ and $181^{\circ} \mathrm{C}$ to $194^{\circ} \mathrm{C}$, respectively. Al though none of the springs deposit calcium carbonate, considerable calcium carbonate occurs in association with nearby fluorspar and barite deposits. If deposition occurs at depth, then both the $\mathrm{Na}-\mathrm{K}$ and $\mathrm{Na}-\mathrm{K}-\mathrm{Ca}$ geothermometer estimates are too high.

RESOURCE ASSESSMENT: In assessing the possible extent of this thermal system, consideration was given to the fact that it occurs within the Creede Caldera and that there are extensive travertine deposits in the area. Even though some doubt exists regarding the origin of these travertine deposits (see Barrett. and Pearl, 1978), the boundaries of the area were drawn to include them (Fig. 36).
In trying to assess this area, it war recognized that this thermal system could be ve' narrowly restricted to a small area around the springs. Therefore, two estimates were made. One estimate restricted the reservoir to. an area running from the possible major fault to the east to just west of the small fault west of the spring. Alternatively, it was postulated that this smali fault might extend to the southeast and intersect the major fault. If this fault did, it then could be the conduit along which the waters are moving up from depth. The area could encompasses approximately $.7 \mathrm{sq} \mathrm{mi}$ and coñain .0625 Q's ôf heat energy at an average maximum temperature of $115^{\circ} \mathrm{C}$ (Table 2).

The other area is by necessity much larger (Fig. 36) and includes all the travertine deposits in the area. It is believed that until proven otherwise, this area should be considered to contain a geothermal resource. This area as drawn encompasses some $16.0 \mathrm{sq} \mathrm{mi}$ and could contain $1.4285 Q^{\prime} s$ of heat energy at an average temperature of $115^{\circ} \mathrm{C}$ (Table 2 ). 


\section{ANTELOPE AND BIRDSIE WARM SPRINGS}

Located in the upper reaches of the Rio Grande River Valley west of Creede, Colorado, are two small springs whose characteristics and mode of occurrence are nearly identical.

\section{\#44 ANTELOPE WARM SPRING}

LOCATION: Latitude: $37^{\circ} 44^{\prime} 36^{\prime \prime N}$; Longitude: 10702 14"W.; T. 40 N., R. 2 W.: Sec. 1 dd, N.M.P.M.; Mineral County; Workman 7 1/2-minute topographic quadrangle map.

GENERAL: Antelope warm spring is located behind a Targe Tog building approximately 1 mile north of Colorado 1.49 and approximately 12 miles west of
Creede, Colorado. This unused spring is at the base of a small concrete-lined cistern.

HYDROLOGY: The spring has a discharge estimated to be 3 gpm with a temperature of $32^{\circ} \mathrm{C}$. The total dissolved mineral matter in the waters is $150 \mathrm{mg} / \mathrm{l}$, and the waters are a sodium-bicarbonate type.

\section{\#45 BIRDSIE WARM SPRING}

LOCATION: Latitude: $37^{\prime} 43^{\circ} 42^{\prime \prime N}$.; Longitude: $107^{\circ} 00^{\prime} 44^{\mathrm{WW}}$.; T. 40 N., R. 2 K., Sec. 14 abc, N.M.P.M.; Mineral County; Workman $71 / 2-m i n u t e$ topographic quadrangle map.

GENERAL: This unused spring is located along

GEOLOGY OF ANTELOPE AND BIRDSIE WARM SPRINGS: These springs are located on the west side of the Creede Caldera, an area of extensive middle Tertiary volcanic activity. The geology of the area has been described in detail by Steven and Ratte (1973).

The geologic map (Fig. 37), based in part on Steven and Ratte (1973), shows that Antelope Spring emerges from glacial drift which oveljes volcanic rocks. Birdsie Warm Spring emerges from Tertiary volcanic rocks. These springs do not appear to be fault controlled, for few faults are mapped the vicinity of the springs (Fig. 37). No attempt was made during this investigation to accurately determine the hydrogeological conditions surrounding these springs. However, the spring may originate from southward down-gradient flow of ground waters through permeable intravolcanic zones that dip into the center of the caldera, an area with above-normal heat flow. Reiter (1975) has shown the upper Rio Grande River valley to have a heat flow in excess of 2.5 heat flow units.

GEOTHERMOMETER ANALYSES OF ANTELOPE AND BIRDSIE SPRINGS: Analysis suggests that cristobalite controls the silica content of the warm springs. The cristobalite-silica geothermometer yields a subsurface temperature estimate of $43^{\circ} \mathrm{C}$ for Antelope Warm Spring and $52^{\circ} \mathrm{C}$ for Birdsie Warm ciring (Table 3 ).

Since temperature-dependent equilibration between the thermal water and cristobalite
Colorado 149 approximately 14 miles west of Creede, Colorado.

HYOROLOGY: The discharge of this spring was measured at $15 \mathrm{gpm}$ with a temperature of $30^{\circ} \mathrm{C}$. The waters had a conductance of 200 micromhos and a $\mathrm{pH}$ of 8.6 .

apparently controls the silica content of the warm springs, the Cristbalite Mixing Model is applicable (Barrett and Pearl, 1978). Mixing Model analys is of Antelope Warm Spring yields a subsurface temperature estimate of $55^{\circ} \mathrm{C}$ with a cold water fraction of 44 percent of the spring flow. The Mixing Model estimate for:Birdsie Warm Spring is $91^{\circ} \mathrm{C}$ with a cold-water fraction of 70 percent. These estimates are within the range of values that could result from normal analytical error.

The $\mathrm{Na}-\mathrm{K}$ and $\mathrm{Na}-\mathrm{K}-\mathrm{Ca}$ geothermometers yield subsurface temperature estimates of $83^{\circ} \mathrm{C}$ to $102^{\circ} \mathrm{C}$ and $35^{\circ} \mathrm{C}$ to $36^{\circ} \mathrm{C}$, respect ively (Table 3 ). The $\mathrm{Na}-\mathrm{K}$ geothermometer estimate is too high as the basic assumption of the model is violated (Fournier and Truesde11, 1973).

Conclusion: Most geothermometer techniques are not reliable when applied to Antelope and Birdsie Warm Springs because many of the assumptions inherent in their use are violated. The close agreement between the Cristobalite-Silica and the $\mathrm{Na}-\mathrm{K}-\mathrm{Ca}$ geothermometers suggests subsurface temperatures between $35^{\circ} \mathrm{C}$ to $52^{\circ} \mathrm{C}$ (Tabie 3 ).

RESOURCE ASSESSMENT: As noted earlier, the reasons for the occurrence of these springs is imperfectly understood. They may occur due to the flow of hot waters through permeable inter volcanic zones or they might be associated with unmapped fault zones. Steven (1967) has shown that faulting may exist a few miles north of each springs (Fig. 37). These faults could be extended southward into the 


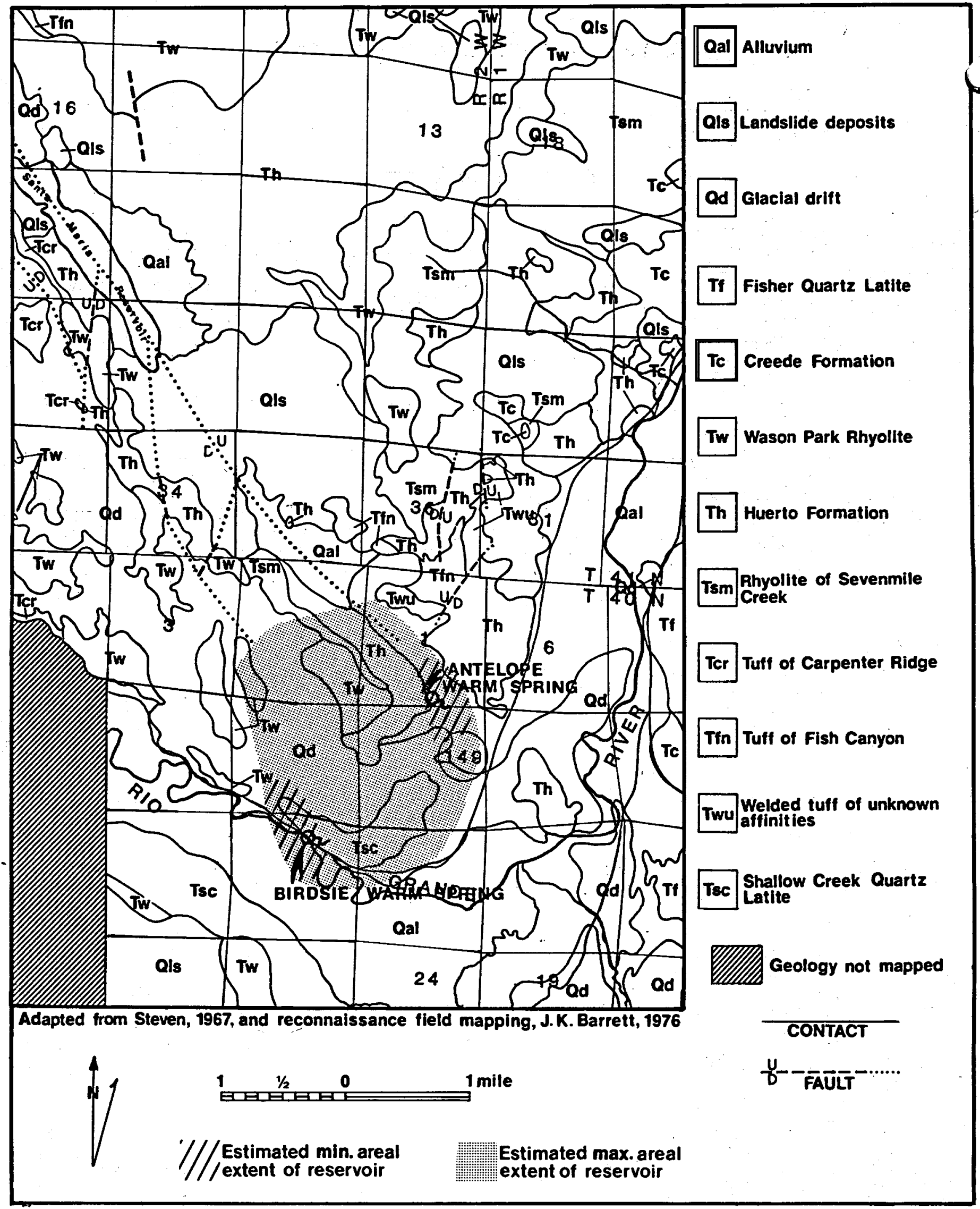

Figure 37.--Map of Antelope and Birdsie Warm Springs region showing geology and estimated areal extent of the geothermal reservoir. 
vicinity of the springs with very little fficulty. If this is the case then the springs e partly fault controlled.

In assessing the extent of these systems, the above parameters were taken into consideration. In the conservative case, it was felt that the reservoirs were restricted to a small area around each spring. In this estimate, the combined extent of the reservoirs encompassed an area of .50 $\mathrm{sq} \mathrm{mi}$ and contained $.0113 \mathrm{Q}^{\prime}$ 's of energy at a temperature of $44^{\circ} \mathrm{C}$.

For the other estimate it was assumed that both springs were part of one large system (Fig. 37) that contained part of the postulated fautts. This area was estimated to contain approximately $3.90 \mathrm{sq} \mathrm{mi}$ and contain .0880 Q's of energy (Table 2). The extent of this system is difficult to estimate, for it could be restricted to a small area around each spring or it could encompass a much 1 arger area. 


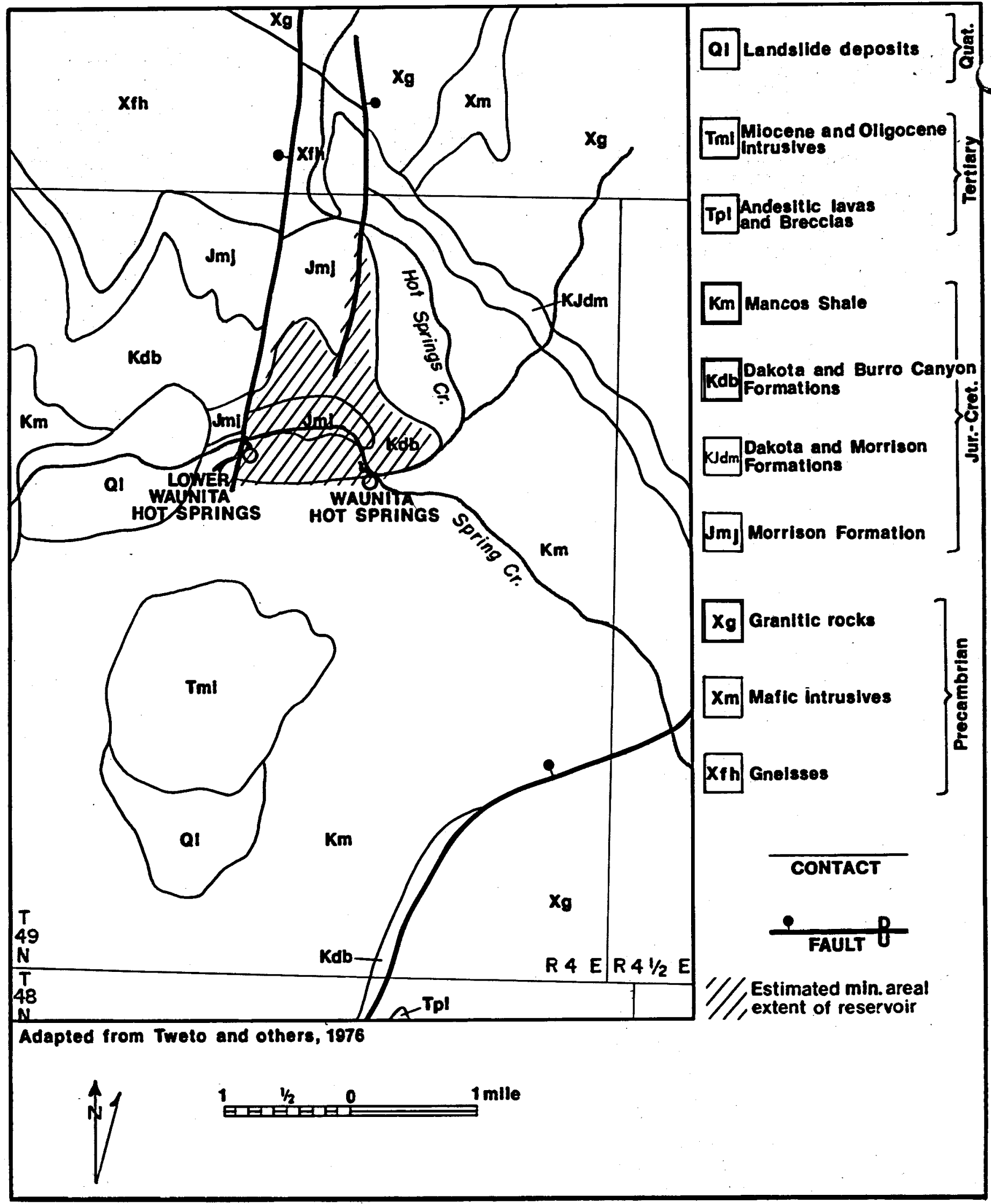

Figure 38.--Map showing estimated areal extent of the Waunita Hot Springs geothermal reservoir and surrounding geologic conditions. 


\title{
\#46 UPPER AND LOWER WAUNITA HOT SPRINGS
}

\author{
\#46 UPPER WAUNITA HOT SPRINGS
}

LOCATION: Latitude: $38^{\circ} 30^{\prime} 50^{\prime \prime} N . ;$ Longitude: $106^{\circ} 30^{\top} 27^{\prime \prime W}$; T. 49 N., R. 4 E., Sec. $11 \mathrm{cc}$, N.M.P.M.; Gunnison County; Pitkin 7 1/2-minute topographic quadrangle map.

GENERAL: This group of four springs is reached by traveling east from Gunnison, Colorado, on U.S. Highway 50 for 19 miles, and north on a well marked county road for approximately 8 miles. The springs are located on the southeast side of the ranch headquarters building. Haters from the springs are used for swimming, drinking, and heating the headquarters building. All the springs are located in front of the ranch headquarters building along Hot Springs Creek.

Spring $A$, the hottest spring, is located in a gazebo-like structure. This spring is extensively developed with the waters being pumped to the buildings. It was not possible to obtain a sample of the waters for analys is because an iron grill prohibited access.

Spring B is located approximately $75 \mathrm{ft}$ south of $A$ on the same side of the creek. The discharge of this spring was not large and it was not possible to measure it.

Spring $C$ and $D$ are located on the opposite side of Hot Springs Creek from Springs $A$ and $B$. Spring $C$, the largest spring, is located south of the old swimming pool. Spring $D$ flows into the old swimming pool, and due to severe: leaking, a discharge measurement could not be obtained. A sample of the water was obtained from the east end of the pool.

\section{GEOLOGY AND HYDROLOGY:}

Spring A: Temperature: $76^{\circ} \mathrm{C}$; Discharge: not determined; Conductance: 750 micromhos.

Spring B: Temperature: $78^{\circ} \mathrm{C}$; Discharge: not determined; Conductance: 720 micromhos.

Spring C: Temperature: 77 to $80^{\circ} \mathrm{C}$; Discharge varied throughout the year, measured from $30 \mathrm{gpm}$ to $55 \mathrm{gpm}$. The total dissolved solids during the period varied from $557 \mathrm{mg} / 1$ to $613 \mathrm{mg} / 1$; the water is a sodium-sulfate type.

\section{\#46 LOWER WAUNITA HOT SPRINGS}

LOCATION: Latitude: $38^{\circ} 31^{\prime} 00^{\prime \prime N}$.; Longitude: $106^{\circ} 30^{\circ} 55^{\prime \prime} W_{;}$T. 49 N., R. 4 E., Sec. $10 \mathrm{bc}$, N.M.P.M.; Gunnison County; Pitkin 7 1/2-minute topographic quadrangle map.

GENERAL: This large group of unused springs is located approximately 0.5 mile to the west down Hot Springs Creek from the Waunita Hot Springs resort. Access is along a dirt trail from the Waunita Hot Springs resort buildings.

The Lower Waunita Hot Springs consists of three separate groups of springs extending over several hundred yd in length. The major spring in each group was selected for measurements.

The northern group (Group A) was named Spring $A$, the biggest spring on the east side of the group. Group B contains a cistern-like structure and several seeps. Springs in Group $C$ emerge from the old abandoned rock buildings at the south end

GEOLOGY OF UPPER AND LOWER WAUNITA HOT SPRINGS: The Waunita Hot Springs are located on the north side of the Tomichi Dome, a Tertiary intrusive that has ched the overlying Mancos Shale. Very litte has en written on the geology of this part of Colorado. The one article describing the geology of the area. Spring $C$ emerges from beneath the old steambath building. Group $D$ is located around the old gazebo along the creek. Spring $D$ is the spring in the gazebo.

\section{HYDROLOGY:}

Spring A: Temperature: $75^{\circ} \mathrm{C}$; Discharge: estimated at $75 \mathrm{gpm}$; Conductance: 765 micromhos.

Spring B: 'Temperature: $70^{\circ} \mathrm{C}$; Discharge: est imated at $20 \mathrm{gpm}$; Total Dissolved Solids: Varied from 528 $\mathrm{mg} / 1$ to $544 \mathrm{mg} / 1$; Water Type: sodium sulfate-bicarbonate.

Spring C: Temperature: $70^{\circ} \mathrm{C}$; Discharge: $8 \mathrm{gpm}$; Conductance: 780 micromhos.

Spring D: Temperature: $62^{\circ} \mathrm{C}$; Discharge: not determined; Total Dissolved Solids: $535 \mathrm{mg} / 1$; Water Type: sodium sulfate-bicarbonate.

of the area (Stark and Behre, 1936) describes the Tomichi Dome.

The accompanying geologic map (Fig. 38), taken from Tweto and others (1976), shows that the upper springs are situated on the contact between the 
Dakota Sandstone and the overlying Mancos Shale. The lower springs are located along a fault zone. It is believed that the upper spring waters migrate up from depth along the contact between the Dakota and Mancos.

GEOTHERMOMETER ANALYSES OF UPPER AND LOWER WAUNITA HOT SPRINGS: The quartz-silica gethermometer est imate of the subsurface temperature is $143^{\circ} \mathrm{C}$ to $157^{\circ} \mathrm{C}$ for Waunita Hot Springs and $123^{\circ} \mathrm{C}$ to $130^{\circ} \mathrm{C}$ for Lower Waunita Hot Springs (Table 3). (Barrett and Pearl, 1978). Mixing model analysis yields a subsurface temperaure estimate of $209^{\circ} \mathrm{C}$ to $291{ }^{\circ} \mathrm{C}$ with a cold-water fraction of 64 to 83 percent for Waunita Hot Springs and a subsurface temperature estimate of $181^{\circ} \mathrm{C}$ to $208^{\circ} \mathrm{C}$ with a cold water fraction of 64 to 73 percent for Lower Waunita Hot Springs (Table 3 ).

According to Barrett and Pearl (1978), Waunita Hot Spring D and Lower Waunita Hot Spring D are the least suitable springs for mixing model analysis, but yield the highest subsurface temperature estimates of the group $\left(291^{\circ} \mathrm{C}\right.$ and $208^{\circ} \mathrm{C}$, respectively). Waunita Hot Spring D was sampled from a large, quiescent pool. Lower Waunita Hot Spring $D$ appears to be partially flooded by a nearby stream. Excluding these two springs, the subsurface temperature estimates range from $209^{\circ} \mathrm{C}$ to $247^{\circ} \mathrm{C}$ for Waunita Hot Springs and $181^{\circ} \mathrm{C}$ to $197^{\circ} \mathrm{C}$ for Lower Waunita Hot Springs.

The seasonal fluctuation of the subsurface temperature estimates suggests that the assumed cold water analysis and the percent-mixing estimates do not adequately represent the hydrological condition at depth. However, certain conclusions can be made from thestestimates because they are within the range of values that could result from normal analytical error.

The $\mathrm{Na}-\mathrm{K}$ and $\mathrm{Na}-\mathrm{K}-\mathrm{Ca}$ geothermometers yjeld subsurface temperature estimates of $174^{\circ} \mathrm{C}$ to $179^{\circ} \mathrm{C}$ and $159^{\circ} \mathrm{C}$ to $167^{\circ} \mathrm{C}$, respectively, for both hot springs groups. The high surface temperature $\left(70^{\circ} \mathrm{C}\right.$ to $\left.80^{\circ} \mathrm{C}\right)$, flow $(100$ to $200 \mathrm{gpm})$, and close agreement with the mixing model results suggest that the $\mathrm{Na}-\mathrm{K}$ and $\mathrm{Na}-\mathrm{K}-\mathrm{Ca}$ geothermometer models provide reasonable estimates for this area.

Conclusion: The close agreement between the Mixing mode $\mathrm{T}$ and the $\mathrm{Na}-\mathrm{K}-\mathrm{Ca}$ model estimates suggests that these geothermometers adequately reflect the temperature at depth. Therefore, consideration of these results and the precision of the geothermometers suggests temperatures at depth between $175^{\circ} \mathrm{C}$ and $225^{\circ} \mathrm{C}$ (Table 3 ).

RESOURCE ASSESSMENT: In estimating the size of this reservoir, the geologic conditions of the area were taken into consideration. It was noted that the springs are either associated with the Dakota Formation or faults. Therefore, the boundaries of the area were drawn along the contacts of the Dakota Formation and parts of the fault zones (Fig. 38). As drawn, the areal extent of the system encompasses some $1.4 \mathrm{sq} \mathrm{mi}$ and contains approximately .0606 Q's of heat energy having an average maximum temperature of $135^{\circ} \mathrm{C}$ (Table 2$)$. 


\title{
\#47 CEBOLLA HOT SPRINGS
}

\author{
(FORMERLY KNOWN AS POWDERHORN, HOT SPRINGS)
}

LOCATION: Latitude: $30^{\circ} 16^{\prime} 26^{\prime \prime N}$; Longitude: $107^{\circ} 05^{\prime} 54^{\prime \prime}$ W. ; T. 46 N., R. 2W., Sec 4 ab, N.M.P.M.; Gunnison County; Powderhorn 7 1/2-minute topographic quadrangle map.

GENERAL: This group of three fairly large springs is located approximately 30 miles southwest of Gunnison, Colorado, just off Highway 149 along Cebolla Creek. At one time these springs were extensively developed and used, but today all the old buildings and the swimming pool are gone and all that remains are two small wooden buildings.

The springs are used today for bathing purposes. Two springs emerge into a large cistern-like structure in the southernmost building and the other spring is located in the large building approximately $75 \mathrm{ft}$ to the northwest.

GEOLOGY AND HYDROLOGY: Due to modifications of the area around the springs, it was not possible to accurately measure the discharge. However, a fairly reliable discharge of $3 \mathrm{gpm}$ was obtained for one of the two springs in the southern building. All three springs have a temperature of $38^{\circ} \mathrm{C}$ to $40^{\circ} \mathrm{C}$ (depending on time of year when measured) with total dissolved mineral matter of $1,450 \mathrm{mg} / 1$. The waters are a sodium-bicarbonate type.

As mapped by Hedlund and 01 son (1975) (Fig. 39 ), these springs are located $300 \mathrm{ft}$ from the southeast trending Cimarron Fault. The bedrock of the area consists of complex assemblages of Precambrian metamorphic rocks, Cambrian and Ordovician intrusives, and 0ligocene volcanic-derived rodks. It appears. that that thermal activity in the geologic past was was very extensive in this area, for indicators of such activity have been mapped by Heduland and 01 son (1975) along the Cimarron Fault west of the Cebolla Hot Springs.

As the Precambrian rock types are not good aquifers, the springs probably originate from deep circulation along the Cimarron Fault system in an area of elevated geothermal gradients. Reiter (1975) has determined that the Cebolla Hot Springs area has a heat flow of just over 2.5 heat flow units.

GEOTHERMOMETER ANALYSIS: Geothermometer models must be used with caution when applied to Cebolla Hot Springs since most of the assumptions inherent in their use are violated. Moreover, samples of the thermal water had to be taken from large, quiescent pools. Such sampling conditions may exaggerate the effects of the surface conditions on the thermal water, allowing evaporative concentration of the silica content and other reequilibration rèactions to occur.

Analysis of silica solubility and temperature relationships suggest that cristobal ite may control the silica content of the hot springs. Therefore, the cristobalite-silica geothermometer was used to determine the most reliable subsurface temperature estimate (Barrett and Pearl, 1978).

The cristobalite-silica geothermometer estimate of subsurface temperature is $65^{\circ} \mathrm{C}$ to $82^{\circ} \mathrm{C}$. This estimate is probably too high because the theoretical cristobalite-induced silica solubility $(39 \mathrm{mg} / 1)$ at the surface temperature of the springs $\left(38^{\circ} \mathrm{C}\right.$ to $\left.41^{\circ} \mathrm{C}\right)$ is well below the silica content of the springs (77 to $92 \mathrm{mg} / 1)$.

Cristobalite mixing model analysis yields subsurface temperature estimates of $105^{\circ} \mathrm{C}$ to $185^{\circ} \mathrm{C}$ with a cold water fraction of 66 to 83 percent of the spring flow (Table 3 ).

Cristobalite mixing model estimated temperatures based on the January and April, 1976 samples range from $163^{\circ}$ to $185^{\circ} \mathrm{C}$ with a cold-water fraction of 80 to 83 percent of the spring flow (Table 3). normal analytical error.

The $\mathrm{Na}-\mathrm{K}$ and $\mathrm{Na}-\mathrm{K}-\mathrm{Ca}$ geothermometers estimates of $238^{\circ} \mathrm{C}$ to $278^{\circ} \mathrm{C}$ and $209^{\circ} \mathrm{C}$ to $220^{\circ} \mathrm{C}$, respectively. Travertine deposits mapped in sections 33 and 34 , T. 47 N.; R. $2 \mathrm{~W}$. and sections $2,3,11,12$, T. 46 N., R. 2 W. by Hedlund and 01 son (1975) (not shown on Fig. 39) suggest that both the $\mathrm{Na}-\mathrm{K}$ and the $\mathrm{Na}-\mathrm{K}-\mathrm{Ca}$ geothermometer estimates are too high. In addition, the geothermometers may yield erroneous results when applied to the high magnesium waters of these springs.

Conclusion: The geochemistry of these waters is too complex for an accurate estimation of - the temperature at depth.

RESOURCE ASSESSMENT: Barrett \& Pear1 (1978) stated that they believed the occurrence of these thermal waters is due to deep circulation of waters along the Cimarron Fault. Heduland and 01 son (1975) mapped extensive sinter and travertine deposits northwest of the spring along Cebolla Creek.

As no clear cut controlling feature is available, reservoir boundaries were drawn (Fig. 39) to include many of the sinter and travertine deposits of Hedlund \& 01 son (1975). The area is estimated to be $1.28 \mathrm{sq} \mathrm{mi}$ in extent and contain approximately .0481 $Q^{\prime} s$ of heat energy (Table 2). 


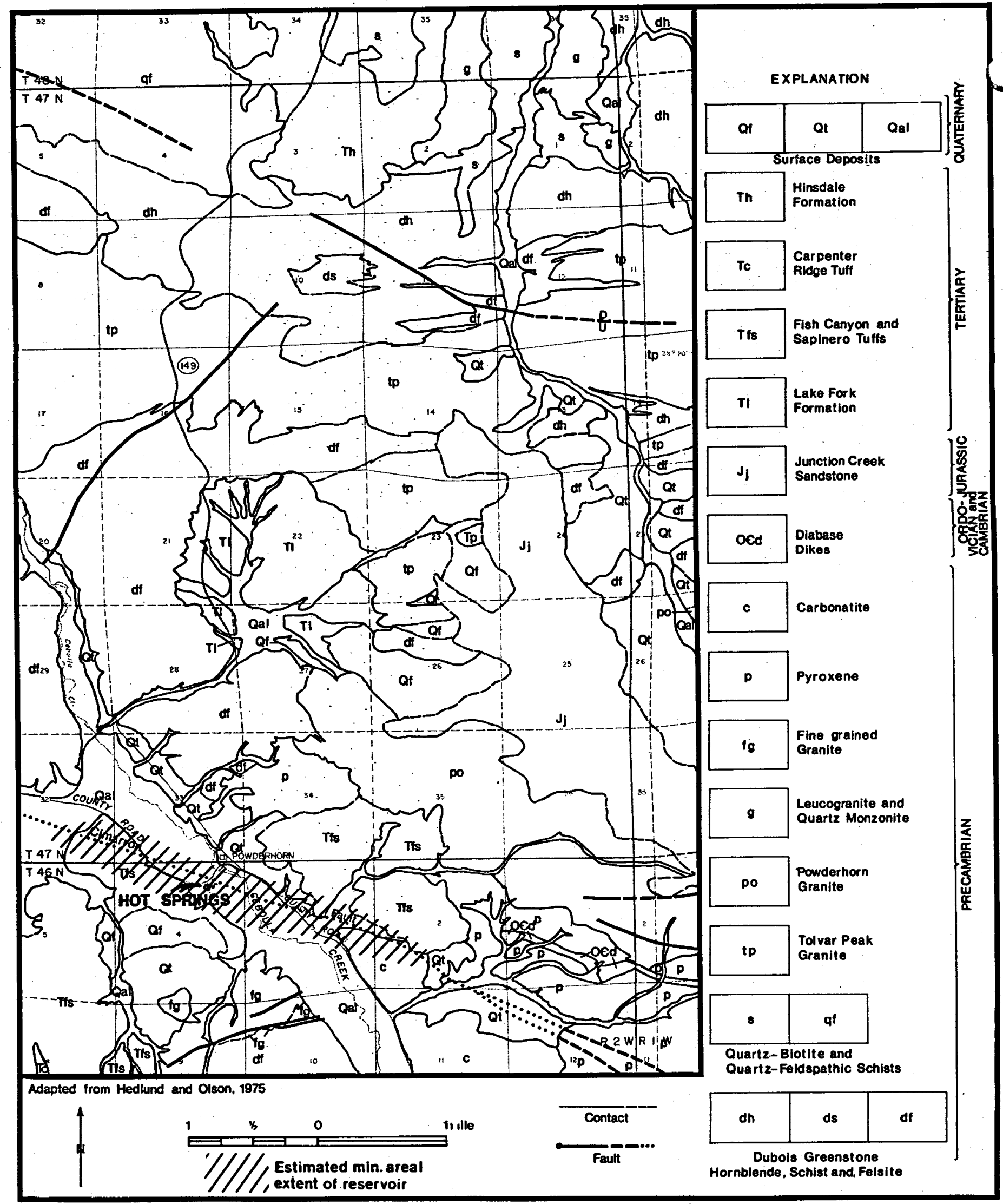

Figure 39.--Geology surrounding Cebolla Hot Springs and estimated areal extent of the geothermal reservoir. 


\section{\#48 ORVIS HOT SPRING}

LOCATION: Latitude: $38^{\circ} 07^{\prime} 59^{\prime \prime N}$.; Longitude 107.4401"W.; T. 45 N., R. -8 W., Sec. $22 \mathrm{~cd}$, N.M.P.M.; Ouray County; Dallas 7 1/2-minute topographic quadrangle map.

GENERAL: This spring is located on the west side of U.S. Highway 550 approximately 9 miles north of Ouray. Waters from the spring are diverted and piped approximately 200 yd to the north to a building for use in hydrotherapy.

GEOLOGY AND HYDROLOGY: No water issues from the spring today due to the waters being diverted to the nearby buildings. The spring has a temperature of $52^{\circ} \mathrm{C}$ and contains approximately $2,300 \mathrm{mg} / 1$ of dissolved mineral matter. The waters are a sodium sulfate type with a high concentration of iron.

Although the waters ascend through the alluvial and colluvial deposits of the valley floor, they are associated with the underlying red beds of the Morrison Formation. While geologic mapping ( $F i g .40$ ) does not show any possible origin for this spring, it is believed that the waters must move up fracture systems related to the San Juan and La Plata Mountains to the south, for geologic mapping to the west on Dallas Divide (Bush and others, 1956) has shown an extens ive network of faults and folds. It is believed that water ascends some fractures that must be present in the vicinity of Orvis Hot Springs. Recharge to this system probably occurs to the south along the flanks of the San Juan Mountains. Reiter (1975) has shown Ouray to be an area of high heat flow (greater than 2.5), and presumably the origin of the heat for the Orvis Hot Springs is related to this high heat flow.
GEOTHERMOMETER ANALYSES: Barrett and Pearl (1978) calculated the following subsurface temperatures: $75^{\circ} \mathrm{C}$ to $82^{\circ} \mathrm{C}$ with chalcedony silica geothermometer, - $99^{\circ} \mathrm{C}$ to $127^{\circ} \mathrm{C}$ with a cold water fraction of 54 to 66 percent with the chalcedony mixing model, $179^{\circ} \mathrm{C}$ to $187^{\circ} \mathrm{C}$ with the $\mathrm{Na}-\mathrm{K}$ geothermometer, which is definitely too high because the conditions of the model has been violated, and $93^{\circ} \mathrm{C}$ to $97^{\circ} \mathrm{C}$ with the $\mathrm{Na}-\mathrm{K}-\mathrm{Ca}$ geothermometer mode1. Extensive travertine deposits, calcium carbonate-cemented gravels, and calcium-depositing seeps near the hot spring suggest that both the $\mathrm{Na}-\mathrm{K}$ and $\mathrm{Na}-\mathrm{K}-\mathrm{Ca}$ geothermometer estimates are too high.

Conclusion: Geothermometer models must be used with caution when applied to Orvis Hot Spring since most of the assumptions inherent in their use are violated. Samples of the thermal water had to be taken from a large, quiescent pool. Such sampling conditions may exaggerate the effects of the surface conditions on the thermal water, allowing evaporative concentration of the silica content and other re-equilibration reactions to occur.

RESOURCE ASSESSMENT: In order to make sure that the full possible extent of the system would be included, two estimates of the systems extent were made. The smaller estimate restricted the reservoir to an area of $.55 \mathrm{sq} \mathrm{mi}$ around the spring. The other area was estimated to be much larger, $2.53 \mathrm{sq} \mathrm{mi}$. Since no real geologic reasoning was used in selecting these two extents other than it was felt that these areas would encompass much of the Morrison Formation, the supposed reservoir.

Calculations show that the energy contained in this system ranges from $0.0284 Q^{\prime} s$ to $0.1308 Q^{\prime} s$ at an average maximum temperature of $75^{\circ} \mathrm{C}$ ( Table 2). 


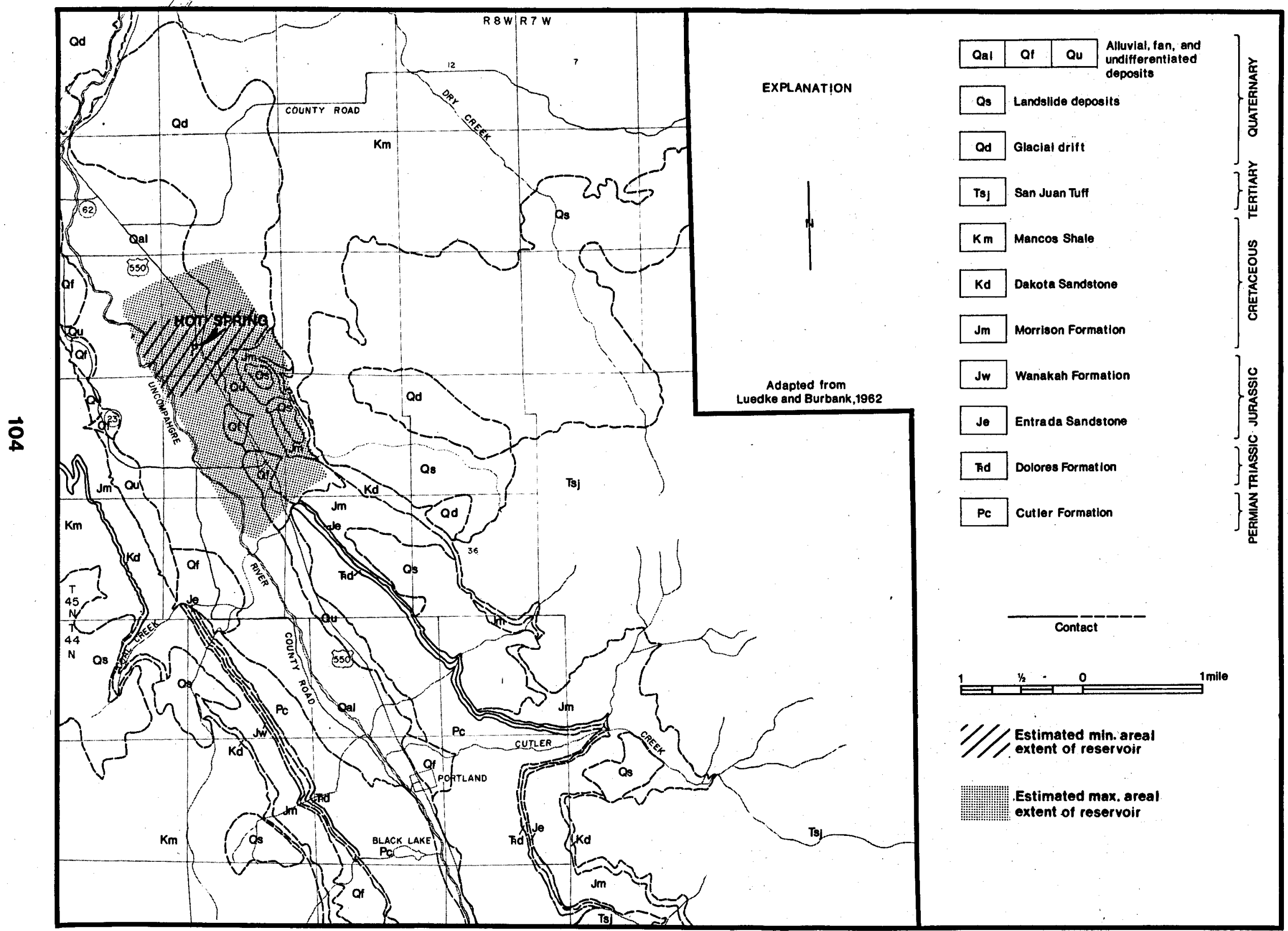

C

Figure 40.--Orvis Hot Spring, geology and estimated areal extent of the geothermal reservoir. 


\section{\#49 OURAY HOT SPRINGS}

In and adjacent to the City of Ouray are a number of hot springs, most of which have small discharges, usually less than $5 \mathrm{gpm}$. However, the largest and hottest of the springs, the Pool Spring, has a discharge that varies throughout the year from a low of $69 \mathrm{gpm}$ to a high of $200 \mathrm{gpm}$. This spring is located at the upper reaches of Box Canyon.

LOCATION OF THERMAL SPRINGS LOCATED AND MEASURED:

Pool Spring: Latitude: $38^{\circ} 01^{\prime} 00^{\prime M}$.; Longitude: $107^{\circ} 40^{\top} 41^{\prime \prime}$. ; T. 44 N., R. 7 W., Sec. 31 , N.M.P.M.; Ouray County; Ouray 7 1/2-minute topographic quadrangle map.

Uncompahgre Hot Spring: Latitude: $38^{\circ} 01^{\prime} 06^{\prime N}$.; Longitude: $107^{\circ} 40^{\prime} 34^{\prime \prime} W_{0}$; T. 44 N., R. 7 W., Sec. 31 , N.M.P.M.; Ouray County; Ouray $71 / 2$-minute topographic quadrangle map.

Wiesbaden Vapor Caves and Motel Hot Springs: Located in basement of the Wi esbaden motel at the corner of $6 \mathrm{th}$. Avenue and $5 \mathrm{th}$ Street are three springs. Latitude: $38^{\circ} 01^{\prime} 15^{\prime \prime N}$.; Longitude: $107^{\circ} 40^{\prime} 03^{\prime \prime W . ; ~ T . ~} 44$ N., R. 7 W., Sec. 31, N.M.P.M.; Ouray County; Ouray $71 / 2$ minute topographic quadrangle map.

GENERAL: With the exception of the Uncompahgre Hot Spring, several seeps in Box Canyon, and the springs at the rear of Box Canon Motel, all the thermal waters in the Ouray vicinity are used. The waters from the Pool Hot Spring are piped from Box Canyon to the swimming pool on the north end of town. Waters from the Wiesbaden Springs are used for the motel's mineral baths, swimming pool, and space heating.

GEOLOGY AND HYDROLOGY: As "stated earlier, the discharge of the Pool Spring varies throughout the year from a low of $60 \mathrm{gpm}$ to a high of $200 \mathrm{gpm}$. The temperature of the waters is a very consistent, $67^{\circ} \mathrm{C}$ to $69^{\circ} \mathrm{C}$. The waters contain approximately $1,650 \mathrm{mg} / \mathrm{l}$ of dissolved solids and are a calcium-sulfate type. The concentration of radiochemical elements, Radium226 and Radium228, in the Pool Spring exceeds the U.S. Environmental Protection Agency Protection Agency limits for drinking water supplies (Barrett and Pearl, 1978). Due to the alterations at both the swimming pool and the spring site, it was only possible to obtain water samples when the pipel ine dumps into a concrete cistern near 0ak creek.

The Uncompahgre Hot Spring has a discharge of $5 \mathrm{gpm}$ with a temperature of $49^{\circ} \mathrm{C}$. The waters contain $1,570 \mathrm{mg} / 1$ of dissolved solids and are a calcium sulfate type. The spring was sampled on the Uncompangre River, below a sheer cliff approximately 100 yd upstream from the $3 d$ Ave. britge.

The Wiesbaden Motel Hot Springs are located in vapor caves beneath the motel at the corner of 6 th
Ave. and 5 th St. Spring $A$ has a temperature of $53^{\circ} \mathrm{C}$ and contains $910 \mathrm{mg} / 1$ of dissolved solids. The waters are a calcium-sulfate type. This spring was sampled from the cistern just to the left inside the cave entrance. Spring $B$ was sampled at the back of the cave from a ledge about $8 \mathrm{ft}$ above the floor. The spring has an estimated discharge of $2 \mathrm{gpm}$. The waters contain $410 \mathrm{mg} / 1$ of dissolved solids and are a calcium sulfate type. Spring C, located in the furthest corner of the cave, has a discharge which varies between one $\mathrm{gpm}$ and $30 \mathrm{gpm}$ throughout the year. The waters from this spring contain approximately $800 \mathrm{mg} / 1$ of dissolved solids and are a calcium-sulfate type.

Due to the complexity of the geological conditions in the area, no definitive statements can be made regarding the geological conditions controlling the occurrence of these springs ( $F i g$. 41). All the springs appear to be associated with one or mope fault systems, and they apparentiy represent deep circulation of ground water through the fault systems of the region.

Thermal springs have been reported to the south in the Red Mountain Pass area (Kevin McCarthy, 1977 , oral communication). These springs have not been located or sampled yet.

GEOTHERMOMETER ANALYSES: Due to the extensive modifications made to most of the hot springs for recreation and space heating, only data from Pool Hot spring will be discussed in the following sections. Geothermometer results for Pool Hot Spring and the other hot springs in this area are listed. in Table 3 .

According to Barrett and Pearl (1978), the chalcedony-silica geothermometer yield a subsurface temperature of $69^{\circ} \mathrm{C}$ to $71^{\circ} \mathrm{C}$, which is very near the surface temperature of the spring $\left(67^{\circ} \mathrm{C}\right.$ to $\left.69^{\circ} \mathrm{C}\right)$.

Chalcedony mixing model anlysis yields a subsurface temperature estimate of $77^{\circ} \mathrm{C}$ to $79^{\circ} \mathrm{C}$ with a cold water fraction of 15 to 16 percent of the spring flow (Barrett and Pearl, 1978).

The $\mathrm{Na}-\mathrm{K}$ and $\mathrm{Na}-\mathrm{K}-\mathrm{Ca}$ geothermometers yields a subsurface temperature estimate of $184^{\circ} \mathrm{C}$ to $192^{\circ} \mathrm{C}$ and $39^{\circ} \mathrm{C}$, respectively (Table 3 ). The $\mathrm{Na}-\mathrm{K}$ geothermometer. estimate is definitely too high because the basic assumption of the model is violated (Barrett and Pearl, 1978). The Na-K-Ca geothermometer estimate is incorrect because the result is below the surface temperature of the hot spring.

Conclusion: The high flow (approximately $175 \mathrm{gpm}$ ) of this hot spring and close agreement between the silica geothermometer and mixing model estimates suggests temperatures at depth between $70^{\circ} \mathrm{C}$ and $90^{\circ} \mathrm{C}$ (Table:3).

RESOURCE ASSESSMENT: The geologic conditions of this area are very complex (Barrett \& Pearl, 1978). Therefore, it is very difficult to draw the 


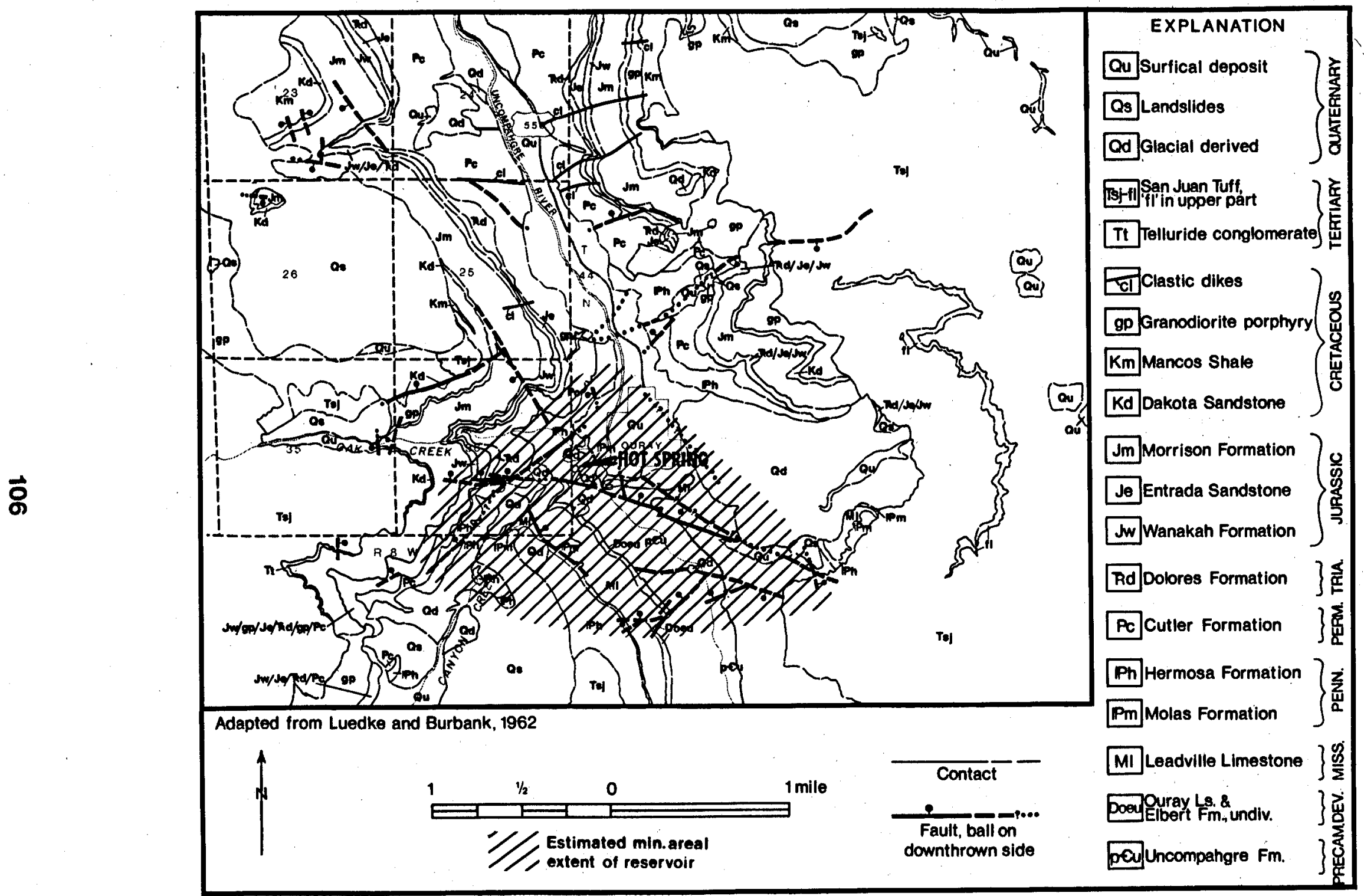

Figure 41.--Map of Ouray area showing geology and estimated areal extent of the geothermal reservoir. 
hnundaries of this system with any degree of fidence. Barrett \& Pearl (1978) stated that ty believed the waters were associated with one or more of the faults found in the region. The boundaries were drawn to try and include as much of the faulting as possible. Also, as unconfirmed thermal springs have been reported to the south in the Red Mountain Pass Region the southern boundary was drawn to extend in that direction.

It is estimated that this areal extent of the system could encompass approximately $2.00 \mathrm{sq} \mathrm{mi}$ and contain .2256 Q's of heat energy at an average maximum temperature of $80^{\circ} \mathrm{C}$ (Table 2 ). 


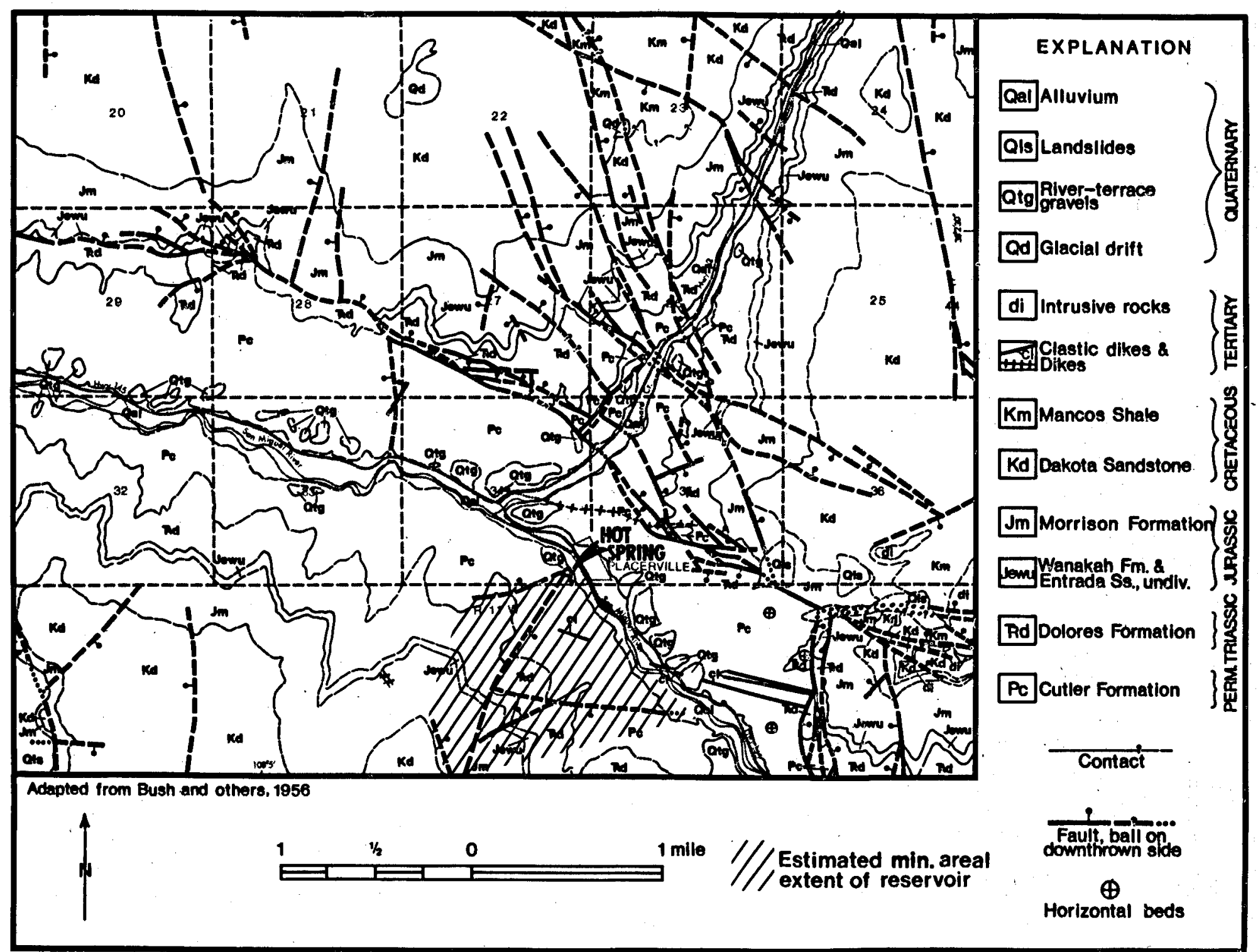

Figure 42.--Map of Lemon Hot Springs area showing geology and estimated areal extent of the geothermal reservoir. 


\section{\#50 LEMON HOT SPRING}

LOCATION: Latitude: $38^{\circ} 51^{\prime} 00^{\prime \prime N . ; ~ L o n g i t u d e: ~}$ 108 $03^{\top} 11^{\prime \prime} W_{\text {. }}$ T. 44 N., R. 11 W., Sec. $34 \mathrm{dd}$, N.M.P.M.; San Miguel County; Placerville 7 1/2-minute topographic quadrangle map.

GENERAL: This unused spring is located in a tunne1 driven into the Dolores Formation on the west bank of the San Miguel River in the community of Placerville 17 miles northwest of Telluride on Highway 145.

GEOLOGY AND HYDROLOGY: Barrett and Pearl (1978) reported that the spring has a discharge of 8 to 10 gpm at a temperature of 31 to $33^{\circ} \mathrm{C}$. The waters contain from 2,740 to $2,810 \mathrm{mg} / 1$ of dissolved solids and are a mixed sodium bicarbonate-sulfate type. The surrounding area is geologically very complex, for the area is a transition zone between the Uncompahgre Plateau to the north and the La Plata Mountains to the south. A number of large north-trending fault zones and grabens intersect northwest-trending fault zones paralleling the San Miguel River. These north-south structures die out at the San Miguel River. Although none of these structures are mapped on the south side of the river (Fig. 42), one of them, the Sheep Draw Graben and associated faults, are on trend with the Lemon Warm Spring. The spring itself is located at the intersection and termination of one small and one large fault. Even though these faults are not apparent within the tunnel at the spring site, it is believed that they control the origin of the spring. It is believed that the waters migrate up these faults from depth. The waters come from the red beds of the Triassic Dolores Formation (Fig. 42). Recharge is probably to the south and west along the flanks of the La Plata Mountains.

GEOTHERMOMETER ANALYSES: Analys is by Barrett and Pearl (1978) showed that the amorphous-silica geothermometer should yield the most reliable subsurface temperature estimate. The amorphous-silica geothermometer estimate of subsurface temperature is $14^{\circ} \mathrm{C}$ to $17^{\circ} \mathrm{C}$, which is below the surface temperature of the hot spring $\left(31^{\circ} \mathrm{C}\right.$ to $\left.33^{\circ} \mathrm{C}\right)$. This low estimate may be caused by dilution of the ascending thermal water by shallow ground water.

The amorphous-silica mixing model analysis yields a subsurface temperature estimate of $29^{\circ} \mathrm{C}$ to $31^{\circ} \mathrm{C}$ with a cold-water fraction of 15 to 17 percent. of the spring flow. Although the subsurface temperature estimate is below the surface temperature of the hot spring $\left(33^{\circ} \mathrm{C}\right)$, it is well within the expected margin of error (Barrett and Pear1, 1978).

According to Barrett and Pearl's (1978) calculations the $\mathrm{Na}-\mathrm{K}$ and $\mathrm{Na}-\mathrm{K}-\mathrm{Ca}$ geothermometers yield subsurface temperature estimates of $203^{\circ} \mathrm{C}$ to $210^{\circ} \mathrm{C}$ and $192^{\circ} \mathrm{C}$ to $198^{\circ} \mathrm{C}$, respectively. The nearby occurrence of travertine deposits, calcium carbonate-cemented river gravels and the 1ack of substantiation of such high temperature estimates by the other geothermometers suggest that these estimates are excessive.

Conclusion: The low surface temperature and flow of this hot spring renders geothermometer analys is unreliable.

RESOURCE ASSESSMENT: The boundaries of this system were drawn to include most of the faulting at the south side of the San Miguel River (Fig. 42). As drawn, the system encompasses an area of approximately . $80 \mathrm{sq} \mathrm{mi}$. Calculations show that it could contain $.0149^{\prime} Q^{\prime} s$ of energy at an average maximum temperature of $43^{\circ} \mathrm{C}$ (Table 2 ). 


\section{\#51 DUNTON HOT SPRING}

LOCATION: Latitude: $37^{\circ} 46^{\prime} 18^{\prime \prime} N_{\text {; }}$ Longitude $108^{\circ} 05^{\prime} 38^{\prime \prime}$.; T. 41 N., R. 11 W.; Sec. 32 , N.M.P.M.; Dolores County; Dolores Peak 7 1/2-minute topographic quadrangle map.

GENERAL: This spring is located at the old mining town of Dunton, which is now a resort area northwest of $R i c o$. Access is via a dirt road which turns off of Colorado 145 approximately 2 miles north of Rico or alternatively via a dirt county road up the Hest Dolores River starting a few miles west of Stoner. The spring is located at the base of the hill east of the main buildings. The waters are piped approximately 30 yd to a building where they empty into a large pool and are used for bathing. The waters are drained from this pool to the West Dolores River.

GEOLOGY AND HYDROLOGY: The waters of these springs are a calcium bicarbonate type with a strong concentration of iron (up to $2,300 \mathrm{mg} / 1$ ) and manganese (average concentration of $1,800 \mathrm{mg} / 1$ ). The temperature of the spring is $42^{\circ} \mathrm{C}$ with a discharge of $25 \mathrm{gpm}$. The surrounding bedrock are the red sandstones, siltstones, and shales of the Dolores Formation. The red color and high iron content of the spring water confirm that the waters are associated with the Dolores Formation.

The surface of the ground is mantled with a veneer of red sandstones and shales which makes difficult the determination of the true geologic conditions of the area. As shown on the accompanying geologic map (Fig. 43), several major north-northwest trending faults, with major displacement, pass through or are located only a short distance from Dunton. The fault on which the Dunton Hot Spring is located has dropped the Morrison Formation down into contact with the Entrada and Dolores Formations.

The recharge area of these springs is unknown but is probabiy to the south with the spring resulting from deep circulation along fault zones in an area of high geothermal gradients.
In 1922, E. Bastin visited the Emma Mine (approximately 0.5 mile south of Dunton Hot Spring) and reported a warm spring (Temp. $82^{\circ} \mathrm{F}$ ) located in the mine, $3000 \mathrm{ft}$ from the main portal.

GEOTHERMOMETER ANALYSES: The various geothermometer calculated subsurface temperatures are (Barrett and Pearl, 1978): $51^{\circ} \mathrm{C}$ to $54^{\circ} \mathrm{C}$ by the chalcedony-silica geothermometer, $65^{\circ} \mathrm{C}$ to $69^{\circ} \mathrm{C}$ with a cold-water fraction of 39 to 43 percent by the mixing model, $328^{\circ} \mathrm{C}$ to $342^{\circ} \mathrm{C}$ with the $\mathrm{Na}-\mathrm{K}$ model. This estimate is too high because one of the basic assumptions of the model has been violated (Barrett and Pearl , 1978). The $\mathrm{Na}-\mathrm{K}-\mathrm{Ca}$ geothermometer model yields a temperature of $47^{\circ} \mathrm{C}$ to $52^{\circ} \mathrm{C}$ (Table 3 ).

Conclusion: The subsurface temperature in this area is probably between $50^{\circ} \mathrm{C}$ and $70^{\circ} \mathrm{C}$ (Table 3 ).

RESOURCE ASSESSMENT OF DUNTON, PARADISE, AND GEYSER HOT SPRINGS AREAS: White not proven, it is speculated that these three system's may be part of a larger system. Numerous faults have been mapped in the vicinity of these three springs (Fig. 43). Barrett \& Pearl (1978) speculated that the springs are probably fault controlled and the waters may also be associated with the Triassic Dolores Formation. Therefore, the boundaries of the system were drawn to include as many of these features as possible. It is estimated that this system may encompass an area of $1.20 \mathrm{sq}$ mi and contains .0271 $Q$ 's of heat energy (Table 2 ).

RESOURCE ASSESSMENT OF DUNTON HOT SPRING: While it is hypothesized that all three springs in this area could be part of one large system, it may be that this system lies at such a extreme depth that it would be economically unfeasiable to develope it. Therefore, estimates will be made of the possible areal extent of each individual thermal system.

The Dunton Hot Spring is located on the trace of a north trending fault. It is conjuctered that the extent of the reservoir around the fault would encompass and area of approximately $.03 \mathrm{sq} \mathrm{mi}$ and contain .0068 Q's of heat energy (Table 2). 


\section{\#52 GEYSER WARM SPRING}

LOCATION: Latitude: $37^{\circ} 44^{\prime} 48^{\prime \prime} \mathrm{N}$; Longitude: 10807'02"; T. 40 N., R. 11 W., Sec. 6 N.M.P.M.; Dolores County; Rico 7 1/2-minute topographic quadrangle map.

GENERAL: This spring, as implied by its name, is a true geyser, the only true geyser in the State of Colorado. Although the frequency of the eruption varies, 30 minute intervals are most common. The 'geyser action is slight and boils only 12 to $15 \mathrm{in}$. above the quiescent level of the spring (Barrett and Pearl, 1978).

The spring is reached via a 2-mile foot trail that starts approximately 1.5 miles south of Dunton and approximately 0.5 mile north of the Paradise Ranch buildings. The trail crosses the West Dolores River and runs east.

GEOLOGY AND HYDROLOGY: Due to the physical make up of the area around the spring and the geyser action, it was not possible to accurately measure the spring's discharge, but it is estimated to be 25 to $200 \mathrm{gpm}$. The temperature of the spring is $28^{\circ} \mathrm{C}$, and the waters are a sodium-bicarbonate type. The waters contain $1,620 \mathrm{mg} / 1$ of dissolved solids (Barrett and Pearl, 1978).

Bush and Bromfield (1966) have mapped the location of this spring near the intersection of two faults (Fig. 43), a postulated northeast-trending fault and a postulated northwest-trending fault. The waters emerge from the Dolores Formation, which overlies the Pennsylvanian Cutler Formation. The Dolores Formation consists of red siltstones, sandstone, shale, and a few limestone-pebble conglomerate beds (Bush and Bromfield, 1966). The intense faulting in the area makes reliable predictions of the recharge areas difficult.

GEOTHERMOMETER ANALYSES: Calculations by Barrett and Pearl (1978) show that the chalcedony-silica geothermometer yields a subsurface temperature est imate of $58^{\circ} \mathrm{C}$, the cristobal ite mixing model an estimate of $113^{\circ} \mathrm{C}$ with a cold water fraction of 80 percent of the spring flow, the Na-K geothermometer a temperature of $183^{\circ} \mathrm{C}$, and the $\mathrm{Na}-\mathrm{K}-\mathrm{Ca}$ geothermometer a temperature of $160^{\circ} \mathrm{C}$ (Table 3 ). Travertine deposits near the warm spring and the lack of substantiation of such high temperatures by the other geothermometers suggest that the $\mathrm{Na}-\mathrm{K}$ and $\mathrm{Na}-\mathrm{K}-\mathrm{Ca}$ estimates are too high.

Conclusion: The mixing model and silica geothermometers yield the most reliable estimates of subsurface temperature for Geyser Warm Spring. The subsurface temperature suggested by these geothermometers is between $60^{\circ} \mathrm{C}$ and $120^{\circ} \mathrm{C}$ (Table 3).

RESOURCE ASSESSMENT: This spring is located at the intersection of two faults (Fig. 43). It is postulated that this reservoir could extend for a short distance along both faults. If it does, it could encompass an area of approximately .03 sq $\mathrm{mi}$. Calculations show that an area of this size having an average maximum temperature of $50^{\circ} \mathrm{C}$ could contain .0068 Q's of heat energy (Table 2).

It was also postulated that this spring could be part of a much larger system that also included the Dunton Hot Spring and the Paradise Hot Spring. For an analysis of this system see the Resource Assessment for Dunton Hot Springs section. 


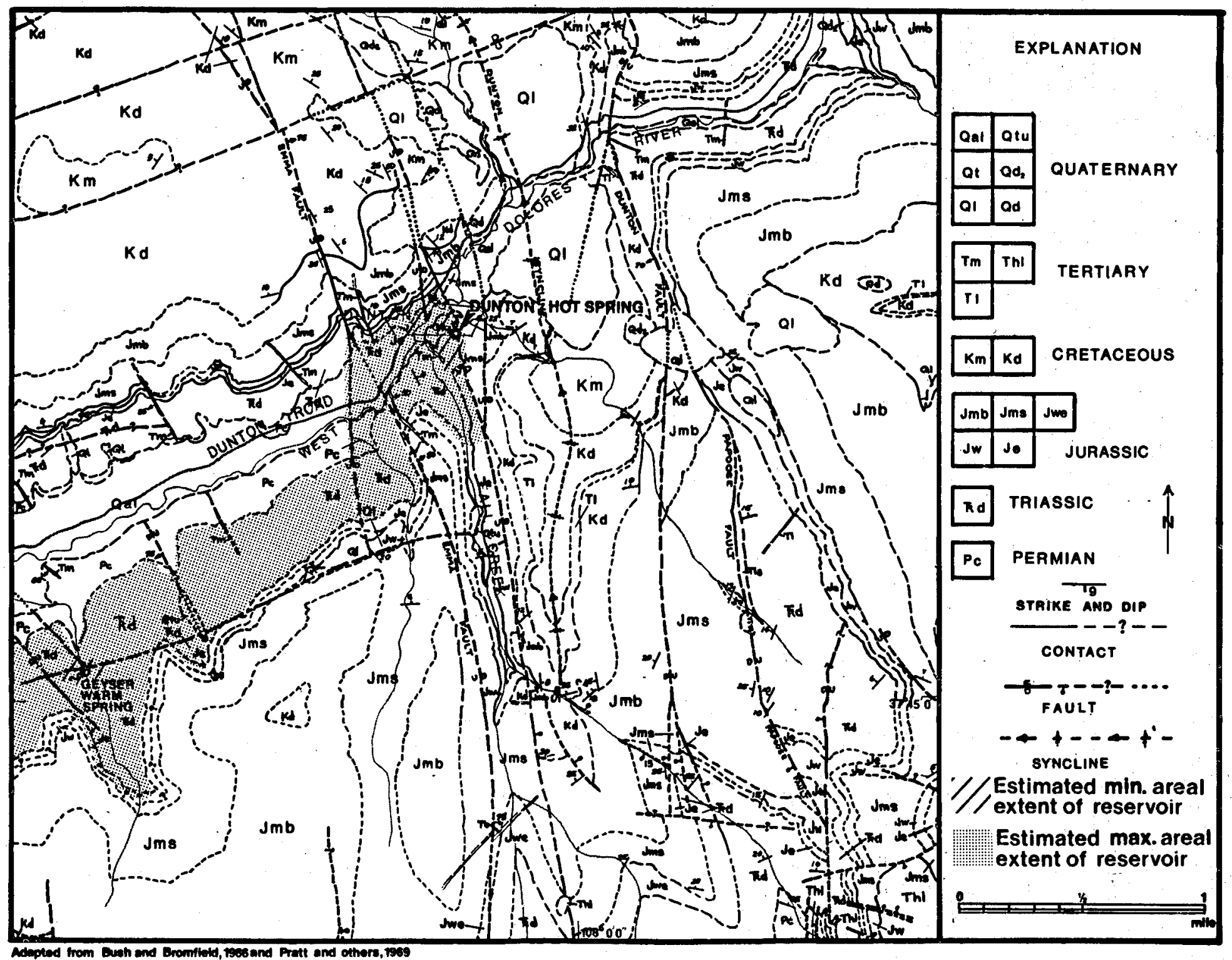

Figure 43.--Map of Dunton and Geyser Hot Springs area showing geology and estimated areal extent of the geothermal reservoirs. 


\section{\#53 PARADISE WARM SPRING}

LOCATION: Latitude: $37^{\circ} 45^{\prime} 15^{\mathrm{N} N . ;}$ Longitude: $108^{\circ} 07^{\top} 53$ "W.; T. 40 N., R. 12 W., Sec. 1, N.M.P.M.; Dolores County; Groundhog Mountain 7 1/2- minute topographic quadrangle map.

GENERAL:- This spring is located approximately 2.6 miles south of Dunton, Colorado on the northeast bank of the West Dolores River. Access is via the paved and dirt county road from State Highway 145 along the West Dolores River. The main spring is located in the large 1 og building at the ranch headquarters. Several seeps are reported in the pasture between the buildings and the river, but they were not located. The spring in the building flows into a large concrete cistern and is used privately by the owners for mineral baths. Evidentiy the thermal waters were used in the past to heat the large swimming pool just south of the log building.

GEOLOGY AND HYDROLOGY: The waters of this spring have a temperature that ranges throughout the year from $40^{\circ} \mathrm{C}$ to $46^{\circ} \mathrm{C}$. The total dissolved sol ids varied from a low of $6,070 \mathrm{mg} / 1$ to a high of 6,530 $\mathrm{mg} / 1$. The waters are a sodium chloride type with a discharge of 26 to $34 \mathrm{gpm}$. When it was possible to gain access to the building, the spring was sampled from the edge of the cistern. Other times it was sampled from the outfall discharge pipe on the south side of the building.

Since no previously published geologic map exists for this area, no geologic map was prepared for this report. Detailed geologic mapping has not been done near this spring, but one can assume that some of the faults mapped in the quadrangle to the north (see Dunton Hot Spring, No. 51) extend into the vicinity of this spring. The waters emerge through West Dolores River alluvium which overlies the red sandstones, shales, and siltstones of the Dolores Formation.

GEOTHERMOMETER ANALYSES: Computation of the silica solubility and temperature relationships for this spring suggest that amorphous silica may control the silica content of the warm waters. The amorphous silica geothermometer gave an estimated subsurface temperature of $39^{\circ} \mathrm{C}$ to $56^{\circ} \mathrm{C}$ (Table 3 ) (Barrett and Pear], 1978).

According to Barrett and Pearl (1978), amorphous silica mixing model analysis yields a subsurface temperature estimate of $43^{\circ} \mathrm{C}$ to $45^{\circ} \mathrm{C}$ with a cold water fraction of 1 to 4 percent of the spring flow (Table 3 ).

The $\mathrm{Na}-\mathrm{K}$ and $\mathrm{Na}-\mathrm{K}-\mathrm{Ca}$ geothermometers yield subsurface temperature estimates of $245^{\circ} \mathrm{C}$ to $247^{\circ} \mathrm{C}$ and $248^{\circ} \mathrm{C}$ to $252^{\circ} \mathrm{C}$, respectively. These estimates should be treated skeptically for the magnesium content $(30 \mathrm{mg} / \mathrm{l})$ of the spring may be effecting the geothermometers.

Conclusion: Geothermometer models must be used with caution when applied to Paradise Warm Spring because most of the assumptions inherent in their use are violated. The ambiguous nature of the geochemistry precludes any reliable subsurface temperature estimtes.

RESOURCE ASSESSMENT: As described earlier (see Resource Assessment of Dunton Hot Spring, Geyser Warm Spring and Paradise Warm Spring under Dunton Hot Spring) this spring might be part of a much larger system. However, because it was recognized that it may not an estimate of its areal extent was made.

This area is not shown on any geologic map; therefore, it was not possible to make any estimate of the reservoirs areal extent. Based on the authors knowledge of the area, it is estimated that the reservoir could encompass an area of $1.0 \mathrm{sq} \mathrm{mi}$. If this is so, then this area could could contain approximately $.0226 \mathrm{Q}$ 's of heat energy at an average maximum temperature of $50^{\circ} \mathrm{C}$ (Table 2$)$. 


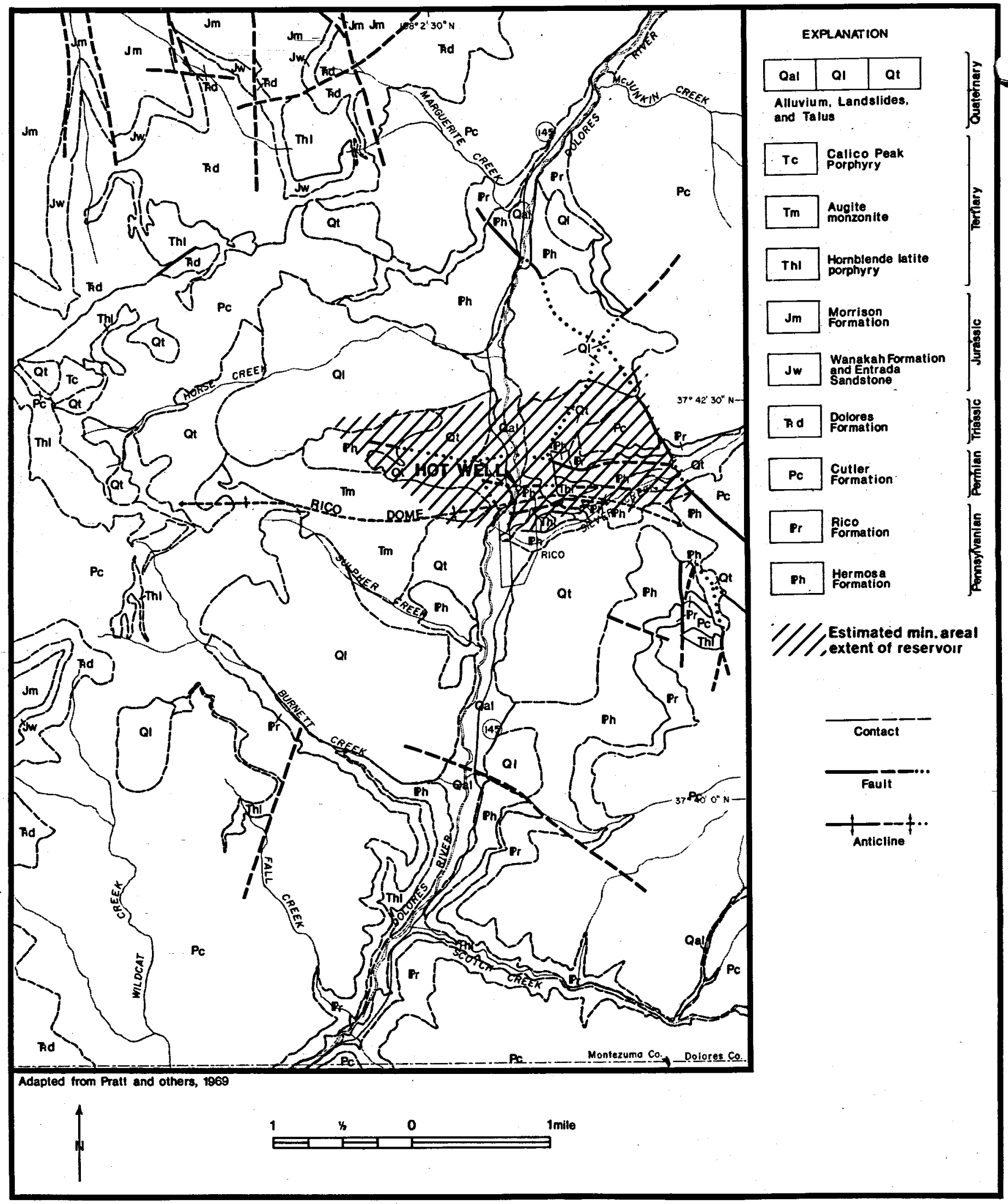

Figure 44.--Rico area, geology and estimated areal extent of the geothermal reservoir. 
Just to the north of Rico, Colorado, along the east bank of the Dolores River are, or Were, four core-drill holes that have been described as springs (Barrett and Pearl, 1978). These holes and their locations are as follows:

\section{LOCATION:}

Diamond Drill Hole: Latitude: $37^{\circ} 42^{\prime} 05^{\prime \prime N}$.;

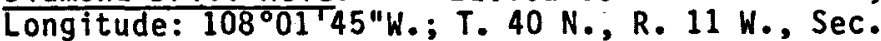
$\rightarrow$ N.M.P.M.; Dolores County; Rico $71 / 2$-minute topographic quadrangle map.

Big Geyser Warm Spring: Latitude: $37^{\circ} 42^{\prime} 00^{\prime \prime N}$.; Congitude: $108^{\circ} 01^{2} 44^{\prime \prime} W_{0}$; T. 40 N., R. 11 W., Sec.-, N.M.P.M.; Dolores County; Rico 7 1/2-minute topographic quadrangle map.

Geyser Warm Spring: Latitude: $37^{\circ} 42^{\prime} 02^{\prime \prime}$; Longitude: $108^{\circ} 011^{14}$ "W.; T. 40 N., R. 11 W., Sec.-, N.M.P.M.: Dolores County; Rico 7 1/2-minute topographic quadrangle map.

Little Spring: Latitude: $37^{\circ} 42^{\circ} 04^{\prime N}$.; Longitude: $108^{\circ} 01^{1} 44^{\prime \prime W}$.; T. 40 N., R. 11 W., Sec.-, N.M.P.M.; Dolores County; Rico 7 1/2-minute topographic quadrangle map.

GENERAL: All the above thermal waters are located along the east side of the dirt road leading into the Argentine Mine on the east side of the Dolores River 0.2 to 0.3 mile above the bridge across the Dolores River. While these are called "springs", they are actually drill holes. Two of the springs have geyser action, the waters from the Big Geyser attaining the greatest height of approximately 6 ft. These features may no longer exist by the time this report is published because of plans to plug the wells. All. the thermal waters are within 200 $y d$ of each other, and the waters are unused. The depths of these wells are unknown.

\section{GEOLOGY AND HYDROLOGY:}

Diamond Drill Hole: Temperature: $44^{\circ} \mathrm{C}$; Discharge: $15 \mathrm{gpm} ;$ Total Dissolved Solids: $2,250 \mathrm{mg} / 1$; and the waters are a calcium bicarbonate-sulfate type with a large concentration of manganese.

Big Geyser Warm Spring: Temperature: 34 to $36^{\circ} \mathrm{C}$; Discharge: 8-12 gpm; Total Dissolved Solids: 2,750 $\mathrm{mg} / 1$; and the waters are a calcium-bicarbonate type with large concentrations of iron and manganese.

Geyser Warm Spring: Temperature: $38^{\circ} \mathrm{C}$; Discharge: $14 \mathrm{gpm}$; Total Dissolved Solids: $2,790 \mathrm{mg} / 1$; and the waters are a calcium-bicarbonate type with large concentrations of iron and manganese.

Little Spring: Temperature: $38^{\circ} \mathrm{C}$; Discharge: 13 to $15 \mathrm{gpm}$; Total Dissolved Sol ids: $2,745 \mathrm{mg} / 1$ average; -nd the waters are a calcium bicarbonate-sulfate $b$ with large concentrations of iron and iranganese.
Geyser Warm Spring contained 38 picocuries/liter of Radium 226 , the highest of any thermal waters in Colorado, and 11 picocuries/liter of Radium228, the highest in Colorado.

The geological conditions in the Rico area are very complex for the area is cut by numerous faults and fractures (Fig. 44). The bedrock varies from Precambrian metamorphic rocks to Mississippian and younger sedimentary rocks. The hot water wells are located on the crest of the Rico Dome, a large anticlinal-type feature that extends from several miles west of Rico to the east of Rico.

No complete appraisal of the hydrogeological conditions of the area was possible, but the waters may represent deep circulation along some of the various fault systems in the area with the heating resulting from radioactive disintegration and residual heat from the magma chamber that supplied the Tertiary volcanic rocks.

Due to a high carbon dioxide content, the waters have a frothy appearance. This gas drives the water and gives the geyserlike activity to the waters.

GEOTHERMOMETER ANALYSES: Geothermometer models should be used with caution when applied to the Rico area because most of the assumptions inherent in their use are violated. Any geothermometer estimate for this group of springs is at best unreliable due to the ambiguous geochemistry of the waters (Barrett Pearl, 1978).

Silica solubility "and temperature relationships-suggest that temperature-dependent equilibration between the thermal water and amorphous silica controls the silica content of the thermal water. The amorphous silica geothermometer gives an estimated subsurface temperature of $22^{\circ} \mathrm{C}$ to $35^{\circ} \mathrm{C}$ (Table 3 ) which is below the surface temperature of the thermal water $\left(36^{\circ} \mathrm{C}\right.$. to $\left.44^{\circ} \mathrm{C}\right)$. This low estimate may be caused by shallow ground water dilution of the ascending thermal water.

The amorphous-silica mixing model yield a subsurface temperature estimate of $31^{\circ} \mathrm{C}$ to $39^{\circ} \mathrm{C}$ with a cold-water fraction of 1 to 19 percent of the total flow (Table 3) (Barrett and Pear1, 1978). Although the subsurface temperature estimate is below the surface temperature of the thermal water $\left(36^{\circ} \mathrm{C}\right.$ to $\left.44^{\circ} \mathrm{C}\right)$, it is within the expected margin of error.

The $\mathrm{Na}-\mathrm{K}$ and $\mathrm{Na}-\mathrm{K}-\mathrm{Ca}$ geothermometers yield subsurface temperature estimates of $185^{\circ} \mathrm{C}$ to $315^{\circ} \mathrm{C}$ and $17^{\circ} \mathrm{C}$ to $59^{\circ} \mathrm{C}$ respectively, (Table 3 ). The $\mathrm{Na}-\mathrm{K}$ geothermometer estimate is too high because the basic assumption of the model has been violated (Barrett and Pearl, 1978). Excluding the September 16,1975 , analysis of Rico Little Spring, the $\mathrm{Na}-\mathrm{K}-\mathrm{Ca}$ geothermometer yields temperature est imates of $56^{\circ} \mathrm{C}$ to $59^{\circ} \mathrm{C}$. The high magnesium content of the springs renders these results unreliable. 
RESOURCE ASSESSMENT: As shown on Figure 44, these thermal waters are Tocated in an area of intense faulting on the Rico Dome. It has been postulated that this system is fault controlled (Barrett \& Pearl, 1978). In drawing the boundaries of this system as much of the faulting in the area as possible was included. Therefore, the system as drawn is estimated to encompass an arf approximately $2.15 \mathrm{sq} \mathrm{mi}$ and contains $.1738 \mathrm{Q}$ 's heat energy at a maximum average temperature of $63^{\circ} \mathrm{C}$ (Table 2). 


\section{\#55 PINKERTON HOT SPRINGS}

Located approximately 14 miles north of Durango along U.S. Highway 550 are a group of springs known as the Pinkerton Hot Springs (Barrett and Pearl, 1978).

LOCATION: The location of the following springs were determined:

Spring A: Latitude: $37^{\circ} 26^{\prime} \cdot 50^{\prime \prime} \mathrm{N} .:$ Longitude: 107.48'T7"W.; T. 37 N., R. 9 W., Sec. $25 \mathrm{ab}$, N.M.P.M.; La Plata County; Hermosa 7-1/2 minute topographic quadrangle map.

Spring B: Latitude: $37^{\circ} 27^{\prime} 58^{\prime \prime} \mathrm{N}_{0}:$ Longitude: $107^{\circ} 48^{\top} 18$ "W.; T. 37 N., R. 9. W., Sec. 25 a, N.M.P.M.; La Plata County; Hermosa 7-1/2 minute topographic quadrangle map.

Mound Spring: Latitude: $37^{\circ} 27^{\prime} 07^{\prime \prime N}$.: Longitude: $107^{\circ} 48^{\prime} 20^{\prime \prime W} . ;$ T. 37 N., R. 9 W., Sec. 25 ba, N.M.P.M.; La Plata County; Hermosa 7-1/2 minute topographic quadrangle map.

Little Mound Spring: Latitude: $37^{\circ} 27^{\prime} 09^{\prime \prime N}$.; Longitude: $107^{\circ} 48121$ "W.; T. 37 N., R. 9 W., Sec. 25 ba, N.M.P.M.; La Plata County; Hermosa 7-1/2 minute topographic quadrangle map.

General: Spring $A$ is located just east of the highway right-of-way and to the south of the resort buildings. Spring B was located 900 to $1,200 \mathrm{ft}$ west of Spring $A$ in the trees and bushes. Mound Spring is located approximately $1,500 \mathrm{ft}$ northwest of Spring $A$. As the name implies, Mound Spring flows from the top of a large mound approximately $100 \mathrm{ft}$ above the road. Little Mound Spring is located several hundred ft north of. Mound Spring. The new section of U.S. 550 passes the base of Mound and Little Mound Springs. The construction of this new section of road has destroyed Spring B.

Geology and Hydrology: Spring A was sampled in the fall of 1975, January, 1976, and April 1976. The temperature remained a constant $32^{\circ} \mathrm{C}$, and its discharge was $54 \mathrm{gpm}$. The dissolved solids of the waters varied from a low of $3,700 \mathrm{mg} / 1$ to a high of $3,990 \mathrm{mg} / 1$, and the waters are a mixed sodium-calcium, chloride-bicarbonate type with a high concentration of iron.

Spring B was sampled only once. Its temperature was $33^{\circ} \mathrm{C}$ with a discharge of $20 \mathrm{gpm}$. The dissolved solids was not determined, but the field measurement of conductance was 6,000 micromhos. The waters are a sodium-bicarbonate type with a very high concentration of iron (Barrett and Pearl, 1978).

Mound Warm Spring: The waters of this spring have a temperature of $32^{\circ} \mathrm{C}$ and the discharge of the snring is $54 \mathrm{gpm}$. The waters contain approximately $0 \mathrm{mg} / 1$ of dissolved solids with a high iron cuitent.
Little Mound Spring: The waters of this spring were not sampled for complete chemical analysis of dissolved solids. Field measurements showed that the spring had a temperature of $26^{\circ} \mathrm{C}$, an estimated discharge of $2 \mathrm{gpm}, \mathrm{a} \mathrm{pH}$ of 7.0 , and a conductance of 5,500 micromhos.

Surrounding all four springs are large aprons of iron-rich sediments.

These springs are located on the south side of the La Plata Mountains and Coal Bank Hill, a pass in the La Plata Mountains. The waters emerge from colluvial and alluvial deposits overlying the Mississippian Leadville Limestone.

The La Plata Mountains and the San Juan Mounains, immediately to the east, were centers of extensive volcanic activity in middle Tertiary time. Although no volcanic rocks are found near these springs, they occur only a few miles to the north. While not shown on the accompanying geologic map (Fig. 45), the Leadville Limestone appears to be faulted in the vicinity of the springs. Moyer and others (1961) state that the waters emerge from a fault transverse to the valley. Any explanation of the occurrence of these thermal waters must explain the high concentration of dissolved iron and evaporite mineral matter in the waters. Kilgore and Clark (1961, p. 235) have shown that a thin section of early Paleozoic limestones and sandstones underlies the Pinkerton Hot Springs, none of which contain large amounts of readily soluble minerals, especially iron. However, the overlying red sandstones, shales, siltstones of the Hermosa Group do. In addition, formations within the Hermosa group contain large amounts of evaporite minerals. Contact of the thermal waters with these units would explain the origin of the mineral matter in the thermal waters.

Reiter (1975) has shown this part of western Colorado to have a heat flow between 2.0 and 2.5 heat flow units. The source of the heat is unknown but may be related to the volcanic rocks found in the La Plata and San Juan Mountains. Recharge of the thermal water is believed to occur via deep circulation along fault zones from the La Plata Mountains.

GEOTHERMOMETER ANALYSIS:

Quartz-silica geothermometer yields an estimated temperature of $78^{\circ} \mathrm{C}$ for Spring $A$ and Mound Spring (Barrett and Pearl, 1978). The quartz mixing model yields an estimated subsurface temperature of $127^{\circ} \mathrm{C}$ to $133^{\circ} \mathrm{C}$ with a cold-water fraction of 81 to 82 percent. A temperature of $139^{\circ} \mathrm{C}$ with a cold-water fraction of 84 percent was determined for Mound Spring (Table $3)$. These values are within the range of values that could result from normal analytical error. The $\mathrm{Na-K}$ geothermometer yields a subsurface temperature estimate of $231{ }^{\circ} \mathrm{C}$ to $234^{\circ} \mathrm{C}$ for Spring $A$, and $234^{\circ} \mathrm{C}$ to $235^{\circ} \mathrm{C}$ for Mound Spring. The $\mathrm{Na}-\mathrm{K}-\mathrm{Ca}$ geothermometer yields an estimated 


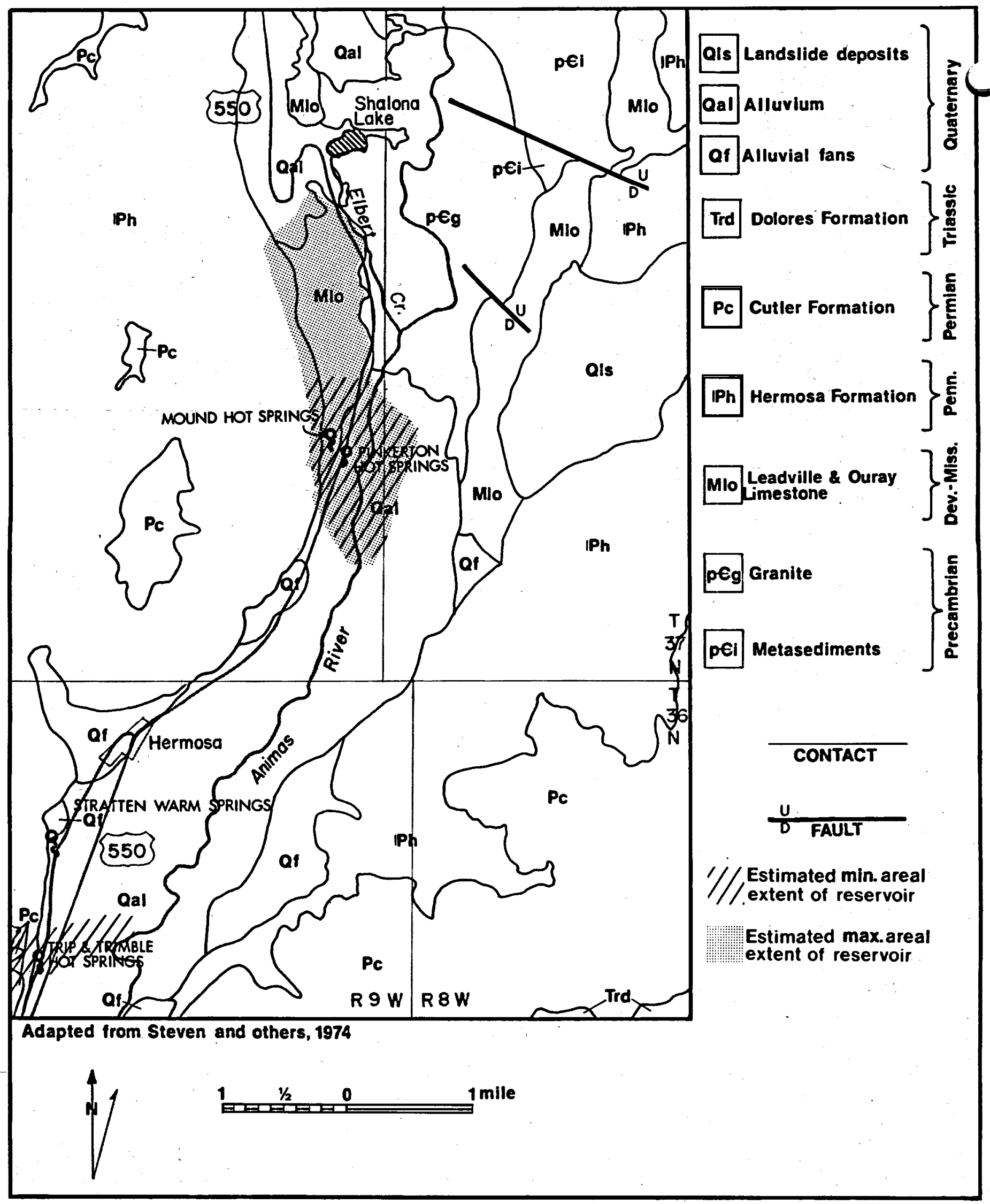

Figure 45.--Pinkerton, Mound, Tripp, Trible and Stratten Springs area, geology and estimiated areal extent of the geothermal reservoirs. 
temperature of $202^{\circ} \mathrm{C}$ to $206^{\circ} \mathrm{C}$ for spring $\mathrm{A}$ and $76^{\circ} \mathrm{C}$ to $207^{\circ} \mathrm{C}$ for Mound Spring. Barrett and Pearl 78) noted that the $\mathrm{Na}-\mathrm{K}$ estimated temperature is too high because the basic assumption of the model was violated. The large travertine and calcium carbonate deposits near the hot springs suggest that both the $\mathrm{Na}-\mathrm{K}$ and $\mathrm{Na}-\mathrm{K}-\mathrm{Ca}$ geothermometer est imates are too high (Barrett and Pearl, 1978).

Conclusion: Consideration of the mixing model and silica geothermometer results and mixing model precision suggests subsurface temperatures between $75^{\circ}$ and $125^{\circ} \mathrm{C}$ (Table 3 ).

RESOURCE ASSESSMENT: Barrett \& Pearl (1978) noted that these springs are associated.with faulted Leadville Limestone. As the Leadville Limestone is a permeable cavernous unit and appears to contain large amounts of water, the boundaries of this system were purposely drawn to include a large area to the south and east of the springs. A second estimate of the reservoirs extent was made. This estimate extended the reservoir to the north and included all the Leadville outcrop to the south of the spring (Figure 45 ).

The estimated size of the system varied from less than $1.0 \mathrm{sq} \mathrm{mi}$ to just over $2 \mathrm{sq} \mathrm{mi}$. The energy contained in the system varied from .0099 $Q^{\prime}$ s to $.0209 Q^{\prime}$ s at an average maximum temperature of $50^{\circ} \mathrm{C}($ Table 2$)$. 


\title{
\#56 TRIPP AND TRIMBLE WARM SPRINGS
}

\author{
\#56 TRMBLE HOT SPRING
}

LOCATION: Latitude: $37^{\circ} 23^{\prime} 28^{\prime \prime N}$.; Longitude: $107^{\circ} 50^{\prime} 52^{\prime \prime W}$.; T. 36 N., R. 9 W., Sec. 15 bb, N.M.P.M.; La Plata County; Hermosa 7 1/2-minute topographic quadrangle map.

GENERAL: Trimble Hot Spring is located approximately 9.25 miles north of Durango just off U.S. Highway 550. At the present time the spring is unused and just barely flows. In the past this spring fed the large swimming pool located to the south. The spring is inside a small rock house.

GEOLOGY AND HYDROLOGY: This spring had a temperature of $36^{\circ} \mathrm{C}$ and a discharge of less than one gpm. The waters contained $3,340 \mathrm{mg} / 1$ of dissolved mineral matter and are a calcium sulfate type.

The waters, although issuing from colluvial deposits at the base of the cliff, are associated with the underlying red beds of the Paradox Formation (Fig. 45).

Moyer and others (1961) have described a northeast-trending fault, downthrown on the northwest side, crossing the valley near the springs. They state that the springs emerge along this fault zone. Kilgore and Clark (1961) show this and other faults in the vicinity reaching to basement rocks. The origin of these thermal waters is unknown but may result from deep circulation and updip flow along faults in the San Juan basin.

\section{\#56 TRIPP HOT SPRING}

LOCATION: Latitude: $37^{\circ} 23^{\circ} 30^{\prime N}$.; Longitude: $107^{\circ} 50^{\prime} 52$ "W.; T. 36 N., R. 9 W., Sec. 10 cc, N.M.P.M.; La Plata County; Hermosa 7 1/2-minute topographic quadrangle map.

GENERAL: This spring is located less than $200 \mathrm{ft}$ north of the Trimble Hot Spring, approximately 9.25 miles north of Durango off U.S. Highway 550 . The spring is located in the big tin building behind

GEOTHERMOMETER ANALYSES: Geothermometer models must be used with caution when applied to Tripp and Trimble warm springs because most of the assumptions inherent in their use are violated. However, the subsurface temperature is probably between $45^{\circ} \mathrm{C}$ and $70^{\circ} \mathrm{C}$ (Table 3 ) (Barrett and Pearl, 1978).

The silica content of these springs does not approach the solubilities of amorphous silica, chalcedony, cristobalite, or quartz. Therefore, application of any of these silica geothermometers will yield unreliable results. The amorphous silica solubility at the warm springs surface temperature $\left(36^{\circ} \mathrm{C}\right.$ to $\left.44^{\circ} \mathrm{C}\right), 143$ to $164 \mathrm{mg} / 1$, is much higher than the silica content of the thermal water (69 to $72 \mathrm{mg} / 1)$. This discrepancy may be caused by mixing of the thermal water and relatively dilute groundwater.

The amorphous-silica mixing model yields a subsurface temperature estimate of $30^{\circ} \mathrm{C}$ to $40^{\circ} \mathrm{C}$ with a cold-water fraction of 39 to 47 percent of the spring flow (Table 3 ). the house. The spring was sampled from a concrete-lined trough in the metal building.

GEOLOGY AND HYDROLOGY: Temperature: $44^{\circ} \mathrm{C}$; Discharge: not determined; Total Dissolved Solids: $3,240 \mathrm{mg} / 1$; Calcium-sodium sulfate type.

Like the Trimble Hot Spring waters, these waters come from colluvial deposits overlying the red beds of the Paradox Formation.

The $\mathrm{Na}-\mathrm{K}$ and $\mathrm{Na}-\mathrm{K}-\mathrm{Ca}$ geothermometers yield subsurface temperature estimates of $197^{\circ} \mathrm{C}$ to $198^{\circ} \mathrm{C}$ and $97^{\circ} \mathrm{C}$ to $99^{\circ} \mathrm{C}$, respectively (Table 3 ). The $\mathrm{Na}-\mathrm{K}$ geothermometer estimate is too high because the basic assumption of the model has been violated (Barrett and Pearl, 1978). The low surface temperature and flow (less than $1 \mathrm{gpm}$ ) and the lack of substantiation of such high subsurface temperatures by the other geothermometers suggest that both the $\mathrm{Na}-\mathrm{K}$ and $\mathrm{Na}-\mathrm{K}-\mathrm{Ca}$ estimates are unreliable.

RESOURCE ASSESSMENT: Barrett \& Pearl (1978) in describing the geotogic contols of this spring, reported that the springs are located on an unmapped northeast trending fault. They also stated that the waters are associated with the red sedimentary Cutler Formation.

In attempting to draw the boundaries of this system, the boundaries were drawn to try and encompass the northeast trending fault (Fig. 45). As drawn, the area encompasses approximately 1.0 sa mi. If this is accurate, the system could cont some .0357 Q's of heat energy at an avera temperature of $58^{\circ} \mathrm{C}$ (Table 2). 


\section{\#57 STRATTEN WARM SPRING}

LOCATION: Latitude: $37^{\circ} 24^{\prime} 23^{\prime \prime N} . ;$. Longitude; $107^{\circ} 50^{\prime} 37^{\prime \prime}$.; T. 36 N., R. $9 W_{\text {. }} \operatorname{Sec} 10 \mathrm{bab}$, N.M.P.M.; La Plata County, Hermosa 7 1/2 minute topographic quadrangle map.

GENERAL: This unused spring is located approximately one mile north of Tripp Warm Spring on the west side of the road at the base of the hill.

GEOLOGY AND HYDROLOGY: The spring has a temperature of $28^{\circ} \mathrm{C}$ and a discharge of approximately $10 \mathrm{gpm}$. The waters have a pH of 6.8 and a conductivity of 1950 micromohs. This spring was located in the fall of 1978 and has not yet been sampled or the water analyzed for contained mineral matter.
A complete geologic appraisal of this area has not yet been done. While the waters, issue from colluvial deposits at the base of the cliff they are associated with the underlying red beds of the Paradox Formation (Fig. 45).

GEOTHERMOMETER ANALYSIS: As these waters have not yet been analyzed for contained mineral matter it was not possible .to calculate the estimated reservoir temperatures.

RESOURCE ASSESSMENT: No attempt was made to estimate the amount of energy contained in this system. 


\section{\#58 PIEDRA RIVER SPRING}

LOCATION: Latitude: $37^{\circ} 18^{\prime} 14^{\prime \prime}$.; $\quad$ Longitude: Unsurveyed T. 35 N., R. 4 W. Sec. 19, N.M.P.M., Archuleta County, Devil Mountain $71 / 2$ minute topographic quadrangle map.

GENERAL: These unused springs extend north approximately 30 yd along the east bank of the Piedra River from Coffee Creek. The springs may be reached from U.S. 160 by the dirt road that runs along the east side of the Piedra River. Go approximately 6.7 miles to the intersection of Monument Park Road and Sheep Creek Trail. Take the trail downward to the river and follow the trail along the east bank for approximately one mile to Coffee Creek. At this point the valley floor widens into a little meadow. The springs are located along the river. If the river is at high stage the springs may not be visiable for they are located along the side of the river channel.

GEOLOGY AND HYDROLOGY: These springs have not yet been sampled and analyzed for contained mineral matter. Field measurements in the fall of 1978 determined that the spring waters have a $\mathrm{pH}$ of 6.5 , a conductivity of 2650 micromohs, and a temperature of $42^{\circ} \mathrm{C}$, and a discharge of approximately $50 \mathrm{gpm}$.

No complete geologic appraisal of the area surrounding these springs has yet been made by the author. Reconnaissance mapping shows that the springs emerge from alluvial deposits overlying the Leadville Limestone. The area. is structurally complex and Tertiary age extrusive volcanic rocks are found a few miles to the north.

GEOTHERMOMETER ANALYSIS: As the dissolved mineral matter contained in these waters has not yet been determined no attempt has been made to determine the estimated reservoir temperatures.

RESOURCE ASSESSMENT: The author has not yet attempted to determine the amount of energy contained in this system. 


\section{OTHER AREAS}

Not shown on Figure 1 are a number of supposedly thermal springs and wells which have been called to the authors attention. As they have not yet been located or measured by representives from the Colorado Geological survey they will not be described here. Information about these springs and wells, which are described in Tables 4 and 5 is here presented for informational purposes only.

\section{SUMMARY}

Colorado's geothermal resource potential is expressed in the over 160 thermal springs and wells (temperatures in excess of $20^{\circ} \mathrm{C}$ ) found throughout the western one-half of the state. While these springs and wells are found in a variety of geological environments, the majority of them are associated with the Rio Grande Rift of the San Luis Valley and Upper Arkansas Valleys, and with the San Juan and La Plata Mountains of southwestern Colorado.

To aid in appraising the hydrothermal resources of Colorado, geothermometer models were utilized to estimate the subsurface reservoir temperatures of the various thermal areas. The models used were: Silica, Mixing Model I and II, $\mathrm{Na}-\mathrm{K}$, and Na-K-Ca. Probable subsurface temperatures range from a low of $20^{\circ} \mathrm{C}$ at Dexter Warm Spring in the southern San Luis Valley to high of over $200^{\circ} \mathrm{C}$ at both Cottonwood Hot Springs and Mount Princeton Hot Springs areas.

Using data presented by Barrett and Pearl (1978), the areal extent of each thermal system was estimated and the amount of heat contained in the system calculated. These estimates showed that the total amount of heat contained in the hydrothermal systems in Colorado ranged from 4.8782 Quads to 13.2386 Quads. 


\section{TABLE 1}

\section{ALPHABETICAL LIST OF THERMAL SPRINGS AND WELLS IN COLORADO}

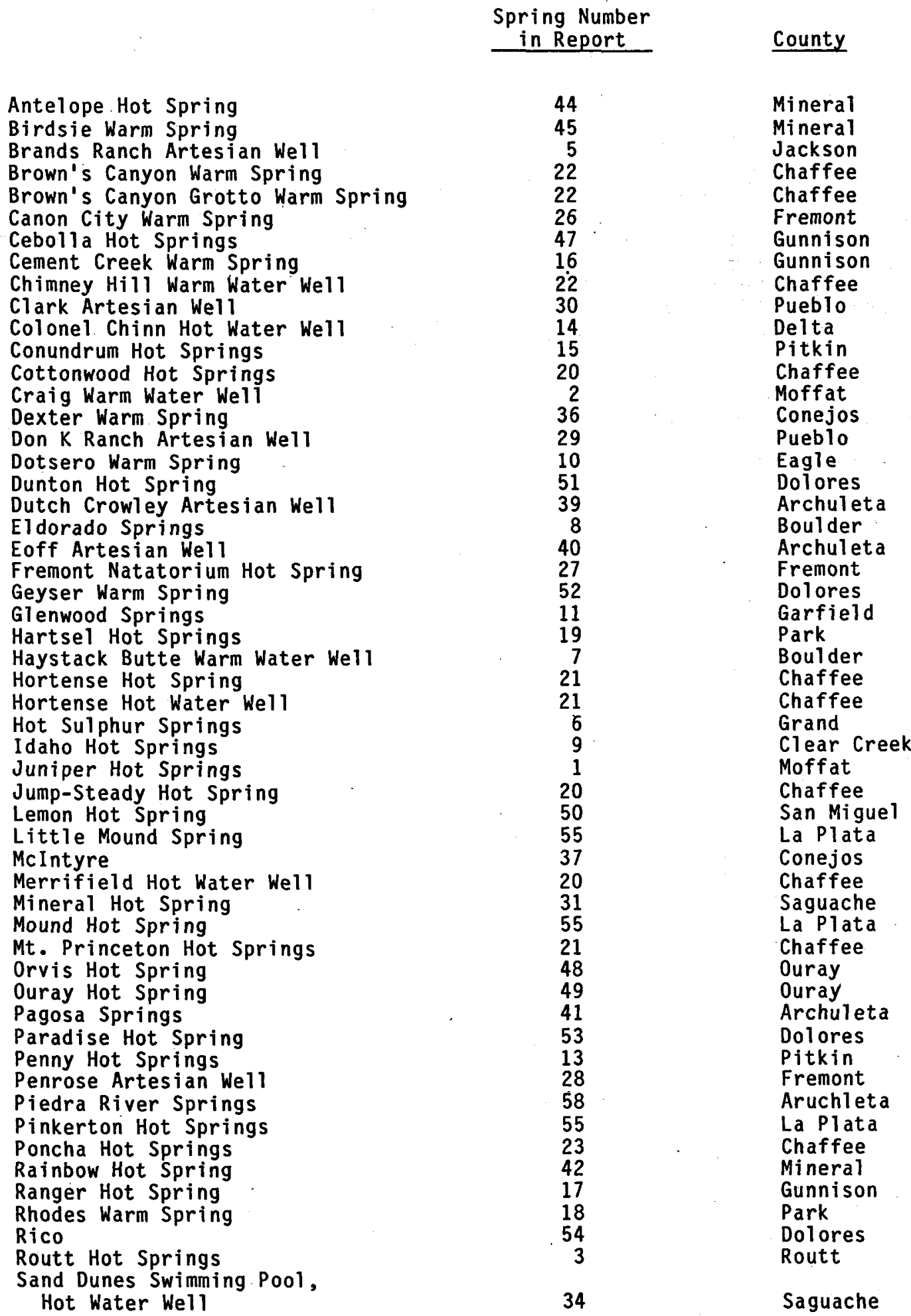




\section{TABLE 1 (Cont.)}

in Report

Shaws Warm Spring

South Canyon Hot Spring

Splashland Hot Water Well

Steamboat Springs

Stinking Springs

Stratten Warm Spring

Swissvale Warm Spring

Trimble Hot Spring

Tripp Hot Spring

Valley View Hot Springs

Wagon Wheel Gap Hot Springs

Waunita Hot Springs, Upper and Lower

Well sville Warm Spring

Woolmington Warm Water Well

Wright Water Wells

Young Life Hot Water Well
33

12

35

4

38

57

25

56

56

32

43

46

24

21

21

21
County

Saguache Garfield

Al amosa

Routt

Archuleta

La Pilata

Fremont

La Plata

La Plata

Saguache

Mineral

Gunnis on

Fremont

Chaffee

Chaffee

Chaffee 


\section{TABLE 2}

\section{ASSESSMENT OF HYDROTHERMAL RESOURCES IN COLORADO}

(Adapted from Coe, 1978)

\begin{tabular}{|c|c|c|c|c|c|c|}
\hline \multirow{2}{*}{$\begin{array}{l}\text { Thermal } \\
\text { Spring Areas }\end{array}$} & \multirow{2}{*}{\multicolumn{2}{|c|}{$\begin{array}{l}\text { Areal } \\
\text { Extent } \\
\left(m i^{2}\right)\end{array}$}} & \multirow[b]{2}{*}{$\begin{array}{l}\text { Thickness } \\
\text { (ft.) }\end{array}$} & \multirow[b]{2}{*}{$\begin{array}{l}\text { Temp. } \\
\left({ }^{\circ} \mathrm{C}\right)\end{array}$} & \multicolumn{2}{|c|}{$\begin{array}{c}\text { Estimated Total } \\
\text { Btu's }\end{array}$} \\
\hline & & & & & $\begin{array}{l}\text { Propable } \\
\text { (1015) }\end{array}$ & $\begin{array}{l}\text { Feasible } \\
(1015)\end{array}$ \\
\hline Juniper & 1 & 1.00 & $200(S)$ & 63 & .0163 & .0163 \\
\hline Craig & 2 & $\begin{array}{l}1.00 \\
12.0\end{array}$ & $\begin{array}{l}500(U) \\
500(U)\end{array}$ & $\begin{array}{l}55 \\
55\end{array}$ & .0329 & .395 \\
\hline Routt & 3 & $\begin{array}{l}0.5 \\
0.75\end{array}$ & $\begin{array}{l}1000(\mathrm{~F}) \\
1000(\mathrm{~F})\end{array}$ & $\begin{array}{l}138 \\
138\end{array}$ & .1110 &.$---\bar{~}$ \\
\hline Steamboat & 4 & 0.52 & $1000(F)$ & 70 & .0487 & .0487 \\
\hline Brand's Ranch & 5 & $\begin{array}{l}0.36 \\
1.5\end{array}$ & $\begin{array}{l}200(S) \\
200(S)\end{array}$ & $\begin{array}{l}49 \\
49\end{array}$ & .0039 & .0164 \\
\hline Hot Sulphur & 6 & 1.35 & $500(U)$ & 75 & .0698 & .0698 \\
\hline Haystack Butte & 7 & $\begin{array}{l}0.54 \\
1.50\end{array}$ & $\begin{array}{l}300(s) \\
300(s)\end{array}$ & $\begin{array}{l}40 \\
40\end{array}$ & .0061 &.$\overline{0169}$ \\
\hline Eldorado & 8 & 0.52 & $1000(F)$ & 35 & .0147 & .0147 \\
\hline Idaho & 9 & 1.52 & $1000(F)$ & 80 & .1714 & .1714 \\
\hline Dotsero & 10 & 0.50 & $250(s)$ & 39 & .0045 & .0045 \\
\hline Glenwood & 11 & $\begin{array}{l}1.32 \\
0.50\end{array}$ & $\begin{array}{l}250(S) \\
250(S)\end{array}$ & $\begin{array}{l}65 \\
65\end{array}$ & $(.0279)$ & $\begin{array}{l}.0279 \\
(.0106)\end{array}$ \\
\hline South Canyon & 12 & 0.1 & $200(5)$ & 75 & .0021 & .0021 \\
\hline Penny & 13 & $\begin{array}{l}1.61 \\
4.7\end{array}$ & $\begin{array}{l}1000(\mathrm{~F}) \\
1000(\mathrm{~F})\end{array}$ & $\begin{array}{l}75 \\
75\end{array}$ & .1664 &.--- \\
\hline Colonel Chinn & 14 & 1.55 & $200(s)$ & 51 & .0181 & .0181 \\
\hline Conundrum & 15 & 0.45 & $200(s)$ & 45 & .0042 & .0042 \\
\hline Cement Creek & 16 & $\begin{array}{l}0.28 \\
1.40\end{array}$ & $\begin{array}{l}1000(F) \\
1000(F)\end{array}$ & $\begin{array}{l}45 \\
45\end{array}$ & .0132 & .0658 \\
\hline Ranger & 17 & $\begin{array}{l}0.30 \\
0.88\end{array}$ & $\begin{array}{l}150(s) \\
150\end{array}$ & $\begin{array}{l}45 \\
45\end{array}$ & .0021 & .0062 \\
\hline Rhodes & 18 & $\begin{array}{l}1.53 \\
7.1\end{array}$ & $\begin{array}{l}1000(F) \\
1000(F)\end{array}$ & $\begin{array}{l}35 \\
35\end{array}$ & .0432 & .2003 \\
\hline Hartsel & 19 & 1.00 & $500(U)$ & 70 & .0470 & .0470 \\
\hline Cottonwood Cre & eek 20 & $\begin{array}{l}1.38 \\
4.14\end{array}$ & $\begin{array}{l}1000\langle F\rangle \\
1000\langle F\rangle\end{array}$ & $\begin{array}{l}170 \\
170\end{array}$ & .3894 & $\overline{1.1672}$ \\
\hline
\end{tabular}


TABLE 2 (Cont.)

\begin{tabular}{|c|c|c|c|c|c|c|}
\hline $\begin{array}{c}\text { Thermal } \\
\text { Spring Areas } \\
\end{array}$ & & $\begin{array}{l}\text { Areal } \\
\text { Extent } \\
\left(m i^{2}\right) \\
\end{array}$ & $\begin{array}{l}\text { Thickness } \\
\text { (ft.) }\end{array}$ & $\begin{array}{l}\text { Temp. } \\
\left({ }^{\circ} \mathrm{C}\right) \\
\end{array}$ & $\begin{array}{l}\text { Estimatec } \\
\text { Btt } \\
\text { Probable } \\
\text { (1015) }\end{array}$ & $\begin{array}{l}\text { Feasible } \\
(1015)\end{array}$ \\
\hline Mt. Princeton & n 21 & $\begin{array}{c}3.14 \\
4.0 \\
10.0\end{array}$ & $\left.\begin{array}{l}1000(F \\
1000 \\
1.000 \\
F \\
S\end{array}\right)$ & $\begin{array}{l}200 \\
200 \\
160\end{array}$ & $\begin{array}{r}1.0623 \\
\hdashline-.-\end{array}$ & $\begin{array}{l}(\overrightarrow{3} . \overrightarrow{3544}) \\
2.6314\end{array}$ \\
\hline Browns Canyon & n 22 & $\begin{array}{l}1.50 \\
3.23\end{array}$ & $\begin{array}{l}1000(F) \\
1000(F)\end{array}$ & $\begin{array}{l}100 \\
100\end{array}$ & .2256 &.$---\overline{-}$ \\
\hline Poncha & 23 & $\begin{array}{l}0.60 \\
5.07\end{array}$ & $\begin{array}{l}1000(F) \\
1000(F)\end{array}$ & $\begin{array}{l}145 \\
145\end{array}$ & .1410 & 1.1911 \\
\hline Wellsvilie/SW & $\begin{array}{l}\text { wissvale } \\
24 / 25\end{array}$ & $\begin{array}{l}0.94 \\
1.66\end{array}$ & $\begin{array}{l}240(s) \\
240(s)\end{array}$ & $\begin{array}{l}40 \\
40\end{array}$ & .0085 & .0150 \\
\hline Canon City & 26 & 0.50 & $100(S)$ & 50 & .0028 & .0028 \\
\hline Freemont Nata & atorium 27 & 71.0 & $220(s)$ & 43 & .0095 & .0095 \\
\hline Florence & 28 & $\begin{array}{l}1.0 \\
5.2\end{array}$ & $\begin{array}{l}200(s) \\
200(s)\end{array}$ & $\begin{array}{l}42 \\
42\end{array}$ & .0083 & .0430 \\
\hline Don K. Ranch & 29 & 1.5 & $500(U)$ & 45 & .0353 & .0353 \\
\hline Clark Well & 30 & 1.1 & $200(s)$ & 40 & .0083 & .0083 \\
\hline Mineral & 31 & $\begin{array}{l}10.1 \\
32.0\end{array}$ & $\begin{array}{l}1000(F) \\
1000(F)\end{array}$ & $\begin{array}{l}70 \\
70\end{array}$ & .9492 & 3.007 \\
\hline Valley View & 32 & 1.0 & $1000(F)$ & 50 & .0564 & .0564 \\
\hline Shaw's & 33 & 0.63 & $500(U)$ & 45 & .0148 & .0148 \\
\hline Sand Dunes & 34 & 1.5 & $1000(S)$ & 75 & .1551 & .1551 \\
\hline Splashl and . & 35 & 1.5 & $1000(s)$ & 75 & .1551 & .1551 \\
\hline Dexter/McInty & yre $36 / 37$ & 1.2 & $1000(F)$ & 35 & .0339 & .0339 \\
\hline Stinking/Dutc & $\begin{array}{l}\text { ch Crowley } \\
38 / 39\end{array}$ & $\begin{array}{l}1.52 \\
3.66\end{array}$ & $\begin{array}{l}200(s) \\
200(s)\end{array}$ & $\begin{array}{l}65 \\
65\end{array}$ & .0257 & .0620 \\
\hline Eoff Well & 40 & 1.5 & $200(s)$ & 50 & .0169 & .0169 \\
\hline Pagosa & 41 & 1.00 & $200(s)$ & 80 & .0226 & .0226 \\
\hline Rainbow & 42 & $\begin{array}{l}1.00 \\
2.0\end{array}$ & $1000\{\mathrm{~F}\}$ & $\begin{array}{l}45 \\
45\end{array}$ & .0470 & .0940 \\
\hline Wagonwheel Ga & ap $43^{-}$ & $\begin{array}{r}0.70 \\
16.00\end{array}$ & $\begin{array}{l}500(U) \\
500(U)\end{array}$ & $\begin{array}{l}115 \\
115\end{array}$ & .0625 & 1.4285 \\
\hline Antel ope/Bird & $\begin{array}{l}\text { dsie } \\
4 / 45\end{array}$ & $\begin{array}{l}0.50 \\
3.90\end{array}$ & $\begin{array}{l}500(U) \\
500(U)\end{array}$ & $\begin{array}{l}44 \\
44\end{array}$ & .0113 & .0880 \\
\hline Waunita & 46 & 1.4 & $200(s)$ & 135 & .0606 & .0606 \\
\hline Cebolla & 47 & 1.28 & $500(U)$ & 60 & .0481 & .0481 \\
\hline
\end{tabular}


TABLE 2 (Cont.)

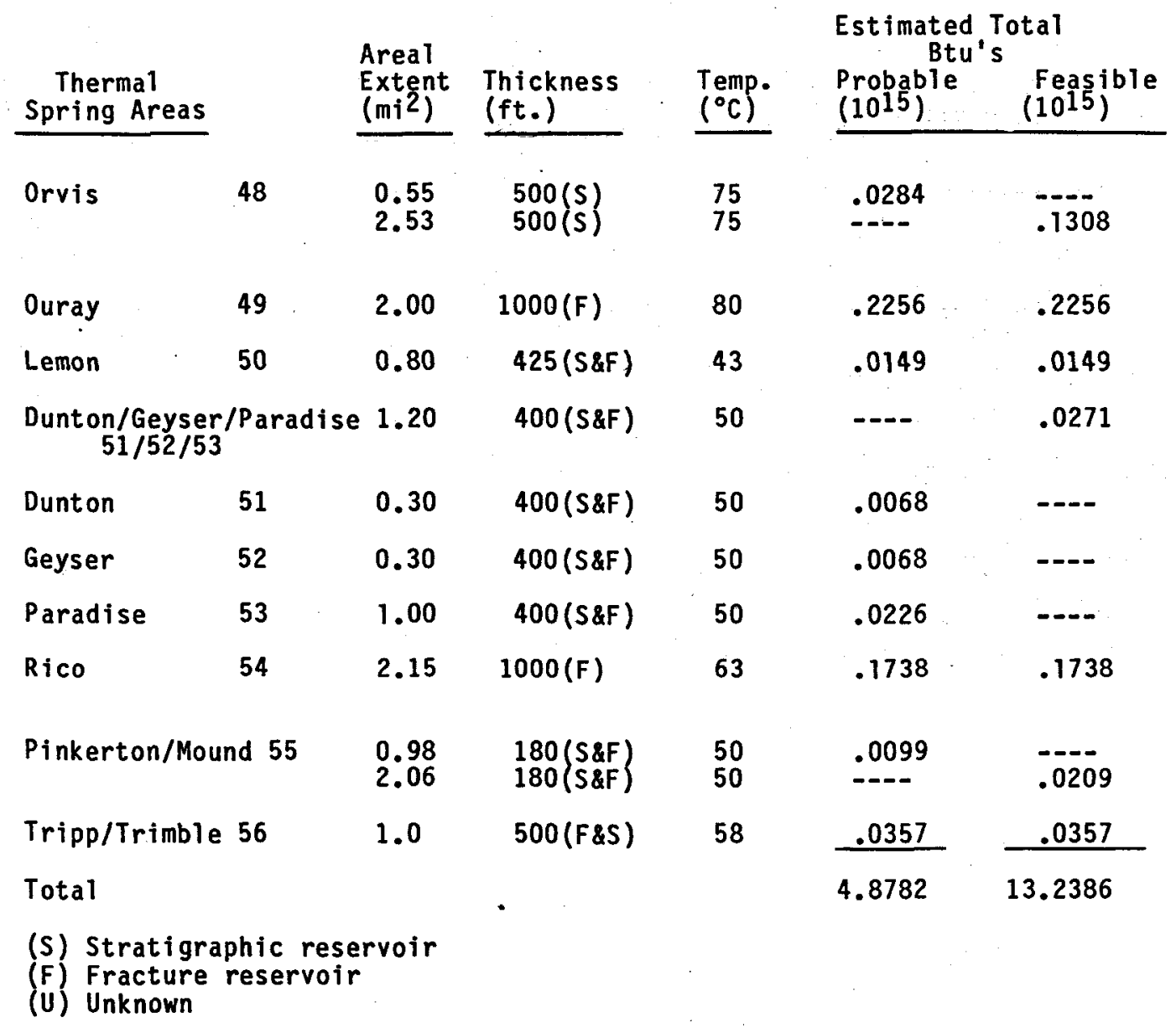




\section{TABLE 3}

\section{ESTIMATED RESERVOIR TEMPERATURES $\left({ }^{\circ} \mathrm{C}\right)$ AND GEOCHEMICAL DATA}

(Adapted from Barrett and Pearl, 1978)

Geothermometer Models

$\begin{array}{ll}q=\text { quartz } & c=\text { chal cedony } \\ a=\text { amorphous } & c r=\text { cristobalite }\end{array}$

\begin{tabular}{|c|c|c|c|c|c|c|c|c|c|c|}
\hline Hot Spring & $\begin{array}{l}\text { pring } \\
\text { umber } \\
\end{array}$ & $\begin{array}{c}\text { Date } \\
\text { Sampled }\end{array}$ & $\begin{array}{l}\text { Silica } \\
\text { G.T. }\end{array}$ & $\begin{array}{c}\text { Mixi } \\
\text { Mod } \\
\text { T. }\end{array}$ & $\%$ & $\begin{array}{l}\mathrm{Na}-\mathrm{K} \\
\mathrm{G.T} .\end{array}$ & $\begin{array}{l}\mathrm{Na}-\mathrm{K}-\mathrm{Ca} \\
\text { G.T. } \\
\end{array}$ & $\begin{array}{c}\text { Most } \\
\text { Likely } \\
\text { Sub. Temp. } \\
\end{array}$ & $\begin{array}{c}\text { Discharge } \\
\text { gpm. }\end{array}$ & $\begin{array}{l}\text { T.D.S. } \\
\underline{\mathrm{mg} / \mathrm{l}}\end{array}$ \\
\hline Antelope W.S & 44 & $\begin{array}{r}8 / 75 \\
10 / 75\end{array}$ & 41 & 49 & $36 \mathrm{cr}$ & 83 & 35 & $35-52$ & $\begin{array}{l}3 \mathrm{E} \\
3 \mathrm{E}\end{array}$ & $\begin{array}{l}151 \\
150\end{array}$ \\
\hline Birdsie W.S. & 45 & $8 / 76$ & $52 \mathrm{cr}$ & 91 & $70 \mathrm{cr}$ & 102 & 36 & $35-52$ & 15 & 168 \\
\hline Brands Ranch & 5 & $7 / 76$ & $42 c$ & 43 & $1 \mathrm{c}$ & 199 & 171 & $42-55$ & $80 \mathrm{E}$ & 262 \\
\hline Brown's Grotto W.S. & 22 & $6 / 76$ & $49 \mathrm{cr}$ & 129 & $87 \mathrm{cr}$ & 123 & 89 & $50-100$ & $3 \mathrm{E}$ & 494 \\
\hline Canon City H.S. & 26 & $\begin{array}{l}9 / 75 \\
1 / 76 \\
4 / 76\end{array}$ & $\begin{array}{ll}35 & c \\
34 & c \\
34 & c\end{array}$ & $\begin{array}{l}40 \\
38 \\
38\end{array}$ & 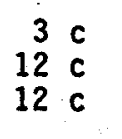 & $\begin{array}{l}187 \\
187 \\
188 \\
-\end{array}$ & $\begin{array}{l}70 \\
68 \\
72 \\
-\end{array}$ & $-\overline{-}$ & $\begin{array}{l}5 \\
1 \\
2\end{array}$ & $\begin{array}{l}1,230 \\
1,220 \\
1,210\end{array}$ \\
\hline$\frac{\text { Cebolla Hot Springs }}{\text { Spring "A" }}$ & 47 & $\begin{array}{r}7 / 75 \\
10 / 75 \\
1 / 76 \\
4 / 76\end{array}$ & $\begin{array}{l}71 \mathrm{cr} \\
65 \mathrm{cr} \\
78 \mathrm{cr} \\
82 \mathrm{cr}\end{array}$ & $\begin{array}{l}125 \\
105 \\
163 \\
185\end{array}$ & $\begin{array}{l}72 \mathrm{cr} \\
66 \mathrm{cr} \\
80 \mathrm{cr} \\
83 \mathrm{cr}\end{array}$ & $\begin{array}{l}278 \\
248 \\
238 \\
252\end{array}$ & $\begin{array}{l}216 \\
215 \\
209 \\
220\end{array}$ & -- & $\begin{array}{r}-- \\
3 \\
3 \\
3\end{array}$ & $\begin{array}{l}1,450 \\
1,440 \\
1,470 \\
1,450\end{array}$ \\
\hline Spring "B" & 47 & $7 / 75$ & $73 \mathrm{cr}$ & 145 & $78 \mathrm{cr}$ & 249 & 217 & & -- & 1,460 \\
\hline Spring "C" & 47 & $7 / 75$ & $74 \mathrm{cr}$ & 143 & $76 \mathrm{cr}$ & 250 & 217 & -- & -- & 1,460 \\
\hline Cement Ck. W.S. & 16 & $\begin{array}{r}7 / 75 \\
10 / 75 \\
1 / 76 \\
4 / 76\end{array}$ & $\begin{array}{ll}30 & c \\
25 & c \\
25 & c \\
28 & c\end{array}$ & $\begin{array}{l}53 \\
27 \\
27 \\
29\end{array}$ & $\begin{array}{rl}61 & c \\
0 & c \\
0 & c \\
6 & c\end{array}$ & $\begin{array}{l}232 \\
225 \\
225 \\
238 \\
-\end{array}$ & $\begin{array}{l}45 \\
48 \\
46 \\
49 \\
-\end{array}$ & $30-60$ & $\begin{array}{l}-- \\
80 \\
60 \\
60\end{array}$ & $\begin{array}{l}401 \\
389 \\
398 \\
382\end{array}$ \\
\hline \multicolumn{11}{|c|}{$\frac{\text { Chalk Creek H.S. Area: }}{\text { Mt. Princeton }}$} \\
\hline Mhe rrificecon & 21 & $\begin{array}{r}7 / 75 \\
10 / 75 \\
1 / 76 \\
4 / 76\end{array}$ & $\begin{array}{l}110 q \\
1089 \\
1059 \\
127 q\end{array}$ & $\begin{array}{l}194 \\
190 \\
186 \\
236\end{array}$ & $\begin{array}{ll}78 & q \\
77 & q \\
77 & q \\
81 & q\end{array}$ & $\begin{array}{l}149 \\
148 \\
151 \\
150\end{array}$ & $\begin{array}{l}56 \\
58 \\
58 \\
59\end{array}$ & $150-200$ & $\begin{array}{l}-8 \\
18 \\
20 \\
23\end{array}$ & $\begin{array}{l}245 \\
248 \\
244 \\
248\end{array}$ \\
\hline H.S. "F" & 21 & $7 / 75$ & $107 q$ & 201 & $81 \cdot q$ & 150 & 51 & $150-200$ & 12 & 229 \\
\hline Hortense H.S. & 21 & $\begin{array}{r}7 / 75 \\
10 / 75 \\
1 / 76 \\
4 / 76\end{array}$ & $\begin{array}{l}1189 \\
1169 \\
1209 \\
129 q\end{array}$ & $\begin{array}{l}164 \\
156 \\
164 \\
186\end{array}$ & $\begin{array}{ll}57 & \mathrm{q} \\
54 & \mathrm{q} \\
56 & \mathrm{q} \\
61 & \mathrm{q}\end{array}$ & $\begin{array}{l}146 \\
144 \\
141 \\
145\end{array}$ & $\begin{array}{l}94 \\
93 \\
97 \\
93\end{array}$ & $150-200$ & $\begin{array}{l}- \\
18 \\
18 \\
17\end{array}$ & $\begin{array}{l}340 \\
336 \\
351 \\
341\end{array}$ \\
\hline $\begin{array}{l}\text { Hortense Hot Water } \\
\text { Well }\end{array}$ & 21 & $7 / 75$ & $118 \mathrm{q}$ & 164 & $56 q$ & 144 & 80 & $150-200$ & -- & 318 \\
\hline $\begin{array}{l}\text { Woolmington Hot } \\
\text { Water Well }\end{array}$ & 21 & $8 / 75$ & -- & $-\cdots$ & -- & 156 & 47 & $150-200$ & -- & 143 \\
\hline Unight Hot Well(E.) & 21 & $8 / 75$ & $103 q$ & 152 & $62 q$ & 148 & 62 & $150--200$ & - & 234 \\
\hline Tght Hot Well(W.) & 21 & $7 / 75$ & $116 q$ & 172 & $64 q$ & 145 & 77 & $150-200$ & -- & 313 \\
\hline
\end{tabular}


TABLE 3 (Cont.)

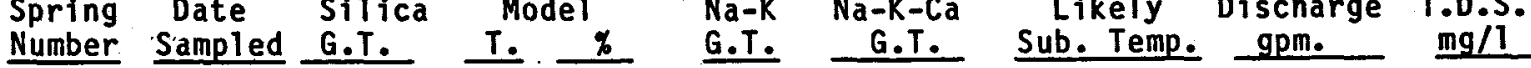

Chalk Creek Area Cont.

Young Life Hot Well

Clark Artesian Well $30 \quad 9 / 75,40 \mathrm{q}$

$188 \quad 71$ q 135

135

$68 \quad 150-200$

259

Colonel Chinn Hot

Water Well

$14 \quad 4 / 76$

$41 \mathrm{C}$

$6165 q$

$280-159$

25-50

1,210

Conundrum H.S.

$15 \quad 9 / 75$

$40 \mathrm{cr}$

$43 \quad 1 \mathrm{c} \quad 183 \quad 170$

Cottonwood H.S. Area:

Cottonwood H.S. 20

Jumpsteady H.S.

20

$6 / 75$

$110 \mathrm{q}$

$\begin{array}{llll}174 \quad 70 & 9 & 132\end{array}$

84

105-182

$10 E$

370

$\begin{array}{rr}10 / 75 & 108 \\ 1 / 76 & 109 \\ 19\end{array}$

$\begin{array}{llll}180 & 74 & q & 133\end{array}$

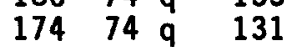

$4 / 76$

-.

$\begin{array}{llll}182 & 74 & 9 & 131 \\ -- & -- & \end{array}$

79

85

105-182

90

Merrifield Hot

$20 \quad 6 / 75 \quad 97 \quad 9$

$\begin{array}{llll}174 & 77 & q & 141\end{array}$

83

50
50

364

368

Water Well

Craig Warm Water

Well

$2 \quad 1 / 76$

$58 q$

$\begin{array}{llll}70 & 50 & q & 100\end{array}$

$41 \quad 68$

105-182

302

Dexter W.S.

$36 \quad 4 / 76 \quad--$

$3520 \mathrm{C}$

104

40-70

896

Don K. Ranch

Artesian We11

$29 \quad 9 / 75$

$42 \mathrm{cr}$

1936 a

$278--\overline{91}$

$20-50 \cdots 50 E$

Dotsero W.S.

$10 \quad 9 / 75$

$1 / 76$

$\overline{16} \mathrm{c}$

278

91

219190

$-113$

$\begin{array}{lllll}-\overline{27} & \overline{36} & \mathrm{c} & 104 & 113 \\ 2 & 26 & c & 104 & 144\end{array}$

$16 \mathrm{c}$

29. 26 c 104

112

2926 c 10

$102--109-$

109

$\begin{array}{rrrrrr}69 & 40 & c & 329 & -50 \\ 65 & 39 & c & 328 & 47\end{array}$

$6943 \mathrm{C}$

342

52

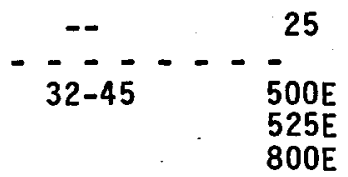

1,700

S. Dotsero W.S. $\quad 10 \quad 12 / 75 \quad 16$ c

Dunton H.S.

$\begin{array}{ll}9 / 75 & 54 \\ 1 / 76 & 51 \\ 4 / 76 & 53\end{array}$

Dutch Crowley

Artesian Well

$39 \quad 8 / 76 \quad 63 c$

$65 \quad 7$ c 271

16

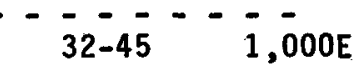

10,400

10,400
9,940

EIdorado Springs

Spring "A"
Spring " $B$ "

$8 \quad 9 / 75$

$23 \mathrm{c}$

$27 \quad 8 . c \quad 314$

43

$\overline{50-7 \overline{0}}$

$-26$

9,040

\begin{tabular}{|c|}
\hline $\begin{array}{l}9 / 75 \\
2 / 76\end{array}$ \\
\hline
\end{tabular}

$21 \mathrm{C} \quad 26 \quad 10 \mathrm{c} \quad 320$

$\begin{array}{llllll}21 & c & 26 & 19 & c & 254\end{array}$

$4 / 76$

$21 \mathrm{C}$

$261 \mathrm{c} 311$

$47 \mathrm{cr}$

$5938 \mathrm{cr} 2 \overrightarrow{2} \overline{1}$

45
57

46

$-$

70-80

1,260

Eoff Artesian Well $\quad 40 \quad 8 / 76$

Florence Artesian

Well (Penrose)

28. $9 / 75 \quad 34 c$

$4140 \mathrm{C}$

$212 \quad 178$

34-50

$26-40$

101

Freemont Natatorium

H.S.

27

$27 \quad 9 / 75$

$23 \mathrm{C}$

$21 \mathrm{c}$

$32 \quad 23$ c 172

$32 \quad 23$ c 174

$32 \quad 23$ c 171

72
73

35-50

26-40

25
25

1,340
1,300

Geyser W.S.

$52 \quad 9 / 75 \quad 58$ c

11380

71

160

$60-120-25-200 E$

20
20
18
-
$-25-200 E$

1,370

1,330

1,629 
TABLE 3 (Cont.)

\begin{tabular}{|c|c|c|c|c|c|c|c|c|c|c|c|}
\hline Hot Spring & $\begin{array}{l}\text { ing } \\
\text { ber }\end{array}$ & $\begin{array}{c}\text { Date } \\
\text { Sampled } \\
\end{array}$ & $\begin{array}{l}\text { Silica } \\
\text { G.T. }\end{array}$ & $\begin{array}{l}\text { Mixi } \\
\text { Mod } \\
T .\end{array}$ & $\%$ & & $\begin{array}{l}\mathrm{Na}-\mathrm{K} \\
\text { G.T. }\end{array}$ & $\begin{array}{c}\mathrm{Na}-\mathrm{K}-\mathrm{Ca} \\
\mathrm{G} . \mathrm{T} . \\
\end{array}$ & $\begin{array}{c}\text { Most } \\
\text { Likely } \\
\text { Sub. Temp. } \\
\end{array}$ & $\begin{array}{c}\text { Discharge } \\
\text { gpm. }\end{array}$ & $\begin{array}{r}\text { T.D.S. } \\
\mathrm{mg} / 1 \\
\end{array}$ \\
\hline$\frac{\text { Glenwood Springs Are }}{\text { Big Spring }}$ & a: & $7 / 75$ & $51 \mathrm{c}$ & 59 & 18 & c & 133 & 148 & -- & 2,263 & 20,200 \\
\hline Drinking Spring & 11 & $\begin{array}{r}7 / 75 \\
10 / 75 \\
1 / 76 \\
4 / 76\end{array}$ & $\begin{array}{ll}51 & c \\
47 & c \\
48 & c \\
48 & c\end{array}$ & $\begin{array}{l}59 \\
49 \\
51 \\
51\end{array}$ & $\begin{array}{r}18 \\
3 \\
0 \\
0\end{array}$ & & $\begin{array}{l}133 \\
131 \\
168 \\
135\end{array}$ & $\begin{array}{l}147 \\
145 \\
186 \\
149\end{array}$ & -- & $\begin{array}{l}-- \\
16 \overline{1} \\
140\end{array}$ & $\begin{array}{l}20,300 \\
20,200 \\
20,500 \\
18,800\end{array}$ \\
\hline $\begin{array}{l}\text { Vapor Caves, } \operatorname{Men}^{\circ} \mathrm{s} \\
\text { H.S. }\end{array}$ & 11 & $9 / 75$ & $45 \mathrm{c}$ & 49 & 3 & c & 129 & 143 & -- & $5 E$ & 18,000 \\
\hline Graves Spring & 11 & $9 / 75$ & $51 \mathrm{c}$ & 77 & 46 & c & 133 & 144 & -- & 5 & 21,500 \\
\hline Spring "A" & 11 & $7 / 75$ & $48 \mathrm{c}$ & 73 & 46 & c & 134 & 149 & $\cdots$ & $2-3 E$ & 17,600 \\
\hline Spring "B" & 11 & $\begin{array}{r}7 / 75 \\
10 / 75 \\
1 / 76 \\
4 / 76\end{array}$ & $\begin{array}{ll}48 & c \\
44 & c \\
45 & c \\
45 & c\end{array}$ & $\begin{array}{l}51 \\
47 \\
49 \\
49\end{array}$ & $\begin{array}{l}0 \\
9 \\
6 \\
6\end{array}$ & $\begin{array}{l}c \\
c \\
c \\
c\end{array}$ & $\begin{array}{l}135 \\
131 \\
133 \\
135\end{array}$ & $\begin{array}{l}149 \\
145 \\
165 \\
151\end{array}$ & - & $\begin{array}{r}75 \\
75 \\
100 \\
110\end{array}$ & $\begin{array}{l}18,300 \\
18,400 \\
17,700 \\
17,800\end{array}$ \\
\hline Spring "D" & 11 & $7 / 75$ & $48 \mathrm{c}$ & 51 & 2 & c & 133 & 147 & -- & 74 & 18,000 \\
\hline Railroad Spring & 11 & $\begin{array}{l}1 / 76 \\
4 / 76\end{array}$ & $\begin{array}{l}47 \mathrm{c} \\
47 \mathrm{c}\end{array}$ & $\begin{array}{l}49 \\
49 .\end{array}$ & $\begin{array}{l}6 \\
6\end{array}$ & $\begin{array}{l}\text { c } \\
\text { c }\end{array}$ & $\begin{array}{l}143 \\
138\end{array}$ & $\begin{array}{l}158 \\
152\end{array}$ & -- & $\begin{array}{r}75 \\
75\end{array}$ & $\begin{array}{l}18,400 \\
18,200\end{array}$ \\
\hline$\frac{\text { Hartsel Hot Springs }}{\text { Spring "A" }}$ & 19 & $6 / 75$ & $63 c$ & 85 & 44 & c & 162 & 152 & & -- & 2,280 \\
\hline Spring "B" & 19 & $\begin{array}{r}6 / 75 \\
10 / 75 \\
1 / 76 \\
4 / 76\end{array}$ & $\begin{array}{ll}59 & c \\
55 & c \\
56 & c \\
58 & c\end{array}$ & $\begin{array}{l}73 \\
79 \\
83 \\
87\end{array}$ & $\begin{array}{l}33 \\
46 \\
51 \\
53\end{array}$ & $\begin{array}{l}\text { c } \\
\text { c } \\
c \\
c\end{array}$ & $\begin{array}{l}163 \\
163 \\
161 \\
163\end{array}$ & $\begin{array}{l}152 \\
153 \\
152 \\
153\end{array}$ & & $\begin{array}{l}-- \\
40 \\
48 \\
50\end{array}$ & $\begin{array}{l}2,140 \\
2,260 \\
2,310 \\
2,330\end{array}$ \\
\hline $\begin{array}{l}\text { Haystack Butte } \\
\text { Warm Water Well }\end{array}$ & 7 & $9 / 75$ & $47 c$ & 57 & 53 & c & 52 & 62 & 50 & $4 E$ & 1,200 \\
\hline$\frac{\text { Hot Sulphur Springs }}{\text { Spring "A" }}$ & 6 & $\begin{array}{r}7 / 75 \\
10 / 75 \\
1 / 76 \\
4 / 76\end{array}$ & $\begin{array}{ll}86 & q \\
81 & q \\
81 & 9 \\
84 & 9\end{array}$ & $\begin{array}{r}109 \\
97 \\
97 \\
103\end{array}$ & $\begin{array}{l}63 \\
59 \\
59 \\
64\end{array}$ & & $\begin{array}{l}169 \\
166 \\
165 \\
169\end{array}$ & $\begin{array}{l}171 \\
166 \\
165 \\
168\end{array}$ & $75-150$ & $\begin{array}{l}-\overline{1} \\
12 \\
12 \\
13\end{array}$ & $\begin{array}{l}1,200 \\
1,210 \\
1,220 \\
1,160\end{array}$ \\
\hline Spring "B" & 6 & $7 / 75$ & $86 q$ & 113 & 67 & $q$ & 169 & 169 & $75-150$ & 1 & 1,200 \\
\hline Spring "C". & 6 & $\begin{array}{r}7 / 75 \\
10 / 75\end{array}$ & $\begin{array}{ll}86 & q \\
81 & q\end{array}$ & $\begin{array}{r}115 \\
99\end{array}$ & $\begin{array}{l}69 \\
64\end{array}$ & $\begin{array}{l}q r \\
q\end{array}$ & $\begin{array}{l}170 \\
165\end{array}$ & $\begin{array}{l}170 \\
164\end{array}$ & $75-150$ & $\begin{array}{r}3 \\
15\end{array}$ & $\begin{array}{l}1,210 \\
1,190\end{array}$ \\
\hline Spring "D" & 6 & $10 / 75$ & $80 q$ & 97 & 63 & $q$ & 167 & 166 & $75-150$ & 23 & 1,190 \\
\hline$\frac{\text { Idaho Hot Springs }}{\text { Spring "A" }}$ & 9 & $\begin{array}{r}7 / 75 \\
10 / 75 \\
2 / 76 \\
4 / 76\end{array}$ & $\begin{array}{l}66 \mathrm{cr} \\
59 \mathrm{cr} \\
71 \mathrm{cr} \\
78 \mathrm{cr}\end{array}$ & $\begin{array}{r}109 \\
95 \\
141 \\
171\end{array}$ & $\begin{array}{l}64 \\
63 \\
76 \\
81\end{array}$ & $\begin{array}{l}c r \\
c r \\
c r \\
c r\end{array}$ & $\begin{array}{l}231 \\
231 \\
225 \\
228\end{array}$ & $\begin{array}{l}210 \\
210 \\
204 \\
207\end{array}$ & -- & $\begin{array}{l}21 \\
-- \\
-- \\
--\end{array}$ & $\begin{array}{l}2,020 \\
2,110 \\
1,950 \\
1,940\end{array}$ \\
\hline Spring "B" & 9 & $7 / 75$ & $66 \mathrm{cr}$ & -- & - & & 230 & 210 & $\therefore$ & -- & 2,070 \\
\hline Spring "C" & 9 & $7 / 75$ & $47 \mathrm{cr}$ & -- & -- & & 235 & 206 & -- & 1 & 1,070 \\
\hline ' odge Well & 9 & $10 / 75$ & $59 \mathrm{cr}$ & 81 & 48 & cr & 231 & 210 & -- & $-\quad 30$ & 2,070 \\
\hline
\end{tabular}


TABLE 3 (Cont.)

\begin{tabular}{|c|c|c|c|c|c|c|c|c|c|c|c|c|}
\hline Hot Spring & $\begin{array}{l}\text { pring } \\
\text { lumber }\end{array}$ & $\begin{array}{c}\text { Date } \\
\text { Sampled }\end{array}$ & $\begin{array}{l}\text { Sil } \\
\text { G.T }\end{array}$ & & $\begin{array}{l}\text { Mixi } \\
\text { Mod } \\
\text { T. }\end{array}$ & $\begin{array}{l}\mathrm{ng} \\
\mathrm{el} \\
\mathrm{H}\end{array}$ & & $\begin{array}{l}\mathrm{Na-K} \\
\text { G.T. }\end{array}$ & $\begin{array}{c}\mathrm{Na}-\mathrm{K}-\mathrm{Ca} \\
\text { G.T. } \\
\end{array}$ & $\begin{array}{c}\text { Most } \\
\text { Likely } \\
\text { Sub. Temp. }\end{array}$ & $\begin{array}{c}\text { Discharge } \\
\text { gpm. } \\
\end{array}$ & $\begin{array}{l}\text { T.D.S } \\
\mathrm{mg} / \mathrm{I}\end{array}$ \\
\hline Juniper H.S. & 1 & $\begin{array}{r}7 / 75 \\
10 / 75 \\
1 / 76 \\
4 / 76\end{array}$ & $\begin{array}{l}53 \\
47 \\
50 \\
51\end{array}$ & & $\begin{array}{l}81 \\
73 \\
73 \\
81\end{array}$ & $\begin{array}{l}59 \\
61 \\
55 \\
61\end{array}$ & $\begin{array}{l}c \\
c \\
c \\
c\end{array}$ & $\begin{array}{l}75 \\
67 \\
70 \\
69\end{array}$ & $\begin{array}{l}80 \\
76 \\
78 \\
78\end{array}$ & $50-75$ & $\begin{array}{l}13 \\
14 \\
13 \\
18\end{array}$ & $\begin{array}{l}1,150 \\
1,160 \\
1,160 \\
1,150\end{array}$ \\
\hline Lemon H.S. & 50 & $\begin{array}{l}9 / 75 \\
1 / 76 \\
4 / 76\end{array}$ & $\begin{array}{l}15 \\
17 \\
14\end{array}$ & & $\begin{array}{l}29 \\
31 \\
29\end{array}$ & $\begin{array}{l}17 \\
15 \\
25\end{array}$ & $\begin{array}{l}\mathbf{a} \\
\mathbf{a} \\
\mathbf{a}\end{array}$ & $\begin{array}{l}210 \\
203 \\
207\end{array}$ & $\begin{array}{l}198 \\
192 \\
195\end{array}$ & - & $\begin{array}{r}8 \\
10 \\
10\end{array}$ & $\begin{array}{l}2,760 \\
2,810 \\
2,740\end{array}$ \\
\hline McIntyre W.S. & 37 & $4 / 76$ & -- & & 15 & 33 & 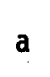 & $333^{-}$ & $-\overline{50}$ & $20-50$ & $5 \mathrm{E}$ & --- \\
\hline$\frac{\text { Mineral Hot Springs }}{\text { Spring "A" }}$ & $\underline{s} \quad 31$ & $\begin{array}{r}6 / 75 \\
10 / 75 \\
1 / 76 \\
4 / 76\end{array}$ & $\begin{array}{l}70 \\
67 \\
69 \\
69\end{array}$ & & $\begin{array}{l}87 \\
79 \\
83 \\
83\end{array}$ & $\begin{array}{l}38 \\
30 \\
34 \\
34\end{array}$ & $\begin{array}{l}c \\
c \\
c \\
c\end{array}$ & $\begin{array}{l}206 \\
202 \\
199 \\
202\end{array}$ & $\begin{array}{l}90 \\
90 \\
89 \\
90\end{array}$ & $70-90$ & $\begin{array}{r}100 \\
167 \\
70 \\
95\end{array}$ & $\begin{array}{l}643 \\
663 \\
658 \\
639\end{array}$ \\
\hline Spring "C" & 31 & $6 / 75$ & 72 & & 93 & 43 & c & 197 & 91 & $70-90$ & -- & 723 \\
\hline Spring "D" & 31 & $\begin{array}{r}6 / 75 \\
10 / 75 \\
1 / 76 \\
4 / 76\end{array}$ & $\begin{array}{l}70 \\
67 \\
68 \\
69\end{array}$ & & $\begin{array}{l}89 \\
79 \\
81 \\
83\end{array}$ & $\begin{array}{l}41 \\
30 \\
32 \\
34\end{array}$ & $\begin{array}{l}c \\
c \\
c \\
c\end{array}$ & $\begin{array}{l}202 \\
198 \\
195 \\
202\end{array}$ & $\begin{array}{l}92 \\
91 \\
87 \\
90\end{array}$ & $70-90$ & $\begin{array}{l}-- \\
-- \\
--\end{array}$ & $\begin{array}{l}665 \\
690 \\
657 \\
648\end{array}$ \\
\hline Orvis H.S. & 48 & $\begin{array}{l}9 / 75 \\
1 / 76 \\
4 / 76\end{array}$ & $\begin{array}{l}73 \\
82 \\
75\end{array}$ & & $\begin{array}{r}99 \\
127 \\
107\end{array}$ & $\begin{array}{l}54 \\
66 \\
54\end{array}$ & $\begin{array}{l}c \\
c \\
c\end{array}$ & $\begin{array}{l}179 \\
183 \\
187\end{array}$ & $\begin{array}{l}93 \\
97 \\
93\end{array}$ & -- & $\begin{array}{l}-1 \\
-1 \\
-1\end{array}$ & $\begin{array}{l}2,270 \\
2,490 \\
2,270\end{array}$ \\
\hline 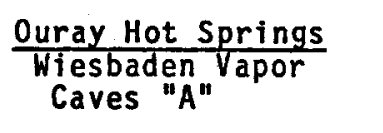 & 49 & $9 / 75$ & 61 & & 51 & 4 & c & 196 & 32 & $70-90$ & -- & 1,580 \\
\hline $\begin{array}{c}\text { Wiesbaden Vapor } \\
\text { Caves "B" }\end{array}$ & 49 & $9 / 75$ & 47 & c & 111 & 75 & c & 198 & 32 & $70-90$ & $2 \mathrm{E}$ & 695 \\
\hline $\begin{array}{l}\text { Wiesbaden Vapor } \\
\text { Caves "C" }\end{array}$ & 49 & $\begin{array}{l}9 / 75 \\
1 / 76 \\
4 / 76\end{array}$ & $\begin{array}{l}60 \\
60 \\
60\end{array}$ & & $\begin{array}{r}99 \\
161 \\
93\end{array}$ & $\begin{array}{l}56 \\
83 \\
51\end{array}$ & $\begin{array}{l}c \\
c \\
c\end{array}$ & $\begin{array}{l}299 \\
190 \\
192\end{array}$ & $\begin{array}{l}28 \\
41 \\
43\end{array}$ & $70--90$ & $\begin{array}{r}1 \mathrm{E} \\
30 \mathrm{E} \\
5 \mathrm{E}\end{array}$ & $\begin{array}{l}1,380 \\
1,430 \\
1,390\end{array}$ \\
\hline Pool H.S. & 49 & $\begin{array}{l}9 / 75 \\
1 / 76 \\
4 / 76\end{array}$ & $\begin{array}{l}69 \\
71 \\
71\end{array}$ & & $\begin{array}{l}77 \\
79 \\
79\end{array}$ & $\begin{array}{l}16 \\
15 \\
15\end{array}$ & $\begin{array}{l}c \\
c \\
c\end{array}$ & $\begin{array}{l}191 \\
184 \\
192\end{array}$ & $\begin{array}{l}39 \\
39 \\
39\end{array}$ & $70-90$ & $\begin{array}{r}125 \\
60 \\
200\end{array}$ & $\begin{array}{l}1,650 \\
1,660 \\
1,640\end{array}$ \\
\hline Uncompahgre H.S. & 49 & $4 / 76$ & 66 & c & 109 & 58 & c & 192 & 40 & $70-90$ & 5 & 1,570 \\
\hline$\frac{\text { Pagosa Spgs, }}{\text { Big Spg }}$ & 41 & $\begin{array}{r}8 / 75 \\
10 / 75 \\
1 / 76 \\
4 / 76\end{array}$ & $\begin{array}{l}76 \\
-- \\
80 \\
81\end{array}$ & $\begin{array}{l}c \\
c \\
c\end{array}$ & $\begin{array}{l}113 \\
-- \\
133 \\
139\end{array}$ & $\begin{array}{r}54 \\
- \\
64 \\
66\end{array}$ & $\begin{array}{l}c \\
c \\
c\end{array}$ & $\begin{array}{l}209 \\
209 \\
207 \\
210\end{array}$ & $\begin{array}{l}194 \\
194 \\
191 \\
193\end{array}$ & $80-150$ & $\begin{array}{l}265 \\
226 \\
241 \\
260\end{array}$ & $\begin{array}{c}3.200 \\
3, \overline{310} \\
3,040\end{array}$ \\
\hline $\begin{array}{l}\text { Courthouse hot } \\
\text { water well }\end{array}$ & 41 & $8 / 75$ & 74 & c & 113 & 56 & c & 210 & 193 & $75-125$ & 30 & 3,300 \\
\hline Spa Hot Water Well & 41 & $8 / 75$ & 73 & $c$ & 117 & 60 & c & 211 & 195 & $75-125$ & -- & 3,320 \\
\hline Paradise Hot Spring & 53 & $\begin{array}{l}9 / 75 \\
1 / 76 \\
4 / 76\end{array}$ & $\begin{array}{l}39 \\
56 \\
39\end{array}$ & & $\begin{array}{l}45 \\
53 \\
43\end{array}$ & $\begin{array}{l}4 \\
7 \\
1\end{array}$ & $\begin{array}{l}a \\
a \\
a\end{array}$ & $\begin{array}{l}247 \\
247 \\
245 \\
-\end{array}$ & $\begin{array}{r}252 \\
248 \\
250 \\
-\quad--\end{array}$ & -- & $\begin{array}{r}26 \\
34 \\
30 \\
-\quad-\quad-\end{array}$ & $\begin{array}{l}6,070 \\
6,530 \\
6,180\end{array}$ \\
\hline
\end{tabular}


TABLE 3 (Cont.)

\begin{tabular}{|c|c|c|c|c|c|c|c|c|c|c|}
\hline Hot Spring & $\begin{array}{l}\text { pring } \\
\text { umber }\end{array}$ & $\begin{array}{l}\text { Date } \\
\text { Sampled } \\
\end{array}$ & $\begin{array}{l}\text { Siltca } \\
\text { G.T. }\end{array}$ & $\begin{array}{l}\operatorname{Mixi} \\
\operatorname{Mod} \\
T\end{array}$ & $\begin{array}{l}\text { ng } \\
\text { lei } \\
\end{array}$ & $\begin{array}{l}\mathrm{Na}-K \\
\text { G.T. }\end{array}$ & $\begin{array}{c}\mathrm{Na}-\mathrm{K}-\mathrm{Ca} \\
\text { G.T. } \\
\end{array}$ & $\begin{array}{c}\text { Most } \\
\text { Likely } \\
\text { Sub. Temp. }\end{array}$ & $\begin{array}{l}\text { Discharge } \\
\text { gpm. }\end{array}$ & $\begin{array}{l}\text { T.D.S. } \\
\text { mg/i }\end{array}$ \\
\hline Penny Hot Springs & 13 & $\begin{array}{l}9 / 75 \\
1 / 76 \\
4 / 76\end{array}$ & $\begin{array}{r}15 a \\
39 a \\
39 a\end{array}$ & $\begin{array}{l}35 \\
35 \\
45\end{array}$ & $\begin{array}{r}25 a \\
48 a \\
2 a\end{array}$ & $\begin{array}{l}199 \\
197 \\
202\end{array}$ & $\begin{array}{l}93 \\
89 \\
92\end{array}$ & $60-90$ & $\begin{array}{l}10 \\
10 \\
10\end{array}$ & $\begin{array}{l}2,820 \\
2,820 \\
2,750\end{array}$ \\
\hline Granges Spring & 13 & $1 / 7.6$ & $7 a$ & 41 & $50 a$ & 198 & 90 & $60-90$ & 12 & 2,960 \\
\hline$\frac{\text { Pinkerton H.S. Area: }}{\text { Spring }}$ & 55 & $\begin{array}{l}9 / 75 \\
1 / 76 \\
4 / 76\end{array}$ & $\begin{array}{l}789 \\
789 \\
789\end{array}$ & $\begin{array}{l}127 \\
127 \\
133\end{array}$ & $\begin{array}{ll}81 & q \\
81 & 9 \\
82 & 9\end{array}$ & $\begin{array}{l}231 \\
231 \\
234\end{array}$ & $\begin{array}{l}205 \\
202 \\
206\end{array}$ & $75-125$ & $\begin{array}{l}54 \\
54 \\
54\end{array}$ & $\begin{array}{l}3,990 \\
3,880 \\
3,770\end{array}$ \\
\hline Spring " $B$ " & 55 & $9 / 75$ & $-\infty$ & -- & -- & 234 & 206 & $75-125$ & 20 & --- \\
\hline Mound Spring & 55 & $\begin{array}{l}9 / 75 \\
1 / 76 \\
4 / 76\end{array}$ & $\begin{array}{r}799 \\
789 \\
789\end{array}$ & $\begin{array}{l}139 \\
137 \\
137\end{array}$ & $\begin{array}{l}849 \\
859 \\
859\end{array}$ & $\begin{array}{l}234 \\
235 \\
235\end{array}$ & $\begin{array}{l}206 \\
206 \\
207\end{array}$ & $75-125$ & $\begin{array}{r}8 \mathrm{E} \\
5 \mathrm{E} \\
5 \mathrm{E}\end{array}$ & $\begin{array}{l}3,940 \\
3,880 \\
3,840\end{array}$ \\
\hline$\frac{\text { Poncha Hot Springs }}{\text { Spring "A" }}$ & 23 & $\begin{array}{r}6 / 75 \\
10 / 75 \\
1 / 76 \\
4 / 76\end{array}$ & $\begin{array}{l}126 \mathrm{q} \\
119 \mathrm{q} \\
137 \mathrm{q} \\
137 \mathrm{q}\end{array}$ & $\begin{array}{l}173 \\
157 \\
201 \\
201\end{array}$ & $\begin{array}{l}63 q \\
609 \\
69 \\
69\end{array}$ & $\begin{array}{l}155 \\
154 \\
154 \\
159\end{array}$ & $\begin{array}{r}99 \\
140 \\
141 \\
145\end{array}$ & $115-145$ & - & $\begin{array}{l}667 \\
678 \\
697 \\
654\end{array}$ \\
\hline Spring "B" & 23 & $6 / 75$ & $127 q$ & 183 & $68 \mathrm{q}$ & 154 & 139 & $115-145$ & $30 E$ & 655 \\
\hline Spring "C" & 23 & $\begin{array}{r}6 / 75 \\
10 / 75 \\
1 / 76 \\
4 / 76\end{array}$ & $\begin{array}{l}1269 \\
1199 \\
1309 \\
1369\end{array}$ & $\begin{array}{l}185 \\
169 \\
195 \\
209\end{array}$ & $\begin{array}{l}70 \mathrm{q} \\
68 \mathrm{q} \\
72 \mathrm{q} \\
73 \mathrm{q}\end{array}$ & $\begin{array}{l}157 \\
156 \\
154 \\
158\end{array}$ & $\begin{array}{r}96 \\
142 \\
141 \\
144\end{array}$ & $115-145$ & $\begin{array}{l}2 \\
3 \\
2 \\
4\end{array}$ & $\begin{array}{l}670 \\
660 \\
685 \\
655\end{array}$ \\
\hline Rainbow Hot Spring & 42 & $9 / 75$ & $41 \mathrm{cr}$ & 41 & $0 \mathrm{cr}$ & 68 & 22 & $40-50$ & 45 & 161 \\
\hline Ranger Warm Spring & 17 & $\begin{array}{r}7 / 75 \\
10 / 75 \\
1 / 76 \\
4 / 76\end{array}$ & $\begin{array}{ll}32 & c \\
28 & c \\
30 & c \\
30 & c\end{array}$ & $\begin{array}{l}67 \\
29 \\
45 \\
45\end{array}$ & $\begin{array}{rl}71 & c \\
1 & c \\
49 & c \\
49 c\end{array}$ & $\begin{array}{l}214 \\
216 \\
218 \\
217\end{array}$ & $\begin{array}{l}56 \\
66 \\
60 \\
60\end{array}$ & $30-60$ & $\begin{array}{l}132 \\
250 \mathrm{E} \\
225 \mathrm{E} \\
175 \mathrm{E}\end{array}$ & $\begin{array}{l}461 \\
465 \\
466 \\
474\end{array}$ \\
\hline Rhodes W.S. & 18 & $\begin{array}{r}6 / 75 \\
10 / 75\end{array}$ & $\begin{array}{l}10 \mathrm{c} \\
13 \mathrm{c}\end{array}$ & $\begin{array}{l}21 \\
23\end{array}$ & $\begin{array}{ll}65 & c \\
41 & c\end{array}$ & $\begin{array}{l}240 \\
222\end{array}$ & $\begin{array}{r}2 \\
10 \\
-\end{array}$ & $25-35$ & $\ddot{200}$ & $\begin{array}{l}186 \\
194\end{array}$ \\
\hline$\frac{\text { Rico }}{\text { Diamond Drill Hole }}$ & 54 & $1 / 76$ & $26 a$ & 39 & $18 a$ & 307 & 56 & - & 15 & 2,250 \\
\hline Big Geyser H.S. & 54 & $\begin{array}{l}9 / 75 \\
4 / 76\end{array}$ & $\begin{array}{l}22 a \\
35\end{array}$ & $\begin{array}{l}31 \\
37\end{array}$ & $\begin{aligned} 19 \mathrm{a} \\
1 \mathrm{a}\end{aligned}$ & $\begin{array}{l}297 \\
315\end{array}$ & $\begin{array}{l}57 \\
56\end{array}$ & 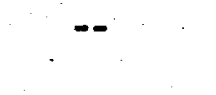 & $\begin{array}{r}8 \\
12\end{array}$ & $\begin{array}{l}2,750 \\
2,740\end{array}$ \\
\hline Geyser W.S. & 54 & $9 / 75$ & 22 a & 35 & $15 a$ & 301 & 59 & -- & 14 & 2,790 \\
\hline Little Spring & 54 & $\begin{array}{l}9 / 75 \\
1 / 76\end{array}$ & $\begin{array}{l}26 a \\
26\end{array}$ & $\begin{array}{l}35 \\
37\end{array}$ & $\begin{array}{l}15 \mathrm{a} \\
10 \mathrm{a}\end{array}$ & $\begin{array}{l}305 \\
185 \\
-\end{array}$ & $\begin{array}{l}58 \\
17 \\
--\end{array}$ & -- & $\begin{array}{r}13 \\
15\end{array}$ & $\begin{array}{l}2,790 \\
2,700\end{array}$ \\
\hline$\frac{\text { Routt Hot Springs }}{\text { Spring "A" }}$ & 3 & $\begin{array}{r}7 / 75 \\
10 / 75 \\
1 / 76 \\
4 / 76\end{array}$ & $\begin{array}{l}1369 \\
1259 \\
1299 \\
1319\end{array}$ & $\begin{array}{l}225 \\
199 \\
209 \\
213\end{array}$ & $\begin{array}{ll}75 & q \\
71 & q \\
73 & q \\
73 & q\end{array}$ & $\begin{array}{l}170 \\
165 \\
167 \\
169\end{array}$ & $\begin{array}{l}154 \\
154 \\
155 \\
157\end{array}$ & $125-175$ & $\begin{array}{l}33 \\
50 \\
25 \\
35\end{array}$ & $\begin{array}{l}552 \\
518 \\
521 \\
527\end{array}$ \\
\hline Spring "B" & 3 & $7 / 75$ & $136 q$ & 231 & $76 q$ & 170 & 159 & $125-175$ & $-{ }_{-}^{30}$ & 539 \\
\hline Sand Dunes Hot Well & 34 & $8 / 75$ & $26 a$ & 39 & $19 a$ & 205 & 187 & -- & - & 334 \\
\hline
\end{tabular}


TABLE 3 (cont.)

\begin{tabular}{|c|c|c|c|c|c|c|c|c|c|c|c|c|}
\hline Hot Spring & $\begin{array}{l}\text { pring } \\
\text { umber }\end{array}$ & $\begin{array}{l}\text { Date } \\
\text { Sampled }\end{array}$ & $\begin{array}{l}\text { Sili } \\
\text { G.T. }\end{array}$ & & $\begin{array}{l}\text { Mixi } \\
\text { Mod } \\
T .\end{array}$ & $\begin{array}{l}\mathrm{ng} \\
\mathrm{el} \\
\% \\
\end{array}$ & & $\begin{array}{l}\mathrm{Na}-\mathrm{K} \\
\text { G.T. }\end{array}$ & $\begin{array}{c}\mathrm{Na}-\mathrm{K}-\mathrm{Ca} \\
\mathrm{G} . \mathrm{T} . \\
\end{array}$ & $\begin{array}{r}\text { Most } \\
\text { Likely } \\
\text { Sub. Temp. }\end{array}$ & $\begin{array}{l}\text { Discharge } \\
\text { gpm. }\end{array}$ & $\begin{array}{l}\text { T.D.S. } \\
\text { mg/l }\end{array}$ \\
\hline Shaws W.S. & 33 & $\begin{array}{r}8 / 75 \\
10 / 75 \\
1 / 76 \\
4 / 76\end{array}$ & $\begin{array}{r}8 \\
2 \\
17 \\
4\end{array}$ & & $\begin{array}{l}26 \\
26 \\
28 \\
26\end{array}$ & $\begin{array}{l}32 \\
32 \\
19 \\
32\end{array}$ & $\begin{array}{l}a \\
a \\
a \\
a\end{array}$ & $\begin{array}{r}101 \\
98 \\
101 \\
100\end{array}$ & $\begin{array}{r}103 \\
104 \\
83 \\
102\end{array}$ & $30-60$ & $\begin{array}{r}34 \\
34 \\
52 \\
\quad 40\end{array}$ & $\begin{array}{l}406 \\
402 \\
424 \\
398\end{array}$ \\
\hline$\frac{\text { South Canyon H. S. }}{\text { Spring "A" }}$ & 12 & $\begin{array}{r}7 / 75 \\
10 / 75 \\
1 / 76 \\
4 / 76\end{array}$ & $\begin{array}{l}66 \\
60 \\
67 \\
63\end{array}$ & & $\begin{array}{l}123 \\
103 \\
127 \\
115\end{array}$ & $\begin{array}{l}67 \\
60 \\
68 \\
65\end{array}$ & & $\begin{array}{l}138 \\
137 \\
140 \\
140\end{array}$ & $\begin{array}{l}137 \\
135 \\
137 \\
137\end{array}$ & $100-130$ & $\begin{array}{r}12 \\
7 \\
9 \\
17\end{array}$ & $\begin{array}{l}794 \\
800 \\
783 \\
772\end{array}$ \\
\hline Spring "B" & 12 & $7 / 75$ & 65 & c & 119 & 66 & c & 139 & 137 & $100-130$ & $1 E$ & 757 \\
\hline Splashland Hot Well & 135 & & 22 & a & 35 & 23 & a & $221^{-}$ & 197 & $40-100$ & - & 311 \\
\hline$\frac{\text { Steamboat Springs }}{\text { Heart Spring }}$ & 4 & $4 / 76$ & 101 & $\mathbf{q}$ & 179 & 81 & $q$ & 148 & 141 & $125-130$ & 140 & 903 \\
\hline Sulphur Cave & 4 & $4 / 76$ & 60 & $q$ & 79 & 79 & $q$ & 181 & 188 & $125-130$ & 10 & 4,530 \\
\hline Steamboat Spring & 4 & $4 / 76$ & 66 & $q$ & 93 & 76 & $q$ & 176 & 187 & $125-130$ & 20 & 6,170 \\
\hline Stinking Springs & 38 & $9 / 75$ & 39 & c & 59 & 61 & c & $339^{-}$ & $\begin{array}{l}-\overline{4} \\
--\end{array}$ & $40-60$ & $-{ }^{-} 24$ & 899 \\
\hline$\frac{\text { Swissvale Warm Spgs. }}{\text { Spring "A" }}$ & 25 & $6 / 76$ & 32 & cr & 35 & 22 & $\mathrm{cr}$ & 214 & 48 & $35-50$ & 125 & -- \\
\hline Spring "F" & 25 & $6 / 76$ & 31 & cr & 47 & 69 & $\mathrm{cr}$ & 2 & 44 & $35-50$ & 20 & -- \\
\hline Trimble H.S. & 56 & $9 / 75$ & - & & 34 & 47 & a & 197 & 97 & $45-70$ & $1 E$ & 3,340 \\
\hline Tripp H.S. & & $9 / 75$ & -- & & 30 & 39 & $\mathbf{a}$ & $\begin{array}{c}198 \\
-\end{array}$ & $\begin{array}{r}99 \\
--\end{array}$ & $45-70$ & $\therefore$ & 3,240 \\
\hline$\frac{\text { Valley View Hot Spgs }}{\text { Spring "A" }}$ & gs. 32 & $\begin{array}{r}6 / 75 \\
10 / 75 \\
1 / 76 \\
4 / 76\end{array}$ & $\begin{array}{l}34 \\
32 \\
32 \\
32\end{array}$ & & $\begin{array}{l}37 \\
35 \\
35 \\
35\end{array}$ & $\begin{array}{l}4 \\
9 \\
5 \\
9\end{array}$ & $\begin{array}{l}c \\
c \\
c \\
c\end{array}$ & $\begin{array}{l}356 \\
356 \\
352 \\
375\end{array}$ & $\begin{array}{l}12 \\
14 \\
15 \\
15\end{array}$ & $40-50$ & $\begin{array}{l}-- \\
60 E \\
-- \\
--\end{array}$ & $\begin{array}{l}252 \\
249 \\
243 \\
234\end{array}$ \\
\hline Spring "B" & 32 & $6 / 75$ & 30 & c & 31 & 12 & c & 338 & 11 & $40-50$ & -- & 234 \\
\hline Wagon Wheel Gap & 32 & $\begin{array}{r}10 / 75 \\
1 / 76 \\
4 / 76\end{array}$ & $\begin{array}{l}25 \\
28 \\
28\end{array}$ & & $\begin{array}{l}29 \\
31 \\
31\end{array}$ & $\begin{array}{l}33 \\
25 \\
29\end{array}$ & $\begin{array}{l}c \\
c \\
c\end{array}$ & $\begin{array}{c}360 \\
346 \\
389 \\
--\end{array}$ & $\begin{array}{l}11 \\
16 \\
10 \\
----\end{array}$ & $-\cdots$ & $\begin{array}{r}120 \mathrm{E} \\
75 \mathrm{E} \\
75 \mathrm{E} \\
---\end{array}$ & $\begin{array}{l}229 \\
247 \\
223\end{array}$ \\
\hline 4UR Spring & 43 & $\begin{array}{r}10 / 75 \\
1 / 76 \\
4 / 76\end{array}$ & $\begin{array}{l}75 \\
81 \\
77\end{array}$ & $\begin{array}{l}c r \\
c r \\
c r\end{array}$ & $\begin{array}{l}113 \\
137 \\
119\end{array}$ & $\begin{array}{l}56 \\
66 \\
59\end{array}$ & $\begin{array}{l}c r \\
c r \\
c r\end{array}$ & $\begin{array}{l}206 \\
204 \\
200\end{array}$ & $\begin{array}{l}194 \\
191 \\
188\end{array}$ & -- & $\begin{array}{l}30 E \\
30 E \\
28 E\end{array}$ & $\begin{array}{l}1,580 \\
1,550 \\
1,620\end{array}$ \\
\hline CF́ \& I Spring & 43 & $\begin{array}{r}8 / 75 \\
10 / 75 \\
1 / 76 \\
4 / 76\end{array}$ & $\begin{array}{l}71 \\
66 \\
80 \\
66\end{array}$ & $\begin{array}{l}c r \\
c r \\
c r \\
c r\end{array}$ & $\begin{array}{r}117 \\
99 \\
157 \\
99\end{array}$ & $\begin{array}{l}64 \\
56 \\
76 \\
57\end{array}$ & $\begin{array}{l}c r \\
c r \\
c r \\
c r\end{array}$ & $\begin{array}{c}205 \\
203 \\
203 \\
206 \\
--\end{array}$ & $\begin{array}{l}181 \\
184 \\
175 \\
181 \\
--\end{array}$ & $\therefore---$ & $\begin{array}{r}30 \\
50 \\
30 \\
-32 \\
---\end{array}$ & $\begin{array}{l}1,510 \\
1,520 \\
1,540 \\
1,470\end{array}$ \\
\hline$\frac{\text { Waunita Hot Springs }}{\text { Spring "C" }}$ & 46 & $\begin{array}{r}7 / 75 \\
10 / 75 \\
1 / 76 \\
4 / 76\end{array}$ & $\begin{array}{l}143 \\
143 \\
157 \\
148\end{array}$ & & $\begin{array}{l}213 \\
209 \\
247 \\
225\end{array}$ & $\begin{array}{l}66 \\
64 \\
71 \\
68\end{array}$ & & $\begin{array}{l}179 \\
176 \\
174 \\
178\end{array}$ & $\begin{array}{l}163 \\
166 \\
159 \\
167\end{array}$ & $175-225$ & $\begin{array}{l}-- \\
30 \\
55 \\
50\end{array}$ & $\begin{array}{l}557 \\
579 \\
613 \\
575\end{array}$ \\
\hline Spring "D" & 46 & $7 / 75$ & 153 & $\mathbf{q}$ & 291 & 83 & $\mathbf{q}$ & 175 & 165 & $175-225$ & - & \\
\hline
\end{tabular}


TABLE 3 (Cont.)

\begin{tabular}{|c|c|c|c|c|c|c|c|c|c|c|}
\hline Hot Spring & $\begin{array}{l}\text { Spring } \\
\text { Number }\end{array}$ & $\begin{array}{c}\text { Date } \\
\text { Sampled } \\
\end{array}$ & $\begin{array}{l}\text { Silica } \\
\text { G.T. }\end{array}$ & $\begin{array}{l}\text { Mixi } \\
\text { Mod } \\
T .\end{array}$ & $\begin{array}{l}19 \\
01 \\
\%\end{array}$ & $\begin{array}{l}\mathrm{Na}-\mathrm{K} \\
\text { G.T. }\end{array}$ & $\begin{array}{c}\mathrm{Na}-\mathrm{K}-\mathrm{Ca} \\
\mathrm{G} . \mathrm{T} . \\
\end{array}$ & $\begin{array}{c}\text { Most } \\
\text { Likely } \\
\text { Sub. Temp. }\end{array}$ & $\begin{array}{c}\text { Discharge } \\
\text { gpm. } \\
\end{array}$ & $\begin{array}{r}\text { T.D.S. } \\
\mathrm{mg} / 1 \\
\end{array}$ \\
\hline$\frac{\text { Lower Waunita H.S. }}{\text { Spring "B" }}$ & - & $\begin{array}{r}7 / 75 \\
10 / 75 \\
4 / 76\end{array}$ & $\begin{array}{l}1309 \\
123 \\
129 \\
129\end{array}$ & $\begin{array}{l}197 \\
181 \\
195\end{array}$ & $\begin{array}{l}67 \\
64 \\
q 7 \\
67 \\
q\end{array}$ & $\begin{array}{l}178 \\
176 \\
179\end{array}$ & $\begin{array}{l}165 \\
163 \\
165\end{array}$ & $110-160$ & $\begin{array}{l}-\overrightarrow{20 E} \\
25 E\end{array}$ & $\begin{array}{l}544 \\
549 \\
528\end{array}$ \\
\hline $\begin{array}{l}\text { Lower Waunita H.S. } \\
\text { Spring "D" }\end{array}$ & 46 & $7 / 75$ & $129 q$ & 209 & $73 \mathrm{q}$ & 179 & 166 & $110-160$ & - & 535 \\
\hline Wellsvilie W.S. & 24 & $\begin{array}{r}6 / 75 \\
10 / 75 \\
1 / 76 \\
4 / 76\end{array}$ & $\begin{array}{l}32 \mathrm{cr} \\
30 \mathrm{cr} \\
31 \mathrm{cr} \\
31 \mathrm{cr}\end{array}$ & $\begin{array}{l}33 \\
33 \\
33 \\
33\end{array}$ & $\begin{array}{r}2 \mathrm{cr} \\
7 \mathrm{cr} \\
15 \mathrm{cr} \\
15 \mathrm{cr}\end{array}$ & $\begin{array}{l}213 \\
214 \\
216 \\
213\end{array}$ & $\begin{array}{l}49 \\
49 \\
48 \\
50\end{array}$ & $35-50$ & $\begin{array}{l}-1 \\
160 \\
175 \\
200\end{array}$ & $\begin{array}{l}470 \\
484 \\
482 \\
482\end{array}$ \\
\hline
\end{tabular}




\section{TABLE 4}

\section{REPORT BUT UNCONFIRMED HOT SPRINGS OR WELLS}

The following sources of thermal water have been brought to the author's attention. These sources have not yet been field checked or located.

1. Burgener Spring, T. 49 N., R. 9 E., Sec. ?, N.M.P.M., Howard quadrangle, Chaffee County. Reported by Mrs. John Burgener, 1978. A small spring located on their property along Bear Creek.

2. Radium Warm Spring, T. 5 S., R. $90 \mathrm{~W}$. Sec. 34 da, Storm King Mountain quadrangle, Garfield County. Reported by Chenn and Ássociates. A small unused spring located on the south bank of the Colorado River. 


\section{TABLE 5}

WELLS IN THE SAN LUIS VALLEY haVING MEASURED TEMPERATURES ABOVE $20^{\circ}$

(Adapted from Emery, Snipes and Dumeyer, 1972)

Location

T. 37 N., R. 9 E, Sec. $15 . \mathrm{ddc}$

T. 37 N., R. 9 E, Sec. 28 ccb2

T. 37 N., R. 10 E. Sec. $5 \mathrm{dbb}$

T. 37 N., R. 10 E. Sec. 11 ccc

T. 37 N., R. $10 \mathrm{E}$, Sec. $32 \mathrm{cdc} 2$

T. 37 N. R. $11 \mathrm{E}$, Sec. $9 \mathrm{cbb}$

T. 37 N.: R. $11 \mathrm{E}$, Sec. 22 cccl

T. 38 N., R. 9 E, Sec. I ada

T. 38 N., R. $9 \mathrm{E}$, Sec. 22 cbc

T. 38 N., R. $10 \mathrm{E}$, Sec. 11 acc

T. $38 \mathrm{~N}$, , R. $10 \mathrm{E}$, Sec. 24 aaa

T. $38 \mathrm{~N} ., \mathrm{R} .10 \mathrm{E}, \mathrm{Sec} .36 \mathrm{ccc}$

T. 38 N., R. $11 \mathrm{E}$, Sec. $9 \mathrm{cdb}$

T. 39 N., R. 10 E, Sec. 3 ced

T. 39 N., R. $10 \mathrm{E}$, Sec. $6 \mathrm{bbb}$

T. 39 N., R. $10 \mathrm{E}$, Sec. 13 bbb

T. 39 N., R. 11 E, Sec. 5 cdd

T. 40 N., R. $9 \mathrm{E}$, Sec. 11 bcc3

T. 40 N., R. $10 \mathrm{E}$, Sec. $22 \mathrm{bbb}$

T. 40 N., R. $10 \mathrm{E}$, Sec. 34 abc

T. 35 N., R. 11 E, Sec. $5 \mathrm{cac}$

T. $36 \mathrm{~N}$., R. $11 \mathrm{E}$, Sec. $30 \mathrm{dba}$

T. 36 N., R. 11 E, Sec. 34 ccc

T. 31 N., R. 75 W, Sec. 23 dda

T. 41 N., R. 9. E, Sec. $25 \mathrm{ccc}$

T. 41 N., R. 10 E, Sec. 27 aa

T. 41 N., R. $11 \mathrm{E}$, Sec. 2 bc

T. 42 N., R. $11 \mathrm{E}$, Sec. $36 \mathrm{~cd}$

T. 43 N, , R. $8 \mathrm{E}$, Sec: 7 aaa

T. 43 N., R. 10 E, Sec. $10 \mathrm{cad}$

T. 43 N., R. 11 E, Sec. 32 cd

T. $45 \mathrm{~N} .$, R. $10 \mathrm{E}$, Sec. $7 \mathrm{bcb}$.

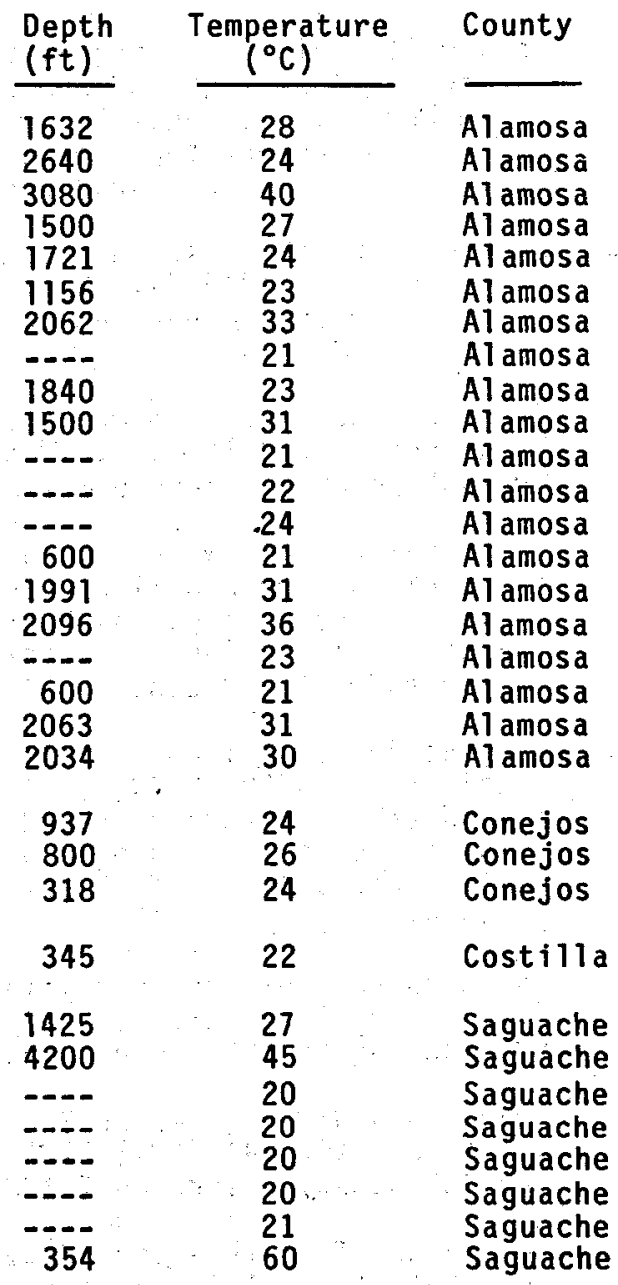




\section{TABLE 6}

\section{NEWLY LOCATED THERMAL WELLS IN THE CANON CITY AREA}

1. Valle Cuatro Millas Artesian Well, Latitude $38^{\prime} 28^{\circ} 29^{\prime \prime}$ N., Longitude $105^{\circ} 11^{\prime} 30^{\prime \prime}$ W, T. $18 \mathrm{~S}$., R. 70 W., Sec. 23 ba, 6th P.M., Fremont County, Canon City, 7 1/2 minute topographic quadrangle map.

This well, which is reported to be between 2200 and 2900 feet deep, is located just south of the golf clubhouse west of the dirt road along Four Mile Creek. The water, which has a temperature of $26^{\circ} \mathrm{C}$, is used for domestic purposes at the ranch house approximately one-half mile to the south and on the golf course grounds (Fig 25).

2. Four Mile Creek Artesian Thermal Well. Latitude: $38^{\circ} 31^{\prime} 13^{\prime \prime}$ N.; Longitude: $105^{\circ} 12^{\prime} 52^{\prime \prime W}$., T. 17 S., R. 70 W., Sec. 34 cc 6th P.M. Fremont County, Cooper Mountain $71 / 2$ minute topographic quadrangle map.

3. Brush Hollow Creek Thermal Artesian We11. Latitude: $38^{\prime} 25^{\circ} 26^{\prime \prime}$; Longitude: $105^{\circ} 3^{\prime} 15^{\prime \prime W}$; T. 19 S., R. 69 W., Sec. 1 daa 6 th P.M. Fremont County, Florence $71 / 2$ minute topographic quadrangle map.

This unused well, which has a temperature of $32^{\circ} \mathrm{C}$, is located along the banks of Brush Hollow Creek approximately 100 yards north of U.S. 50. The casing, which extends up above ground level for approximately $10 \mathrm{feet}$, is encased in mineral matter. The well has an estimated discharge of $100 \mathrm{gpm}$ (Fig. 26).

4. Higgins Artesian Thermal Well. Latitude: $38^{\circ} 25^{\prime} 07^{\prime \prime} \mathrm{N}$;

Long itude: $105^{\circ} 03^{\prime} 28^{\prime \prime W}$; T. 19 S., R. 69 W., Sec. 1 dcd.

The waters from this reported $1875 \mathrm{ft}$ deep well which have a temperature of $42^{\circ} \mathrm{C}$, are used to heat a house and in a swimming pool. According to Ms. Hazel Higgins, the well was drilled in 1924.

To reach the well go approximately $0.7 \mathrm{mi}$ west of the junction of U.S. 50 and Colo. 115 to a dirt road leading to the south. Take this road and go to the house approximately 0.4 miles (Fig. 26).

5. American Nauheim Artesian Thermal Wel1. Latitude $38^{\circ} 23^{\prime} 23^{\prime \prime} \mathrm{N}$;

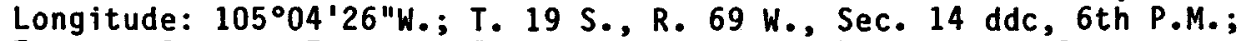
Fremont County, Florence $71 / 2$ minute topograhic quadrangle map.

The waters from this unused well have a temperature of $27^{\circ} \mathrm{C}$. The depth of the well is reported by Mr. George Goodwin to be approx. $1400 \mathrm{ft}$. The well is located on the west side of the old swimming pool approximately $1 / 4 \mathrm{mile}$ north of the intersection of Colo. 115 and Colo. 120 (Fig. 26).

At one time, according to Mr. Goodwin, the well had a discharge of $200 \mathrm{gpm}$, but is much less than that now. 


\section{REFERENCES}

Barrett, J.K., and Pearl, R.H., 1976, Hydrogeological data of thermal springs and weils in Colorado: Colorado Geol. Survey Inf. Ser. 6, 124 p. 1978, An appraisal of Colorado's geothermal resources: Colorado Geol. Survey Bull. 39, 224 p.

Barrett, J.K., Pearl, R.H., and Pennington, A.J., 1976, Map showing thermal springs, wells and heat-flow contours in Colorado: Colorado Geol. Survey Inf. Ser. 4, 1 pl., scale 1:1,000,000.

Bass, N.W., and Northrop, S.A., 1963, Geology of Glenwood Springs quadrangle and vicinity, northwestern Colorado: U.S. Geol. Survey Bull. 1142-J, 74 p.

Bastin, E.S., 1922, Silver enrichment in the San Juan Mountains, Colorado: U.S. Geol. Survey Bul1. 735, 129 p.

Boos, C.M., and Boos, M.F., 1957, Tectonics of eastern flank and foothills of Front Range, Colorado: Am. Assoc. Petroleum Geologists Bull., v. 41, no. 12, p. 2603-2676.

Brogden, R.E., and Giles, T.F., 1976, Availability and chemical quality of ground water in the Crystal River and Cattle Creek drainage basins near Glenwood Springs, west-central Colorado: U.S. Geol. Survey Water Resources Inv. 76-70, sheet (geologic map scale $1: 125,000$ ).

Brook, C.A., and others, 1979, Hydrothermal convection systems with reservoir temperatures equal to or above $90^{\circ} \mathrm{C}$, in As sessment of geothermal resources of the United States--1978, L.J.P. Muffler (ed): U.S. Geol. Survey Circ. 790, p. 18-85.

Bryant, Bruce, 1969, Geologic map of the Maroon Bell's quadrangle, Pitkin and Gunnison Counties, Colorado: U.S. Geol. Survey Quad. Map GQ-788.

1970, Geologic map of the Hayden Peak quadrangle, Pitkin and Gunnison Counties, Colorado: U.S. Geol. Survey Geol. Quad. Map GQ-863.

Burroughs, R.L., 1971, Geology of the San Luis Hills, south-central Colorado, in Guidebook of the San Luis Basin, Colorado: New Mexico Geol. Soc. 22nd Field Conference, p. 277-287.

Bush, A.L., and Bromfield, C.S., 1966, Geologic map of the Dolores Peak quadrangle, Dolores and San Miguel Counties, Colorado: U.S. Geol. Survey Geo1. Quad. Map GQ-536.

Bush, A.L.,. Bromfield, C.S., and Pierson, T.L., 1956, Preliminary geologic map of the Placerville quadrangle, Colorado: U.S. Geol. Survey Mineral Inv. Field Studies Map MF-96.

Chapin, C.E., 1971, The Rio Grande Rift, part I-Modifications and additions, in Guidebook of the San Luis Basin, Colorado: New Mexico Geol. Soc. 22nd Field Conference, p. 191-202.

Chronic, John, 1964, Geology of the southern Mosquito Range, Colorado: Mtn. Geologist, v. 1 , no. 3, p. 103-113.

Coe, Barbara, 1978, Geothermal energy development in Colorado: Processes, Promises, and Problems: Colorado Geol. Survey Inf. Ser. 9, 52 p:

Conley, C.D., 1958, Geology of the Chromo anticline, Archuleta County, Colorado and Rio Arriba County, New Mexico: Colorado School Mines Master Scj. Thesis T-879.

DeVoto, R.H., 1971, Geologic history of South Park and geology of the Antero Reservoir quadrangle, Colorado: Colorado School Mines Quart., v. 66 , no. 3, 90 p.

Dick, J.D., 1976, Geothermal reservoir temperatures in Chaffee County, Colorado: Northeast Louisiana Univ., Dept. of Geology, Master Sci. Thesis, $171 \mathrm{p}$.

Emery, P.A., 1971, Water resources of the San Luis Valley, Colorado; in Guidebook of the San Luis Basin, Colorado: New Mexico Geol. Soc. 22nd Field Conf., p. 129-132.

Emery, P.A., Boettcher, A.J., Snipes, R.J., and McIntyre, H.J., Jr., 1971, Hydrology of the San Luis Valiey, south-central Colorado: U.S. Geol. Survey Hydrol. Inv. Atl as HA-381.

Emery, P.A., Snipes, R.J., and Dumeyer, J.M., 1972, Hydrogeologic data for the San Luis Valley, Colorado: Colorado Water Conserv. Board Basic-data release No. 22, 146 p.

Emmons, W.H., and Larsen, E.S., 1913, The hot springs and mineral deposits of Wagon Wheel Gap, Colorado: Econ. Geology, v. 8, p. 235-246.

Fournier, R.0., 1973, Silica in themal waterslaboratory and field investigations, in Proceedings of International Symposium on Hydrogeochemistry. and Biogeochemistry, Japan, 1970, v. 1--Hydrogeochemistry, J.W. Clark: Washington, p. 122-139.

1977, Chemical geothermometers and mixing models for geothermal systems: Geothermics, v. 5 , p. 41-50. 
Fournier, R.0., and Rowe, J.J., 1966, Estimation of underground temperatures from the silica content of water from hot springs and wet-steam wells: Am. Jour. Sci., v. 264, p. 685-697.

Fournier, R.0., and Truesdell, A.H., 1972, Chemical indicators of subsurface temperature applied to hot spring waters of Yellowstone National Park, Wyoming, U.S.A.: Geothermics, Special Issue 2, p. 5429-535.

1973, An emprical $\mathrm{Na}-\mathrm{K}-\mathrm{Ca}$ geothermometer for natural waters: Geochim. et Cosmochim. Acta, v. 37, p. 1255-1275.

1974, Geochemical indicators of subsurface temperatures, part 2--Estimation of temperature and fraction of hot water mixed with cold water: U.S. Geol. Survey Jour. Research, v. 2 , no. 3 , p. 263-270.

Fournier, R.0., White, D.E., and Truesdell, A.H., 1974, Geochemical indicators of subsurface temperatures, part 1--Basic assumptions: U.S. Geol. Survey Jour. Research, v. 2 , no. 3 , p. 259-262.

Gaca, J.R., and Karig, D.E., 1966, Gravity survey in the San Luis Valley area, Colorado: U.S. Geol. Survey open-file rept., 16 p.

Galloway, M., 1979, Hydrogeologic and geothermal investigation of Pagosa Springs, Colorado: Colorado Geol. Survey Spec. Pub. 10, (in press).

George, R.D., and others, 1920 , Mineral waters of Colorado: Colorado Geol. Survey Bull. $11,474 \mathrm{p}$.

Godwin, L.H., and others, 1971, Classification of public lands valuable for geothermal steam and associated geothermal resources: U.S. Geol. Survey Circ. 647, $18 \mathrm{p}$.

Grose, L.T., 1974, Summary of geology of Colorado related to geothermal energy potential; in Proceedings of a symposium on geothermal energy and Colorado: Colorado Geol. Survey Bull. 35, p. 11-29.

Hail, W.J., Jr., 1965, Geology of northwestern North Park, Colorado: U.S. Geol. Survey Bull. 1188,133 p.

1972, Reconnaissance geologic map of the Hotchkiss area, Delta and Montrose Counties, Colorado: U.S. Geol. Survey Misc. Geol. Inv. Map I-698 (scale $1: 48,000$ ).

Harrison, J.E., and Wells, J.D., 1959, Geology and ore deposits of the Chicago Creek area,
Clear Creek County, Colorado: U.S. Geol. Survey Prof. Paper 319, 92 p.

Hedlund, D.C., and 0lson, J.C., 1975, Geologic map of the Powderhorn quadrangle, Gunnison and Saguache Counties, Colorado: U.S. Geol. Survey Geol. Quad. Map GQ-1178.

Hunter, Z.M., 1955, Geology of the foothills of the Front Range in northern Colorado: Rocky Mtn. Assoc. Geologists, 2 maps (scale 1: 48,000).

Izett, G.A., 1968, Geology of the Hot Sulphur Springs quadrangle, Grand County, Colorado: U.S. Geol. Survey Prof. Paper 586, 79 p.

Izett, G.A., and Barclay, C.S.V., 1964, Preliminary geologic map of the Hot Sulphur Springs SW quadrangle, Grand County, Colorado: U.S. Geo1. Survey Mineral Inv. Field Studies, Map-291.

Izett, G.A., and Hoover, D.L., 1963, Preliminary geologic map of the Hot Sulphur Springs SE quadrangle, Grand County, Colorado: U.S. Geol. Survey Mineral Inv. Field Studies Map MF-271.

Johnson, R.B., 1969, Geologic map of the Trinidad quadrangle, south-central Colorado: U.S. Geol. Survey Misc. Geol. Inv. Map I-558.

Kilgore, L.W., and C1 ark, P.E., 1961, Animas Valley cross section, in Berg, R.R., and Rold, J.W., eds., Symposium on Lower and Middle Paleozoic rocks of Colorado--12th Field Conf.: Rocky Mtn. Assoc. Geologists, p. 235.

Klein, J.M., 1976, Chemistry of silica in the ground water of the San Luis Valley, Colorado [abs.]: Geol. Soc. America Abs: with Programs, 89th Ann. Mtg., v. 8, no. 6, p. 956-957.

Knepper, D.H., Jr., 1974, Tectonic analysis of the Rio Grande rift zone: Colorado School Mines, Phd. Thesis T-1593.

1976, Late Cenozoic structure of the Rio Grande rift zone, central Colorado, in Epis, R.C., and Weimer, R.J., eds., Studies in Colorado field geology: Colorado School Mines Prof. Contr. 8, p. 421-430.

Knepper, D.H., Jr., and Grose, L.T., 1976, Structure, volcanism, and geothermal features of the northern Rio Grande rift zone, Colorado; in Epis, R.C., and Weimer, R.J., eds., Studies in Colorado field geology: Colorado School Mines Prof. Contr. 8, p. 403-420.

Lewis, E.L., 1966, The thermal springs of Colorado--A resource appraisa1: Univ. Colorado Dept. Geography, Master Sci. Thesis, 91 p. 
REFERENCES (Cont.)

Limbach, F.W., 1975, The geology of the Buena Vista area, Chaffee County, Colorado: Colorado School Mines Master Sci. Thesis, T-1692, 98 .p.

Lipman, P.W., 1968, Geology of the Summer Coon volcanic center, eastern San Juan Mountains, Colorado, in Epis, R.C., ed., Cenozoic volcanism in the southern Rocky Mountains: Colorado School Mines Quart., v. 63, no. 3, p. 211-236.

1975, Evolution of the Platoro Caldera complex and related volcanic rocks, southeastern San Juan Mountains, Colorado: U.S. Geol. Survey Paper 852, 128 p.

Lipman, P.W., Steven, T.A., and Mehnert, H.H., 1970, Volcanic history of the San Juan Mountains, Colorado, as indicated by potassium-argon dating: Ge01. Soc. America Bull., v. 81, p. 2329-2352.

Lovering, T.S., and Goddard, E.N., 1950, Geology and ore deposits of the Front Range, Colorado: U.S. Geol. Survey Prof. Paper 223, 319 p.

Luedke, R.G., Burbank, W.S., 1962, Geologic map of the Ouray quadrangle, Colorado: U.S. Geol. Survey Geol. Quad. Map GQ-192.

Mallory, E.C., Jr., and Barnett, P.R., 1973, Chemical and spectrochemical analyses of selected ground waters in Colorado: U.S. Geol. Survey open-file rept., $47 \mathrm{p}$.

McFarlane, A.C., 1961, Outline of the geology of the Cement Creek area, Gunnison County, Colorado, in Berg, R.R., and Rold, J.W., eds., Symposium on Lower and Middle Paleozoic rocks of Colorado- 12th Field Conf.: Rocky Mtn. Assoc. Geologists, p. 125-132.

Mertzman, S.A., Jr., 1971, The Summer Coon volcano, eastern San Juan Mountains, Colorado, in Guidebook of the San Luis basin, Colorado: New Mexico Geol. Soc. 22d Field Conference, p. 265-275.

Moench, R.H., and Drake, A.A., Jr., 1966, Economic geology of the Idaho Springs district, Clear Creek and Gilpin Counties, Colorado: U.S. Geol. Survey Bull. 1208, 19 p.

Moyer, J.L., Ansberry, L.E., Mallory, W.W., Loomis, F., and, Baars, D.L., 1961, Road 1og, in Berg, R.R., and Rold, J.W., eds., Symposium on Lower and Middle Paleozoic rocks of Colorado--12th Field Conf.: Rocky Mtn. Assoc. Geologists, p. 229-235.

Pear1, R.H., 1972, Geothermal resources of Colorado: Colorado Geol. Survey Spec. Pub. 2, 54 p.
Pratt, W.P., McKnight, E.T., and DeHon, R.A., 1969, Geologic map of the Rico quadrangle, Dolores and Montezuma Count ies, Colorado: U.S. Geol. Survey Geol. Quad. Map GQ-797.

Reed, M.J., 1975, Chemistry of thermal water in selected. geothermal areas of California: California Div. 011 and Gas Rept. TR 15.

Reiter, Marshal1, 1975, Terrestrial heat flow along the Rio Grande Rift, New Mexico and southern Colorado: Geol. Soc. America Bull., v. 86 , p. $811-818$.

Renner, J.L., White, D.E., and Williams, D.L., 1975, Hydrothermal convection systems, in Assessment of geothermal resources of the United States, 1975 U.S. Geol. Survey Circ. 726: p. 5-57.

Romero, John, and Fawcett, Donald, 1978, Geothermal resources of south-central Colorado and their relationship to ground and surface water: Colorado Div. of Water Resources, $127 \mathrm{p}$.

Samme1, E.A., 1979, Occurrence of low-temperature geothermal waters in the United States, in Assessment of geothermal resources of the United States--1978, L.J.P. Muffler, ed.: U.S. Geol. Survey Circ. 790 , p. 86-131.

Scott, G.R., 1964, Geologic map of the Northwest and Northeast Pueblo quadrangles, Colorado: U.S. Geol. Survey Misc. Geol. Inv. Map I-408.

1969, Geologic map of the Southwest and Southeast Pueblo quadrangles, Colorado: U.S. Geol. Survey Misc. Geol. Inv. Map I-597.

1973, Reconnaissance geologic map of the Owl Canyon quadrangle, Pueblo County, Colorado: U.S. Geol. Survey Misc. Field Studies Map MF-547.

1975, Reconnaissance geologic map of the Buena Vista quadrangle, Chaffee and Park Counties, Colorado: U.S. Geol. Survey Misc. Field Studies Map MF -657 (scale 1:62,500).

Scott, G.R., Taylor, R.M., Epis, R.C., and Wobus, R.A., 1976, Geologic map of the Pueblo $1^{\circ}$ $\times 2^{\circ}$ quadrangle, south-central Colorado: U.S. Geol. Survey Misc. Field Studies Map MF-775 (scale 1:187,500).

Scott, G.R., Van Alstine, R.E., and Sharp, W.N., 1975, Geologic map of the Poncha Springs quadrangle, Chaffee County, Colorado: U.S. Geol. Survey Misc. Field Studies Map MF-658 (scale 1:62,500).

Sears, J.D., 1924, Geology and oil and gas prospects of part of Moffat County, Colorado, and southern 
Sweetwater County, Wyoming: U.S. Geol. Survey Bul1. 751-G, p. 269-319.

Stark, J.T., and Behre, C.H., Jr., 1936, Tomichi dome flow: Geol. Soc. America Bull., v. 47, no. 1 , p. 101-110.

Steven, T.A., 1969a, Geologic map of the Bristol Head quadrangle, Mineral and Hinsdale Counties, Colorado: U.S. Geol. Survey Quad. Map GQ-631.

$1969 b$, Possible relation of mineralization to thermal springs in the creede-district, San Juan Mountains, Colorado: A discussion: Econ. Geol., v. 64, p. 696-698.

Steven, T.A., and Lipman, P.W., 1973, Geologic map of the Spar City quadrangle, Mineral County, Colorado: U.S. Geol. Survey Geol. Quad. Map GQ-1052.

Steven, T.A., and Ratte, J.C., 1960, Geology and ore deposits of the Sumitville district, San Juan Mountains, Colorado: U.S. Geol. Survey Prof. Paper 343, $70 \mathrm{p}$.

1973, Geologic map of the Creede quadrangle, Mineral and Saguache Counties, Colorado: U.S. Geol. Survey Geol. Quad. Map GQ-1053.

Steven, T.A., Lipman, P.W., Hail, W.J., Jr., Barker, F., and, Luedke, R.G., 1974, Geologic map of the Durango quadrangle, southwestern Colorado: U.S. Geol. Survey Misc. Field Geol. Inv. Map I-764.

Stoughton, Dean, 1977, Interpretation of seismic reflection data from the San Luis Valley, south- central Colorado: Colorado School Mines, Dept. Geophysical Engineering, Master Sci. Thesis T-1960, $100 \mathrm{p}$.

Taylor, R.B., and Scott, G.R., 1973, Reconnaissance geologic map of the Wetmore quadrangle, Custer and Pueblo Counties, Colorado: U.S. Geol. Survey Misc. Field Studies Map MF-548.

Taylor, R.B., Scott', G.R., and Wobus, R.A., 1975, Reconaissance geologic map of the Howard quadrangle, central Colorado: U.S. Geol. Survey Misc. Geol. Inv. Map I-892 (scale 1:62,500).

Taylor, R.B., Scott, G.R., Wobus, R.A., and Epis, R.C., 1975, Reconnaissance geologic map of the Royal Gorge quadrangle, Fremont and Custer Counties, Colorado: U.S. Geol. Survey Misc. Geol. Inv. Map I-869.

Truesdell, A.H., Fournier, R.0., and Thompson, J.M., 1973, Mixture, a computer program for the calculation of hot water temperature and mixing fractions of large volume warm springs of mixed water origin: Natl. Tech. Inf. Service Rept. PB-220 732, $12 \mathrm{p}$.

1975, Calculation of deep reservoir temperatures in geothermal systems from the chemistry of boiling spring development and use of geothermal resources: San Francisco, Cal ifornia, p. 837-844.

Tweto, 0gden, 1975, Preliminary geologic map of the Craig $1^{\circ} \times 2^{\circ}$ quadrangle, northwestern Colorado: U.S. Geol. Survey Misc. Field Studies Map MF-666 (Available as U.S.G.S. I-972).

1976, Preliminary geologic map of Colorado: U.S. Geol. Survey Misc. Field Studies Map MF-788.

Tweto, Ogden, Steven, T.A., Hail, W.J., and Moench, R.H., 1976, Preliminary geologic map of the Montrose $1^{\circ} \times 2^{\circ}$ quadrangle, southwestern Colorado: U.S. Geol. Survey Misc. Field Studies Map MF-761.

Van Alstine, R.E., 1970, Allochtonous Paleozoic blocks in the Tertiary San Luis-Upper Arkansas graben, Colorado, in Geological Survey Research 1970: U.S. Geo1. Survey Prof. Paper 700-B, $B-43-B 51$.

1974, Geology and mineral deposits of the Poncha Springs SE quadrangle, Chaffee County, Colorado: U.S. Geo1. Survey Prof. Paper 829, 17 p.

Van Alstine, R.E., and Cox, D.E., 1969, Fluorspar mines and prospects, in Geology and mineral deposits of the Poncha Springs NE quadrangle, Chaffee County, Colorado: U.S. Geol. Survey Prof. Paper 626, p. 38-43.

Vinckier, T.A., 1978, Hydrogeology of the Dakota Group aquifer with emphas is on the Radium-226 content of its contained ground water, Canon City Embayment, Fremont and Pueblo Counties, Colorado: Univ. Colorado, Dept. Geological Sciences, Master Sci. Thesis, $140 \mathrm{p}$.

Waring, G.A., 1965, Thermal springs of the United States and other countries of the world--A summary, revised by R.F. Bl ankenship and Ray Bental1: U.S. Geol. Survey Prof. Paper 492, 383 p.

Wehlage, E.F., 1976, The basics of applied geothermal engineering: West Covina, California: Geothermal Information Services, $211 \mathrm{p}$.

White, D.E., 1965, Geothermal energy: U.S. Geol. Survey Circ. 519, 17 p. 


\section{REFERENCES (Cont.)}

1972, Geochemistry applied to the discovery, evaluation, and exploitation of geothermal energy resources, in Proceedings of U.N. Symposium on the Development and Utilization of Geothermal Resources, Pisa: Geothermics Spec. Issue 2, v. 2, pt. 1 .
Zohdy, A.A.R., Hershey, L.A., Emery, P.A., and Stanley, W.D., 1971, Resistivity sections, upper Arkansas River Basin, Colorado: U.S. Geol. Survey open-file rept., 16 p. 


\section{COLORADO STRATIGRAPHIC CORRELATION CHART}

\section{COLORADO GEOLOGICAL SURVEY}

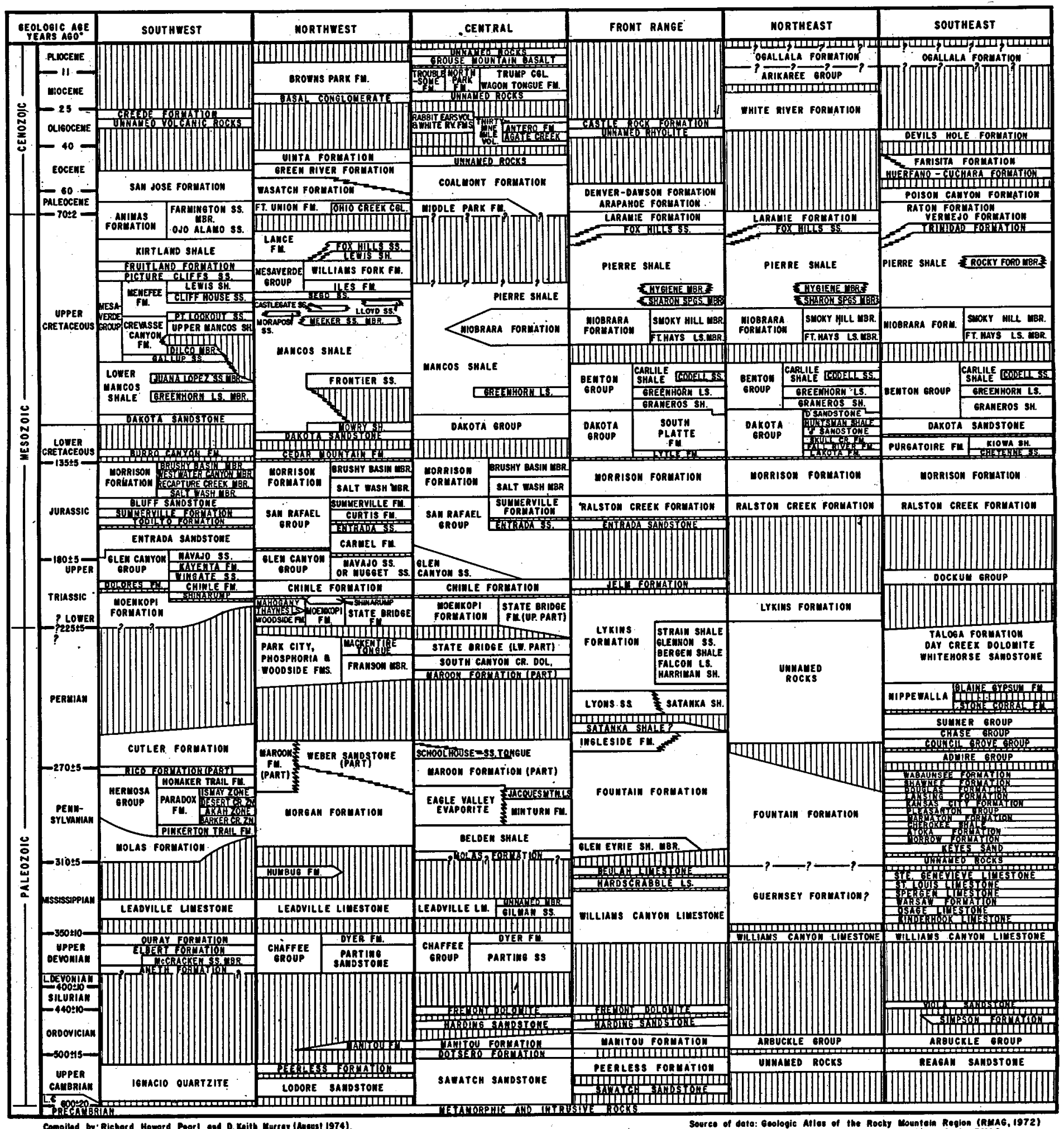

Compiliod by: Riehord Howord Poort out D. Keith Murray (Aupost 1974).

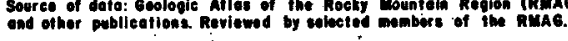


ENERGY-RELATED PUBLICATIONS OF THE COLORADO GEOLOGICAL SURVEY

GEOTHERMAL ENERGY AND GROUNDWATER

BULCETTN $33 .-$ Bibllography of Hydrogeologic Reports In Colorado, by R. H. Pearl, 1971,39 p., $\$ 1.00$.

BULLETIN 35 -.- Proceedings of a Sympostum on Geothermal Energy in Colorado, by R. H. Pearl, ed., 1974, $10<$ p., $\$ 3.00$.

BULLETIN 36 -- Geologic Control of Supply and Quality of Water in the Mountainous Part af Jefferson County. Colorado, by W. E. Hotstra and 0. C. Hat, , 1975, 5T p., \$3.00.

BULLETIN 39 -- An Appraisal of Colorado's Geothermal Resources, by J. K. Barrett and R. H. Pearl, 1978, $223 \mathrm{p} ., \$ 7.00$.

SPECIAL PUBLICATION 2 -- Geothermal Resources of Colorado, by R. H. Pear1, 1972,54 p., $\$ 1.00$.

SPECIAL PUBLICATION 4 - Geology of Ground Water Resources 12 Colorado-An Introduction, by R. H. Pearl, 1974, 47 p., $\$ 1.50$.

IMFORMATION SERIES 4 -.. Map Showing Thermal Springs, Hells and Heat-Flow Contours in Colorado, by J. K.

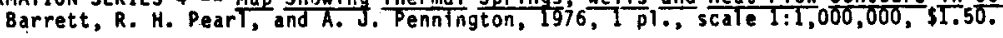

INFORMATION SERIES 6 -O Hydrogeological nata of Thermal Springs and Wells in Colorado, by J. K. Barrett and $\mathrm{K}$. H. Pearl, $1976,124 \mathrm{p} ., \$ 1.50$.

INFCRMATICN SERIES $\$$ - Geothermal Resource cevelopment in Colorado, Processes, Promises and Problems, by
B. A. Coe, $1978,48 \frac{\text { Re }}{0.00}$. RESOURCE SERIES 6 - Colorado's Hydrothermal Resource Base -- An Assessment, by R. H. Pearl, $1979, \$ 5.00$ URANIUM

BULLETIN 40 -. Radioact lye Mineral Occuirences of Colorado, and Blbliography, including maps, by J. L. Nelson-

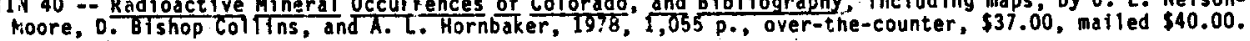

MAP SERIES 11 ... Urantum-Vanadium Mining Activity Map of Colorado with Directory, J. Collier, A. L. Hornbaker, and $\mathrm{W}$. Chenoweth, 1978, 5cale 1:500,000, inct. Uravan Minerat Area 1:100,000, \$4.00.

GENERAL

GEOLOGIC MAP OF COLORADO -- U.S. Geulogical Survey, 1935, 1 sheet, multf-colored, scale 1:500,000; reprinted by CoTorado Geological Survey, $1975, \$ 5.00$ ( $\$ 6.50$ rolled and malled).

MAP MF-788 -.. Preliminary Geologic Map of Colorado, compiled by Ogaran Tweto, published by U.S. Geological Survey, 1976, 2 sheets, black and white, scale $1: 500,000, \$ 1.50$.

MAP I-1039 -- Energy Résources Mas of Colorado, comptled by U.S. Geological Survey and Colorado Geological

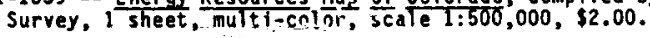

MAP SERIES 1 -- Geologic, Energy and Mineral Resources Maps of Routt County, Colorado, by A. E. M1ller, 1975, 2 maps, scale $1: 126,720, \$ 5.60$.

MAP SERIES 3 -- Geology of Giffot tounty, idy A. E. Miller, 1977, scale 1:126,720, \$8.00.

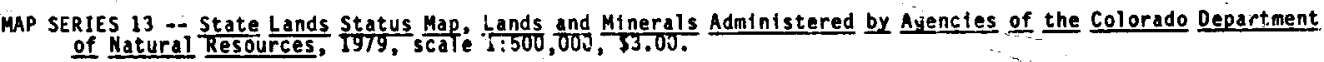

OPEN-FILE REPORT -- Mineral Resources Maps of Moffat County, Colorado, by C. S. Robinson and Associates, 1975,

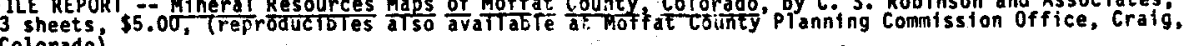
Colorado).

BULLETIK 37 -- Bibllography and Index of Colorado Geology $2815-1975$, complled by American Geological Institute, 1976, $\$ 7.50$ (soft cover) $\$ 10.00$ (hard cover) halt orders add $\$ 1.00$ for each copy, postage
and maller).

COLORADO STRATIGRAPHIC CORRELATION CHART - by R. H. Pearl and D. K. Murray, 1974, \$0.25.

RESOURCE SERIES 1 -- Geology of Rocky Mountain Coal, a Symposium, 1976, edited by D. Keith'Murray, 1977, 175 P., $\$ 4.00$.

RESOURCE SERIES 3 -- Colorado Coal Directory and Source Book, by L. C. Dawson and D. K. Murray, 1978,225 p., \$6.00.

RESOURCE SERIES 4 -- Proceedings of the Second Symposium on the Geology of Rocky Mountain Coal - 1977, edited by Helen E. Hodgson, 1978, $219 \frac{\text { the }}{\mathrm{p} .,} \frac{\text { Second }}{\$ 5.00}$

RESOURCE SERIES 5 -. Coal Resources of the Denver \& Cheyenne Basins, Colorado, by R. M. Kirkham \& L. R. Ladwig, 1979,70 p., 5 plates, over-the-counter $\$ 7.00 ;$ malled $\$ 8.00$.

RESOURCE SERIES 7 -- Evaluation of Cok1ng Coals in Colorado, by S. M. Goolsby, K. B. S. Reade, and D. K. Murray, $1979,80 \frac{\text { p., } 3 \text { plates, } \$ 7.00}{}$

INFORMATION SERIES 2 -- Coal Mines of Colorado, Statistical Data, by D. C. Jones and D. K. Murray, 1976, 27 P.. \$1.00.

INFORMATION SERIES 7 - Colorado Coal Analyses, 1975 (Analyses of 64 Samples Collected in 1975), by D. L. Boreck, D. C. Jones, D. K. Murray, J. E. Schuttz, and D. C. suek, 112 p., \$3.00.

INFORMATION SERIES 10 - Colorado Coal Analyses, 1976, by J. E. Schultz, 1978 (in preparation). SPECIAL PUBLICATION $9-1975$
D. K. Murray, 1978,17 Dummary of Coal Resources in Colorado, by A. L. Hornbaker, R. D. Holt, and

BULLETIK 34-A -- Btbliography. Coal Resources in Colorado, by R. D. Hoit, 1972, 32 p., \$1.00.

BULLETIN 41 - Blbliography and Index of Publications Related to Coal in Colorado, 1972-1977, by H. B. Fender, D. C. Jones, and D..K. Murray, 1978,55 p., $\$ 2.00$.

MAP SERIES 8 - Licensed Coal Mines in Colorado, by D. C. Jones, 1.977, scale 1:1,000,000, $\$ 2.00$.

MAP SERIES 9 -- Coal Resources and Devel opment Map of Colorado, by D. C. Jones, J. E. Schultz, and 0 . K. Murray, 1978, scale 1:500,000, $\$ 4.00$ (naTh orders add $\$ .50$ for each copy, postage and matler).

MAP SERIES 12 -. Map of L1censed Coal Mines in Colorado, as of June $1, \underline{1978, ~ S . ~ M . ~ G o o l s b y ~ a n d ~ K . ~ B . ~ S . ~ R e a d e, ~}$ 1978, sheet, scale $\frac{\text { a }}{1: 1,000,000,} \frac{\mathrm{T}}{\mathbf{2} .00}$

OPEN-FILE REPORT 78-2 -- Data Accumulation on the Methane Potent tal of the Coal Beds of Colorado, Final

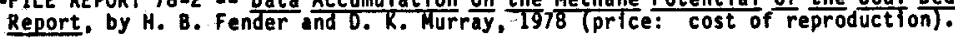

To order publications, specify serles and number, title, and quantity desired. Prepayment is required. Make checks payable to:

Colorado Geological Survey

Roon 715,1313 Sherman street

(Telephone: $303 / 839-2611$ ) 